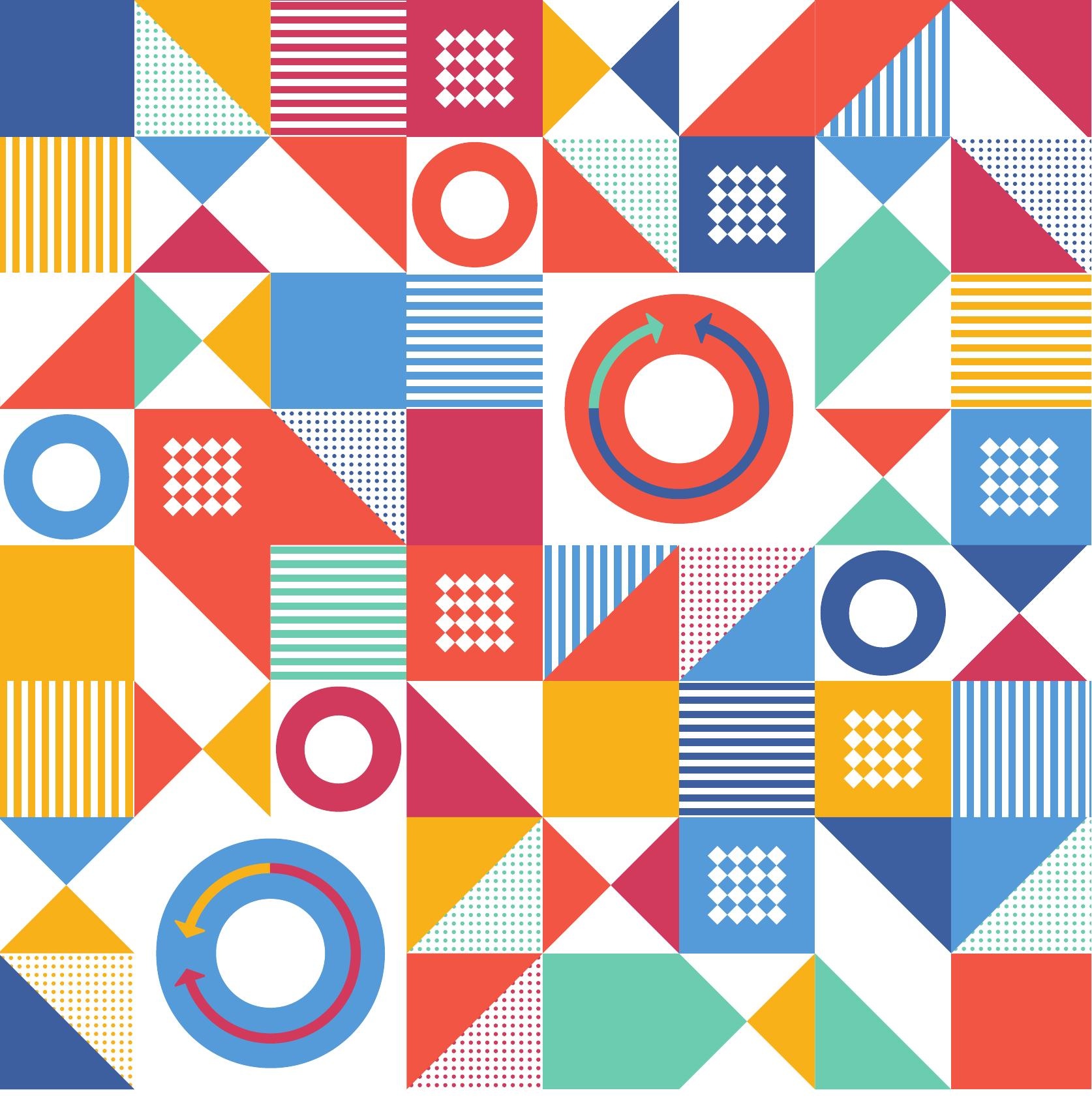

\title{
Managing Circular Building Projects
}



MANAGING CIRCULAR BUILDING PROJECTS

Marc van den Berg 



\title{
MANAGING CIRCULAR BUILDING PROJECTS
}

\author{
DISSERTATION
}

to obtain

the degree of doctor at the University of Twente, on the authority of the rector magnificus,

prof.dr. T.T.M. Palstra,

on account of the decision of the Doctorate Board,

to be publicly defended

on Thursday the $16^{\text {th }}$ of May 2019 at $14: 45$ hours

by

Marc Casper van den Berg

born on the $25^{\text {th }}$ of July 1989

in Zwolle, The Netherlands 
This dissertation has been approved by:

Prof.dr.ir. A.M. Adriaanse (supervisor)

Dr. J.T. Voordijk (supervisor)

Cover design: Pintip Vajarothai \& Marc van den Berg

Printed by: Ipskamp

ISBN: 978-90-365-4770-3

DOI: $10.3990 / 1.9789036547703$

(C) 2019 Enschede, The Netherlands. All rights reserved. No parts of this thesis may be reproduced, stored in a retrieval system or transmitted in any form or by any means without permission of the author. Alle rechten voorbehouden. Niets uit deze uitgave mag worden vermenigvuldigd, in enige vorm of op enige wijze, zonder voorafgaande schriftelijke toestemming van de auteur. 


\section{GRADUATION COMMITTEE:}

Chairman/secretary Prof.dr. G.P.M.R. Dewulf (University of Twente)

Supervisor

Prof.dr.ir. A.M. Adriaanse (University of Twente)

Supervisor

Dr. J.T. Voordijk (University of Twente)

Members

Prof.dr.ir. J.I.M. Halman (University of Twente)

Dr.ir. G.M. Bonnema (University of Twente)

Prof.dr. T. Hartmann (TU Berlin)

Prof.dr.ir. G.C.J.M. Vos (Tilburg University)

Prof.dr. D. Greenwood (Northumbria University) 
This research received funding from: the Twente Graduate School of the University of Twente for the proposal Using virtual worlds to support collaborative design in the AEC domain - a reflective cycle approach (2014 bridging grant); the NEVI Research Stichting for the proposal Professionalisering van inkoop- en toeleveringsprocessen via Bouw Informatie Modellen (BIM); the European Commission's TEMPUS IV program for the proposal Building Information Modeling: Integrated Design Environment for Engineering Education with submission number 543923-TEMPUS-1-2013-1-EG-TEMPUSJPCR; and the European Commission's Horizon 2020 research and innovation program for the proposal Buildings as Material Banks: Integrating Materials Passports with Reversible Building Design to Optimise Circular Industrial Value Chains with ID 642384-2. 


\section{Preface}

André Kuipers enjoyed looking out of the windows. On board the International Space Station, he had an unprecedented view of the earth. During his first journey into space, the Dutch astronaut observed "a tiny blue ball, shielded by the atmosphere that looks like a paper-thin, fluorescent layer" (Van Tongerloo, 2018). He also saw how precious our earth is, in particular when he looked at the deep and dark universe surrounding it. "I got a claustrophobic feeling from the view of my own planet. Then I realized: we only have that one blue ball. That is it." Other astronauts have made similar statements about changed perceptions of the planet after seeing it as a whole, free of national frontiers and impressed by its stunning beauty. The experience is so powerful that White (1998) termed it the "overview effect." That helps in realizing that natural resources are limited and action is needed to prevent expiry and all kinds of associated problems. This $\mathrm{PhD}$ thesis explores such action for the construction industry.

This is no rocket science, but down-to-earth research. I systematically observed, analyzed and documented actual building projects and the issues that demolition and design managers face in reducing, reusing and recycling building materials. The latter had turned out to be no straightforward matter at all, as evidenced by a 'failed' project covered by several Dutch news articles (see e.g. Borren, 2016; Muis, 2016). In 2008, a "flexible and modular" school building was designed to accommodate a gymnasium in Amsterdam for five to ten years. The explicit ambition here was to relocate the building after that period, but in 2016 it was demolished in traditional ways. Deconstructing and rebuilding appeared too complex: the modular system was out of fashion already, a key supplier had gone bankrupt and important (de)constructability knowledge thereby also got lost. I consider such issues as information challenges here. The remarkable story inspired me to study other building projects accordingly. I integrated six studies in which I describe, explain and (sometimes) predict what is going on in those projects from a variety of perspectives (yet none of outer space, unfortunately).

The integrated studies thereby provide some guidance for moving towards a circular built environment. Well ahead of his time, Boulding (1966) made a call for "the "spaceman" economy, in which the earth has become a single spaceship, without unlimited reservoirs of anything ... and in which, therefore, man must find his place in a cyclical ecological system which is capable of continuous reproduction of material form." The seminal idea of a new economic system resonates today as the "circular economy," which is defined by the Ellen MacArthur Foundation (2013) as "an industrial system that is restorative or regenerative by intention and design." Policy-makers, business leaders and academics, particularly in Europe and China, have popularized the concept of a 
circular economy as an alternative for our current, wasteful "linear" economy. The Netherlands, for example, aims to realize a circular economy by 2050 and set a $50 \%$ reduction of primary raw materials usage as an intermediate goal for 2030 (Dijksma \& Kamp, 2016). Given such (policy) goals, resource scarcity and the need to provide buildings and infrastructures at ever increasing speeds, the construction industry urgently needs a scientific knowledge base to implement circularity thinking in projects.

Managing circular building projects is, thus, becoming an obvious and imperative objective. This requires scientific endeavors, technical solutions and crossindustry collaborations for the years ahead. The journey will be complex, but worthwhile, since we are all astronauts on Spaceship Earth (see e.g. Koenen \& Kuipers, 2012; Rau \& Oberhuber, 2016, p. 51). This thesis is my modest contribution to that end.

Marc van den Berg

April 2019 


\section{Summary}

As the most resource intensive and wasteful industry, the construction sector is causing enormous socio-environmental problems. The root causes of these problems can be traced back to the way building projects are managed. Buildings are generally delivered as linear throwaway products, to be reduced to poorly recyclable waste when no longer needed. The latter is also happening at increasing pace, since buildings need to operate in ever complex and dynamic environments - while they are being designed and constructed as static structures. Previously developed remedies mainly targeted some socioenvironmental symptoms rather than these root causes. The concept of a circular economy, alternatively, poses that economic development and profitability are possible without continuously growing pressure on the environment through a combination of reduce, reuse and recycle activities. It is still unclear how the concept could be applied to manage building projects though. This paper-based thesis aims to provide some guidance to that end.

The main research goal is to develop actionable knowledge on managing circular building projects through exploring how information can be used to reduce, reuse and/or recycle building materials. It explicitly adopts the perspective of project management as challenges in (efficiently) using information. Construction managers, in this view, organize information to initiate and control material flows. Applying circularity thinking to this view then introduces a focus on enabling closed-loop material flows or, in other words, on maximizing reducing, reusing and recycling of building materials. Each of the chapters examines an essential, information intensive management task that contributes to one or more of these material strategies. The first three chapters do this from a demolition management perspective: they cover information usages for material recovery and reuse decisions (Chapter 1 ), subsequent coordination of demolition activities (Chapter 2) and the support of those activities with BIMbased methods (Chapter 3). The second three chapters do so from a design management perspective: they deal with information usages in generating reversible design proposals with BIM-based methods (Chapter 4), evaluating those proposals with a virtual reality-based method (Chapter 5) and a reflective serious gaming approach (Chapter 6). Different methodologies are adopted to provide a holistic understanding of essential management tasks during demolition and design, which are both conceptualized as part of a continuous cycle.

The first key insight that this thesis, accordingly, builds, is that demolition managers can enable closed-loop material flows through leveraging the information potentials of previous and later design stages. Information produced 
in a previous design stage, here called a priori design information, concerns any original representations and specifications of focal building materials; information produced in a later design stage, here called a posteriori design information, concerns any plans to reuse (or recycle) recovered building materials in the future. Demolition managers need to leverage the potentials of both types of design information to effectively close material loops. This key insight is mainly based on the related knowledge outputs of the first three chapters:

- Chapter 1 developed a general proposition for predicting whether (or not) a demolition contractor will recover any building objects. Based on ethnographic data on the use of information for such decisions, it is posed that any building object will be recovered for reuse only when the demolition contractor: (1) identifies an economic demand for the object; (2) distinguishes appropriate routines to disassemble it; and (3) can control the performance until integration in a new building.

- Chapter 2 provided an explanatory account on the coordination of demolition activities. The multiple-case study conceptualized demolition contractors as information processing systems facing uncertainty. It is concluded that demolition contractors need to take adequate organizational measures in response to specific levels of building, workflow and environmental uncertainty to effectively coordinate reuse or recycling of building materials.

- Chapter 3 reflected on three BIM uses to support deconstruction practices. Following an ethnographic-action research methodology, three new BIM uses were iteratively developed and implemented on site (contributing to reuse and recycling): '3D existing conditions analysis', 'reusable elements labeling' and ' $4 \mathrm{D}$ deconstruction simulation'.

The second key insight of this thesis is that design managers can, similarly, enable closed-loop material flows through leveraging the information potentials of previous and laterdemolition stages. Along the same lines as above, a distinction is made between respectively a priori demolition information, which concerns any specifications and representations of reusable building materials, and $a$ posterioridemolition information, which concerns any plans to facilitate recovery and subsequent reuse (or recycling) of materials in the future. Design managers can close material loops through leveraging the potentials of both types of demolition information. This insight is based on the related knowledge outputs of the second three chapters:

- Chapter 4 identified, classified and elaborated on BIM uses for reversible building design. Based on a case study, it is concluded that BIM-based methods differ in their potential to generate a reversible building design proposal - and to ease future reuse. 'Key' BIM uses are: design authoring, 3D coordination (clash detection) and drawing production. 'Viable' BIM uses are: 
quantity take-off (cost estimation) and design review. 'Negligible' BIM uses are: phase planning (4D simulation), code validation and engineering analyses.

- Chapter 5 proposed a virtual reality-based method to communicate design intent and feedback. Aligning expectations and solving design errors can help to reduce the use of building materials. The multiple-case study demonstrated that virtual reality environments provide benefits when used prior to designerclient review meetings in terms of: (1) exploration from a user perspective; (2) participation in solution-finding; and (3) feedback on a design proposal.

- Chapter 6 described a serious game design and its learning benefits. Based on game play sessions with students, it is concluded that serious games can contribute in experiential learning about construction supply chain management. Reflecting on the impacts of (circular) design decisions on later life-cycle stages contributes to reducing and reusing materials.

With these complementary insights, this paper-based thesis helps to rethink the way building projects can be managed. Material reduce, reuse and recycle activities are essential steps to move towards a healthier built environment that can regenerate itself time after time. Those activities can be managed through leveraging information potentials during demolition and design life-cycle stages. In circular building projects, those stages are part of a continuous cycle centered around buildings as material banks. Two key management strategies were derived to close material loops. Demolition managers need to use information from previous and later design stages; design managers similarly need to use information from previous and later demolition stages. These a priori and a posteriori information uses provide a hopeful and actionable response to many of the socio-environmental problems that can be attributed to today's construction industry. 


\section{Samenvatting}

De bouw gebruikt wereldwijd meer grondstoffen dan welke andere industrie dan ook en produceert bovendien het meeste afval. Daarmee is de sector verantwoordelijk voor steeds groter wordende sociaalecologische problemen. Als kernoorzaak van die problemen kan de manier waarop bouwprojecten worden gemanaged worden aangewezen: gebouwen worden over het algemeen opgeleverd als lineaire wegwerpproducten. Zodra die niet meer nodig zijn, worden ze gereduceerd tot afval dat bovendien lastig recyclebaar is. Dit alles gebeurt daarbij met toenemende snelheid, doordat gebouwen tegenwoordig moeten functioneren in omgevingen die steeds complexer en dynamischer worden - terwijl ze als statische bouwwerken worden ontworpen en gebouwd. In het verleden zijn vooral oplossingen ontwikkeld die achteraf als symptoombestrijding kunnen worden bestempeld. Het concept van de circulaire economie daarentegen stelt dat economische ontwikkeling en winsten mogelijk zijn door een combinatie van activiteiten gericht op het verminderen, hergebruiken en recyclen van materialen. Het is echter nog onduidelijk hoe dit concept kan worden toegepast bij het managen van bouwprojecten. Dit proefschrift bestaat daarom uit een serie papers die daar gezamenlijk richting aan proberen te geven.

Het onderzoek heeft als doelstelling om actiegerichte kennis te ontwikkelen voor het managen van circulaire bouwprojecten door te verkennen hoe informatie kan worden gebruikt om bouwmaterialen te verminderen, hergebruiken en/of recyclen. Projectmanagement wordt hier gezien als een uitdaging in het (efficiënt) organiseren van informatie. Bouwprojectmanagers gebruiken informatie om materiaalstromen te initiëren en te beheersen. Circulair denken introduceert daarbij een focus op het sluiten van materiaalkringlopen oftewel het nastreven van vermindering, hergebruik en recycling van bouwmaterialen. Elk van de volgende hoofdstukken behandelt daarom een essentiële, informatierijke managementtaak die bijdraagt aan een of meer van die materiaalstrategieën. De eerste drie hoofdstukken doen dit vanuit een sloopmanagementperspectief: deze behandelen informatiegebruik voor beslissingen met betrekking tot het al dan niet 'oogsten' van materiaal (Hoofdstuk 1), de daaropvolgende coördinatie van sloopactiviteiten (Hoofdstuk 2) en de ondersteuning van zulke activiteiten met methodes waarin bouwwerkinformatiemodellen (BIM) centraal staan (Hoofdstuk 3). De daaropvolgende drie hoofdstukken doen dit vanuit een ontwerpmanagementperspectief: deze behandelen informatiegebruik voor omkeerbaar ontwerpen met BIM-methodes (Hoofdstuk 4), het reviewen van ontwerpvoorstellen met een virtuele omgeving (Hoofdstuk 5) en een reflectieve 'serious gaming' benadering (Hoofdstuk 6). Verschillende methodologieën

vi | Samenvatting 
worden toegepast om een holistisch beeld te krijgen van essentiële managementtaken tijdens sloop en ontwerp, welke beide worden gezien als onderdeel van een doorlopende cyclus.

De eerste hoofdconclusie van dit proefschrift is dat sloopmanagers materiaalkringlopen kunnen sluiten door het benutten van informatiepotentieel uit voorgaande en opvolgende ontwerpfases. Informatie die geproduceerd is tijdens een voorgaande ontwerpfase, hier a priori ontwerpinformatie genoemd, betreft oorspronkelijke weergaven en specificaties van bouwmaterialen; informatie die geproduceerd wordt tijdens een opvolgende ontwerpfase, hier a posteriori ontwerpinformatie genoemd, betreft plannen om herwinnen en hergebruiken (of recyclen) van bouwmaterialen in de toekomst. Sloopmanagers zouden het potentieel van beide soorten ontwerpinformatie moeten benutten om effectief materiaalkringlopen te sluiten. Deze conclusie is gebaseerd op de inzichten uit met name de eerste drie hoofdstukken:

- Hoofdstuk 1 ontwikkelt een stelling waarmee kan worden voorspeld of een sloopaannemer wel of niet zal besluiten om bepaalde gebouwonderdelen te oogsten (voor hergebruik). Gebaseerd op etnografische data voor het gebruik van informatie voor zulke beslissingen, wordt er gesteld dat een sloopaannemer enkel en alleen een gebouwonderdeel zal oogsten wanneer die partij: (1) een economisch aantrekkelijke vraag ziet naar dat onderdeel; (2) geschikte demontagemethoden kan inzetten; en (3) het prestatieniveau kan handhaven tot het moment waarop het kan worden hergebruikt in een nieuw gebouw.

- Hoofdstuk 2 biedt een verklaring voor het effectief coördineren van sloopactiviteiten. De meervoudige casestudie beschouwt een sloopaannemer als een informatieverwerkingssysteem dat om moet gaan met allerlei onzekerheden. Er wordt geconcludeerd dat sloopaannemers passende maatregelen dienen te nemen als antwoord op specifieke niveaus van gebouw-, workflow- en omgevingsonzekerheden om effectief hergebruik of recycling van bouwmaterialen te coördineren.

- Hoofdstuk 3 reflecteert op drie BIM-toepassingen voor het ondersteunen van demontagewerkzaamheden. Op basis van een etnografisch-actieonderzoek zijn drie nieuwe BIM-toepassingen ontwikkeld en geïmplementeerd op de bouwplaats (en leveren daarmee een bijdrage aan hergebruik en recycling): '3D analyse bestaande situatie', 'codering herbruikbare elementen' en '4D demontagesimulatie'.

De tweede hoofdconclusie van dit proefschrift is dat ontwerpmanagers eveneens materiaalkringlopen kunnen sluiten door het benutten van informatiepotentieel uit voorgaande en opvolgende sloopfases. Net zoals hierboven beschreven, kan er een onderscheid gemaakt worden tussen a priori sloopinformatie, wat 
specificaties en weergaven van herbruikbare bouwmaterialen betreft, en $a$ posteriori sloopinformatie, wat plannen voor het faciliteren van het herwinnen en hergebruiken van bouwmaterialen in de toekomst betreft. Ontwerpmanagers kunnen materiaalkringlopen sluiten door het benutten van beide typen informatiepotentieel. Deze conclusie is gebaseerd op de inzichten uit de tweede drie hoofdstukken:

- Hoofdstuk 4 identificeert, classificeert en biedt een uitwerking van BIMtoepassingen voor omkeerbaar ontwerpen. Op basis van een casestudie, wordt er geconcludeerd dat BIM-toepassingen verschillen in de mate waarop zij omkeerbaar ontwerpen - en dus toekomstig hergebruik - kunnen ondersteunen. 'Essentiële' BIM-toepassingen voor omkeerbaar ontwerpen zijn: ontwerpend modeleren, 3D coördinatie (clashdetectie) en productie van tekeningen. 'Bruikbare' BIM-toepassingen zijn: hoeveelhedenextractie (kostenbepaling) en ontwerpreview. 'Onbeduidende' BIM-toepassingen zijn: planning (4D simulatie), validatie bouwbesluit en engineering analyses.

- Hoofdstuk 5 presenteert een 'virtual reality'-methode voor het communiceren van ontwerpvoorstellen en feedback tussen ontwerpers en opdrachtgevers. Het op één lijn brengen van verwachtingen en het gezamenlijk oplossen van ontwerpfouten kan leiden tot een reductie in bouwmaterialen. De meervoudige casestudie toont in dat opzicht aan dat het gebruik virtuele omgevingen voordelen kunnen bieden ten aanzien van: (1) verkenningen vanuit gebruikersperspectief; (2) betrokkenheid bij het vinden van ontwerpoplossingen; en (3) feedback op een ontwerpvoorstel.

- Hoofdstuk 6 beschrijft het ontwerp van een 'serious game' en zijn leereffecten. Op basis van speelsessies met studenten, wordt er geconcludeerd dat 'serious games' een bijdrage kunnen leveren aan het ervaringsgericht leren over bouwketenmanagement. Reflecteren op de impact die (circulaire) ontwerpbeslissingen hebben op latere levenscyclifasen draagt bij aan het verminderen en het hergebruiken van materialen.

Met deze complementaire inzichten helpt dit (op papers gebaseerde) proefschrift bij het omdenken van de manier waarop bouwprojecten kunnen worden gemanaged. Het verminderen, hergebruiken en recyclen van bouwmaterialen zijn noodzakelijke activiteiten op weg naar een gezondere gebouwde omgeving die zichzelf steeds opnieuw kan herstellen. Die activiteiten kunnen worden gemanaged door het beschikbare informatiepotentieel te benutten zowel tijdens de sloop als tijdens het ontwerp. Die twee fasen zijn bij circulaire bouwprojecten onderdeel van een doorlopende cyclus waarbij gebouwen als materialenbanken moeten worden gezien. In dit proefschrift werden zo twee hoofdconclusies geformuleerd voor het sluiten van materiaalkringlopen. Sloopmanagers dienen informatie van voorgaande en opvolgende ontwerpfases te benutten; ontwerpmanagers dienen informatie van viii | Samenvatting 
voorgaande en opvolgende sloopfases te benutten. Het gebruik van a priori en a posteriori informatiepotentieel biedt zo een hoopvol en actiegericht antwoord op de vele sociaalecologische problemen waar de bouw op dit moment mee te maken heeft. 


\section{Table of contents}

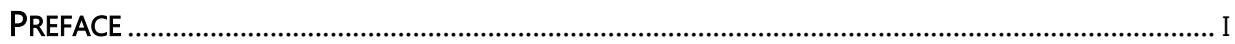

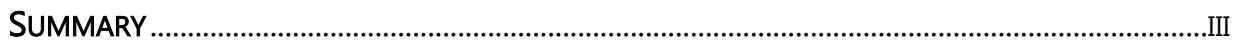

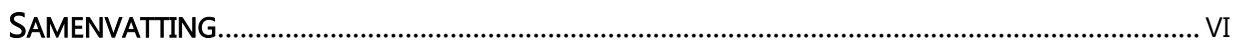

INTRODUCTION ...............................................................................................................

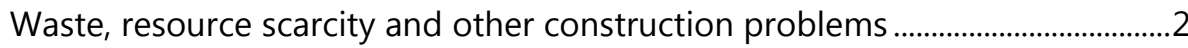

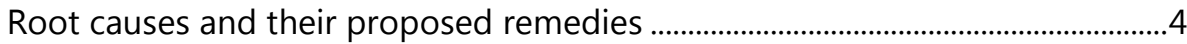

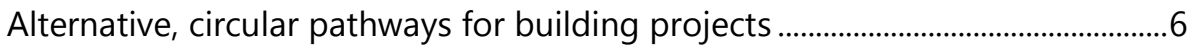

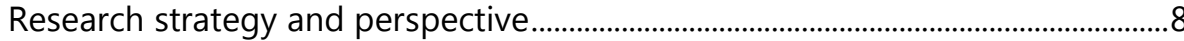

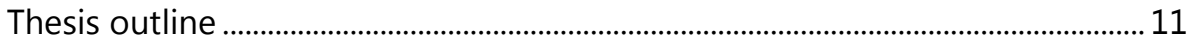

\section{CHAPTER 1}

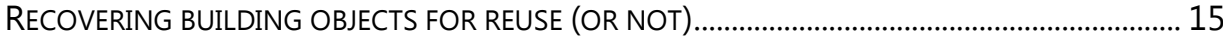

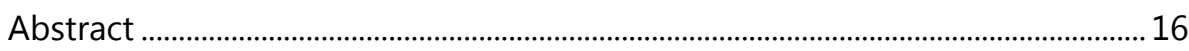

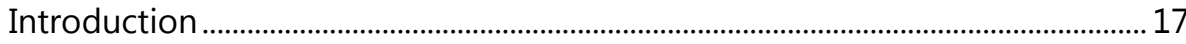

Literature review - object recovery and reuse in a circular economy ................. 18

- Circular economy research for buildings ................................................................... 19

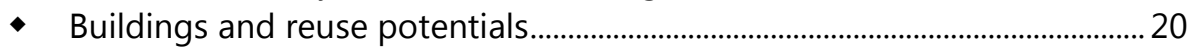

- Reuse enabling recovery practices .............................................................................. 21

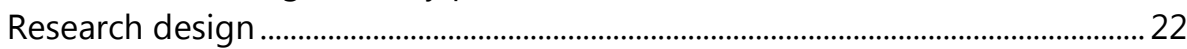

- Ethnographic observations, interviews and documents ...................................22

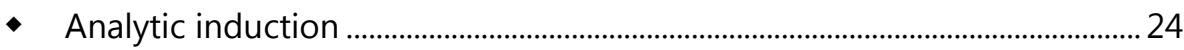

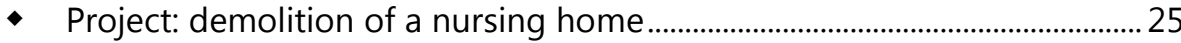

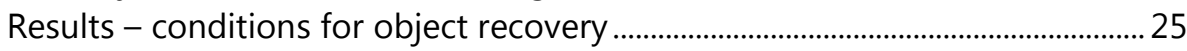

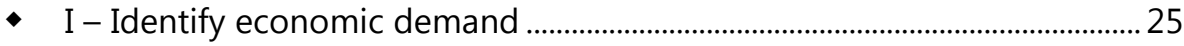

- II - Distinguish disassembly routines ........................................................................... 28

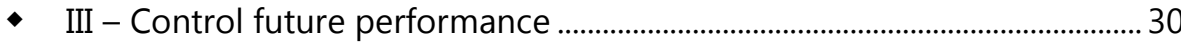

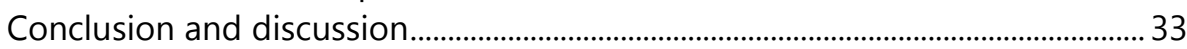

- Recovery - if all conditions are satisfied ................................................................. 33

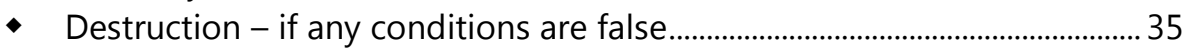

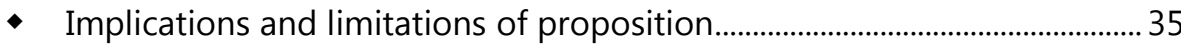

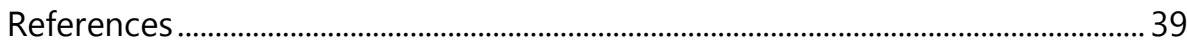

\section{CHAPTER 2}

INFORMATION PROCESSING FOR END-OF-LIFE COORDINATION: A MULTIPLE-CASE STUDY..... 43

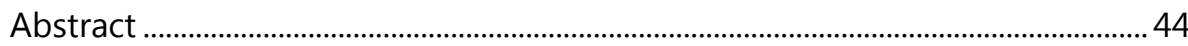

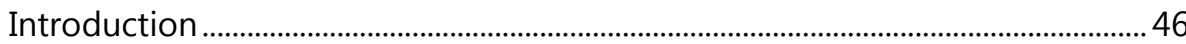

$\mathrm{x}$ | Table of contents 


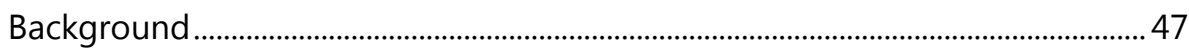

- Empirical knowledge on end-of-life coordination............................................47

- Theoretical knowledge on information processing .............................................50

Research design ............................................................................................................. 52

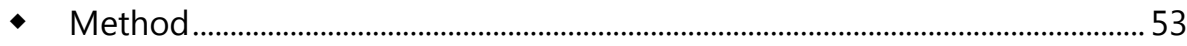

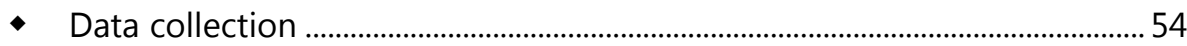

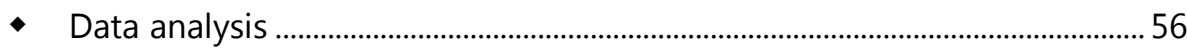

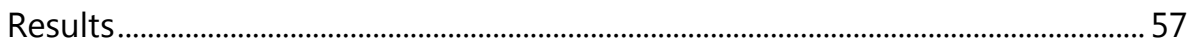

- Case I: material recycling (faculty building) .....................................................5

- Case II: component reuse (nursing home) …………………………………......59

- Case III: element reuse (psychiatric hospital) ........................................................6 60

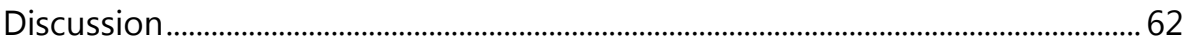

- Contributions: uncertainties, organizational responses and their (mis)matches for three end-of-life strategies ................................................... 62

- Scientific and practical implications......................................................................68

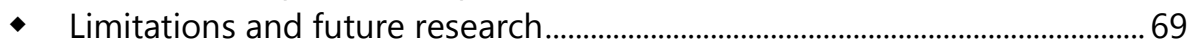

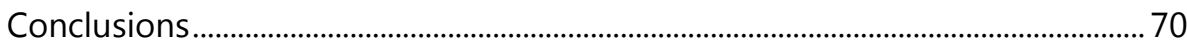

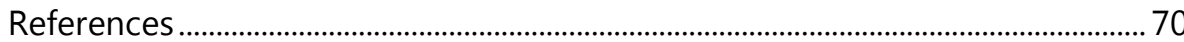

\section{CHAPTER 3}

BIM USES FOR DECONSTRUCTION PRACTICES: THREE ETHNOGRAPHIC-ACTION INSIGHTS ...... 77

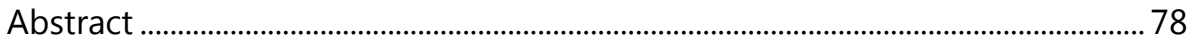

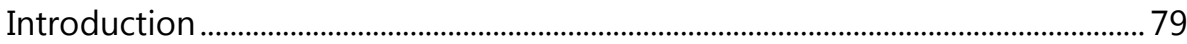

Review on leveraging BIM for deconstruction........................................................... 80

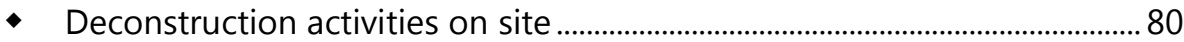

- Potentials of BIM-based methods......................................................................... 82

Ethnographic-action research methodology........................................................... 84

Results: BIM uses for deconstruction ....................................................................... 86

- BIM use I: 3D existing conditions analysis............................................................8

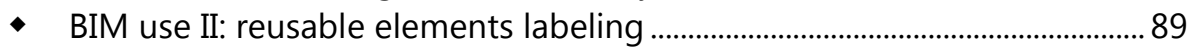

- BIM use III: 4D deconstruction simulation …………………………………….....92

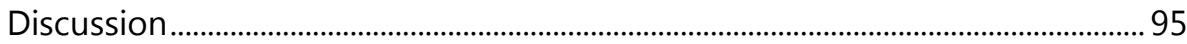

- Contributions: three ethnographic-action insights for deconstruction....95

- Implications and limitations of BIM uses ..........................................................96

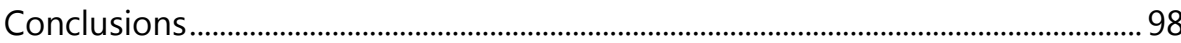

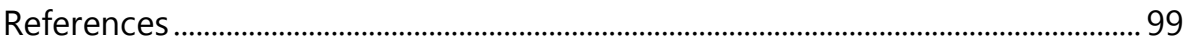




\section{CHAPTER 4}

BIM USES FOR REVERSIBLE BUILDING DESIGN: IDENTIFICATION, CLASSIFICATION \& ELABORATION 103

Abstract .104

Introduction .105

Theoretical framework 106

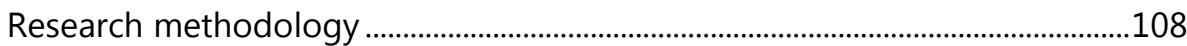

Results 109

Discussion .112

- Theoretical and practical contributions .113

- Limitations and further research .114

Conclusion .114

Acknowledgements .115

References

\section{CHAPTER 5}

SUPPORTING DESIGN REVIEWS WITH PRE-MEETING VIRTUAL REALITY ENVIRONMENTS ...........117

Abstract

Introduction

Theoretical framework

- Exploration from a user perspective ......................................................................123

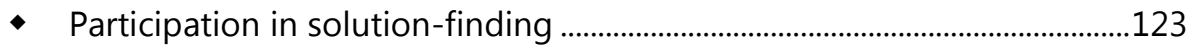

- Feedback on a design proposal ............................................................................124

Research methodology ..................................................................................................125

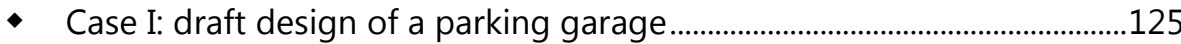

- Case II: definitive design of water production plants ......................................126

- Data collection: using multiple sources from case studies.............................126

- Data analysis: applying a pattern-matching strategy ......................................127

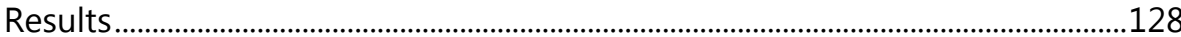

- Exploration from a user perspective ................................................................128

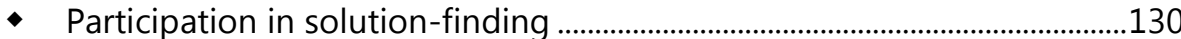

- Feedback on a design proposal .......................................................................132

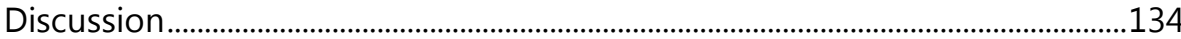

- Contributions: insights and recommendations from pattern-matching 134

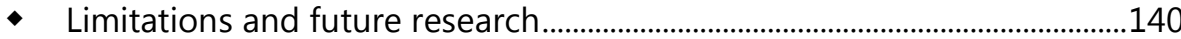

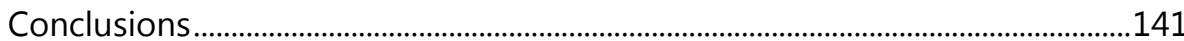

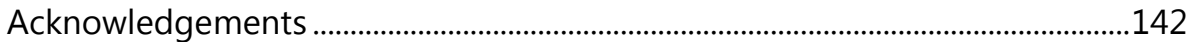

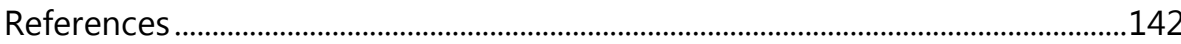




\section{CHAPTER 6}

EXPERIENCING SUPPLY CHAIN OPTIMIZATIONS: A SERIOUS GAMING APPROACH

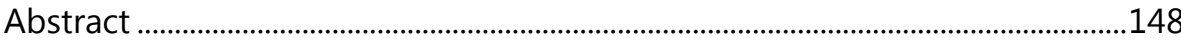

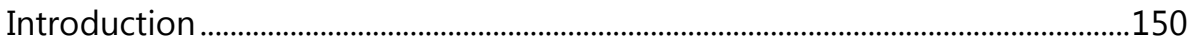

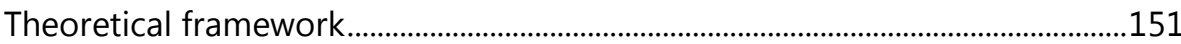

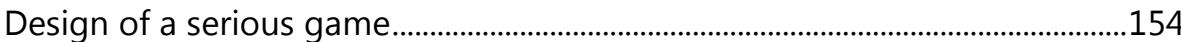

- Step 1 - Prototyping: integrating worlds of Reality, Meaning and Play 155

- Step 2 - Testing and evaluating: play-testing prototypical serious game in workshop

- Step 3 - Redesigning: incorporating feedback into final serious game version

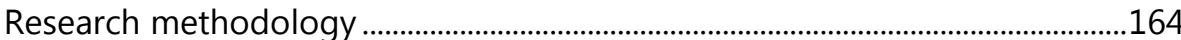

- Collecting data: play sessions during master's course .....................................165

- Analyzing data: content analysis of reports and pictures ..............................166

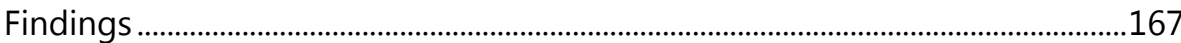

- Hypothesis 1: supply chain improvement through coordinating design and construction tasks coherently

- Hypothesis 2: supply chain improvement through taking constructability aspects into account when designing

- Hypothesis 3: supply chain improvement through continuously balancing scope, time and cost throughout a project ....................................................172

Discussion

- Experiencing supply chain optimizations: evidence for three hypotheses

- Limitations and directions for future research ..................................................176

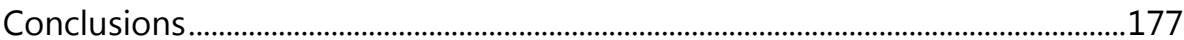

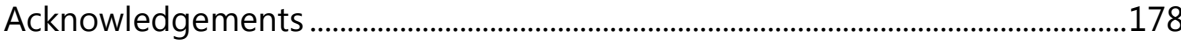

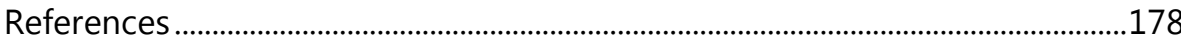

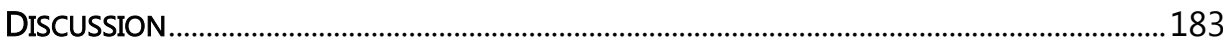

Theoretical contributions to demolition management ..........................................184

- 1. A proposition for predicting building object recovery...............................185

- 2. Uncertainties and coordination mechanisms to explain end-of-life

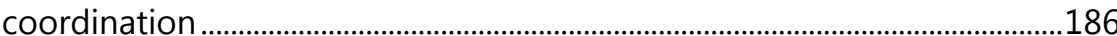

- 3. BIM uses for deconstruction practices.........................................................187

Theoretical contributions to design management................................................189

- 4. BIM uses for reversible building design ........................................................190

- 5. Systematic reflection on pre-meeting virtual reality environments for design review 
- 6. A serious gaming approach for construction supply chain management

Practical contributions ...................................................................................................193

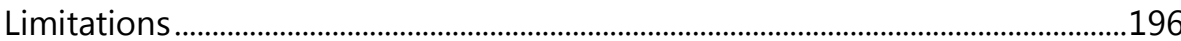

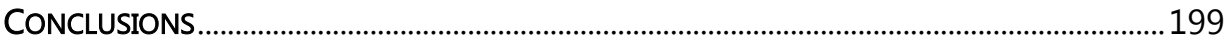

Demolition management for closing material loops .............................................200

Design management for closing material loops.......................................................201

Outlook and recommendations.....................................................................................202

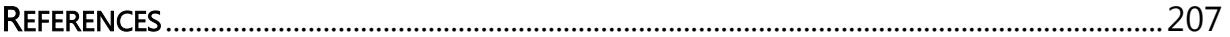

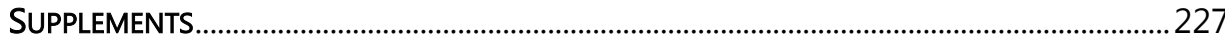

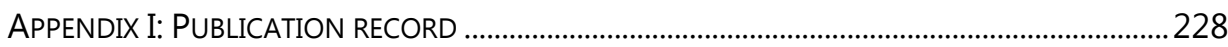

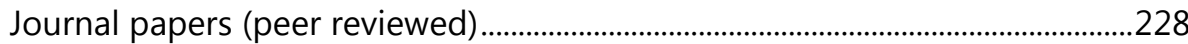

Scientific conference papers (peer reviewed) …………………………………….....228

APPENDIX II: COMPLEMENTARY RESEARCH WORK .......................................................................229

I: Circularity challenges and solutions in a design project (ongoing)...............229

II: Relative learning benefits of serious games for construction supply chain

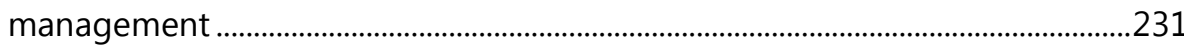

III: Designing Things to explore controversies.........................................................233

IV: BIM solutions for integrated project management of reversible buildings 235

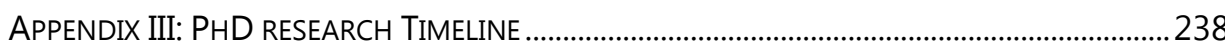

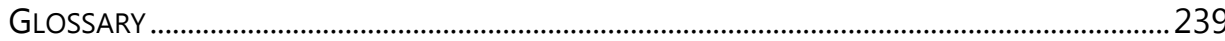

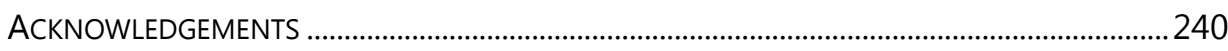

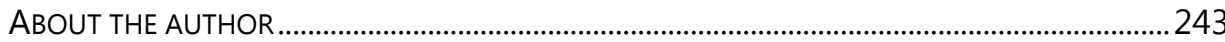




\section{Introduction}




\section{Introduction}

It is time to rethink the way building projects are managed. This $\mathrm{PhD}$ thesis points to fundamental flaws in our built environment and society at large. Buildings are usually designed as permanent structures, but then quickly turned into waste when no longer needed. This causes enormous socio-environmental problems that are becoming increasingly visible. A response is provided here through the adoption of circularity thinking and conceptualizing buildings as material banks. This research examines demolition and design management as challenges in using information. Six complementary studies are, accordingly, presented that deal with essential management activities to reduce production and consumption, reuse materials for the same (or a slightly different) purpose and/or recycle waste into substitutes for raw materials. Altogether, these studies offer a base for two key insights to enable closed-loop material flows in construction.

\section{Waste, resource scarcity and other construction problems}

The construction industry is vital to creating physical assets that shape our lives in unique ways. Both the act and the result of building are major sources of social and economic change. The industry is the principal force in the dynamics of cities and change in the built environment, responsible for generating around half of all physical assets in society (Winch, 2010). It accounts for around 6\% of the global GDP and provides jobs to more than 100 million people worldwide (De Almeida, Bühler, Gerbert, Castagnino, \& Rothballer, 2016). The homes, workplaces and infrastructure that the construction industry generates can be exploited to achieve social and economic ends. Buildings and other assets have a major impact on the standards of health and well-being of their users. Their importance goes beyond practical needs though and extends to cultural aspects of society as well (Koutamanis, Van Reijn, \& Van Bueren, 2018). With good feeling for drama, Brand (1994, p. 2) states that they "contain our lives and civilization." As such, the construction industry can provide benefits to the lives of almost everyone. But there is also another side.

The industry produces significant amounts of construction and demolition waste (C\&DW). In many countries, the waste from construction and demolition activities represents the largest single waste stream (Cheshire, 2016). In the United States, for example, this is around $40 \%$ of all solid waste generated annually (De Almeida et al., 2016). European construction and demolition waste comprises 820 million tons per year, which is equivalent to around $46 \%$ of the total amount of waste generated (Gálvez-Martos, Styles, Schoenberger, \& 
Zeschmar-Lahl, 2018). The waste stream is relatively heterogeneous and includes materials like concrete, bricks, masonry, gypsum, tiles, wood, glass, metals, plastic and asbestos. The exact composition depends on the generation phase, original function and location (Lansink, 2017, p. 193). Most waste originates from demolition and other end-of-life activities though (Akanbi et al., 2018; Kibert, 2016; Koutamanis et al., 2018). A small part of the waste stream contains hazardous materials, like asbestos, which have harmful impacts on the human health and nature if they are not disposed of properly. The largest part comprises inert materials, which lack chemical reactivity at ambient conditions $(\mathrm{Wu}, \mathrm{Yu}$, Shen, \& Liu, 2014). Despite this relatively high inert fraction and the rather low specific environmental impact (per $\mathrm{Mg}$ ) of construction and demolition waste, the large volumes generated have high associated environmental impacts, mostly derived from logistics and land occupation (Gálvez-Martos et al., 2018).

The construction industry is also the largest consumer of natural resources (Iacovidou \& Purnell, 2016). It is estimated that the built environment demands approximately $40 \%$ of all materials extracted from nature (Cheshire, 2016). Construction and engineering materials originate from oil (polymers), ores (metals and ceramics) and biomass (timer and paper) (Allwood, Ashby, Gutowski, $\&$ Worrell, 2011). Oils and ores are non-renewable. Geologically scarce resources (e.g. antimony, molybdenum and zinc) may be exhausted within several decades if no (policy) measures are taken: Henckens, Van Ierland, Driessen, and Worrell (2016) argue that market price mechanisms are unlikely to provide advance warning of exhaustion. Gordon, Bertram, and Graedel (2006) estimated that around $26 \%$ of the extractable copper and $19 \%$ of the zinc is already lost in landfills as non-recycled waste. Most raw materials of concrete are generally abundantly available and found locally worldwide though, but some materials such as natural sand and limestone suffer local scarcity (Thelen et al., 2018). The construction industry's steel demand is about half of the total global production (De Almeida et al., 2016). Raw material extraction and production put strain on the environment as ecosystems are exploited. Deforestation, for example, can cause biodiversity loss, soil erosion and desertification (Kibert, 2016, p. 66). Closely related, the construction industry is also responsible for one third of the total global energy consumption and the associated emissions (Iacovidou $\&$ Purnell, 2016; Ness, Swift, Ranasinghe, Xing, \& Soebarto, 2015).

Resource scarcity and waste generation are not only environmental but also social problems. Construction and demolition waste is traditionally disposed of in landfills. This causes, for example, space concerns in densely populated nations and can contaminate surrounding water bodies with toxic chemicals used in buildings (Cooper \& Gutowski, 2015). The impact of scarcity differs from resource to resource, but typically influences the economic viability and in extreme cases 
whether certain products can be produced or not (Andrews, 2015). A society that depends on finite resources is always in danger of consuming all of its resources. Volatility of material or energy prices can create a politically unstable world (Esposito, Tse, \& Soufani, 2017). Resource depletion may account for the collapse of entire civilizations (Allwood et al., 2011). Diamond (2011) explains, for example, how the overuse of wood products eventually destroyed the survival prospects of the inhabitants of Easter Island. Thackara (2015) adds that this "lesson applies equally to us today." The lust to control resources, like oil, have already caused wars and it is possible that the control of fresh water supply will lead to further conflicts in the near future (Andrews, 2015). The environmental problems so inherent to the practices of the construction industry are, hence, closely related to social problems in the here and now.

\section{Root causes and their proposed remedies}

How did we end up in this mess? The root cause of the socio-environmental problems that are becoming increasingly visible can be found in the altered relationship between individuals and the material world since the industrial revolution. Until the late $19^{\text {th }}$ century, products and services were created through hand production methods and craftsmanship. Waste as unwanted or unusable materials was virtually unknown with a "stewardship of objects" as the prevailing practice (Lieder \& Rashid, 2016). This completely changed with the introduction of new technologies, manufacturing processes and other innovations that enabled (early) mass production. Standardization and industrialization of the production process made it possible to produce higher volumes of products and at lower prices (Gort, 2015, pp. 10-11). Production rates and personal wealth accordingly multiplied with a reinforcing demand-supplyincome cycle. The mantra became 'the more of each, the better'. Companies extracted natural resources and used energy to convert them into products that were purchased and eventually disposed of (Crainer, 2013). Manufacturers later explicitly started to plan for obsolescence, for example through introducing frequent and cosmetic changes or reducing the technical working life of products (like light bulbs or nylon stockings) (Andrews, 2015; Rau \& Oberhuber, 2016). The linear pattern of take-make-dispose made economic sense under the assumption of plentiful and a continuing supply of raw materials.

That assumption has turned out to be wrong. For buildings, the situation is arguably worse as they are typically conceived as permanent structures, while they may be subject to structural, spatial and material transformations (Durmisevic, 2006). The seminal work of Brand (1994) describes how buildings always change, however poorly, after they have been built: commercial buildings

4 | Introduction 
constantly need to adapt because of competitive pressures; domestic buildings respond directly to a family's ideas, annoyances and growth prospects; and institutional buildings seem mortified to change in attempting to convey timeless reliability. Latour and Yaneva (2008) similarly state that a building is not a static object: "it ages, it is transformed by its users, modified by all of what happens inside and outside and ... it will pass or be renovated, adulterated and transformed beyond recognition." But most buildings are not designed and constructed to accommodate such transformations. Instead, they combine huge reservoirs of materials and components in ever more complex ways, which makes their assembly and disassembly difficult to achieve (Gorgolewski, 2008). Architects and builders imagine their creations as permanent and "no designer intends on spending intensive labor creating a building only to be torn down" (Kibert, Chini, \& Languell, 2001). When building owners or users have changing use requirements that the building cannot accommodate, the facility's fate is usually demolition with no (or little) attempts to recover value. The throwaway mindset and the poor adaptability of buildings have both resulted in typical onedirectional material flows: from raw material extraction, construction and use to landfills.

Starting in the second half of the $20^{\text {th }}$ century, awareness of the environmental limits of our planet resulted in several theoretic concepts and initiatives. The publication Limits to Growth concluded that resources were used beyond the carrying capacity of the planet (Meadows, Meadows, Randers, \& Behrens, 1972). Brundtland et al. (1987) articulated a link between economic efficiency and environmental capacity in their report Our Common Future and called for sustainable development "that meets the needs of the present without compromising the ability of future generations to meet their own needs." Governments around the world successively started to adopt diverse waste reduction and recycling programs to encourage a better use and conservation of resources (Ghisellini, Cialani, \& Ulgiati, 2016). In the Netherlands, following a parliamentary proposal in 1979, a "waste hierarchy" was developed with a preference order for waste management: from prevention, via source separation, reuse of products, recycling of materials, useful incineration with winning of energy to functional landfilling (Lansink, 2017; Parto, Loorbach, Lansink, \& Kemp, 2007). Frosch and Gallopoulos (1989) later introduced the view of material, energy and information as flows of resources and promoted the idea that "wastes from one industrial process can serve as raw materials for another." Their idea that the industrial ecosystem could function as an analogue of the biological ecosystem resurfaced later as biomimicry (Benyus, 1997), which refers to design inspired by nature. McDonough and Braungart $(1998,2002)$ subsequently proposed a cradle-to-cradle design framework that follows nature's model of 
eco-effectiveness, thereby separating between biological nutrients (natural materials that can biodegrade safely) and technical nutrients (manmade materials that can be reused). The shared principles of these different remedies lie in increasing resource efficiency, though most seem to target the symptoms of the socio-environmental problems rather than root causes.

\section{Alternative, circular pathways for building projects}

More systemic changes are necessary to optimize buildings for multiple cycles of disassembly and reuse. To that end, the concept of a circular economy has recently gained traction as it suggests that economic development and profitability is possible without an ever-growing pressure on the environment (Ghisellini et al., 2016; Kalmykova, Sadagopan, \& Rosado, 2018). A circular economy is an industrial system that is restorative by intent (Ellen MacArthur Foundation, 2013). It positions economic activities within an alternative flow model, one that is cyclical rather than linear (Korhonen, Honkasalo, \& Seppälä, 2018). Although this is often simply "depicted as a combination of reduce, reuse and recycle activities" (Kirchherr, Reike, \& Hekkert, 2017), its three principles are more fundamental. First, it aims to design out waste throughout the various lifecycles and uses of products; not only from manufacturing processes as lean management aspires to do (Nguyen, Stuchtey, \& Zils, 2014). Second, like the cradle-to-cradle approach, it distinguishes between biological (consumable) components - which can be returned to the biosphere, either directly or through a cascade of cycles - and technical (durable) components - which can remain in industrial cycles. Third, it proposes that the energy required to fuel the industrial cycles should be renewable. These principles have been translated into four alternative - value propositions (Ellen MacArthur Foundation, 2013) that Cheshire (2016) applied to buildings: minimizing material usage (refurbishing rather than demolishing and rebuilding); maximizing the number of consecutive cycles (refurbishing, adapting and refitting longer); diversifying reuse across industries (replacing virgin materials with waste from other industries); and avoiding contaminated materials (keeping materials pure and allowing them to be reused, recycled or composted at end-of-life). Through fundamentally rethinking these material flows, circularity moves from eco-efficiency (doing less bad) to ecoeffectiveness (doing better) (McDonough \& Braungart, 2010; Pomponi \& Moncaster, 2017).

It is still unclear how this circularity thinking can be applied to manage building projects though. Several studies have started to problematize the transition towards circular construction practices through mapping all kinds of barriers. The lack of coordinated construction supply chains, for example, limits a consistent 6 | Introduction 
supply of reusable building components (Gorgolewski, 2008). Other industryspecific issues relate to the large sizes of salvaged items, the lack of standards, codes and guidelines and the uniqueness of buildings (Hosseini, Chileshe, Rameezdeen, \& Lehmann, 2014; Hosseini, Rameezdeen, Chileshe, \& Lehmann, 2015; Iacovidou \& Purnell, 2016). Exemplary organizational issues include extra time and efforts in sorting, transporting and recovering processes (Mahpour, 2018) and the higher associated labor costs (Coelho \& De Brito, 2013b). Another stream of literature aims to guide the transition to a circular economy through traditional quantitative instruments (e.g. Life Cycle Analyses) (Merli, Preziosi, \& Acampora, 2018). The systematic analysis of best (management) practices lacks behind though. Leising, Quist, and Bocken (2018), as one of the few, investigated supply chain coordination in circular buildings and concluded that new types of business models and a new process design are required for the construction sector - yet admit that their work is mostly descriptive and that further development is necessary to examine patterns and mechanisms at hand. Most circular economy studies are furthermore devoted to the manufacturing industries (Adams, Osmani, Thorpe, \& Thornback, 2017) and are similarly of limited value to guide circular building projects.

Managing such projects can be conceptualized as the organization of information to initiate and control (circular) material flows (Winch, 2010, 2015). Like any organization, construction firms must monitor their environment, take decisions, communicate intentions and ensure that what they intended to happen does happen. Such management activities require the use of information, referred to as "data which are relevant, accurate, timely and concise" (Tushman \& Nadler, 1978, p. 614). Today's management activities are often supported with digital tools and technologies that provide more efficient ways to process information. The dominant digital technology in construction research and application is Building Information Modeling (BIM), which pursues the "ideal of having a complete, coherent, true digital representation of buildings" (Turk, 2016). Those representations (called BIM models) can be produced, communicated and analyzed over different life-cycle stages (Eastman, Teicholz, Sacks, \& Liston, 2011; Succar, 2009) and, as such, bring benefits to the management of projects (Bryde, Broquetas, \& Volm, 2013). BIM research for environmental sustainability has proliferated in recent years, but studies primarily dealt with energy efficiency issues during design and construction stages (Volk, Stengel, \& Schultmann, 2014; Wong \& Zhou, 2015). The use of (digital) information to achieve closed-loop material flows is understudied though. While theoretical advancements have been made with design for disassembly principles (Crowther, 1999; Durmisevic, 2006), materials hidden in existing buildings are still rarely considered as attractive alternatives to raw ones 
(Koutamanis et al., 2018). There are, accordingly, limited reflections on actual management activities for closing material loops - and on the potential of digital technologies, like BIM, to support those activities. This points to a clear need for detailed and holistic studies on the managerial use of information to reduce, reuse and/or recycle materials.

Summarizing, there is a lack of scientific knowledge for managing circular building projects. Buildings are typically conceived as static structures, while they constantly face structural, spatial and material transformations. The structures are also products of a throw-away society: buildings are usually reduced to poorly recyclable waste when they are no longer needed. These systemic faults result in huge amounts of construction and demolition waste, pressure on natural resources and associated social problems. Previous remedies have tried to make this situation less bad instead of better. Alternatively, a circular economic system may make sustainability more likely through a combination of - in order of prevalence - material reduce, reuse and recycle activities. Managing those activities in circular building projects requires new ways of organizing information, with or without digital technologies like BIM. The pathways toward closed-loop material flows are still unclear though as there are limited scientific insights on how construction managers can use information to reduce, reuse and/or recycle materials.

\section{Research strategy and perspective}

The background sections highlight an urgent need to fundamentally rethink the way building projects are managed. With this paper-based thesis, I intend to provide some guidance to that end. I consider the ideas behind the concept of a circular economy as a potential breakthrough in addressing many of the socioenvironmental problems persistent in the construction industry. Buildings, I argue here, must be seen as temporary depositories of valuable materials at specific sites. The metaphor of "buildings as material banks" (Debacker \& Manshoven, 2016) captures this view well, since it emphasizes that materials can be brought to, stored in and collected from man-made structures. In circular building projects, those materials are reduced, reused and/or recycled to the maximum extent possible. The main challenge of construction management is, accordingly, to close material loops or, in other words, to ensure that materials actually keep cycling. In this thesis, I therefore specifically focus on the connections between design and demolition life-cycle stages. But I break with the ingrained viewpoint that a building life-cycle starts with a design stage and is then followed by construction and operation only to end with demolition. Instead, given the large existing building stocks (particularly in developed

$8 \mid$ Introduction 
countries), I propose that a building life-cycle starts with demolition (of salvaged buildings) and is then followed with design, construction and operation stages in a continuous cycle. This thesis deals with the implications of that mind shift for demolition and design management.

The main research goal is, hence, to develop actionable knowledge on managing circular building projects through exploring how information can be used to reduce, reuse and/or recycle building materials. Each of the following chapters examines one particular use of information for one or more of those material strategies (Table 1). The first three chapters do this from a demolition management perspective, illuminating information usages in material recovery and reuse decisions (Chapter 1 ), subsequent coordination of demolition activities (Chapter 2) and the support of those activities with BIM-based methods (Chapter 3). The second three chapters do this from a design management perspective, shedding light on information usages in generating reversible design proposals with BIM-based methods (Chapter 4), evaluating those proposals with a virtual reality-based method (Chapter 5) and a reflective serious gaming approach (Chapter 6). The chapters are logically ordered along key, information intensive demolition and design activities within the proposed circular building life-cycle and, accordingly, focus on the management challenge of initiating and controlling material flows. Energy flows are not part of the scope (despite their importance), because the large majority of sustainability research for construction is already concerned with that theme. Energy may furthermore be viewed as infinitely available, given that our sun will burn for another 5.5 billion years. Material stocks, contrarily, are finite and they pose an actual and complex challenge for construction managers. The distinct chapters henceforth aim to

Table 1: Overview of chapters and research foci. Each chapter examines demolition or design managers' specific use of information to reduce, reuse and/or recycle building materials

\begin{tabular}{|c|c|c|c|c|c|}
\hline Phase & \# & Manager's use of information & 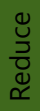 & 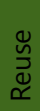 & 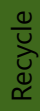 \\
\hline \multirow{3}{*}{ 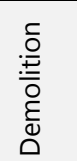 } & 1 & To decide about object recovery & & + & + \\
\hline & 2 & To coordinate demolition activities facing uncertainty & & + & + \\
\hline & 3 & To organize deconstruction practices with BIM-based methods & & + & + \\
\hline \multirow{3}{*}{ 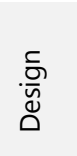 } & 4 & To organize reversible building design with BIM-based methods & + & + & \\
\hline & 5 & To communicate design intent and feedback & + & & \\
\hline & 6 & To reflect on design decisions & + & + & \\
\hline
\end{tabular}


produce actionable knowledge for the challenge: they are not oriented towards knowledge and understanding for their own sake, but towards the use of knowledge and understanding in tackling real-world problems and needs (Voordijk, 2009, p. 714).

Different research methodologies are adopted to provide a holistic understanding of demolition and design management in circular building projects (Figure 1). The methodological choices, as discussed in the separate chapters, are based on critical realism (see e.g. Archer, 1995; Bhaskar, 2009). This research philosophy firstly maintains that a material and social world exist, independently of people's perceptions, language or imagination (objective ontology). It secondly holds that observers can develop knowledge of the real world through interpretations which influence the ways in which it is perceived and experienced (subjective epistemology) (Edwards, O'Mahoney, \& Vincent, 2014). Critical realism recognizes that an objective world exists, but that the view of it is an interpretation and therefore subjective. As such, it is located midway a spectrum between the positivist position, where reality exists and can be assessed objectively, and the interpretive position, where reality is socially constructed and interpreted (Gray, 2013; Smyth \& Morris, 2007). The critical realism position offers a rationale for choosing multiple research methodologies (like ethnography and case studies): they can provide complementary views of management practices and the workings of the construction industry's organizations and projects. As such, this thesis responds to (and contrasts with) the construction management field's "apparent narrowness" in methodological

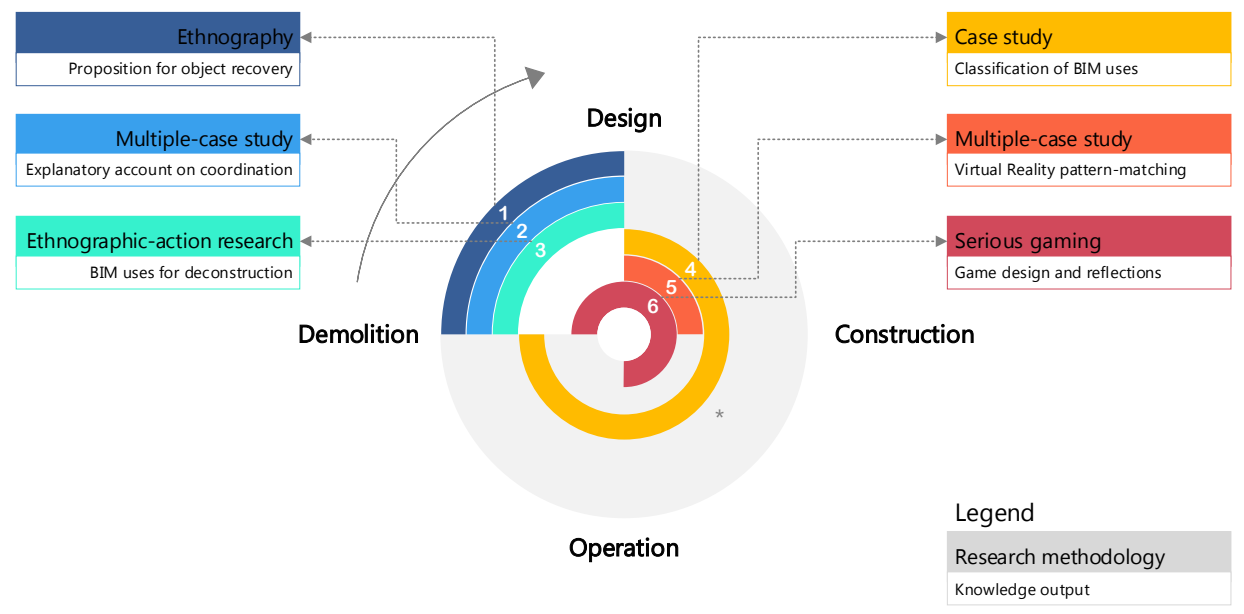

Figure 1: Research methodologies and knowledge outputs positioned within a (circular) building lifecycle.

* Arcs represent chapters connecting different life-cycle stages

10 | Introduction 
choices, "adherence to positivist methods" and "[disconnections] from the debates going on in many of the fields from which it draws" (Dainty, 2008, p. 10). The chapters' complementary views hence contribute to a richer understanding of demolition and design management practices for closing material loops.

\section{Thesis outline}

This thesis is structured around information uses for material reduce, reuse and/or recycle activities. The first three chapters focus on demolition management, the second three on design management. These chapters represent different papers and, as such, can also be read independently of each other (see Appendix I for a publication record).

Chapter one develops a general proposition for predicting whether (or not) a demolition contractor will recover any building objects. This study starts from the premise that any demolition contractor needs information to decide for each and every object in a salvaged building whether to recover that object for subsequent reuse or treat it as waste. Through collecting ethnographic data from a real-world 'best practice' demolition project, we systematically examined which objects were recovered for reuse - and which not. We then used an analytic induction method to formulate a set of necessary conditions that must be satisfied if a demolition contractor is to recover an object. If one or more conditions are not satisfied, we predict that the demolition contractor will decide not to recover the object.

Chapter two provides an explanatory account about how demolition activities are coordinated after such recovery decisions are made. This multiple-case study modifies the logic of information processing theory to reconcile it with idiosyncrasies present in enabling building material reuse or recycling. As such, we view demolition contractors in terms of their needs to gather, interpret and synthesize information. Using interview, observation and project data collected in three demolition projects, we uncover what uncertainties require demolition contractors to process information. We also explain that the demolition contractors responded differently to those uncertainties, depending on the focal end-of-life strategy at hand. The conceptualization, accordingly, allowed us to explain why some coordination efforts were effective and other ones not.

Chapter three reflects on the iterative improvement of three BIM uses that support those coordination efforts. This study is (among) the first to adopt an ethnographic-action research methodology for studying how demolition managers can use information to organize deconstruction practices (also called selective demolition) with BIM-based methods. It builds on the previous insight 
that information is an important organizational contingency during demolition and not only before. A literature review furthermore suggested that BIM-based methods had (almost) never been used during deconstruction practices. Hence, we built on these insights by iteratively developing and implementing three new BIM uses for deconstruction. These provide new opportunities to organize building material reuse and recycling practices.

Chapter four continues with BIM uses to organize generating reversible building design proposals. It starts from the insight that (future) reuse of building materials is greatly facilitated when a building is designed as a reversible structure. To that end, the chapter then examines how design managers can deploy BIM-based methods to use information more efficiently. A literature review is, accordingly, conducted to identify eight different BIM uses, like design authoring and quantity take-off (cost estimation). Based on two interview rounds with designers of a firm that is (uniquely) specialized in delivering reversible buildings, the study then elaborates on which of those eight BIM uses supported reversible design most. It ends with prioritizing the BIM uses in a classification scheme.

Chapter five explores how design proposals can be evaluated with a virtual reality-based method. Designers and clients (or their representatives) typically exchange information during review meetings to detect any errors and optimize a design proposal before construction. This can help to reduce material usage and waste. The chapter argues that there are some vast problems with the way reviews are usually organized though. From there, it suggests to improve this design management activity with a virtual reality-based method and explores the idea with two case studies. We acknowledge that the two real-world design projects central in the chapter did not aim for circularity per se, but argue that the findings nevertheless correspond well with earlier identified needs for different collaboration modes and business models in a circular construction industry.

Chapter six presents a serious game for reflecting on the impacts of (circular) design decisions. The benefits of design decisions can typically only be reaped after a long period of time and perhaps by a different firm in the supply chain. This limits the possibilities for design managers to gain experience and learn. As a potential solution, we systematically designed a serious game for construction supply chain management - though originally not for circularity. The game challenges any player to design, purchase and construct a tower with Lego bricks. This can offer a meaningful experience. The game visualizes and simulates information with which players can reflect on design decisions. Because of some of our game design choices, like scarcity and uncertainty regarding the timely

12 | Introduction 
delivery of bricks, we pose that the in-game suppliers may also (perhaps even better) be seen as demolition contractors. Our reflections, in hindsight, provide playful ways to learn about reducing and reusing building materials.

The thesis then ends with a discussion and conclusion. As an answer to the research gap identified above, the common threads between the six chapters are discussed in terms of information usages for closing material loops. This results in two key theoretical contributions to demolition and design management, which are discussed in detail. The contributions are also concretized to further guide practitioners in rethinking how building projects can be managed. As such, the scientific knowledge base developed in this thesis supports a transition from linear to circular building practices.

It is finally noted here that many other research activities were conducted over the course of this PhD research trajectory. Appendix II discusses four complementary research projects. I also: wrote proposals; followed courses; became a mentor and tutor of freshmen students; co-supervised bachelor/master students; contributed to formal reports and deliverables; held workshops and serious game sessions; and disseminated findings at scientific and practical conferences. These activities put the theoretical and empirical endeavors in perspective and, as such, contributed indirectly to this thesis. Appendix III presents a visual overview of the main research activities over time. 


\section{Chapter 1}

Recovering building objects for reuse (or not)

Marc van den Berg, Hans Voordijk \& Arjen Adriaanse 


\begin{abstract}
The construction industry faces growing socio-environmental pressures to close its material loops. Reuse of building objects can reduce both new production and waste. Previous research into circular economy, reuse potentials and object recovery issues has not yet explored why demolition contractors opt to recover some objects and destruct other ones. This research therefore attempts to uncover the conditions which lead to the recovery of a building object for reuse. Data collection consisted of approximately 250 hours of (ethnographic) participant observations during the course of a partial selective demolition project in the Netherlands, together with semi-structured interviews and project documentation. An analytic induction method was adopted to analyze the data collected. This resulted in a proposition strongly grounded in the data: a building object will be recovered for reuse only when the demolition contractor: (1) identifies an economic demand for the object; (2) distinguishes appropriate routines to disassemble it; and (3) can control the performance until integration in a new building. This proposition can guide future studies and practices aimed at increasing the reuse of natural resources.
\end{abstract}

Keywords: Building; Circular Economy; Demolition; Participant observation; Recovery; Reuse 


\section{Introduction}

Growing socio-environmental pressures to close its material loops stimulate the construction industry to consider reuse. Construction and demolition activities generate worldwide one of the heaviest and most voluminous waste streams, of which the majority ends up in landfills (Llatas, 2011). The industry is also responsible for more than half of the total global natural resources consumed annually and for more than a third of the total global energy use and associated greenhouse gas emissions (Iacovidou \& Purnell, 2016; Ness et al., 2015). These practices have severe impacts on the environment, including natural resources depletion, global warming, risks to public health, biodiversity loss and pollution of air, surface water and underground water (Cooper \& Gutowski, 2015; Mahpour, 2018). Acknowledging the importance and urgency of these problems, societal emphasis on circularity is growing, particularly in Europe and China (Jin, Li, Zhou, Wanatowski, \& Piroozfar, 2017; McDowall et al., 2017). Policy-makers accordingly strive to incentivize reuse because of the intuitive belief that it reduces both new production and waste (Silva, De Brito, \& Dhir, 2017). A scientific knowledge base then helps to develop effective strategies for closing material loops.

For reuse to occur, it is essential that demolition contractors shift their attention from destructing building parts to recovering them. The life-cycle expectation of a building generally does not exceed $50-60$ years, after which the property owner must make a decision about its future (Laefer $\&$ Manke, 2008). When adaptive reuse of the building through renovation or upgrading (Conejos, Langston, Chan, \& Chew, 2016; Remøy \& van der Voordt, 2014) is not feasible, the owner can select a demolition contractor to demolish the building. That firm adopts any of three demolition methods: conventional demolition, in which the building is converted into waste; complete selective demolition (also called deconstruction), in which construction steps are reversed so as to recover as many materials as possible; or partial selective demolition, which is a combination of the other two (Kourmpanis et al., 2008). These methods differ in the number of objects that is recovered, i.e. the amount of material that is diverted from landfills or incinerators to replace natural resources in material flows (Kibert, 2016). While previous studies have revealed some general barriers for reuse like regulatory barriers, economic constraints and a lack of public acceptance (Kibert et al., 2001), they are deficient in explaining when demolition contractors opt for recovery and when not. To further reuse practices, this lack of in-depth knowledge about demolition contractors' recovery decisions must be addressed.

This research hence seeks to uncover the conditions which lead to the recovery of a building object for reuse. It does not quantify the environmental or economic 
impacts of different deconstruction strategies, nor does it classify self-reported barriers or enablers for recovery; instead, our qualitative work conceptualizes recovery decisions (in terms of conditions) primarily based on participant observations during an actual demolition project. It starts from the premise that a demolition contractor needs to decide for each and every object in a building whether to recover that object or not. We define an object here as any physical part of a building that can be handled separately. Objects can be found in all "layers" (Brand, 1995) of a building: a lamp, ceiling tile, wiring, façade and column are all examples of objects. A building, in this view, constitutes (only) of objects that are all somehow connected to each other. In demolishing a building, a demolition contractor then faces two options for each object: recovery or destruction. Selecting the first option implies that the firm disassembles an object with the aim to offer it for future reuse; the second option implies that it treats the object as waste. When an object is destructed, the resulting waste may or may not be recycled: that is typically determined by a waste processing firm rather than demolition contractor (hence irrelevant here). Taking a qualitative approach, we develop a general proposition for predicting whether a demolition contractor recovers an object or not.

This paper is structured as follows. We start with a literature review on building object recovery and reuse in a circular economy. In the subsequent research design section, we present how we attempted to acquire detailed insights into actual demolition practices through unique participant observations and analytic induction. We then turn to presenting the results of that work: a proposition strongly grounded in the data about the demolition contractor's (binary) decision to recover or destruct any building object. After discussing the limitations and implications of the study, the paper finally ends with suggestions for strategies that target object recovery.

\section{Literature review - object recovery and reuse in a circular economy}

A literature review on reuse predictability here suggests three knowledge gaps, sorted from the abstract to the concrete. First, circular economy research tends to overlook the potentials to close material loops through reusing building objects. Second, building research concerned with reuse insufficiently considers recovery issues. Third, research dealing with object recovery has neglected the demolition contractor's point of view. 


\section{Circular economy research for buildings}

The concept of a circular economy is recently gaining momentum as a way to overcome current production and consumption patterns that put a significant burden on our planet and its environmental capacity. The economic model that still dominates society is based on a simple, linear process: take, make, use and dispose, with little or no consideration for the waste generated at each step. However, the world has finite boundaries and the wastes generated during production and consumption "come around to haunt us as pollution as they eventually end up either in a landfill or are dispersed in ways that contaminate our environment" (Sauvé, Bernard, \& Sloan, 2016, p. 53). Negative environmental effects threaten the stability of economies and the integrity of natural ecosystems essential for humanity's survival (Ghisellini et al., 2016). As an alternative, the circular economy model proposes a restorative or regenerative industrial production system through: circulating materials as long as possible with minimal loss of quality, shifting towards the use of renewable energy and eliminating toxic chemicals (Ellen MacArthur Foundation, 2013). This is most frequently depicted as a combination of reduce, reuse and recycle activities (Kirchherr et al., 2017). The concept is rooted in several schools of thought such as cradle-to-cradle approaches, where waste is considered a value-producing resource (McDonough \& Braungart, 2010; McDonough, Braungart, Anastas, \& Zimmerman, 2003), biomimicry, which looks to nature for sustainable solutions to design challenges (Benyus, 1997) and industrial symbiosis, where waste from one industry replaces raw material in another (Graedel \& Allenby, 2010). The main contribution of the circular economy is that it decouples resource depletion and economic growth, making "sustainability more likely" (Sauvé et al., 2016).

Framed from a circularity perspective, building research has focused more on energy rather than material flows. Even though the construction industry is the most resource intensive industry in the world (Iacovidou \& Purnell, 2016), much of the recent circularity thinking has been on short- and medium-lived consumer products instead (Adams et al., 2017). Construction research that aims to contribute to a more sustainable built environment is still mostly concerned with energy consumption and carbon emission issues (Hossain \& Ng, 2018; Pomponi \& Moncaster, 2016). Recent studies include, for example, an analysis of the embodied energy use of China's construction industry through a multi-regional input-output model (Hong, Shen, Guo, Xue, \& Zheng, 2016) or a case study approach to evaluate and assess the energy efficiency of buildings (De Lieto Vollaro et al., 2015). Although important, research that focuses only on energy tends to overlook other environmental impacts associated with winning and processing of raw materials, such as scarcity or the impact on biodiversity of mining or drilling operations (Cheshire, 2016, p. 87). To secure that actual 
environmental impacts of circular economy work towards sustainability, many of their advocates accordingly argue that more research is needed into closing material loops on a building level (Leising et al., 2018; Pomponi \& Moncaster, 2017).

\section{Buildings and reuse potentials}

The main strategy to close material loops for buildings at the end of their useful life is reuse. The waste hierarchy (also called Lansink's Ladder) indicates an order of preference for the latter part of an object's life-cycle: prevention, minimization, reuse, recycling, energy recovery and disposal (Parto et al., 2007). The circular economy model similarly prioritizes strategies that require less changes to an object because of potential savings on the shares of material, labor, and embedded capital and on the associated externalities (Ellen MacArthur Foundation, 2013). For buildings, this implies that refitting and refurbishment are prioritized over demolition and rebuild, but other strategies at a building object level need to be considered when that is impossible. A preferable option is then reuse, in which an object is used again either for its original purpose or for a familiar purpose, without significantly altering the physical form of it. Recycling is reprocessing recovered objects with a manufacturing process and making it into a (component for a) final object again (Kibert, 2016). Even though much policy is oriented towards recycling (Allwood et al., 2011), the strategy is less preferable because it typically reduces the object's quality, potential for future uses and economic value - also called downcycling (Chini, 2007). Concrete objects, for example, become secondary aggregates and solid timber may be reduced to particle boards. Disposal (through landfilling) and energy recovery (through incineration) are common strategies, but least preferred as they waste material resources out of the loop forever. From a material efficiency perspective, object reuse is hence the most preferred strategy for buildings that are nominated to be demolished.

That insight has fostered research into reuse potentials. Design researchers have been studying how a building's design can be optimized to allow for adaptations on one hand and the recovery of objects for reuse on the other hand (Crowther, 1999, 2018; Durmisevic, 2006). The design philosophy they put forward, called design for disassembly, aims to design-out waste through careful consideration at the early design stage. Buildings are reinterpreted as collections of valuable material resources that must be preserved over different life-cycles. Great inspiration for this work is the conceptualization of a building as six layers with different longevities by Brand (1994): stuff, space plan, services, skin, structure and site. Because of the (expected) different rates of change of the objects 20 | Recovering building objects for reuse (or not) 
belonging to these layers, the main guiding principle of design for disassembly is that objects must be easily recoverable. Guidelines derived from that principle include (i) the use of reversible building connections; (ii) allowing their accessibility; and (iii) minimizing the number of connections (Akinade, Oyedele, Ajayi, et al., 2017; Crowther, 1999; Durmisevic, 2006; Guy, Shell, \& Esherick, 2006). Reuse potential is then a - theoretical - measure of an object's ability to retain its functionality after the end of its primary life (Iacovidou \& Purnell, 2016). Akinade et al. (2015), for example, used a building design's bill of quantity to capture the design's disassemble-ability in a mathematical score. Remarkably, research into reuse potentials focuses on new buildings with new objects and, consequently, has limited impact for the existing building stock. To bring about circularity in buildings, it is thus necessary to look at the challenges associated with recovering objects from salvaged buildings (Koutamanis et al., 2018).

\section{Reuse enabling recovery practices}

Research into recovery issues has started with identifying and prioritizing abstract drivers and barriers for the construction industry as a whole. Mahpour (2018), for example, used quantitative surveys to rank potential barriers in moving towards more circular construction and demolition waste management practices. One of the conclusions here is that "sorting, transporting, and recovering processes" is among the most important barriers, a generic insight that does not explain how or why certain objects may or may not be recovered. Other studies have similarly identified critical success factors for recovery (Akinade, Oyedele, Ajayi, et al., 2017), factors impacting demolition waste generation (X. Chen \& Lu, 2017), benefits and constraints of deconstruction (Iacovidou \& Purnell, 2016), and drivers and/or barriers for reverse logistics in construction - sometimes substantiated with (some) empirical data (Chileshe, Rameezdeen, \& Hosseini, 2016; Chileshe et al., 2018) and sometimes limited to existing literature (Hosseini et al., 2014; Hosseini et al., 2015). Aiming for more in-depth insights, Gorgolewski (2008) alternatively used case studies to reveal "some challenges" for designers working with recovered building objects, like complexities due to the timing and availability of materials and the lack of a coordinated supply chain. An important shared insight from these studies is that object recovery is not only challenging because of project-specific uncertainties but also because of the socio-technical organization of the (selective) demolition process.

Research has nevertheless neglected reuse enabling recovery practices from the demolition contractor's point of view. Even though a building owner or municipality may mandate the recovery of some objects in a demolition project 
(Chini \& Goyal, 2011), the demolition contractor - here viewed as an autonomous decision-maker - must still opt to actually engage in either recovery or destruction practices for every (other) building object. To assist in such recovery decisions, previous studies have compared different demolition methods. This includes evaluations of the economic (Coelho \& De Brito, 2011) and environmental (Coelho \& De Brito, 2012; Diyamandoglu \& Fortuna, 2015; T. Wang et al., 2018) implications of different demolition strategies. Other studies could build on that by developing decision-making models, for example to compare costs, energy use and carbon emissions with data from a building information model (Akbarnezhad, Ong, \& Chandra, 2014). In practice, however, reliable building information is often absent at the end-of-life phase (Volk et al., 2014). Practitioners also appear to rely heavily on experience and implicit knowledge (Phelps \& Horman, 2009) when taking recovery decisions. Few writers have been able to draw on those pragmatic realities. Previous research has not clearly explained why demolition contractors opt to recover some objects and destruct other ones. More in-depth research is thus needed to understand the recovery decisions from the demolition contractor's point of view.

\section{Research design}

This research seeks to uncover the conditions which lead to the recovery of a building object for reuse. We had the rare opportunity to not only closely observe but also participate in a "best practice" demolition project where many objects were recovered for subsequent reuse. Through systematically recording the (ethnographic) participant observations and complementary interviews and documents, we gained detailed insights of actual recovery and destruction practices. Using analytic induction, we then iteratively developed a proposition that accounts for demolition contractors' recovery decisions.

\section{Ethnographic observations, interviews and documents}

Because we aimed to develop a proposition that is strongly grounded in the data, we chose to get our hands dirty and conduct, first and foremost, (ethnographic) participant observations. Ethnography is traditionally adopted by anthropologists to describe a human culture from a native's point of view (Spradley, 1979, 1980). The method involves fieldwork in which a researcher takes part in the daily activities, rituals, interactions, and events of a group of people as a means to capture the explicit and tacit aspects of their routines (Musante $\&$ DeWalt, 2010). The extended researcher-engagement provides a powerful way to illuminate working practices in new ways (Löwstedt, 2015; Phelps \& Horman, 22 | Recovering building objects for reuse (or not) 
2009). Since ethnographic methods are well suited to provide in-depth insights about the material and social contexts of a construction site, Pink, Tutt, Dainty, and Gibb (2010, p. 658) argue that researchers can benefit from "the luxury of time (with the workers), the ethnographer's eye, and the ear of management and the industry."

The ethnographic observations here focused on the workplace realities and socio-material experiences in a demolition project. The first mentioned author was granted access to the site after passing an official health and safety exam and verifying insurance coverage for personal accidents. He then visited the site on a nearly daily basis for the entire project duration, making participant observations for a total of about 250 hours. During these site visits, he sought to understand demolition practices not only through observing them but also by attempting to learn and master them himself to the fullest possible extent. As such, the researcher tried to become an "active participant" (Spradley, 1980, p. 60 ) in a wide range of tasks, including: installing construction fencing, removing ceiling tiles, cutting electric wires, moving things around, sorting waste materials, and rigging/hoisting loads. He thereby systematically documented his observations and experiences in a field diary. These field notes initially covered a wide range of issues, but became more specific and focused during the course of the project (together with sharpening of the research question). Moreover, the researcher took over 800 pictures and videos of particular working practices (aimed at either object recovery or destruction), which corresponds with "recent innovative approaches to doing ethnography" (Pink et al., 2010, p. 649). He also audio-recorded a few key discussions about recovery issues with the consent of the workers involved in them.

Next to these rich ethnographic observations, this study was informed by complementary interviews and project documentation. To better understand the (more abstract) relationship between demolition and subsequent reuse activities in projects like the focal one, the first author conducted five interviews with decision-makers that were recognized as 'experts' in distinct parts of the focal recovery-reuse process (i.e. one site supervisor, one designer, two project leaders and one warehouse manager). The researcher had identified one key informant before, while the other persons were referred to by that person (snowballing). Using a semi-structured format (Leedy \& Ormrod, 2010), the interviews had a fixed set of questions (about how and why objects were reused) and offered the possibility to inquire further when that was considered necessary. All of the interviews were audio-recorded. One key informant also sent relevant project documents, like the original construction drawings $(1.65 \mathrm{~GB})$ and a framework contract. 


\section{Analytic induction}

A qualitative method called analytic induction was adopted to analyze the data collected. This method is particularly useful to build up causal explanations of phenomena "with none of the wishy-washy tendencies and associations that are the product of statistical analysis" (Bernard \& Ryan, 2010, p. 328). The idea is to iteratively develop a proposition that explains a certain phenomenon through first formulating a preliminary hypothesis that accounts for just one unit of analysis and then refining that hypothesis through adding and testing more units of analysis. The process is stopped when the evolving theory explains every new unit of analysis one adds; the end result is thus a proposition.

The analytic induction process here started with preparing the data. The first author digitized the field diary, transcribed the audio recordings verbatim, sent summaries of the interviews to the informants for verification purposes and organized the pictures, videos and project documents in a database. Using qualitative data analysis software (ATLAS.ti), the researcher then read, marked and named small chunks of the field diary and the interview transcripts one by one. This is called initial or open coding. A total of 83 different codes were applied to the data during the first round of coding. This helped to identify potentially useful concepts to explain why some building objects were recovered for reuse and others not. The researcher then examined one unit of analysis that is, the recovery or destruction of one building object - and expressed the demolition contractor's decision in conceptual terms. He continued with examining other building objects, using the pictures, videos and project documents to verify recovery decisions. The researcher constantly tried to discover similarities and differences with the earlier objects. During this process, intermediate versions of a theory that correctly explained some (but not all) recovery decisions were discussed among all three authors - an essential step to ensure rigor: multiple researchers can foster a higher a higher level of conceptual thinking than individuals working alone and can reduce bias because of incorporating control of each other's interpretations (Boeije, 2009). The first author also presented an early version of the theory to three demolition experts during a workshop (a site supervisor, project leader and director) to be able to incorporate their feedback. Such discussions and feedback subsequently led to modifications to the coding scheme, the concepts used and the evolving theory. In the end, we declared our hypothesis stable when it correctly 'predicted' the outcome of a recovery decision for each object that we examined (and in all building layers). 


\section{Project: demolition of a nursing home}

The focal project concerns the partial selective demolition of a temporary nursing home located in the Netherlands, a country with one of the highest recycling rates in Europe (Gálvez-Martos et al., 2018). The nursing home had been constructed by a system builder that specialized in modular and prefabricated buildings. The façade, for example, consisted of distinct objects with (among others) windows, insulation and plasterwork that were originally produced offsite. We selected this project for our research since we knew that many (but not all) of these large objects were recovered for reuse. The project, hence, provided rare opportunities to closely investigate the phenomenon we were interested in. The building that had to be demolished was characterized by a gross floor area of approximately 2,400 $\mathrm{m}^{2}$ and consisted of 40 bedrooms and 11 bathrooms, 5 living rooms, 1 elevator and some other rooms (like offices or storage). Since the building was - as planned - no longer needed after just over five years in use, the system builder was asked to demolish it. The system builder, in turn, subcontracted a demolition contractor with which it has a long-term partnership for the actual demolition works. That firm faced a nearly empty building that was disconnected from water, gas and electricity at the start of the project. Even though the system builder expected the demolition contractor to act in line with their contract, it was the latter firm which had to make the decision to actually recover or destruct the building objects (over and over again).

\section{Results - conditions for object recovery}

Before any building object can get a new life, it first needs to be recovered for reuse. Here, we attempt to arrive at a general statement of the necessary conditions which have always been present when a demolition contractor recovers a building object for reuse. Only when all conditions outlined below are met will a building object be recovered for reuse rather than be destructed (Table 2).

\section{I-Identify economic demand}

A demolition contractor does not typically attempt to recover a building object for reuse. The firm's focus is, by default, on establishing a quick and cost-efficient waste stream during the destruction of a building. It is thereby financially attractive to separate materials per type, since landfilling and recycling firms apply different market prices. The firm transports the waste to the waste processing firm with the best financial quotation, normally the cheapest one. The 
Table 2: Exemplary building objects that were either recovered for reuse or not

\begin{tabular}{|c|c|c|}
\hline Layer & Recovered for reuse & Not recovered for reuse (destructed) \\
\hline Stuff & $\begin{array}{l}\text { Microwaves; Kitchen cabinets; Hot } \\
\text { plates; Flowerpots; Curtains; Sun } \\
\text { screen }\end{array}$ & Mirrors \\
\hline Space plan & Stairs; Door fittings & $\begin{array}{l}\text { Interior walls; Doors; Ceiling tiles; } \\
\text { Linoleum; Cable ducts }\end{array}$ \\
\hline Services & $\begin{array}{l}\text { Air conditioning units; Sockets; Door } \\
\text { closers; Faucets; Refrigerators; Fire } \\
\text { hose reels }\end{array}$ & $\begin{array}{l}\text { Radiators; Toilets; Lighting; Electrical } \\
\text { wiring; Elevator; Countertops }\end{array}$ \\
\hline Skin & $\begin{array}{l}\text { Façades; Timber coverings; } \\
\text { Foundation plinths }\end{array}$ & $\begin{array}{l}\text { (Special) façades; Sliding doors } \\
\text { entrance }\end{array}$ \\
\hline Structure & $\begin{array}{l}\text { Floors; Columns; Roofs; Wind bracing; } \\
\text { Lift pit; }\end{array}$ & (Special) floors; Foundations \\
\hline Site $^{1}$ & Brick pavement; Hedges; Fencing & - \\
\hline
\end{tabular}

demolition contractor only starts to shift its attention from destructing to recovering when it realizes that there is an economic demand for an object, that is, when enabling reuse may be more profitable than the alternative.

The demand for most of the focal building's structural and façade objects was clear right from the start of the project. The builder of the nursing home had already secured the right to demolish the building during the construction phase. That would enable this system builder to take back its 'own' modularized and industrialized building objects and to reuse those in other projects. Here, the system builder planned to directly reuse many of the nursing home's structural and façade objects for the construction of a high school, a project it had recently been selected for. Exemplary objects planned for reuse include floor, column, roof and façade objects. "Those are the components that we are interested in [to reuse]," said one of the system builder's project leaders. "Because these are modularized products, the designer knows what the building constitutes of. So he will design a new building with resources from the old building." Structural objects or façades that cannot be reused directly, can be temporarily stored in a facility of the system builder first. The intended direct or indirect reuse of such objects creates a demand to recover those objects from the nursing home.

The demolition contractor identified those demands from several documents and working practices. The firm, to whom the system builder outsourced the deconstruction works, is a fixed partner of the system builder. "If we plan to 26 | Recovering building objects for reuse (or not) 
disassemble [one of our buildings], we will do that together with [that demolition contractor]," explained a project leader. "He understands our buildings and how we think." The demolition contractor's site supervisor confirmed: "[the system builder] is interested in getting the building shell back." That interest was evidenced by disassembly drawings that he had received from the system builder. Those drawings represent floor plans and cross-sections of the building with numbers and colors indicating which floor, roof or façade objects the system builder plans to reuse and where. Almost all floors, for example, were necessary for the construction of the aforementioned school. One ground level floor and two first storey floors, however, were classified as waste. A closer examination revealed that those three floors, located near the elevator shaft, had different shapes (e.g. L-shapes) and sizes than the other floors. Since that would make it more difficult to reuse them, the system builder had not requested them back. That firm wanted to store five other floors with different (yet not uncommon) sizes though, as it expected to be able to use those in some other project in the future. The system builder thus used drawings and other (contract) documents to request the recovery of certain structural and façade objects for reuse.

While the demand is less obvious for most other building objects, the demolition contractor appeared to have a fine understanding about what recovery practices are profitable and what not. The site supervisor and the foreman of the project frequently used the phrase that "you can [or cannot] make money with that" when referring to groups of building objects. The toilets in the nursing home were not recovered for reuse, for example, because the firm believed nobody would be interested in a used toilet. The lighting systems were also considered outdated. Contrastingly, the demolition contractor believed that it could make money with reselling (among others) door closers, faucets and refrigerators because there is a demand for such second-hand objects. One early morning, that became also painfully clear when the ethnographic researcher and two other demolition workers discovered that thieves had managed to enter the building and taken away some disassembled bathroom appliances. The (legal) interest in reusable objects was also evidenced by three other events that the researcher witnessed. A woman living opposite of the nursing home expressed her "cheeky" interest in two large flowerpots outside the nursing home, two other passersby asked whether they could have a look at the kitchen appliances (eventually buying a kitchen cabinet, hot plate, microwave and refrigerator) and another man living in the neighborhood wanted to buy 14 large timber beams that formed an architectural feature of the façade. The site supervisor explained that such events were financially interesting because some money could be earned and landfill disposal costs were saved. 
For all building objects that were recovered for reuse, the demolition contractor expected that it could make some money with them. A building object was destructed when no potential buyer was identified through, for example, professional documents/contracts, direct on-site meetings or indirect sales channels. One necessary condition to recover an object for reuse is thus that the demolition contractor identifies an economic demand for that object.

\section{II - Distinguish disassembly routines}

Even after a demolition contractor realizes that a demand for a particular building object justifies its disassembly, recovery of the object may not take place. The potential reapplication of an object requires more skillful and disciplined disassembly routines than the reduction of that same object to (recyclable) demolition waste. As our ethnographic observations and interviews suggest, the decision to recover an object is also influenced by the demolition contractor's ability and willingness to adopt those routines.

Disassembly routines depend on the type, accessibility and number of connections a building object has with other objects. Even though the nursing home was designed as a reversible structure, some of its objects had irreversible or inaccessible connections. Recovery of the linoleum floor covering, for example, was impossible because a strong glue had been used to attach it to the concrete floors. The metal-stud interior walls could not be disassembled as distinct objects since its gypsum plates and glass wool insulation made its connections to floors and ceilings inaccessible. Cables and pipes had too many connections with walls, ceilings and other objects and their tangled arrangement made it difficult to get an overview of each of them. For many other objects, however, the series of activities needed to disassemble them with minimal damage was more straightforward. The nursing home's flowerpots, curtains and ceiling tiles, for example, had a connection with other building objects based on gravitational forces. They could be accessed easily and the number of disassembly steps is limited: one demolition worker could simply lift these objects. A refrigerator or microwave likewise only needed to be unplugged. Kitchen and bathroom appliances, like cabinets, faucets, and sinks, had fastener-based connections (e.g. bolt-nuts or screws) that could be loosened with standard tools.

But also for larger building objects, the demolition contractor had established specific disassembly routines. As such, the ethnographic researcher participated in the recovery of the modular façade (as distinct objects). That started with one (other) demolition worker removing three screws at the bottom of an object to partly detach a façade object from the concrete floor it was attached to. A

28 | Recovering building objects for reuse (or not) 
demolition worker on the roof attached two chains, hanging from a crane hook, to two rope lifting loops on the top left and top right side of the façade object. He then completely detached the façade by removing the three remaining screws on the top of the façade object. The crane operator subsequently put the (then vertically hanging) façade object on the ground and let it slowly fall over to one side. "The façade must be rotated a quarter turn because it would otherwise be too high for transport," explained one of the demolition workers. He detached one of the two chains and attached it to a third rope lifting loop at the bottom of the object. The crane operator lifted the (then horizontally hanging) object again and finally put it into a lifting yoke with the help of one more demolition worker and the researcher.

Disassembly routines like these also extend to more thoughtful handling of adjacent objects and the skillful adoption of specific tools. To illustrate that, the aforementioned linoleum floor covering was removed with a special machine in order to recover the concrete floors. But removing pieces of linoleum near the edge of a floor could, in turn, lead to damage to the façade. Bumping into the façade with that machine could not be completely prevented. The foreman explained that they thus tried to reduce the risk of damage by unscrewing the bottom part of a façade object first: "if [the machine operator] then hits the façade, he will push it a bit outward instead of that he makes a hole in the wall." Here, the recovery of one object depends on the demolition contractor's skills to carefully demolish other objects. The site supervisor revealed this: "[a few men of the system builder] taught us, like, this is how you need to pay attention to the façades." He then added that they gradually tried to get their own speed in those routines, particularly through developing specific supportive tools. For example, demolition workers found a solution for a recurring practical problem in hoisting floors, which was later praised by the system builder as "real craftsmanship." It had been difficult to precisely locate the position of the four hoisting rings in a concrete floor since those rings were poured over with mortar after assembly. Demolition workers discovered that a strong magnet is attracted to those rings (even more than to rebar) and could thus be used to locate the positions of the rings. Other inventions include a sharp tool to cut through the roof covering material from below so as to separate two roof objects and a custom-made extension for a drilling machine that made it easier to loosen bolts above the head. All of these offer technical possibilities to efficiently disassemble building objects.

That must be complemented with the commitment to actually recover those objects. Many demolition workers found it "interesting" to know that an object would be reused. Throughout the project, the site supervisor and/or the foreman instructed the ethnographic researcher and other demolition workers why careful 
handling was expected for some objects and not for others. One worker who was, in the opinion of the site supervisor, not committed enough to carefully disassemble certain objects, was replaced and sent to another demolition project where "he can just destruct things." The site supervisor repetitively told the ethnographic researcher and other workers that he "enjoyed it a lot to try making money" with reusable building objects, like the kitchen appliances. Demolition workers also seemed to be committed to enable reuse with minimal damage for most large objects. As such, "this is what I really like doing," said one of the workers when he removed the last screws with which a façade object was still attached to a floor and then gave a 'hoisting' signal to a crane operator. Interviews furthermore suggested that the demolition workers prefer cleaner disassembly tasks. Destructing the metal-stud interior walls with machinery, for example, generated a lot of dust and dirt. "When it is a system wall type, ... I prefer disassembling it manually rather than with a crane," argued the site supervisor. "Why? Because in terms of speed, when you do it manually, it is almost as fast yet much cleaner." The possibilities to assign committed workers to disassembly routines, accordingly, affect recovery decisions.

The demolition contractor distinguished appropriate disassembly routines for all building objects that were recovered for reuse. When the object's connections were irreversible, inaccessible or innumerable so that skillful and disciplined disassembly routines were practically not available, the building object was destructed. A second condition to recover an object for reuse is thus that the demolition contractor distinguishes appropriate routines to disassemble that object.

\section{III - Control future performance}

One more condition needs to be satisfied for a building object to be recovered for reuse. From the demolition contractor's perspective, it only makes sense to disassemble an object from a salvaged building when that object can (eventually) also be integrated in a new building again. The integration is limited though when it cannot be recovered properly (in due time) or when storage and/or reparation is impractical. As outlined here, this implies that the practical possibilities of a demolition contractor to control the performance of an object until future reintegration also influence that firm's decision to recover an object for subsequent reuse or not.

Sufficient time is needed to disassemble an object without diminishing its performance. For some objects, applying a disassembly routine takes about the same time as destructing it. "I think the doors are a nice example," said one 
(system builder's) project leader to the site supervisor. "Actually, you just take them out [of their frames] ... even though you cannot make any money with them." The doors are disassembled (and then thrown away) simply because that is cleaner and can be done in the same time. For almost all other objects, recovery through careful disassembly and handling takes more time to be able to control their future performance. Two demolition workers who cleaned the bottom side of the roof, for example, told the ethnographic researcher that their job was very time consuming because they had "to remove all kinds of small things, like hooks and nails." Referring to another project context, one of the workers said that "a building like this will be demolished within a few weeks. But nothing is [recovered] then." That corresponds with regular lunch break stories about supermarket renovations that other demolition workers shared with the ethnographic researcher. They argued that there is a lot of time pressure in those projects, with employees working day and night shifts, as management typically wants to reopen the supermarket as fast as possible. A remarkable difference, according to them, is that in those demolition works "nothing" is recovered for reuse (yet materials are separated for recycling). Those time pressures were less high in the focal project and, consequently, did not limit demolition workers in following specific disassembly routines.

A reusable object also needs to be stored for a shorter or longer period of time. When an object can be integrated in a new building directly, storage time is minimal. The ethnographic researcher, for example, moved some large flowerpots to another building where they were directly functional again. The system builders' project leaders argued that some storage time is, however, usually necessary even when direct reuse is possible, such as when a building owner wants to relocate an entire building: the first objects needed at the new location are then the foundation piles and beams, but those are disassembled last. Here, almost all of the nursing home's floor, roof, column, wind bracing and staircase objects were planned to be reused directly. Similar to the façade, these objects were shortly stored on site for the time between disassembly and transportation. Most façade objects were, however, transported to a storage and reparation facility of the system builder first for a quick paint job (before transporting them to the same new site). For all of these objects, the demolition contractor could control their (short) storage with ease: the objects are weatherresistant and there was enough space on the site.

With indirect reuse, storage becomes a greater source of concern for the demolition contractor. The nursing home's air conditioners, sinks, fire hose reels and other smaller objects were all piled up on pallets after they had been disassembled. Planks separated the objects from each other, while plastic foil somehow protected the objects against dust and dirt. The façade and the interior 
walls also helped to protect these objects against wind and rain. Near the end of the project, before disassembling of the structural objects commenced, these objects were transported to a storage hall of the demolition contractor for later resales. The ceiling panels represented, however, a group of objects for which the demolition contractor could not ensure that they maintain their physical and/or structural properties over an indefinite storage time. The site supervisor and one of the system builder's project leaders argued that they quickly deteriorate when they get wet, which is (more) likely with indirect reuse. If they were to be reused, they would need to be stored in a dry and warm place. The site supervisor and project leader both considered that "too expensive" and one added that a buyer will likely reject a whole package of ceiling panels "if only one little hook or something... remains behind." Another project leader illustrated this problem for the radiators: "when you disassemble a radiator from a wall, you must store it..., so you clean it, it is transported, it is sealed, at the next project it is unpacked again, it must be cleaned again, you have to let water run through it otherwise it even freezes. ... It is green to reuse... but actually no money is earned with it." Another project leader hypothesized: "doors, for example, if you put those in a hall for half a year, [then] you can forget it! ... But if you only have them for a short while... then you can do a lot more with them [in terms of reuse]." The demolition contractor's possibilities to temporarily store an object for future reuse hence affect the recovery decision.

In line with that, reparation of disassembled (and stored) building objects may be necessary to guarantee their functional quality. For the façades and the structural objects, the system builder operates a storage and reparation facility. The demolition contractor reported and sent a roof object to this facility for a detailed technical inspection after that object had fallen from the crane during an incident on site. More regular reparations with which the value of recovered objects can be guaranteed are painting (e.g. to fix discolored parts) and coating (e.g. to comply with fire regulations) jobs. For other objects, the demolition contractor reacted itself to (unexpected) damages. A crane had, for example, leaked a considerable amount of oil on the brick pavement. Apart from cleaning up the oil, the demolition contractor responded by cleaning those bricks to ensure their reusability. Conversely, the demolition contractor could not control that many service objects would maintain their functionality. The sliding doors of the main entrance, for example, had a sensor and electronic mechanism that the firm considered very fragile. The site supervisor explained that those electronic components would oxidize after disassembly and that "you will [then] get hitches and malfunctions if you reuse those doors." These doors, as well as many other service objects, subsequently ended up in a waste container. 
For all building objects that were recovered for reuse, the demolition contractor could control the performance until they would be integrated in a new building again. The demolition contractor had sufficient time for careful disassembly and could ensure that the objects maintain their physical and structural properties for shorter (on-site) or longer (off-site) storage times and/or could respond to damages with necessary reparations. Building objects were destructed when the demolition contractor could not ensure their performance until future reuse. A third necessary condition to recover an object for reuse is thus that the demolition contractor can control its performance until it is integrated in a new building.

\section{Conclusion and discussion}

This research uncovered three conditions which together lead to the recovery of a building object for reuse. We embraced the rare opportunity to conduct (ethnographic) participant observations during a demolition project. This allowed us to examine the responsible demolition contractor's recovery decisions for many building objects in all layers of the focal nursing home. The observations, together with complementary interviews and project documentation, were systematically recorded and analyzed with a method called analytic induction. From this, we derived a proposition strongly grounded in the data: a building object will be recovered for reuse only when the demolition contractor: (1) identifies an economic demand for the object; (2) distinguishes appropriate routines to disassemble it; and (3) can control the performance until integration in a new building.

\section{Recovery - if all conditions are satisfied}

For all building objects that the demolition contractor recovered, all three conditions were satisfied. The nursing home's flowerpots, staircases and columns have in common that the demolition contractor considered recovering them profitable (condition one), distinguished routines to disassemble them (condition two) and could control their performance until integration in a new building (condition three). For these (and many other) objects, the demolition contractor opted for recovery: they were disassembled with the aim to offer them for future reuse. Next to these striking similarities, a closer examination of the results also suggests differences in the way in which the three conditions can be fulfilled, depending on the type of objects. 
The first condition is that the demolition contractor identifies an economic demand for the object. That is, there must be a demand for the object, recovering is considered profitable and the demand is identified in the first place. For many large building objects like floors, roofs and façades, the demolition contractor is aware of the intended reuse not only because of formal contract documents and drawings but also because it understands the business processes of the system builder (as fixed partner for demolition works). The planned reuse of other objects was not governed with contract documents. Some objects, like door closers and air conditioners, could be sold through indirect sales channels like traders or online marketplaces, since the demolition contractor identified a mature market for such second-hand objects. Other ones, like timber beams and some kitchen appliances, were recovered only after the demolition contractor recognized that a passersby was interested in buying them. Had such a person not seen the demolition works and enquired for something that he/she needed, then the demolition contractor would not be aware that that person would be willing to pay for a particular object. Hence, the demolition contractor can identify an economic demand through formal contracts and documents, indirect sales channels or meetings on site.

The second condition is that the demolition contractor distinguishes appropriate routines to disassemble an object. This implies that the object can technically be disconnected from other objects and that the demolition contractor is also skilled and disciplined to do so. As we discussed, the nursing home was designed and built as a reversible structure through the use of mostly modular and prefabricated objects with reversible, accessible and limited connections with other objects. Recovering those objects was only possible by strictly following a specific order of disassembly steps and with the use of heavy equipment, in particular a crane. Other objects, like sun screens and faucets, were easier to handle due to their (smaller) size and (lower) weight and thus only required simple tools and steps for disassembly. Depending on the type of object, the demolition contractor hence needs to distinguish different steps, skills and tools/equipment for appropriate disassembly.

The third condition is that the demolition contractor can control the object's performance until integration in a new building. This means that there needs to be sufficient time available for proper disassembly and that the demolition contractor can ensure that the object maintains its physical and structural properties during storing and subsequent handling. Objects differ in the number and type of measures with which the demolition contractor can ensure the value until future reuse. The floors, roofs, columns and other system objects maintain their properties when shortly stored outside, at the site. Other objects, like air conditioners and microwaves, needed to be wrapped into foil and could only be 34 | Recovering building objects for reuse (or not) 
stored inside, in a closed off space, to protect them against weather influences, other demolition activities and petty criminals. Likewise, we discussed differences in the possibilities to conduct reparations so as to restore and ensure the performance of objects with, for example, a fully functional storage and reparation center in place for the system objects. The demolition contractor can thus control an object's performance in a new building with different combinations of protective and reactive measures aimed at value protection.

\section{Destruction - if any conditions are false}

For all building objects that were destructed, one or more of the hypothesized conditions were not satisfied. The firm did not engage in recovering mirrors that were left behind in the nursing home, because it did not identify any potential buyers (condition one). Linoleum floor covering was not recovered since the firm was unable to disassemble that appropriately (condition two), particularly because of the used glue. The main entrance's sliding doors were not recovered, because the firm could not ensure that they would still work as supposed at some unknown time in the future (condition three). The mirrors, linoleum floor covering and sliding doors, together with many other objects, all ended up in one of the waste containers. Though a waste processor may (or may not) recycle materials of the destructed objects, their functional lives all ended at the examined site. Irrespective of the building layer, if for an object any of the three conditions were false, the result was destruction.

\section{Implications and limitations of proposition}

The insights into the conditions for object recovery we attempted to provide here have a number of implications for research and practice. Based on a fieldworkbased approach, this study complements circular economy, reuse potentials and object recovery streams of research through focusing on, respectively: closing material loops (rather than energy flows), reusable objects from existing buildings (rather than new objects for new buildings) and specific recovery practices from the demolition contractor's point of view (rather than generic barriers and drivers for reuse for the entire industry). Similar to Chileshe et al. (2018), we did not find evidence for the popular belief that "going green" is an important motivation to recover objects - while the focal project may even be considered a "best practice" due to the (very) high recovery rates. We speculate that this is because we looked at actual instead of self-reported recovery decisions. Changes to building codes, a well-documented barrier for implementing reuse (Gorgolewski, 2008; Hosseini et al., 2015; Kibert et al., 2001), 
played likewise an unimportant role here - most probably because the focal building was only five years old. We argue that our proposition can still cover this issue, since (in)compliance with a new building code impacts the economic demand for an object. Our analysis furthermore suggests that the underlying reasons for recovery are not the same for all building parts (not even per type), but differ per object. Reuse practices may, hence, be better understood in terms of conditions rather than drivers/barriers. Where the latter are more static, conditions depend on specific times and places. That can help in explaining why certain objects are recovered in some projects but not in other ones. An object such as a radiator, for example, is more likely to be recovered when the entire building is relocated than when it is completely demolished (i.e. when condition one is satisfied versus when it may not).

Some caution should be in place though. The proposition we developed is limited to a demolition contractor's decision to recover a building object (or not). It does not predict whether that object is also actually reused. We hence recommend other researchers to set-up a similar study and leave the comfort of their offices for on-site fieldwork so as to better understand object reuse (instead of recovery) from the practitioner's point of view. An ethnographic approach provides an opportunity to obtain intricate details about such phenomena, but may also facilitate closer links between industry and academia (Phelps \& Horman, 2009). Fieldwork in more demolition projects and in other contexts can also help to strengthen the generalizability of our proposition, although we defend the present work by pointing to the large number of units of analysis (i.e. recovery decisions) covered in the focal project and our attempts to corroborate the data.

A more important limitation pertains to the analytic induction method adopted here. This method accounts for necessary and not sufficient conditions for a certain phenomenon. We uncovered three heretofore unknown conditions for building object recovery to occur. It is, however, possible that there are one or more other conditions that must be satisfied before an object is recovered for reuse. Such conditions could, in principle, be present in both positive and negative cases, i.e. objects for which the demolition contractor opted recovery or destruction, respectively, which makes it impossible to discover them. Investigating more recovery decisions for more building objects and in other projects could generally increase the confidence in the robustness of the proposition, but there is no way to completely eliminate this inherent drawback of the method. Bernard and Ryan (2010, p. 332) nevertheless argue that the resulting proposition "allows us to make strong predictions about uncollected cases yet to come" and that "it can do as well as statistical induction" if data collection and analysis was performed systematically. We have therefore 36 | Recovering building objects for reuse (or not) 
purposefully investigated recovery decisions for objects in all six building layers of Brand (1994) and stated the evolving hypothesis in universal terms so that negative cases could be discovered and used to revise it.

The final proposition may thus be used to predict any future recovery decisions. The a posteriorifit of the proposition with the examined data suggests that such decisions are governed by a set of rules. On the surface, it may look like an experienced site supervisor or foreman simply "knows" whether it is best to recover or destruct a building object. We argue that we uncovered some of that tacit knowledge here: the demolition contractor will only engage in recovering a building object when three conditions are met. That is, the firm must answer "Yes" to the following three object-related questions: "is there an economic demand?", "are we sufficiently skilled and disciplined for disassembly?" and "can we control the performance until future integration in a new building?" The evidence makes clear that object recovery only takes place when the firm can answer affirmatively to these three questions (consciously or not) and will not occur when that is not the case.

That insight provides a strong basis to develop evidence-based strategies for promoting object recovery. We argue that such strategies must focus on increasing the likeliness that a demolition contractor (1) identifies economic demands, (2) distinguishes disassembly routines and (3) can control future performance. Since previous studies have argued that system wide changes are necessary to move towards a circular economy (Ghisellini et al., 2016; Kalmykova et al., 2018; Silva et al., 2017), we accordingly deduced strategy suggestions for actors across the entire supply chain that link with the three uncovered conditions (Table 3). A manufacturer could, for example, develop a business model in which it takes back its own products at the end of their functional life (targeting condition one); designers and architects could ensure the disassemble-ability of their envisioned buildings by designing reversible, accessible and limited connections between objects (targeting condition two); and builders could create flexibility in transportation schemes to accommodate uncertain transport movements from salvaged buildings (targeting condition three). In this way, the proposed strategies each try to increase the likelihood that a condition is fulfilled at the moment that a demolition contractor takes a recovery decision.

The proposition presented in this paper, hence, contributes to the body of literature with detailed insights about building object recovery that are strongly grounded in the data, and can guide future studies and practices aimed at increasing the reuse of our natural resources. 
Table 3: Exemplary evidence-based strategies to promote object recovery through targeting three uncovered conditions

\begin{tabular}{|c|c|c|c|}
\hline \multirow{2}{*}{$\begin{array}{l}\text { Actor in } \\
\text { supply chain }\end{array}$} & \multicolumn{3}{|c|}{ Condition for demolition contractor } \\
\hline & $\begin{array}{l}\text { Identify economic } \\
\text { demand }\end{array}$ & $\begin{array}{l}\text { Distinguish disassembly } \\
\text { routines }\end{array}$ & $\begin{array}{l}\text { Control future } \\
\text { performance }\end{array}$ \\
\hline Manufacturer & $\begin{array}{l}\text { Take back manufactured } \\
\text { objects at end of life- } \\
\text { cycle }\end{array}$ & $\begin{array}{l}\text { Produce objects with } \\
\text { reversible, accessible } \\
\text { and limited connections } \\
\text { Archive object detail } \\
\text { (connection) } \\
\text { information to share } \\
\text { with future demolition } \\
\text { contractor }\end{array}$ & $\begin{array}{l}\text { Provide reparation } \\
\text { services } \\
\text { Improve handle-ability } \\
\text { and weather-resistance } \\
\text { properties of objects }\end{array}$ \\
\hline $\begin{array}{l}\text { Designer/ } \\
\text { architect }\end{array}$ & $\begin{array}{l}\text { Investigate demolition } \\
\text { projects nearby new site } \\
\text { for valuable objects } \\
\text { Incorporate (to be) } \\
\text { recovered objects in } \\
\text { designs } \\
\text { Design buildings as } \\
\text { material banks }\end{array}$ & $\begin{array}{l}\text { Design for disassembly } \\
\text { through modularization, } \\
\text { prefabrication and } \\
\text { ensuring reversible, } \\
\text { accessible and limited } \\
\text { connections between } \\
\text { objects } \\
\text { Archive object detail } \\
\text { (connection) } \\
\text { information to share } \\
\text { with future demolition } \\
\text { contractor }\end{array}$ & $\begin{array}{l}\text { Consider storage and } \\
\text { reparation possibilities } \\
\text { in designs through } \\
\text { materialization and } \\
\text { detailing }\end{array}$ \\
\hline Builder & $\begin{array}{l}\text { Source/purchase objects } \\
\text { from salvaged buildings } \\
\text { Publish object needs for } \\
\text { projects in near future } \\
\text { Pursue long-term } \\
\text { collaborations }\end{array}$ & $\begin{array}{l}\text { Modularize and } \\
\text { industrialize production } \\
\text { Use mechanical rather } \\
\text { than chemical } \\
\text { connections } \\
\text { Archive building } \\
\text { sequencing information } \\
\text { to share with future } \\
\text { demolition contractor }\end{array}$ & $\begin{array}{l}\text { Deploy storage and } \\
\text { reparation facilities } \\
\text { Create flexibility in } \\
\text { transport movements to } \\
\text { (new) site to } \\
\text { accommodate supply of } \\
\text { recovered objects }\end{array}$ \\
\hline $\begin{array}{l}\text { Building } \\
\text { owner }\end{array}$ & $\begin{array}{l}\text { Demand the use of } \\
\text { recovered objects }\end{array}$ & $\begin{array}{l}\text { Share existing } \\
\text { conditions information } \\
\text { with demolition } \\
\text { contractor }\end{array}$ & $\begin{array}{l}\text { Allow sufficient time for } \\
\text { demolition works }\end{array}$ \\
\hline $\begin{array}{l}\text { Demolition } \\
\text { contractor }\end{array}$ & $\begin{array}{l}\text { Invite potential buyers } \\
\text { to site (e.g. open house) } \\
\text { Publish information } \\
\text { about objects that could } \\
\text { be recovered online }\end{array}$ & $\begin{array}{l}\text { Train demolition } \\
\text { workers in disassembly } \\
\text { skills } \\
\text { Share best disassembly } \\
\text { practices }\end{array}$ & $\begin{array}{l}\text { Deploy storage and } \\
\text { reparation facilities } \\
\text { Formalize guarantees to } \\
\text { recovered objects }\end{array}$ \\
\hline
\end{tabular}

38 | Recovering building objects for reuse (or not) 


\section{References}

Adams, K. T., Osmani, M., Thorpe, T., \& Thornback, J. (2017). Circular economy in construction: current awareness, challenges and enablers. Proceedings of the Institution of Civil Engineers - Waste and Resource Management, 170(1), 15-24.

Akbarnezhad, A., Ong, K. C. G., \& Chandra, L. R. (2014). Economic and environmental assessment of deconstruction strategies using Building Information Modeling. Automation in Construction, 37, 131-144.

Akinade, O. O., Oyedele, L. O., Ajayi, S. O., Bilal, M., Alaka, H. A., Owolabi, H. A., . . Kadiri, K. O. (2017). Design for Deconstruction (DfD): Critical success factors for diverting end-of-life waste from landfills. Waste Management, 60, 3-13.

Akinade, O. O., Oyedele, L. O., Bilal, M., Ajayi, S. O., Owolabi, H. A., Alaka, H. A., \& Bello, S. A. (2015). Waste minimisation through deconstruction: A BIM based Deconstructability Assessment Score (BIM-DAS). Resources, Conservation and Recycling, 105, 167-176.

Allwood, J. M., Ashby, M. F., Gutowski, T. G., \& Worrell, E. (2011). Material efficiency: A white paper. Resources, Conservation and Recycling, 55(3), 362-381.

Benyus, J. M. (1997). Biomimicry: Innovation inspired by nature. New York, NY: HarperCollins.

Bernard, H. R., \& Ryan, G. W. (2010). Analyzing qualitative data: Systematic approaches. Thousand Oaks, CA: SAGE publications.

Boeije, H. (2009). Analysis in qualitative research. London: Sage publications.

Brand, S. (1994). How buildings learn: What happens after they're built. New York: Penguin.

Chen, X., \& Lu, W. (2017). Identifying factors influencing demolition waste generation in Hong Kong. Journal of Cleaner Production, 141, 799-811.

Cheshire, D. (2016). Building Revolutions: applying the circular economy to the built environment. Newcastle upon Tyne: RIBA Publishing.

Chileshe, N., Rameezdeen, R., \& Hosseini, M. R. (2016). Drivers for adopting reverse logistics in the construction industry: a qualitative study. Engineering, Construction and Architectural Management, 23(2), 134-157.

Chileshe, N., Rameezdeen, R., Hosseini, M. R., Martek, I., Li, H. X., \& Panjehbashi-Aghdam, P. (2018). Factors driving the implementation of reverse logistics: A quantified model for the construction industry. Waste Management, 79, 48-57.

Chini, A. R. (2007). General issues of construction materials recycling in USA. Paper presented at the Sustainable construction, materials and practices: Challenges of the industry for the new millenium, Lisbon.

Chini, A. R., \& Goyal, N. (2011). Country reports USA. Retrieved from Watford:

Coelho, A., \& De Brito, J. (2011). Economic analysis of conventional versus selective demolition-A case study. Resources, Conservation and Recycling, 55(3), 382392.

Coelho, A., \& De Brito, J. (2012). Influence of construction and demolition waste management on the environmental impact of buildings. Waste Management, 32(3), 532-541.

Conejos, S., Langston, C., Chan, E. H. W., \& Chew, M. Y. L. (2016). Governance of heritage buildings: Australian regulatory barriers to adaptive reuse. Building Research \& Information, 44(5-6), 507-519. 
Cooper, D. R., \& Gutowski, T. G. (2015). The environmental impacts of reuse: a review. Journal of Industrial Ecology.

Crowther, P. (1999). Design for Disassembly. BDP environment design guide.

Crowther, P. (2018). Re-valuing construction materials and components through design for disassembly Unmaking Waste in Production and Consumption: Towards the Circular Economy (pp. 309-321): Emerald Publishing Limited.

De Lieto Vollaro, R., Guattari, C., Evangelisti, L., Battista, G., Carnielo, E., \& Gori, P. (2015). Building energy performance analysis: A case study. Energy and Buildings, 87, 87-94.

Diyamandoglu, V., \& Fortuna, L. M. (2015). Deconstruction of wood-framed houses: Material recovery and environmental impact. Resources, Conservation and Recycling, 100, 21-30.

Durmisevic, E. (2006). Transformable building structures: Design for disassembly as a way to introduce sustainable engineering to building design \& construction. Delft University of Technology, Delft.

Ellen MacArthur Foundation. (2013). Towards the circular economy: Economic and business rationale for an accelerated transition. Retrieved from https://www.ellenmacarthurfoundation.org/assets/downloads/publications/Elle n-MacArthur-Foundation-Towards-the-Circular-Economy-vol.1.pdf

Gálvez-Martos, J. L., Styles, D., Schoenberger, H., \& Zeschmar-Lahl, B. (2018). Construction and demolition waste best management practice in Europe. Resources, Conservation and Recycling, 136, 166-178.

Ghisellini, P., Cialani, C., \& Ulgiati, S. (2016). A review on circular economy: the expected transition to a balanced interplay of environmental and economic systems. Journal of Cleaner Production, 114, 11-32.

Gorgolewski, M. (2008). Designing with reused building components: some challenges. Building Research \& Information, 36(2), 175-188.

Graedel, T. E., \& Allenby, B. R. (2010). Industrial ecology and sustainable engineering. Upper Saddle River, NJ: Prentice Hall.

Guy, B., Shell, S., \& Esherick, H. (2006). Design for deconstruction and materials reuse. Paper presented at the CIB Task Group.

Hong, J., Shen, G. Q., Guo, S., Xue, F., \& Zheng, W. (2016). Energy use embodied in China' $\mathrm{s}$ construction industry: A multi-regional input-output analysis. Renewable and sustainable energy reviews, 53, 1303-1312.

Hossain, M. U., \& Ng, S. T. (2018). Critical consideration of buildings' environmental impact assessment towards adoption of circular economy: An analytical review. Journal of Cleaner Production, 205, 763-780.

Hosseini, M. R., Chileshe, N., Rameezdeen, R., \& Lehmann, S. (2014). Reverse logistics for the construction industry: Lessons from the manufacturing context. International Journal of Construction Engineering and Management, 3(3), 75-90.

Hosseini, M. R., Rameezdeen, R., Chileshe, N., \& Lehmann, S. (2015). Reverse logistics in the construction industry. Waste Management \& Research, 33(6), 499-514.

Iacovidou, E., \& Purnell, P. (2016). Mining the physical infrastructure: Opportunities, barriers and interventions in promoting structural components reuse. Science of the Total Environment, 557, 791-807.

40 Recovering building objects for reuse (or not) 
Jin, R., Li, B., Zhou, T., Wanatowski, D., \& Piroozfar, P. (2017). An empirical study of perceptions towards construction and demolition waste recycling and reuse in China. Resources, Conservation and Recycling, 126, 86-98.

Kalmykova, Y., Sadagopan, M., \& Rosado, L. (2018). Circular economy-From review of theories and practices to development of implementation tools. Resources, Conservation and Recycling, 135, 190-201.

Kibert, C. J. (2016). Sustainable construction: green building design and delivery. John Wiley \& Sons.

Kibert, C. J., Chini, A. R., \& Languell, J. (2001). Deconstruction as an essential component of sustainable construction. Paper presented at the CIB World Building Congress, Wellington, New Zealand

Kirchherr, J., Reike, D., \& Hekkert, M. (2017). Conceptualizing the circular economy: An analysis of 114 definitions. Resources, Conservation and Recycling, 127, 221-232.

Kourmpanis, B., Papadopoulos, A., Moustakas, K., Stylianou, M., Haralambous, K. J., \& Loizidou, M. (2008). Preliminary study for the management of construction and demolition waste. Waste Management \& Research, 26(3), 267-275.

Koutamanis, A., Van Reijn, B., \& Van Bueren, E. (2018). Urban mining and buildings: A review of possibilities and limitations. Resources, Conservation and Recycling, 138, 32-39.

Laefer, D. F., \& Manke, J. P. (2008). Building reuse assessment for sustainable urban reconstruction. Journal of Construction Engineering and Management, 134(3), 217-227.

Leedy, P. D., \& Ormrod, J. E. (2010). Practical research: planning and design. New Jersey: Pearson Education.

Leising, E., Quist, J., \& Bocken, N. (2018). Circular Economy in the building sector: Three cases and a collaboration tool. Journal of Cleaner Production, 176, 976-989.

Llatas, C. (2011). A model for quantifying construction waste in projects according to the European waste list. Waste Management, 31(6), 1261-1276.

Löwstedt, M. (2015). 'Taking off my glasses in order to see': exploring practice on a building site using self-reflexive ethnography. Construction Management and Economics, 33(5-6), 404-414.

Mahpour, A. (2018). Prioritizing barriers to adopt circular economy in construction and demolition waste management. Resources, Conservation and Recycling, 134, 216-227.

McDonough, W., \& Braungart, M. (2010). Cradle to cradle: Remaking the way we make things. The North Point Press.

McDonough, W., Braungart, M., Anastas, P. T., \& Zimmerman, J. B. (2003). Peer reviewed: Applying the principles of green engineering to cradle-to-cradle design: ACS Publications.

McDowall, W., Geng, Y., Huang, B., Barteková, E., Bleischwitz, R., Türkeli, S., . . Doménech, T. (2017). Circular economy policies in China and Europe. Journal of Industrial Ecology, 21(3), 651-661.

Musante, K., \& DeWalt, B. R. (2010). Participant observation: A guide for fieldworkers. Rowman Altamira. 
Ness, D., Swift, J., Ranasinghe, D. C., Xing, K., \& Soebarto, V. (2015). Smart steel: new paradigms for the reuse of steel enabled by digital tracking and modelling. Journal of Cleaner Production, 98, 292-303.

Parto, S., Loorbach, D., Lansink, A., \& Kemp, R. (2007). Transitions and Institutional Change: The case of the Dutch waste subsystem. In S. Parto \& B. Herbert-Copley (Eds.), Industrial innovation and environmental regulation. Tokyo: United Nations University Press.

Phelps, A. F., \& Horman, M. J. (2009). Ethnographic theory-building research in construction. Journal of Construction Engineering and Management, 136(1), 5865.

Pink, S., Tutt, D., Dainty, A., \& Gibb, A. (2010). Ethnographic methodologies for construction research: knowing, practice and interventions. Building Research \& Information, 38(6), 647-659.

Pomponi, F., \& Moncaster, A. (2016). Embodied carbon mitigation and reduction in the built environment - What does the evidence say? Journal of Environmental Management, 181, 687-700.

Pomponi, F., \& Moncaster, A. (2017). Circular economy for the built environment: A research framework. Journal of Cleaner Production, 143, 710-718.

Remøy, H., \& van der Voordt, T. (2014). Adaptive reuse of office buildings into housing: opportunities and risks. Building Research \& Information, 42(3), 381-390.

Sauvé, S., Bernard, S., \& Sloan, P. (2016). Environmental sciences, sustainable development and circular economy: Alternative concepts for trans-disciplinary research. Environmental Development, 17, 48-56.

Silva, R. V., De Brito, J., \& Dhir, R. K. (2017). Availability and processing of recycled aggregates within the construction and demolition supply chain: A review. Journal of Cleaner Production, 143, 598-614.

Spradley, J. P. (1979). The ethnographic interview. New York: Holt, Rinehart and Winston. Spradley, J. P. (1980). Participant observation. New York: Holt, Rinehart and Wineston.

Volk, R., Stengel, J., \& Schultmann, F. (2014). Building Information Modeling (BIM) for existing buildings - Literature review and future needs. Automation in Construction, 38, 109-127.

Wang, T., Wang, J., Wu, P., Wang, J., He, Q., \& Wang, X. (2018). Estimating the environmental costs and benefits of demolition waste using life cycle assessment and willingness-to-pay: A case study in Shenzhen. Journal of Cleaner Production, $172,14-26$.

42 | Recovering building objects for reuse (or not) 


\section{Chapter 2}

Information processing for end-of-life coordination: A multiple-case study

Marc van den Berg, Hans Voordijk \& Arjen Adriaanse

Under review

Partly based on scientific conference paper (published):

Van den Berg, M., Voordijk, H., \& Adriaanse, A. (2017). Coordinating reverse logistics in construction: mechanisms to manage uncertainties for various disposition scenarios. Paper presented at the $27^{\text {th }}$ IPSERA Conference, BudapestBalatonfüred. 


\begin{abstract}
To cope with increasing socio-environmental pressures, the construction industry urgently needs theoretically grounded and empirically validated insights for building end-of-life coordination. A predominant framework for understanding coordination activities is provided by information processing theory, which links the structural design of an organization to its information processing needs. Through elaborating this theory, this study aims to explore how demolition contractors coordinate end-of-life strategies. Using a multiplecase study method, data was collected and analyzed from three real-world demolition/deconstruction projects with different end-of-life strategies: a faculty building, a nursing home and a psychiatric hospital. The findings suggest that demolition contractors need to manage building, workflow and environmentalrelated uncertainty through adopting a set of organizational measures that provide information processing capacity. Coordination is more effective when that capacity matches with the information processing needs of the end-of-life strategy at hand: the 'separator' demolition contractor effectively coordinated material recycling and the 'mover' demolition contractor did so for component reuse, but the 'salesman' demolition contractor was ineffective in coordinating element reuse. The conceptual-empirical insights that this paper attempted to offer contribute to a better understanding how coordinating activities at the endof-life phase may enable the start of completely new life-cycle phases.
\end{abstract}

Keywords: Case study; Demolition; End-of-life coordination; Information processing theory (IPT); Reverse logistics; Uncertainty 


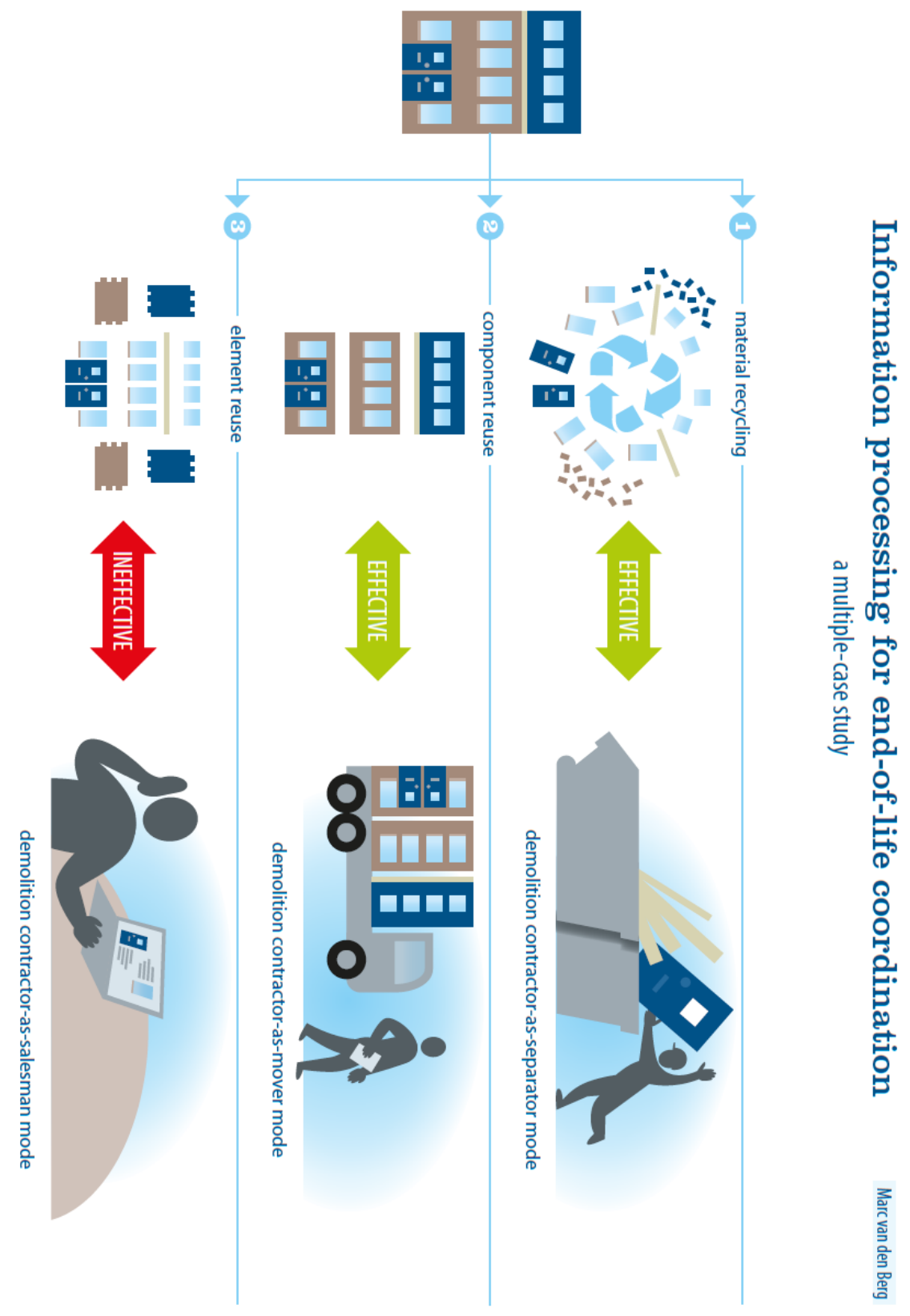




\section{Introduction}

To cope with increasing socio-environmental pressures, the construction industry urgently needs theoretically grounded and empirically validated insights for building end-of-life coordination. While the life of almost any building can be extended indefinitely by technical means, only few receive the monumental or cultural heritage status that actually allows them to be restored time after time (Wassenberg, 2011). Most of our buildings eventually need to be broken down to be adapted, upgraded or replaced. The end-of-life is typically marked by the complete elimination of all parts of a building (Thomsen, Schultmann, \& Kohler, 2011). To dispose of (parts of) a building, demolition contractors traditionally relied on the use of crushing force (bulldozers, wrecking balls, explosives, etc.) and landfilling (Akinade, Oyedele, Ajayi, et al., 2017; Coelho \& De Brito, 2013a). Economic and environmental awareness of the impacts of their activities have more recently led to the recognition of alternative end-of-life strategies such as reuse or recycling. Surprisingly, little scientific attention has been given to the coordination of end-of-life activities.

The quantitative and qualitative significance of those activities is nevertheless considerable. It is estimated that the construction industry produces about $35 \%$ of all solid waste in the world (Llatas, 2011), most of which is generated during demolition activities (Akanbi et al., 2018; X. Chen \& Lu, 2017; Cheshire, 2016; Schultmann \& Sunke, 2007). The construction industry is also the most resource intensive industry in the world, accountable for more than half of the total amount of virgin resources consumed annually and for more than a third of the total global energy usage and associated emissions (Iacovidou \& Purnell, 2016; Ness et al., 2015). Ever-expanding economies and populations of the world are likely to further increase the demand for virgin resources on one hand and the supply of excessive waste on the other hand (Gorgolewski, 2008). Targeting both of these problems, more sophisticated reuse or recycling strategies are needed that make use of waste that would otherwise be lost to landfill sites. This implies that demolition contractors, as key organizations responsible for closing the material loops, need to adopt different coordination mechanisms to deal with the uncertainties associated with such alternative end-of-life strategies.

One fruitful perspective to better understand demolition contractors' coordination activities is offered by information processing theory (IPT). This theory sees uncertainty, defined as a lack of information required to take a decision, as the driver behind organizational activities and decision-making. It posits that the uncertainty arising from a firm's business environment creates information processing needs to which the firm must respond adequately (Galbraith, 1973, 1974; Tushman \& Nadler, 1978). The firm's performance is then

46 | Information processing for end-of-life coordination: A multiple-case study 
a function of the fit between its capacity to process information and the experienced needs to process information. In this view, demolition contractors (embedded in their supply chains) need to gather, interpret and synthesize information for effective end-of-life coordination. The uncertainties associated with different end-of-life strategies, demolition contractors' organizational responses and their (mis)matches are nevertheless poorly understood. The goal of this research is therefore to explore how demolition contractors coordinate end-of-life strategies by elaborating information processing theory.

This paper is structured as follows. It starts with a background on empirical knowledge about end-of-life coordination and on theoretical knowledge about information processing. The methodology section then provides arguments why a theory elaboration approach was most appropriate here and presents our procedures for collecting and analyzing data in three case study projects: a faculty building, a nursing home and a psychiatric hospital. The results section presents the uncertainties faced by demolition contractors (within their supply chains) and their organizational responses. The subsequent discussion section uncovers three sources of uncertainty in end-of-life coordination and discusses the (mis)matches between coordination mechanisms deployed and the uncertainties present in the three projects. The paper concludes with arguments how its conceptual-empirical and inductive-deductive insights help in explaining effective building end-of-life coordination.

\section{Background}

Based on a literature review of empirical and theoretical work, the authors point to two knowledge gaps. Empirical studies, on one hand, lack a sound theoretical perspective that helps to explain how demolition contractors manage uncertainty. Theoretical studies, on the other hand, are deficient in demonstrating end-of-life coordination with data from real-world projects.

\section{Empirical knowledge on end-of-life coordination}

The end-of-life phase of a building is characterized by intensive decision-making and organizational activities concerning the building's future (Akbarnezhad et al., 2014; Chinda, 2016; Thomsen \& Van der Flier, 2009). Buildings are designed for a specified working life, which generally does not exceed $50-60$ years (Laefer $\&$ Manke, 2008). The end-of-life phase follows after a linear sequence of initiative, design, construction and operation/maintenance life-cycle phases. It involves either demolition; the deliberate man-made destruction of a building and its 
parts (Thomsen \& Van der Flier, 2009, p. 651), or deconstruction; the careful dismantling of a building to maximize recovery value (Akinade, Oyedele, Ajayi, et al., 2017). Deconstruction typically requires more labor involvement and longer project durations in comparison with demolition activities, but could also yield profits due to reuse benefits (Pun, Liu, \& Langston, 2006). A building's end-oflife phase may start when a building no longer meets the programmatic needs of its occupants. Other decisive motives for demolition or deconstruction include obsolescence, physical decay, oversupply of similar buildings, quality-of-life (livability) problems or socio-political processes (Thomsen \& Van der Flier, 2011; Wassenberg, 2011). When this is deemed necessary, strategies are determined to either recapture value or dispose of the components, elements and materials arranged in the building.

Possible end-of-life strategies include (in order of increasing level of sustainability): landfilling, recycling and reusing. These strategies particularly differ in the extent to which the original value of the component, element or material is recovered after its primary life (Allwood et al., 2011). The traditional landfilling strategy involves discarding the building parts in landfills without any attempts to recover value, causing space concerns in densely populated areas and potentially contaminating surrounding water courses with toxic chemicals used in buildings (Cooper \& Gutowski, 2015). A main strategy in construction is recycling, in which discarded building parts are reprocessed into raw materials for new products (Iacovidou \& Purnell, 2016). Recycling is often seen as good environmental practice (cf. Coelho \& De Brito, 2013b; T. Wang et al., 2018) as it reduces the demand for new resources and reduces the cost and energy use incurred by landfilling. However, a major problem is that the recycled materials are often used in a lower grade application compared to the initial application and, consequently, that a great proportion of the initially invested energy is lost (Akbarnezhad et al., 2014; Allwood, 2014). Secondary materials may also not be used to substitute virgin materials, but instead drive the production of new lowprice products (Haas, Krausmann, Wiedenhofer, \& Heinz, 2015). Recycled concrete aggregate, for example, can be used as a subbase material but not (yet) as an aggregate in new concrete (Kibert, 2016, p. 377). Since recycling typically reduces the raw material's quality, potential for future uses and economic value, it is also referred to as 'down-cycling' (Chini, 2007). More environmental benefits can be gained through reuse, in which discarded parts are recirculated and used for the same function while the invested embodied energy is preserved (Iacovidou \& Purnell, 2016; Kibert et al., 2001). The well-known 3R waste hierarchy (DoE, 1995) and Lansink's ladder (Lansink, 2017; Parto et al., 2007) hence prioritize reuse over recycling (and recycling over landfilling) in terms of material efficiency. 
Previous studies on these end-of-life strategies have often overlooked coordination activities and instead focused on technical, economic and environmental issues. Recent studies have, for example, discussed a digital tracking and modeling method for steel reuse (Ness et al., 2015), compared economic costs of several demolition/deconstruction techniques (Cha, Kim, \& Kim, 2011; Coelho \& De Brito, 2011; Pun et al., 2006) and estimated the environmental impacts of recycling demolition waste (T. Wang et al., 2018). These works have, subsequently, been informing studies on decision-making methods and tools for selecting the most suitable end-of-life strategy in a given situation (Akinade, Oyedele, Omoteso, et al., 2017; X. Chen \& Lu, 2017; Chinda, 2016). Another group of studies evaluated end-of-life strategies in terms of barriers and enablers. As such, it was found that reuse or recycling activities are more challenging (hence limited in practice) for a number of reasons: the lack of recovery facilities, infrastructure, technology and/or markets; designs without provisions for future dismantling; tight scheduling and budgeting of projects; liability risks for using recovered items; building codes that fail to address reuse; and a lack of standards or guidelines (Hosseini et al., 2014; Hosseini et al., 2015; Iacovidou \& Purnell, 2016; Kibert et al., 2001). Although these studies provided useful contributions, they are deficient in illustrating how different demolition/deconstruction activities are managed in practice.

Effective end-of-life coordination is challenging because of peculiar uncertainties at the project level. As dominant firms in the end-of-life phase of buildings, demolition contractors are responsible for planning, implementing and controlling the flow of products from a salvaged building to a point of further processing (Hosseini et al., 2015; Rogers \& Tibben-Lembke, 1999), like a new construction site. Key activities of which firms need to manage the interdependencies, termed coordination (Malone \& Crowston, 1994), include collecting, inspecting, sorting and further processing of (building) products (Agrawal, Singh, \& Murtaza, 2015). Demolition contractors thereby need to respond to a number of uncertainties in order to realize the expected benefits of different end-of-life strategies. Pun et al. (2006), for example, argued that deconstruction techniques can have a greater profitability (than demolition techniques) but come with increased risk and complexity. Rules and regulations regarding recycling/reuse of building products vary locally and require appropriate organizational responses (Chini \& Goyal, 2011). Demolition contractors also need to be dedicated and engaged as well as to collaborate with stakeholders (Udawatta, Zuo, Chiveralls, \& Zillante, 2015) upstream and downstream its supply chain. Effective reuse, for example, requires that designers of new projects are provided with extra information about any reclaimed products (Gorgolewski, 2008). Uncertainties related to aforementioned barriers 
for reuse and recycling strategies similarly affect demolition contractors' selection and deployment of coordination mechanisms. While managing uncertainty is a relevant and lasting challenge in end-of-life coordination, this has not been investigated empirically. Since the responses of an organization to uncertainty (and the appropriateness thereof) are information processing problems (Winch, 2015), an information processing framework is here seen as most appropriate to guide such systematic reflections.

Previous empirical studies have thus identified end-of-life phase activities and some associated challenges, but lack a sound theoretical framework that helps to explain how demolition contractors coordinate those activities.

\section{Theoretical knowledge on information processing}

A predominant framework to understand organizational behaviour (Levitt et al., 1999) is provided by information processing theory (IPT). This theory essentially views organizations, like demolition contractors, as information processing systems facing uncertainty. The theory stems from the work by Galbraith (1973, 1974,1977 ) and other organization theorists (cf. Tushman \& Nadler, 1978), who related the structural design of an organization to its information processing needs. A central idea is that organizations must process information to reduce uncertainty, but have limited capacity to do so. Information processing is generally defined as the gathering of data, the transformation of data into information, and the communication and storage of information in the organization (Egelhoff, 1991). This is a prerequisite to accomplish internal tasks, interpret the external environment and coordinate diverse activities (Daft \& Lengel, 1986). According to Galbraith (1974), organizations must create information processing capacity according to the amount and type of uncertainty that the organization experiences. While an organization can be over- or underdesigned in its capacity to process information, the theory predicts that the organization is most effective when the information processing needs match with its information processing capacity. Coordination and goal achievement hence depend on organizational design choices.

As such, IPT puts forward a number of mechanisms to plan and design an organization. These mechanisms reflect how an organization structures roles, processes and reporting relationships around the completion of a main task. Galbraith (1974) started by identifying three mechanisms that provide an organization with increasing ability to handle uncertainty: rules and procedures, hierarchy and targets or goals. Rules and procedures are sufficient when tasks are routine and predictable. When exceptions to those rules occur, they are 
resolved by referring the exception to the next hierarchical level. Instead of specifying specific activities, an organization may also set targets or goals to be achieved with employees selecting the behaviours which lead to goals achievement. With increasing uncertainty, the hierarchy becomes overwhelmed and organizations have two options: reducing information processing needs through creating slack resources and/or self-contained tasks, or increasing information processing capacity through investing in vertical information systems and/or creating lateral relations (Galbraith, 1974, 1977). Slack resources decrease the need to process information by lowering performance standards with buffers (e.g. inventories); self-contained tasks do so by organizing the work in small autonomous groups that are supposed to provide a certain output - at the cost of resource specialization. These two mechanisms reduce the need to process information because exceptions are less likely to occur and fewer factors need to be considered when an exception occurs. The other two mechanisms adapt an organization so as to process new information during task performance. Vertical information systems provide information channels to transmit data from the point of origin upward to the decision-maker; lateral relations increase information processing capacity by creating joint decision processes which cut across lines of authority (e.g. direct contact, liaison roles, task forces and permanent teams).

Galbraith's seminal work has been developed further in many conceptual and empirical studies in organization sciences. The conceptual work by Tushman and Nadler (1978), for example, extended the view of organizations as information processing systems with a model for organizational design and structure. They argued that work-related uncertainty originates from different sources (subunit task characteristics, subunit task environment and inter-unit task interdependence) and suggested that organizations should move from mechanistic to more organismic structures when those uncertainties are higher. Daft and Lengel (1986) later contributed to IPT by suggesting that organizations not only process information to reduce uncertainty, but also to reduce equivocality: the existence of multiple and conflicting interpretations about an organizational situation (Weick, 1979). They defined three - other - sources of uncertainty and/or equivocality (technology, interdepartmental relations and the environment) and then proposed and prioritized seven mechanisms with which organizations can respond to these, thereby adding two new mechanisms to IPT: planning (a dynamic process to decide on overall targets and a course of action) and special reports (one-time studies or surveys for a specific problem). Bensaou and Venkatraman (1996) later shifted the focus of IPT from the intraorganizational to an interorganizational level of analysis, drawing attention to dyadic relationships among firms and the role of supportive information 
technologies. Their conceptual framework relates three types of uncertainty (task, partnership and environmental) with structural, process and IT-mediated coordination mechanisms. A recent conceptual contribution to IPT is the identification of six mechanisms for directly reducing sustainability-related uncertainty by Busse, Meinlschmidt, and Foerstl (2016): insourcing, product redesign, prolongation of supplier collaboration, concentration of the supplier base, vertical integration within the supply chain and, finally, reshoring and nearshoring.

Empirical studies have adopted IPT to explain organizational behavior in various contexts. For example, Thomas and Trevino (1993) used a multiple-case study with an IPT lens to demonstrate how organizations process information during strategic alliance building in the healthcare industry and how that is linked to alliance success. Other examples mainly originate from the manufacturing industries and include works on buyer-supplier relationships (Bensaou, 1999; Bensaou \& Venkatraman, 1995), supply chain coordination under varying rates of innovation (Meijboom, Voordijk, \& Akkermans, 2007), cross-functional strategic consensus-building (Feger, 2014), sustainable supply chain management practices (Busse et al., 2016), relational uncertainty in service dyads (Kreye, 2017) and the impact of manufacturing complexity on sustainability (Wiengarten, Ahmed, Longoni, Pagell, \& Fynes, 2017). Empirical IPT studies that deal with construction-related topics are scarcer, but include attempts to quantify uncertainty and equivocality in projects (Chang \& Tien, 2006) and to demonstrate how client organizations consider specific industrialized construction alternatives (Levander, Engström, Sardén, \& Stehn, 2011). The influential work of Winch (2010, p. 315) furthermore views a construction project as a process of reduction of uncertainty through time and illustrates this with case examples. However, previous studies have not viewed end-of-life coordination from an information processing perspective. This makes it unclear what sources of uncertainty, mechanisms and relationships are applicable in this context to explain demolition contractors' organizational activities.

Previous studies that adopted an information processing perspective have thus systematically explained different types of organizational behavior, but lack empirical delineations of end-of-life coordination.

\section{Research design}

This research aims to explore how demolition contractors coordinate end-of-life strategies through elaborating information processing theory. Theory elaboration is an approach that modifies the logic of a general theory in order to reconcile it with contextual idiosyncrasies. This approach is the preferred case 52 | Information processing for end-of-life coordination: A multiple-case study 
research design when a potent general theory exists - such as information processing theory here - that only partially explains a phenomenon of interest (Fisher \& Aguinis, 2017). Positioned in between theory generating and theory testing approaches, theory elaboration has a dual conceptual-empirical as well as inductive-deductive focus so as to explain empirical findings with a refined theory.

\section{Method}

Given the paucity of research on end-of-life coordination, the authors selected a multiple-case study method. This qualitative research method enables to gain indepth insights about the complexity and richness of real-world phenomena over which researchers have little or no control (Eisenhardt, 1989). The case studies were planned to answer how and why demolition contractors process information for end-of-life coordination. Case studies are the preferred method to explore such how and why questions (Yin, 2009, p. 54). A theoretical replication logic was followed to purposefully select three case study projects that dealt with different end-of-life strategies: a faculty building, a nursing home, and a psychiatric hospital (Table 4). These cases were similar in important respects: the buildings were all at the end of their useful life, located in the same country (The Netherlands) and being demolished/deconstructed around the same time, hence subject to the same rules and regulations. The relevant demolition contractors had nevertheless been provided with different specifications how to handle these buildings: enabling material recycling (case I), component reuse (case II), and element reuse (case III). As the first end-of-life strategy is common practice for buildings at the end of their useful life in the Netherlands (and arguably other industrialized countries) (Del Río Merino, Izquierdo Gracia, \& Weis Azevedo, 2010; Tam \& Tam, 2006), this is a 'typical' case in terms of Yin (2009); the second

Table 4: Characteristics of selected demolition/deconstruction (case study) projects

\begin{tabular}{l|l|l|l}
\hline Characteristic & 1: material recycling & 2: component reuse & 3: element reuse \\
\hline Exemplary products & $\begin{array}{l}\text { bricks, steel and } \\
\text { plastics }\end{array}$ & $\begin{array}{l}\text { floor, wall, and façade } \\
\text { parts }\end{array}$ & $\begin{array}{l}\text { doors, handrails and } \\
\text { sinks }\end{array}$ \\
$\begin{array}{l}\text { Building type } \\
\text { faculty building }\end{array}$ & nursing home & psychiatric hospital \\
Gross floor area & $25,000 \mathrm{~m}^{2}$ & $4,500 \mathrm{~m}^{2}$ & $15,000 \mathrm{~m}^{2}$ \\
Location & Netherlands (East) & Netherlands (West) & Netherlands (South) \\
Construction year & 1967 & 2012 & 1973 \\
\hline
\end{tabular}


and third case are 'unique' since those end-of-life strategies are unconventional but usually have lower environmental impacts. The three cases thus provide intriguing opportunities to illustrate how dissimilar end-of-life strategies can result in different information processing needs, capabilities and (mis)matches, and begin to suggest some factors which may be important in the successful coordination of demolition/deconstruction projects.

\section{Data collection}

Data was collected from a wide variety of sources to enable data triangulation and was organized in a case study database (Table 5). The demolition contractor was the prime observational unit of analysis, while the demolition contractor embedded in its supply chain was the explanatory unit of analysis.

Table 5: Overview of data collected per case ( $D C=$ demolition contractor, $G C=$ general contractor, $\mathrm{C}=$ client/principal agent and $\mathrm{T}=$ trader)

\begin{tabular}{|c|c|c|c|}
\hline Data source & I: material recycling & II: component reuse & III: element reuse \\
\hline Interviews & $\begin{array}{l}\text { site supervisor (DC) } \\
\text { project leader (GC) } \\
\text { project manager (C1) } \\
\text { project manager (C2) }\end{array}$ & $\begin{array}{l}\text { site supervisor (DC) } \\
\text { project leader } 1(\mathrm{GC}) \\
\text { project leader } 2(\mathrm{GC}) \\
\text { expedition leader } \\
\text { (GC) } \\
\text { designer (GC) }\end{array}$ & $\begin{array}{l}\text { site supervisor (DC) } \\
\text { project leader (DC) } \\
\text { project leader (C) } \\
\text { commercial advisor } \\
\text { (T) }\end{array}$ \\
\hline Project data & $\begin{array}{l}\text { project schedules, } \\
\text { construction } \\
\text { drawings, artist } \\
\text { impressions }\end{array}$ & $\begin{array}{l}\text { project schedules, } \\
\text { construction } \\
\text { drawings, tender and } \\
\text { contract documents, } \\
\text { cost estimations, e- } \\
\text { mail correspondence }\end{array}$ & $\begin{array}{l}\text { project schedule, } \\
\text { construction } \\
\text { drawings, exemplary } \\
\text { project log book, } \\
\text { access to database } \\
\text { with recovered } \\
\text { building elements }\end{array}$ \\
\hline Site visits & $\begin{array}{l}\text { direct observations, } \\
\text { pictures, unstructured } \\
\text { conversations, notes } \\
\text { (two site visits) }\end{array}$ & $\begin{array}{l}\text { direct observations, } \\
\text { pictures, unstructured } \\
\text { conversations, notes } \\
\text { (one site visit, two } \\
\text { visits to logistics } \\
\text { center) }\end{array}$ & $\begin{array}{l}\text { direct observations, } \\
\text { pictures, unstructured } \\
\text { conversations, notes } \\
\text { (two site visits) }\end{array}$ \\
\hline Other & $\begin{array}{l}\text { news articles, videos, } \\
\text { student report }\end{array}$ & - & $\begin{array}{l}\text { project meeting, web } \\
\text { shop, news articles, } \\
\text { videos, student } \\
\text { report }\end{array}$ \\
\hline
\end{tabular}

54 | Information processing for end-of-life coordination: A multiple-case study 
An essential source of case study information stems from thirteen interviews with key project participants. To enable informants explaining about processing information in their own terms, a semi-structured interview method was chosen. That method balances a structured list of questions to allow comparisons across interviews with the flexibility to modify the order and details of how topics are covered (Bernard \& Ryan, 2010, p. 29). Some key informants were identified during initial discussions with contact persons that led to agreements for collaboration in this research; others were referred to during an interview (snowballing); one site supervisor could only be contacted with the help from the demolition contractor's client as the firm was initially reluctant to share information that could potentially harm them in some way. The researchers specifically sought to interview project participants with first-hand experience in coordinating end-of-life activities at the project level like collecting, inspecting, sorting and further processing. Interviewees were therefore not only selected from the focal demolition firms, but also included managers and other decisionmakers of firms upstream and downstream the demolition contractors' supply chains. The interviews, covering information processing needs and capabilities in the distinct projects, lasted between 60 and 100 minutes each. They were all audio-recorded and transcribed verbatim. A summary of the transcriptions was sent back to the interviewees for verification purposes.

The case studies were also informed by project data, site visits and other data sources. After promising anonymity and confidentiality, all project participants asked agreed to share relevant project documents, although one person did not follow up his promise. The collected documents include, among others, construction drawings (revealing technical building details), schedules (activities and their interdependencies) and tender/contract documents (project and market conditions). In case III, access was also obtained to a new, online database with recovered building elements and the first author was informed about its potentials during a project meeting with an architect and database manager. Furthermore, the (first and second) authors conducted multiple visits to the salvaged buildings (and a logistics center) whilst demolition/deconstruction was going on. Guided by the site supervisors, the researchers closely observed, photographed and wrote down how laborers organized the flow of building products away from the site. During these visits, they had many unstructured conversations with on-site personnel (including the foremen in case I and II), who augmented their understanding of practical issues in end-of-life coordination. Afterwards, the first author summarized and digitalized the lessons learnt from these visits in site visit reports. Finally, some other, secondary data was collected in case I and III: online news articles and short videos on the projects' progress 
made by third parties and two student group reports on decision-making in reverse logistics.

\section{Data analysis}

Data analysis consisted of systematically examining, coding and categorizing the raw data. Even though data collection and analysis are presented as two sections here, because they represent subsequent stages in a research process, chronologically the two activities partly overlapped.

The analysis started with examining the transcripts, project data, site visit notes and other data collected. The first author initially coded the chunks of data with a pattern-matching strategy (Trochim, 1989; Yin, 2009), using codes derived from classical IPT. Particular attention was paid to evidence that did not seem to fit that theory. For example, some information processing efforts of the demolition contractors clearly related to characteristics of the salvaged buildings categories unidentified before. Discussions between all authors, and feedback of other peers, then iteratively led to revisions of the coding scheme. The final coding scheme hence contained codes that originated from the authors' prior theoretical understanding of information processing (e.g. 'slack resources') as well as from the data itself (e.g. 'drawings'), which is in line with a sound theory elaboration approach (Fisher \& Aguinis, 2017).

Coding and recoding was over when sufficient numbers of regularities emerged (Miles \& Huberman, 1994, p. 62). This made it possible to group chunks of coded data in categories. Specifically, recurring codes across the cases inspired the authors to identify six categories (or 'dimensions') of information processing needs in end-of-life coordination. Through pulling together categories that were closely related to each other, three major sources of uncertainty could be formulated. These three sources of uncertainty and six underlying dimensions were critically challenged among all authors until consensus was reached. Similarly, the coordination mechanisms with which demolition contractors respond to information processing needs were linked to concepts from IPT literature where possible, whereas other concepts were newly formulated when the authors collaboratively deemed those concepts inadequate to explain empirical findings. Having established consistent coding and classification, the researchers arranged the data in a case-by-attribute matrix per case (Bernard \& Ryan, 2010, p. 111) and followed the recommendation of Yin (2009, p. 131) to develop detailed, contextually rich, case descriptions. The degree of information processing needs and the (mis)matches between needs and capabilities were (qualitatively) interpreted by and discussed among the authors - with these assessments being reviewed during a workshop with three experts (a CEO and a 56 | Information processing for end-of-life coordination: A multiple-case study 
site supervisor of a demolition contractor and a project manager of a general contractor). The authors also incorporated feedback from other researchers and practitioners from presenting the study at various conferences and workshops. The unfolding insights into information processing practices helped to substantiate empirical findings at a more conceptual level and to elaborate existing theory for end-of-life coordination.

\section{Results}

This section presents the analyses of the three case study projects with different end-of-life strategies: material recycling (case I: faculty building), component reuse (case II: nursing home) and element reuse (case III: psychiatric hospital). Per case, the authors briefly introduce the project and the demolition contractor with its supply chain partners. They then continue with presenting uncertainties at the project level (which are building, workflow and environmental-related) and the demolition contractor's organizational responses to those uncertainties.

\section{Case I: material recycling (faculty building)}

The first case deals with recycling (demolition) materials from the transformation of a large faculty building into 445 (student) studios and a hotel with conference facilities. The demolition contractor involved was selected by a general contractor, based on the lowest bid, for asbestos abatement and soft stripping. The general contractor, in turn, was selected by a developer that would sell the transformed building to two clients after project delivery: one managing the studios and the other the hotel. The demolition contractor's works only leave the load-bearing, concrete structure intact (for subsequent construction) and thereby generated bulky demolition waste, most of which is sent to waste processing firms for recycling. This debris included bricks/cementitious materials, steel, iron, aluminum, plastics, timber and other materials.

Uncertainties arise from the exact type and amount of those materials within the building. There was no accurate material inventory available for the demolition contractor. The firm responded to that by collecting and analyzing construction drawings and making inspection rounds prior to the start of the project. The general contractor provided the firm with the original construction drawings, dating back from the early 1960s but still available. Drawings from later renovations had nevertheless got lost over the years. Some control measurements were taken by the general contractor to verify whether the actual grid sizes, lengths and heights correspond with the (original) drawings. 'It used 
to be a building from the Central Government Real Estate Agency. These buildings have the reputation of having a higher dimensional accuracy [than other types of buildings from that time period]. That also turned out to be the case here' (project leader). The demolition contractor complemented that information with inspection rounds through the building, but its site supervisor argued that 'the exact amount of materials is and remains an educated guess' based on rules of thumb. Because of the large building size, other mechanisms like 3D scans were deemed too costly. The poor accessibility and disassembleability of building elements, as observed on site, suggest that the building was not designed for easy disassembly. The firm therefore aimed to separate the building's infill from the load-bearing structure through conducting soft stripping activities (and to separate the resulting demolition waste per material type) under the supervision of a foreman. Information about some building characteristics, such as the presence of a hidden partitioning wall, is only obtained during these activities and sometimes require adaptation of the ongoing work.

That workflow gives rise to low uncertainties. The demolition contractor aims to establish a fast and cost-efficient indoor waste stream. That started with clearing the four elevator shafts so that these could be used as construction chutes. Soft stripping laborers, working from the upper floor downwards to the ground floor, collect and sort the demolition waste per material type and then throw it through these shafts. On the ground floor, machinery is used to push materials out of the building and to temporarily store them at the (spacious) site. According to the site supervisor, this 'very quick waste stream' is quite predictable, since the soft stripping works are well-understood and similar for all (nine) floors. Uncertainty is increased due to the interdependence of these tasks with the removal of asbestos-containing ductwork, which needs to be done by specialized laborers with their own equipment. The soft stripping crew needs to skim all easy-toremove objects before those laborers can do their job. After the asbestos is removed, the first crew returns and completes the soft stripping. A foreman coordinates these interdependencies through facilitating daily (informal) discussions between the two crews. Similarly, an overall transport planner tries to prioritize and align the material flows from the site to waste processing firms with the transportations from other construction sites.

Environmental uncertainties for recycling materials are low. The general contractor needs to hand over the student studios within the transformed building before the start of the academic year (and the hotel with conference facilities slightly later). This party decided to postpone the reconstruction tasks until the building is completely stripped, for which it closely monitors the demolition contractor's progress with weekly meetings and (almost) daily 58 | Information processing for end-of-life coordination: A multiple-case study 
inspections. Their collaboration is fairly traditional with little electronic data exchange and low levels of mutual trust. On the other end of the supply chain, the demolition contractor has a number of fixed waste processing/recycling firms (specialized per material type) to which it brings the extracted and sorted materials from the building. Concrete and other cementitious materials are crushed on-site and transported to new road construction projects (to serve as foundation material). Annual contracts between the demolition contractor and the different waste processing firms guarantee fixed prices (per ton) to dispose of the different types of (sorted) waste materials. The waste processing firms ultimately reprocess these materials into raw materials for new products.

\section{Case II: component reuse (nursing home)}

The second case deals with the reuse of components generated from deconstructing a nursing home. That was originally built by a general contractor specialized in prefabricated and modularized buildings with a temporary or semipermanent function. The building components that this firm works with include foundation, floor, wall, façade and roof components. The general contractor hired a demolition contractor, based on a long-term partnership, to disassemble the components it had once assembled. The general contractor, subsequently, plans to reuse the disassembled components in a new building project.

A lot of information is available about the nursing home and its modular components. The building was designed to be disassembled after five to seven years. Prefabricated components with standardized sizes and mechanical connections (e.g. nuts and bolts) were used to ease construction and deconstruction. The contract between the building owner (care provider) and general contractor included stipulations about the deconstruction, such as removal costs and the option for the general contractor to repurchase the building. One of the general contractor's project leaders argued that they therefore keep an 'excellent archive' with construction drawings and other documentation of the completed project(s) so that they can 'make a good prediction' about the current situation of the building. The firm shares such information with the demolition contractor to which it outsourced the deconstruction tasks. The site supervisor of that contractor confirmed he received all relevant information, such as 'which foundation was used, which footplate? That is important [to know] for the transport.' That information is complemented with visual inspections of the building, referred to as 'doing your homework.' The disassemble-ability and the availability of accurate information about the building lower information processing needs. 
Deconstruction consists of a number of interdependent tasks that enable the reuse of components. The demolition contractor starts with stripping out all infill to make the components accessible. The reusable components are then labelled according to a deconstruction drawing from the general contractor. That is typically the last revised construction drawing on which the general contractor indicated which components are planned to be reused - and where. A deconstruction drawing tells the demolition contractor, for example, that 'the ones marked blue need to be moved to one construction site and the red ones to another' (designer). For a new construction project, 'you have a drawing with components from the old building. The blue label from the old building is [then] put on the new drawing' (project leader). Based on that drawing, the demolition contractor disassembles the components and organizes their transport. Laborers thereby follow specific handling instructions for disassembling the components and putting them on a truck, such as 'five footplates on one pile' (expedition leader). The demolition contractor's site supervisor argued that the actual transportation tasks were outsourced to a specialized firm 'because of busy time periods.' The firm nevertheless remains responsible for moving components that cannot be reused in a new project directly to a logistics center near the general contractor's main office. The components are stored there until such a new project is found.

These tasks take place in an environment that requires some information processing. To disassemble the modular components without damaging them, knowledge about those components and - particularly - their connections is necessary. The demolition contractor has that knowledge. For more than five years, this is the only party that the general contractor works with for the deconstruction of its buildings. 'He knows our buildings now. He knows how we think, we know how he thinks. That works well' (project leader). Exemplary for the close collaboration is the technical solution that the demolition contractor proposed for disassembling wooden façade components affected by some rot. 'At the top and at the bottom, there are three bolts. [If it rots], you cannot remove those bolts. We proposed to use a drill pipe to drill over it ... so that we do not need a crowbar on the inner side with the risk that ... you get damage' (site supervisor). While the demolition contractor discusses such exceptions with the general contractor, the two parties have established working routines over the years that reduce the need to process information.

\section{Case III: element reuse (psychiatric hospital)}

The third case deals with the reuse of elements (like doors, handrails, sinks, light armatures and ceiling plates) from deconstructing a psychiatric hospital. In this 60 | Information processing for end-of-life coordination: A multiple-case study 
project, the principal agent, a consultancy firm acting on behalf of the building owner, selected a demolition contractor based on a best value (i.e. most social and sustainable) bid. With its bid, the focal firm had committed itself to train and work with temporary workers at a distance to the labor market (e.g. drop-outs, offenders and people with mental disorders) in a job creation program and to deconstruct the building so as to enable the reuse of disassembled building elements. To that end, the principal agent had already developed a database coupled with an online marketplace through which the demolition contractor tried to sell reusable elements. Due to this innovative approach, the works are seen as a 'flagship project' and have received quite a lot of media coverage.

The as-is conditions of the building here give rise to little information processing needs. The principal agent deployed a number of techniques to map those conditions. During inspections, pictures were taken and details of the infill of rooms were written down. This included, for example, the current quality, disassemble-ability, sizes and color of elements like radiators, doors, lighting, ceiling panels etc. These stocktaking efforts took place for each unique room and were then, based on the available construction drawings, multiplied by the total number of rooms. 'You then get quite a plausible image' (project leader). All that information was later entered in an information system that was then made accessible to the demolition contractor. Based on such information, the site supervisor argued that disassembly had originally not been a design concern. For example, chemical connections had been used for the (marble) window sills that now make it impossible to disassemble them without causing damage: 'a pity, because they still have economic value.'

That factor also contributed to the significant uncertainties related to the demolition contractor's workflow. With its bid, the contractor had committed itself to disassemble the entire building and to sell the building elements for future reuse. It was decided to start with soft stripping and disassembly of these elements before the removal of the asbestos containing façade. That made it possible to store the reusable elements indoors, protected from the weather. In different rooms of the salvaged building, the researchers observed piles of disassembled elements, sorted per type and waiting to be sold. The sale of those elements was nevertheless associated with many uncertainties as it was difficult to predict market demand. On forehand, very few potential buyers had been identified. It was also the first time that an online marketplace (web shop), developed by the principal agent, was used to offer elements to the market. The actual demand turned out to be very limited: 'Everything was disassembled by hand, which takes much more hours [than soft stripping with machinery]... I had to earn that back with the sales, but that did not succeed' said the demolition contractor's project leader. Eventually, the demolition contractor did not see any 
other option than to (pay and) dispose of almost all of the - already disassembled - elements.

This relates to a broader set of uncertainties. The construction industry 'is not ready yet' to reuse recovered building elements (project leader). After a telephonic invitation, one trader in (new and recovered) building elements bought just a few elements from the demolition contractor: wooden beams, door dredges, hinges, handrails and a couple of doors. The commercial advisor of that firm argued that 'general contractors still prefer new products.' The elements that this firm bought were 'almost certainly' resold to the private market. The demolition contractor's site supervisor argued that the lack of certifications and warrantees on (particularly) installations also significantly limited sales: 'a ventilation device [as seen on the roof] is still working perfectly. It is already in use for so many years though that no company or project developer will reuse something like that, because insurance companies will never insure it.' Uncertainties also originate from changing building codes, as recovered elements may not meet today's requirements any longer. The principal agent finally speculated that widespread reuse is only possible if there is a large and continuous supply of high-quality recovered elements.

\section{Discussion}

This multiple-case study has adopted a conceptual information processing perspective to explain end-of-life coordination with empirical data from three demolition/deconstruction projects. This section discusses how the resulting insights contribute to the body of empirical knowledge about end-of-life coordination and to theoretical knowledge on information processing. The authors also address the limitations of this work and derive suggestions for future research.

Contributions: uncertainties, organizational responses and their (mis)matches for three end-of-life strategies

This paper identified three major sources of uncertainty that demolition contractors face in coordinating end-of-life strategies: (i) building, (ii) workflow and (iii) environmental uncertainty. These types of uncertainty were observed in all three cases. The authors here tie them with previous research. Building uncertainty is defined as uncertainty stemming from the characteristics of a building. This type of uncertainty is higher when little information is available about as-is conditions (Anil, Tang, Akinci, \& Huber, 2013; Kleemann, Lederer, 
Aschenbrenner, Rechberger, \& Fellner, 2016; Volk et al., 2014) and when the building was originally not designed for easy disassembly (Crowther, 1999; Durmisevic, 2006). Workflow uncertainty originates from the capability to conduct demolition/deconstruction tasks and from their interdependencies. Task capability is influenced by the ability and education of laborers and the availability of tools and equipment. Demolition contractors face more uncertainty with lower task capability. Uncertainty is also higher when those tasks are more interdependent, because performing one task can unexpectedly force adaptation from other tasks in the workflow (Chang, 2001; Chang \& Tien, 2006). Environmental uncertainty arises from the general project context. This type of uncertainty is higher when a demolition contractor needs to make investments specific to the relation with its client that have significantly lower value outside the project, i.e. with higher relational specificity (Unsal \& Taylor, 2011). This type of uncertainty is also higher when market conditions limit retaining the value of building resources with new life-cycles (Adams et al., 2017).

End-of-life strategies differ in the degree of building, workflow and environmental uncertainty posed to the demolition contractor. Based on criteria such as demolition/deconstruction cost, project duration and energy use, a building owner or developer typically mandates reuse, recycling or landfilling of a salvaged building (or parts of it). Depending on the strategy selected, a demolition contractor then faces more or less uncertainty of each one of the three aforementioned sources. For example, building uncertainty is low in the second case (because existing conditions of the building were well known and modularized, prefabricated building components had been used), but this type of uncertainty is higher in the third case (particularly because that building had not been built for easy disassembly). With more uncertainty, the need for increased amounts of information grows and, hence, the need for increasing information processing capacity. The three cases demonstrate that demolition contractors responded differently to the specific uncertainty levels they faced.

In the first case, the demolition contractor - acting as a separator-coordinated material recycling through adopting mechanisms that matched with the experienced information processing needs (Table 6). For example, formal progress reporting to the general contractor and annual contracts with a number of waste processing firms were sufficient to cope with low environmental uncertainties. As another match, the firm set goals to achieve efficient waste streams that are sorted per material type and employed a foreman to solve any related on-site issues (hierarchy) as organizational responses to the building's poor disassemble-ability. These tasks require basic skills and knowledge (i.e. low task capability), but need to be performed before and after removal of asbestos 
Table 6: Match between uncertainties and organizational responses for material recycling (case I)

\begin{tabular}{|c|c|c|c|c|}
\hline $\begin{array}{l}\text { Source of } \\
\text { uncertainty }\end{array}$ & Dimension & $\begin{array}{l}\text { Information } \\
\text { processing } \\
\text { needs }\end{array}$ & $\begin{array}{l}\text { Organizational response } \\
\text { (providing information } \\
\text { processing capacity) }\end{array}$ & Fit \\
\hline \multirow[t]{2}{*}{ 1. Building } & As-is conditions & High & $\begin{array}{l}\text { Collection of drawings (limited } \\
\text { available) } \\
\text { Regular on-site inspections }\end{array}$ & Insufficient \\
\hline & $\begin{array}{l}\text { Disassemble- } \\
\text { ability }\end{array}$ & Medium & $\begin{array}{l}\text { Goals (for material separation) } \\
\text { Hierarchy (to solve on-site } \\
\text { issues) }\end{array}$ & Match \\
\hline \multirow[t]{2}{*}{ 2. Workflow } & Task capability & Low & Rules (for routine tasks) & Match \\
\hline & $\begin{array}{l}\text { Task } \\
\text { interdependencies }\end{array}$ & Medium & $\begin{array}{l}\text { Self-contained tasks (stripping } \\
\text { and asbestos removal) } \\
\text { Lateral relations (daily contact } \\
\text { between teams) } \\
\text { Limited slack resources (on-site } \\
\text { storage) }\end{array}$ & Match \\
\hline \multirow[t]{2}{*}{ 3. Environmental } & $\begin{array}{l}\text { Relational } \\
\text { specificity }\end{array}$ & Low & $\begin{array}{l}\text { Formal reporting (through } \\
\text { meetings) } \\
\text { Little electronic data exchange }\end{array}$ & Match \\
\hline & Market conditions & Low & $\begin{array}{l}\text { Prolongation of buyer } \\
\text { collaboration (through annual } \\
\text { contracts with waste } \\
\text { processors) }\end{array}$ & Match \\
\hline
\end{tabular}

(a self-contained task, like soft stripping). To deal with uncertainties from those interdependencies, the demolition contractor adequately facilitated daily contact between the two teams responsible for soft stripping and asbestos abatement and used the possibility to temporarily store materials on-site (slack resources). A mismatch was nevertheless found for the information processing needs and capacity associated with the as-is building conditions. The demolition contractor acquired the original construction drawings (as the drawings from later renovations got lost) and inspected the building to assess as-is conditions, but these mechanisms were insufficient and could not prevent some adaptations to the workflow (e.g. delays) when unexpected building parts were found.

64 | Information processing for end-of-life coordination: A multiple-case study 
In the second case, the demolition contractor - acting as a mover-coordinated component reuse by adopting mechanisms that matched with the information processing needs it faced (Table 7). Building uncertainties were here low, since the nursing home had been designed and constructed by a general contractor specialized in temporary and semi-permanent buildings with industrialized and modular components - ensuring high disassemble-ability and the abundant availability of construction drawings. Simple mechanisms, such as collecting these drawings and inspecting the building, were therefore sufficient. Specific

Table 7: Match between uncertainties and organizational responses for component reuse (case II)

\begin{tabular}{|c|c|c|c|c|}
\hline $\begin{array}{l}\text { Source of } \\
\text { uncertainty }\end{array}$ & Dimension & $\begin{array}{l}\text { Information } \\
\text { processing } \\
\text { needs }\end{array}$ & $\begin{array}{l}\text { Organizational response } \\
\text { (providing information } \\
\text { processing capacity) }\end{array}$ & Fit \\
\hline \multirow[t]{2}{*}{ 1. Building } & As-is conditions & Low & $\begin{array}{l}\text { Collection of drawings (all } \\
\text { available) } \\
\text { Regular on-site inspections }\end{array}$ & Match \\
\hline & $\begin{array}{l}\text { Disassemble- } \\
\text { ability }\end{array}$ & Low & $\begin{array}{l}\text { Rules (per type, for disassembly } \\
\text { and transport) } \\
\text { Hierarchy (to solve on-site } \\
\text { issues) }\end{array}$ & Match \\
\hline \multirow[t]{2}{*}{ 2. Workflow } & Task capability & Low & Rules (for routine tasks) & Match \\
\hline & $\begin{array}{l}\text { Task } \\
\text { interdependencies }\end{array}$ & Medium & $\begin{array}{l}\text { Outsourcing (for transport) } \\
\text { Slack resources (GC's logistics } \\
\text { center) } \\
\text { Lateral relations (telephonic } \\
\text { contact) }\end{array}$ & Match \\
\hline \multirow[t]{2}{*}{ 3. Environmental } & $\begin{array}{l}\text { Relational } \\
\text { specificity }\end{array}$ & Medium & $\begin{array}{l}\text { Prolongation of supplier } \\
\text { collaboration } \\
\text { Participation in problem- } \\
\text { solving }\end{array}$ & Match \\
\hline & Market conditions & Low & $\begin{array}{l}\text { Prolongation of supplier } \\
\text { collaboration } \\
\text { Prolongation of buyer } \\
\text { collaboration }\end{array}$ & Match \\
\hline
\end{tabular}


handling instructions (rules) for correctly disassembling the reusable façade, floor and other building components are also sufficient to deal with most workflowrelated uncertainties. The actual transport is (as a self-contained task) outsourced to a specialized firm, which enables the demolition contractors to cope with slightly higher uncertainties from task interdependencies. Recovered components are being moved to a new construction site (for direct reuse), but if that is not possible, they are moved to and stored at a logistics centre (slack resources) of the general contractor. Market conditions pose little information processing needs, since the general contractor (that hired the demolition contractor) can easily reuse those components in new projects. Slightly higher uncertainty stems from the demolition contractor's efforts to learn about the general contractor's specific modular system, to which it adequately responded by prolonging the collaboration with fixed contracts.

In the third case, the demolition contractor - acting as a salesman-coordinated element reuse through adopting mechanisms that did not completely match with the experienced information processing needs (Table 8). A particular mismatch was found between the information processing needs resulting from the general project context and the firm's organizational responses. The demolition contractor could adequately cope with building uncertainty through mechanisms such as collecting construction drawings and a stocktaking report and through setting targets for disassembling reusable elements. The firm's information processing capacity was nevertheless not sufficient to deal with environmental uncertainty. The firm lacked information about the actual demand for recovered building elements, yet decided to disassemble the entire psychiatric hospital and offered elements, like doors, handrails and sinks, to the market. Changes in building codes, problems with recertifying and reinsuring recovered elements and end-customer's preferences for new products limited the reuse potential of the disassembled building elements - and all contributed to high information processing needs. The demolition contractor's response was to experiment with a new online marketplace (web shop) and to prolong its collaboration with a trader in building elements, but these mechanisms were insufficient to cope with high levels of environmental uncertainty. Similarly, the firm's organizational responses to the information processing needs originating from task capability were insufficient: laborers with specialized resources were only deployed for disassembly and asbestos abatement (both self-contained tasks), yet not for sales tasks. On-site storage of disassembled elements (slack resources) was furthermore limited to the project duration. As a result of these mismatches, most elements could not be sold and eventually had to be disposed of as demolition waste. 
Table 8: Mismatch between uncertainties and organizational responses for element reuse (case III)

\begin{tabular}{|c|c|c|c|c|}
\hline $\begin{array}{l}\text { Source of } \\
\text { uncertainty }\end{array}$ & Dimension & $\begin{array}{l}\text { Information } \\
\text { processing } \\
\text { needs }\end{array}$ & $\begin{array}{l}\text { Organizational response } \\
\text { (providing information } \\
\text { processing capacity) }\end{array}$ & Fit \\
\hline \multirow[t]{2}{*}{ 1. Building } & As-is conditions & Medium & $\begin{array}{l}\text { Collection of drawings } \\
\text { Regular on-site inspections } \\
\text { Detailed stocktaking report } \\
\text { (principal agent) }\end{array}$ & Match \\
\hline & $\begin{array}{l}\text { Disassemble- } \\
\text { ability }\end{array}$ & High & $\begin{array}{l}\text { (Quality and quantity) targets } \\
\text { Hierarchy (to solve on-site } \\
\text { issues) }\end{array}$ & Match \\
\hline \multirow[t]{2}{*}{ 2. Workflow } & Task capability & High & $\begin{array}{l}\text { Rules (for routine tasks, not } \\
\text { selling) } \\
\text { Job training (as part of job } \\
\text { creation program) } \\
\text { Hierarchy (supervising job } \\
\text { creation program) }\end{array}$ & Insufficient \\
\hline & $\begin{array}{l}\text { Task } \\
\text { interdependencies }\end{array}$ & Medium & $\begin{array}{l}\text { Self-contained tasks (stripping } \\
\text { vs asbestos removal) } \\
\text { Limited slack resources (on-site } \\
\text { storage) }\end{array}$ & Match \\
\hline \multirow[t]{2}{*}{ 3. Environmental } & $\begin{array}{l}\text { Relational } \\
\text { specificity }\end{array}$ & Medium & $\begin{array}{l}\text { Formal reporting } \\
\text { Participation in problem- } \\
\text { solving }\end{array}$ & Insufficient \\
\hline & Market conditions & High & $\begin{array}{l}\text { Much IT use (principal agent's } \\
\text { web shop) } \\
\text { Prolongation of buyer } \\
\text { collaboration }\end{array}$ & Insufficient \\
\hline
\end{tabular}

Overall, the observed (mis)matches in these three cases help to explain why endof-life coordination was sometimes effective and sometimes not. The two demolition contractors that were able to create information processing capacity that matched with their specific levels of uncertainty (case I and II) were more effective in coordinating their focal end-of-life strategies than the demolition 
contractor that was unable to create matching information processing capacity (case III). It is furthermore noted that a demolition firm could have too much information processing capacity, in which case the extra information processing capacity is redundant and costly in terms of time, effort and control, but that this was not found in any of the cases studied. Finally, regardless of the effectiveness, the authors would like to stress here that reuse can be more challenging to coordinate (as outlined above), but that the waste hierarchy prioritizes this strategy over recycling from an environmental impact perspective (Lansink, 2017).

\section{Scientific and practical implications}

This paper offers new opportunities to understand and explain demolition contractors' organizational design choices in the context of end-of-life coordination. As such, it has a number of theoretical and empirical implications. The study firstly advances previous research that identified (self-reported) barriers for reuse and recycling strategies (cf. Chileshe et al., 2016; Hosseini et al., 2015; Iacovidou \& Purnell, 2016) with (actual) insights on how demolition contractors cope with such barriers. It secondly advances research on selecting a specific end-of-life strategy (cf. Akbarnezhad et al., 2014; Chinda, 2016) by demonstrating why those strategies are only effective with the adoption of an appropriate combination of coordination mechanisms. This implies that the information processing perspective this study introduced can help to explain coordination activities that are happening in the real world. But at the same time, the empirical analyses suggested some modifications to the (classical) information processing theory. That is, the study thirdly adds three major sources of uncertainty for the context of end-of-life coordination to IPT literature (cf. Galbraith, 1973; Galbraith, 1974; Tushman \& Nadler, 1978): building, workflow and environmental uncertainty. It fourthly advances literature with relevant, context-specific organizational responses that provide information processing capacity. Two of those responses (collecting drawings and on-site inspections) had not been identified heretofore, yet both resemble with the special reports mechanism proposed by Daft and Lengel (1986).

Practically, this work can inform demolition contractors, and their upstream and downstream supply chain partners, about adopting coordination mechanisms that match with present information processing needs. While practitioners may learn from the detailed case descriptions in themselves, the theoretical IPT perspective can help them to select, implement and reflect on coordination mechanisms for demolition/deconstruction projects. For example, relevant mechanisms can be derived with which the latter salesman demolition contractor 68 | Information processing for end-of-life coordination: A multiple-case study 
could increase information processing capacity: inviting architects/designers to buy elements before they are disassembled to avoid unnecessary work (direct contact); establishing relationships with general contractors willing to reuse elements (long term contracts); deploying a storage facility for disassembled products to extend possible sales times (slack resources); and developing specialized sales teams with specific knowledge and skills about reusable elements (self-contained tasks). Rethinking coordination as information processing activities can thus help practitioners in finding mechanisms with which they can effectively respond to uncertainties at hand.

\section{Limitations and future research}

The theory elaboration research approach followed here helped in explaining significant decision-making and organizational activities for three different building end-of-life phases, but is subject to usual limitations pertaining to this approach. For that reason, several opportunities for validating, refining and complementing this study exist. First, some of the sources of uncertainty and organizational responses identified here have not yet been formalized and operationalized. The authors tried to provide contextually rich and detailed case descriptions, which is preferable when little is known about a certain phenomenon (Yin, 2009), but acknowledge that these are limited to interpretations of the data rather than formal (statistical) measurements. Future research thus needs to develop instruments to quantitatively measure the key constructs identified here and seek to further validate our findings. A follow-up study along the lines of, for example, Premkumar, Ramamurthy, and Saunders (2005) - who explicitly examined the IPT concept of fit or match - would help to strengthen the information processing needs-organizational response relationships suggested in this study. Quantitative approaches can also provide statistical generalizations rather than the analytical ones inherent to case study approaches (Yin, 2013), thus improve this study's external validity. Second, this study may have downplayed the existence of multiple and conflicting interpretations of information. Throughout this paper, the authors have argued that demolition contractors process information to reduce uncertainty, which is in line with most of the organizational literature. However, as noted earlier, Daft and Lengel (1986) were among the first to argue that there is a second reason why (such) firms process information: to reduce equivocality or ambiguity. Future research should explicitly distinguish between these two types of information processing needs with more micro-oriented examinations in order to refine how and why relevant coordination mechanisms are deployed. Third, the focus on information as a critical organizational contingency may have abstracted the 
materiality away. The paper viewed a demolition contractor (embedded in its supply chain) as an information processing system, emphasizing managerial activities aimed at processing information. However, a demolition/ deconstruction project is (also) characterized by physical production. Following the critique of Koskela and Ballard (2006, p. 157), "it is a materials processing system too." Future research can therefore complement our work by adopting different viewpoints, such as based on production management or transaction cost economics, to acquire a more holistic view on end-of-life coordination.

\section{Conclusions}

This conceptual-empirical study explored how demolition contractors coordinate end-of-life strategies through elaborating information processing theory. A demolition contractor, embedded in its supply chain, is conceptualized here as an information processing system facing uncertainty. A cross-case analysis revealed that there are three major sources of uncertainty for end-of-life coordination: building, workflow and environmental uncertainty. End-of-life strategies differ in the degree of building, workflow and environmental uncertainty posed to a demolition contractor. Depending on the specific levels of uncertainty, a demolition contractor responds with adopting a set of organizational measures that provide information processing capacity. Coordination is more effective when the information processing capacity matches with the experienced information processing needs: the separator demolition contractor in the first case was effective in coordinating material recycling; the mover demolition contractor in the second case effectively coordinated component reuse; but the salesman demolition contractor in the third case was ineffective in coordinating element reuse. As such, this multiplecase study answers how and why demolition contractors process information for end-of-life coordination. It is hoped that the theoretically grounded and empirically validated insights this study attempted to offer help in explaining how effectively coordinating activities at the end-of-life phase may enable the start of completely new life-cycle phases.

\section{References}

Adams, K. T., Osmani, M., Thorpe, T., \& Thornback, J. (2017). Circular economy in construction: current awareness, challenges and enablers. Proceedings of the Institution of Civil Engineers - Waste and Resource Management, 170(1), 15-24.

Agrawal, S., Singh, R. K., \& Murtaza, Q. (2015). A literature review and perspectives in reverse logistics. Resources, Conservation and Recycling, 97, 76-92. 
Akanbi, L. A., Oyedele, L. O., Akinade, O. O., Ajayi, A. O., Davila Delgado, M., Bilal, M., \& Bello, S. A. (2018). Salvaging building materials in a circular economy: A BIMbased whole-life performance estimator. Resources, Conservation and Recycling, $129,175-186$.

Akbarnezhad, A., Ong, K. C. G., \& Chandra, L. R. (2014). Economic and environmental assessment of deconstruction strategies using Building Information Modeling. Automation in Construction, 37, 131-144.

Akinade, O. O., Oyedele, L. O., Ajayi, S. O., Bilal, M., Alaka, H. A., Owolabi, H. A., . . Kadiri, K. O. (2017). Design for Deconstruction (DfD): Critical success factors for diverting end-of-life waste from landfills. Waste Management, 60, 3-13.

Akinade, O. O., Oyedele, L. O., Omoteso, K., Ajayi, S. O., Bilal, M., Owolabi, H. A., . . Henry Looney, J. (2017). BIM-based deconstruction tool: Towards essential functionalities. International Journal of Sustainable Built Environment, 6(1), 260 271.

Allwood, J. M. (2014). Squaring the circular economy: The role of recycling within a hierarchy of material management strategies. In E. Worrell \& M. A. Reuter (Eds.), Handbook of Recycling (pp. 445-477). Boston: Elsevier.

Allwood, J. M., Ashby, M. F., Gutowski, T. G., \& Worrell, E. (2011). Material efficiency: A white paper. Resources, Conservation and Recycling, 55(3), 362-381.

Anil, E. B., Tang, P., Akinci, B., \& Huber, D. (2013). Deviation analysis method for the assessment of the quality of the as-is Building Information Models generated from point cloud data. Automation in Construction, 35(Supplement C), 507-516.

Bensaou, M. (1999). Portfolios of buyer-supplier relationships. MIT Sloan Management Review, 40(4), 35.

Bensaou, M., \& Venkatraman, N. (1995). Configurations of Interorganizational Relationships: A Comparison between U.S. and Japanese Automakers. Management science, 41(9), 1471-1492.

Bensaou, M., \& Venkatraman, N. (1996). Inter-organizational relationships and information technology: A conceptual synthesis and a research framework. European Journal of Information Systems, 5(2), 84-91.

Bernard, H. R., \& Ryan, G. W. (2010). Analyzing qualitative data: Systematic approaches. Thousand Oaks, CA: SAGE publications.

Busse, C., Meinlschmidt, J., \& Foerstl, K. (2016). Managing information processing needs in global supply chains: A prerequisite to sustainable supply chain management. Journal of Supply Chain Management, 53(1), 87-113.

Cha, H. S., Kim, K. H., \& Kim, C. K. (2011). Case study on selective demolition method for refurbishing deteriorated residential apartments. Journal of Construction Engineering and Management, 138(2), 294-303.

Chang, A. S. (2001). Work-time model for engineers. Journal of Construction Engineering and Management, 127(2), 163-172.

Chang, A. S., \& Tien, C. C. (2006). Quantifying uncertainty and equivocality in engineering projects. Construction Management and Economics, 24(2), 171-184.

Chen, X., \& Lu, W. (2017). Identifying factors influencing demolition waste generation in Hong Kong. Journal of Cleaner Production, 141, 799-811. 
Cheshire, D. (2016). Building Revolutions: applying the circular economy to the built environment. Newcastle upon Tyne: RIBA Publishing.

Chileshe, N., Rameezdeen, R., \& Hosseini, M. R. (2016). Drivers for adopting reverse logistics in the construction industry: a qualitative study. Engineering, Construction and Architectural Management, 23(2), 134-157.

Chinda, T. (2016). Investigation of factors affecting a construction waste recycling decision. Civil Engineering and Environmental Systems, 33(3), 214-226.

Chini, A. R. (2007). General issues of construction materials recycling in USA. Paper presented at the Sustainable construction, materials and practices: Challenges of the industry for the new millenium, Lisbon.

Chini, A. R., \& Goyal, N. (2011). Country reports USA. Retrieved from Watford:

Coelho, A., \& De Brito, J. (2011). Economic analysis of conventional versus selective demolition-A case study. Resources, Conservation and Recycling, 55(3), 382392.

Coelho, A., \& De Brito, J. (2013a). Conventional demolition versus deconstruction techniques in managing construction and demolition waste (CDW) Handbook of Recycled Concrete and Demolition Waste (pp. 141-185): Woodhead Publishing.

Coelho, A., \& De Brito, J. (2013b). Economic viability analysis of a construction and demolition waste recycling plant in Portugal - part I: location, materials, technology and economic analysis. Journal of Cleaner Production, 39, 338-352.

Cooper, D. R., \& Gutowski, T. G. (2015). The environmental impacts of reuse: a review. Journal of Industrial Ecology.

Crowther, P. (1999). Design for Disassembly. BDP environment design guide.

Daft, R. L., \& Lengel, R. H. (1986). Organizational information requirements, media richness and structural design. Management science, 32(5), 554-571.

Del Río Merino, M., Izquierdo Gracia, P., \& Weis Azevedo, I. S. (2010). Sustainable construction: construction and demolition waste reconsidered. Waste Management \& Research, 28(2), 118-129.

DoE. (1995). Making waste work: A strategy for sustainable waste management in England and Wales. Retrieved from London:

Durmisevic, E. (2006). Transformable building structures: Design for disassembly as a way to introduce sustainable engineering to building design \& construction. Delft University of Technology, Delft.

Egelhoff, W. G. (1991). Information-processing theory and the multinational enterprise. Journal of international business studies, 22(3), 341-368.

Eisenhardt, K. M. (1989). Building theories from case-study research. Academy of Management Review, 14(4), 532-550.

Feger, A. L. R. (2014). Creating cross-functional strategic consensus in manufacturing facilities. International Journal of Operations and Production Management, 34(7), 941-970.

Fisher, G., \& Aguinis, H. (2017). Using theory elaboration to make theoretical advancements. Organizational Research Methods, 20(3), 438-464.

Galbraith, J. R. (1973). Designing Complex Organizations. Addison-Wesley Longman Publishing.

72 | Information processing for end-of-life coordination: A multiple-case study 
Galbraith, J. R. (1974). Organization design: An information processing view. Interfaces, 4(3), 28-36.

Galbraith, J. R. (1977). Organization design: Addison Wesley Publishing Company.

Gorgolewski, M. (2008). Designing with reused building components: some challenges. Building Research \& Information, 36(2), 175-188.

Haas, W., Krausmann, F., Wiedenhofer, D., \& Heinz, M. (2015). How circular is the global economy?: An assessment of material flows, waste production, and recycling in the European Union and the world in 2005. Journal of Industrial Ecology, 19(5), 765-777.

Hosseini, M. R., Chileshe, N., Rameezdeen, R., \& Lehmann, S. (2014). Reverse logistics for the construction industry: Lessons from the manufacturing context. International Journal of Construction Engineering and Management, 3(3), 75-90.

Hosseini, M. R., Rameezdeen, R., Chileshe, N., \& Lehmann, S. (2015). Reverse logistics in the construction industry. Waste Management \& Research, 33(6), 499-514.

Iacovidou, E., \& Purnell, P. (2016). Mining the physical infrastructure: Opportunities, barriers and interventions in promoting structural components reuse. Science of the Total Environment, 557, 791-807.

Kibert, C. J. (2016). Sustainable construction: green building design and delivery. John Wiley \& Sons.

Kibert, C. J., Chini, A. R., \& Languell, J. (2001). Deconstruction as an essential component of sustainable construction. Paper presented at the CIB World Building Congress, Wellington, New Zealand

Kleemann, F., Lederer, J., Aschenbrenner, P., Rechberger, H., \& Fellner, J. (2016). A method for determining buildings' material composition prior to demolition. Building Research \& Information, 44(1), 51-62.

Koskela, L., \& Ballard, G. (2006). Should project management be based on theories of economics or production? Building Research \& Information, 34(2), 154-163.

Kreye, M. E. (2017). Relational uncertainty in service dyads. International Journal of Operations and Production Management, 37(3), 363-381.

Laefer, D. F., \& Manke, J. P. (2008). Building reuse assessment for sustainable urban reconstruction. Journal of Construction Engineering and Management, 134(3), 217-227.

Lansink, A. (2017). Challenging changes: Connecting waste hierarchy and circular economy. Nijmegen: DPN Rikken.

Levander, E., Engström, S., Sardén, Y., \& Stehn, L. (2011). Construction clients' ability to manage uncertainty and equivocality. Construction Management and Economics, 29(7), 753-764.

Levitt, R. E., Thomsen, J., Christiansen, T. R., Kunz, J. C., Jin, Y., \& Nass, C. (1999). Simulating project work processes and organizations: Toward a micro-contingency theory of organizational design. Management science, 45(11), 1479-1495.

Llatas, C. (2011). A model for quantifying construction waste in projects according to the European waste list. Waste Management, 31(6), 1261-1276.

Malone, T. W., \& Crowston, K. (1994). The interdisciplinary study of coordination. ACM Computing Surveys (CSUR), 26(1), 87-119. 
Meijboom, B., Voordijk, H., \& Akkermans, H. (2007). The effect of industry clockspeed on supply chain co-ordination: Classical theory to sharpen an emerging concept. Business Process Management Journal, 13(4), 553-571.

Miles, M. B., \& Huberman, A. M. (1994). Qualitative data analysis: An expanded sourcebook. Thoasand Oaks, CA: Sage.

Ness, D., Swift, J., Ranasinghe, D. C., Xing, K., \& Soebarto, V. (2015). Smart steel: new paradigms for the reuse of steel enabled by digital tracking and modelling. Journal of Cleaner Production, 98, 292-303.

Parto, S., Loorbach, D., Lansink, A., \& Kemp, R. (2007). Transitions and Institutional Change: The case of the Dutch waste subsystem. In S. Parto \& B. Herbert-Copley (Eds.), Industrial innovation and environmental regulation. Tokyo: United Nations University Press.

Premkumar, G., Ramamurthy, K., \& Saunders, C. S. (2005). Information processing view of organizations: An exploratory examination of fit in the context of interorganizational relationships. Journal of Management Information Systems, 22(1), 257-294.

Pun, S. K., Liu, C., \& Langston, C. (2006). Case study of demolition costs of residential buildings. Construction Management and Economics, 24(9), 967-976.

Rogers, D. S., \& Tibben-Lembke, R. S. (1999). Going backwards: reverse logistics trends and practices (Vol. 2): Reverse Logistics Executive Council Pittsburgh, PA.

Schultmann, F., \& Sunke, N. (2007). Energy-oriented deconstruction and recovery planning. Building Research \& Information, 35(6), 602-615.

Tam, V. W. Y., \& Tam, C. M. (2006). A review on the viable technology for construction waste recycling. Resources, Conservation and Recycling, 47(3), 209-221.

Thomas, J. B., \& Trevino, L. K. (1993). Information processing in strategic alliance building: A multiple-case approach. Journal of Management Studies, 30(5), 779-814.

Thomsen, A., Schultmann, F., \& Kohler, N. (2011). Deconstruction, demolition and destruction. Building Research \& Information, 39(4), 327-332.

Thomsen, A., \& Van der Flier, K. (2009). Replacement or renovation of dwellings: the relevance of a more sustainable approach. Building Research \& Information, 37(5-6), 649-659.

Thomsen, A., \& Van der Flier, K. (2011). Understanding obsolescence: a conceptual model for buildings. Building Research \& Information, 39(4), 352-362.

Trochim, W. M. K. (1989). Outcome pattern matching and program theory. Evaluation and program planning, 12(4), 355-366.

Tushman, M. L., \& Nadler, D. A. (1978). Information Processing as an Integrating Concept in Organizational Design. Academy of Management Review, 3(3), 613-624.

Udawatta, N., Zuo, J., Chiveralls, K., \& Zillante, G. (2015). Improving waste management in construction projects: An Australian study. Resources, Conservation and Recycling, 101, 73-83.

Unsal, H. I., \& Taylor, J. E. (2011). An empirical investigation of opportunistic behaviour in project networks and its impact on market efficiency. The Engineering Project Organization Journal, 1(2), 95-106. 
Volk, R., Stengel, J., \& Schultmann, F. (2014). Building Information Modeling (BIM) for existing buildings - Literature review and future needs. Automation in Construction, 38, 109-127.

Wang, T., Wang, J., Wu, P., Wang, J., He, Q., \& Wang, X. (2018). Estimating the environmental costs and benefits of demolition waste using life cycle assessment and willingness-to-pay: A case study in Shenzhen. Journal of Cleaner Production, $172,14-26$.

Wassenberg, F. (2011). Demolition in the Bijlmermeer: lessons from transforming a large housing estate. Building Research \& Information, 39(4), 363-379.

Weick, K. E. (1979). The social psychology of organizing. Reading, MA: Addison-Wesley.

Wiengarten, F., Ahmed, M. U., Longoni, A., Pagell, M., \& Fynes, B. (2017). Complexity and the triple bottom line: an information-processing perspective. International Journal of Operations and Production Management, 37(9), 1142-1163.

Winch, G. M. (2010). Managing construction projects. Chisester: Blackwell Publishing Ltd.

Winch, G. M. (2015). Project organizing as a problem in information. Construction Management and Economics, 33(2), 106-116.

Yin, R. K. (2009). Case Study Research: Design and Methods (4 ed.). Thousand Oaks: Sage.

Yin, R. K. (2013). Validity and generalization in future case study evaluations. Evaluation, 19(3), 321-332. 
76 | Information processing for end-of-life coordination: A multiple-case study 


\section{Chapter 3}

BIM uses for deconstruction practices: Three ethnographicaction insights

Marc van den Berg, Hans Voordijk \& Arjen Adriaanse

Under review

Partly based on scientific conference paper (published) and invited to further develop:

Van den Berg, M., Voordijk, H., \& Adriaanse, A. (2018). Supporting deconstruction practices with information systems using ethnographic-action research. Paper presented at the $34^{\text {th }}$ ARCOM Conference, Belfast, UK. 


\begin{abstract}
Socio-environmental pressures motivate the construction industry to adopt working practices that enable the reuse of building elements. Deconstruction, as an alternative to demolition, is a major lever for more efficient resource management and enables closed-loop material cycles. Building Information Modeling (BIM) may provide potential benefits for deconstruction practices, but implementations are scarce because of a limited understanding about the information that deconstruction workers require on site and about the potentials of BIM-based methods for deconstruction. This research has therefore two goals: identifying how information is used during deconstruction activities on site, and exploring how BIM-based methods can support those activities. Through applying an ethnographic-action research methodology during the deconstruction of a nursing home, three BIM uses are iteratively developed: (I) 3D existing conditions analysis, (II) reusable elements labeling, and (III) 4D deconstruction simulation. Insights are provided - firstly - into deconstruction routines and the tacit knowledge that deconstruction workers possess and use to deal with these routines, and - secondly - into how three BIM-based methods supported the practitioners in their ongoing project works. This study thereby suggests new possibilities to support deconstruction management through leveraging the potentials of BIM.
\end{abstract}

Keywords: BIM; construction site; Deconstruction; Ethnographic-action research; Reuse 


\section{Introduction}

Resource scarcity, sustainability challenges and stringent policies motivate the construction industry to adopt working practices that enable the reuse of building elements. Deconstruction management is a major lever to close material cycles. As an alternative to knocking down buildings with crushing force, Kibert (2016, p. 480) describes deconstruction as "construction in reverse" in which a building is disassembled for the purpose of reusing its elements. Deconstruction has been advocated for its environmental benefits as the practice prevents the extraction of virgin materials, cuts the associated release of greenhouse gases, saves energy and water consumption and avoids solid waste disposal (Diyamandoglu \& Fortuna, 2015). It may also provide more financial benefits than demolition, but comes with increased complexity and risks that deter demolition contractors from its adoption (Pun et al., 2006). A shift from demolition to deconstruction nevertheless seems imperative given that end-of-life activities generate one of the largest single waste streams worldwide (Cheshire, 2016). To further deconstruction and reuse, local project routines and possibilities to practically support those routines need to be understood much better.

Recent advances in digital technologies provide new opportunities to support deconstruction projects. Technologies that are commonly reported in construction management research include 3D laser scanning, mobile computing, robotics and - particularly - Building Information Modeling (BIM) (Alsafouri \& Ayer, 2018), the focal technology in this paper. BIM technologies allow to represent physical and functional characteristics of a facility in a virtual model (Eastman et al., 2011; Succar, 2009). Such models can be linked with schedule, cost or environmental information. The resulting BIM uses are relevant for different industry stakeholders as it offers them new ways to predict, manage and monitor projects (Wong \& Zhou, 2015). A "BIM use" is seen here as a method of applying Building Information Modeling to achieve one or more specific objectives (Kreider \& Messner, 2013). Promising benefits from the use of BIMbased methods have stimulated the global uptake of the technology. The potentials for end-of-life activities have been largely ignored so far (Akinade, Oyedele, Omoteso, et al., 2017), with BIM rarely being implemented for existing buildings (Volk et al., 2014; Won \& Cheng, 2017). Research into end-of-life activities focuses on predicting waste or measuring deconstructability during the design and frequently lacks empirical reflections. Consequently, little is known about how BIM-based methods can support real-world deconstruction activities.

Developing such methods foremost depends on a detailed understanding of the information that deconstruction workers use at the site. Winch (2015) argues that projects are inherently uncertain, which requires practitioners to process 
information throughout the different project phases. The workers thereby appear to rely heavily on practice-based learning (Löwstedt, 2015) and the majority of their constructability knowledge is not explicit but implicit (Phelps \& Horman, 2009). Dominant construction methodologies, largely rooted within the positivist tradition, are limited in capturing the tacit knowledge, materials and socialities implicated in the site-based work practices of these practitioners (Pink et al., 2010). Few studies have sought to understand the situated body of construction knowledge that deconstruction workers possess, and which is mobilized mainly in practices on site. The possibilities to leverage BIM to its full benefits are thus limited by a lack of understanding on how deconstruction workers create, exchange and communicate information and what artifacts they thereby use (Hartmann, Fischer, \& Haymaker, 2009).

This study's research goal is therefore twofold: identifying how information is used during deconstruction activities on site, and exploring how BIM-based methods can support those activities. To that end, this paper first reviews literature about deconstruction practices and BIM-based methods before presenting a rather unique ethnographic-action research methodology. Following that methodology, we discuss information usages in an actual 'best practice' deconstruction project from the deconstruction workers' point of view and elaborate on the iterative development and implementation of BIM-based methods in that project. The paper concludes with critical reflections and handson recommendations for practitioners.

\section{Review on leveraging BIM for deconstruction}

A review of the state-of-the-art literature points to two knowledge gaps: an (ethnographic-oriented) lack of knowledge about the information that deconstruction workers use on site, and an (action-oriented) lack of knowledge about how BIM-based methods could support their practices.

\section{Deconstruction activities on site}

Deconstruction of a building at the end of its service life is emerging as an alternative to conventional demolition. The process of demolition produces enormous amounts of materials that in most countries results in a significant waste stream (Chini \& Bruening, 2003). In Europe, around 820 million tons of construction and demolition waste is generated on a yearly basis, which amounts up to around $46 \%$ of the total waste (Gálvez-Martos et al., 2018). That waste is rather heterogeneous as it comprises various materials depending on the original

80 | BIM uses for deconstruction practices: Three ethnographic-action insights 
function and location (Lansink, 2017, p. 193). It is increasingly recognized that those materials have their own specific life cycles that interact dynamically in space and time (Pomponi \& Moncaster, 2017). Some of the building elements may, accordingly, have reuse potential and can substitute raw materials during the construction of new buildings. Conceptualizing a building as a material bank implies that a different building removal method must be adopted at the end of the structure's life-cycle: deconstruction, the systematic disassembly of a building to maximize recovered materials reuse and recycling (Iacovidou \& Purnell, 2016). Deconstruction is a crucial step towards closing material loops, because it makes reusable construction materials available and simultaneously reduces the need to extract virgin resources for new buildings (Diyamandoglu \& Fortuna, 2015). That can unlock new economic opportunities for the demolition contractor. At least, in theory.

In practice, deconstruction is faced with several challenges. Kibert (2016, p. 390) describes closing material flows even as "the most challenging of all green building efforts." Deconstruction has a lower use of mechanical equipment compared to conventional demolition, but is more labor intensive and takes longer. As a direct consequence, labor costs can be up to six times higher for the same building (Coelho \& De Brito, 2011) and total costs can be $17-25 \%$ higher (Dantata, Touran, \& Wang, 2005). That is because the ease and speed of deconstruction are hindered by the design and techniques used during construction (Iacovidou \& Purnell, 2016). The use of chemical connections between building elements (e.g. in-situ cast concrete joints) instead of mechanical ones (e.g. screws or bolts), for example, increases costs and limits the practicability of deconstruction. This becomes particularly challenging when the project is under time pressure from landowners (Allwood et al., 2011; Cooper \& Gutowski, 2015), for example because it is part of constructing a new structure. Furthermore, the very long lifespan of buildings with potentially changing ownership and differences in deterioration rates generally results in significant uncertainty regarding the actual composition of buildings (Hosseini et al., 2015; Schultmann \& Sunke, 2007). It is also very challenging to coordinate the supply of recovered elements with demand (Gorgolewski, 2008), that is, to make sure that those elements are delivered at the right time and place. Other practical challenges in deconstruction and reuse include: a lack of building codes, material standards and guidelines; the existence of hazardous substances in buildings (e.g. asbestos); and consumer preferences, taste and perceptions (Iacovidou \& Purnell, 2016).

To deal with such challenges, deconstruction workers process project information on a day-to-day basis. Little is known about their information usages though. Site activities have only been described in general terms, for example as 
basic deconstruction steps (Chini \& Bruening, 2003, p. 5; Gálvez-Martos et al., 2018, p. 173), required tools and equipment (Coelho \& De Brito, 2013a, pp. 146154) or on-site sorting of waste practices (Poon, Yu, See, \& Cheung, 2004). Traditional research methods are inadequate to capture complex interactions, particularly the tacit knowledge that practitioners deploy in local project routines. For example, Koutamanis et al. (2018, p. 35) noted that demolition experts "appear to be experts in value recognition, too" and Kourmpanis et al. (2008, p. 271) commented that they know to recover valuable materials in time or else "'informal recyclers' (i.e. thieves) may do it for them." Such detailed insights are scarce as it is challenging to fully understand what deconstruction workers know. Ethnographic methods are well suited to that end, because they build theory through closely observing practitioners' everyday practical activities, common beliefs, values and discourses in which their knowledge is manifested (Pink et al., 2010). There are very few ethnographic studies for the construction industry, but recent exemplary applications cover the adoption of interorganizational information and communication technology (Adriaanse, Voordijk, \& Dewulf, 2010a), planning and safety practices at construction sites (Löwstedt, 2015) and a reflexive thinking process during a professional conflict (Grosse, 2018). With even less ethnographic-oriented research focused on the end-of-life phase, little is known about how practitioners use information during deconstruction activities on site.

\section{Potentials of BIM-based methods}

BIM has become the dominant information technology paradigm in construction research and practice (Eastman et al., 2011; Gu \& London, 2010; Succar, 2009). With BIM technology, an accurate virtual model of a building can be digitally constructed (Azhar, 2011). Such a digital prototype can be analyzed, priced, interpreted and procured by distinct organizations over different life-cycle stages (Shen, Zhang, Shen, \& Fernando, 2013). Aligning BIM-based methods with project routines can beneficially support construction management activities (Hartmann, Van Meerveld, Vossebeld, \& Adriaanse, 2012). Previous studies demonstrated, for example, that practitioners benefitted from 3D representations of the model in evaluating design proposals (Van den Berg, Hartmann, \& De Graaf, 2017) or from 4D process visualizations to coordinate site activities (Olde Scholtenhuis, Hartmann, \& Dorée, 2016). Other BIM uses are automated cost estimation, drawing production and engineering analyses (Hartmann, Gao, \& Fischer, 2008; Sacks, Koskela, Dave, \& Owen, 2010). The most frequently reported benefits of BIM implementations related to cost reduction, time savings and productivity increases throughout projects (Bryde et al., 2013).

82 | BIM uses for deconstruction practices: Three ethnographic-action insights 
Due to such promising benefits, academic and practical interest in BIM has been growing over the past decades - particularly during design, planning and construction phases.

The potentials of BIM uses for the end-of-life phase are still underexplored. In that regard, there are two major streams of research targeting the generation of demolition waste. One stream of research focused on BIM-based methods to prepare for demolition or deconstruction. For example, Cheng and Ma (2013) developed an information system for waste estimation and planning, which can extract material and volume information from a BIM model. Other examples include a BIM-based framework to assess the economic and environmental impact of alternative deconstruction strategies (Akbarnezhad et al., 2014) and a deconstruction waste management system to identify, measure and plan for recyclable materials (Ge et al., 2017). Another stream of research has proposed methods that measure the deconstructability of a building during the design stage. Exemplary studies covered "essential functionalities" for a BIM-based deconstruction tool (Akinade, Oyedele, Omoteso, et al., 2017) and systems that mathematically assess deconstructability and salvage performance (Akanbi et al., 2018; Akinade et al., 2015). While these works contribute with important insights into BIM uses for deconstruction issues, they are limited to pre-demolition phases.

Little is known about how BIM-based methods can support site activities in actual deconstruction projects. A literature review of the potentials of BIM for construction and demolition waste management revealed 23 BIM uses for planning, design, construction and operation phases, but no "specific BIM uses that can be implemented in the demolition phase" (Won \& Cheng, 2017, p. 8). Similarly, the influential BIM Handbook of Eastman et al. (2011) does not identify the demolition contractor as a potential user of BIM, nor do popular BIM maturity models (Sebastian \& Van Berlo, 2010; Siebelink, Voordijk, \& Adriaanse, 2018; Succar, 2009). In the same line, Volk et al. (2014) found that BIM implementations for existing buildings have been scarce, particularly due to challenges related to high modeling efforts, updating of information in BIM and handling of uncertain data. Davies and Harty (2013) also argue that construction site management work is still dominated by paper in the form of drawings, notes and forms for capturing information. Very few studies have explored whether such paperbased practices could be replaced or complemented with BIM-based methods, for example through adopting an exploratory action research approach. With few action-oriented reflections about BIM uses in demolition or deconstruction projects available, little is known about how deconstruction workers could benefit from BIM during their works on site. 


\section{Ethnographic-action research methodology}

This research has a dual goal: identifying how information is used during deconstruction activities on site, and exploring how BIM-based methods can support those activities. An ethnographic-action research methodology was adopted to study the potentials of three BIM uses for deconstruction. This methodology integrates techniques from both ethnographic and action research approaches (Hartmann et al., 2009). Ethnography, on one hand, has traditionally been deployed by anthropologists to describe a human culture from a native's point of view (Spradley, 1979, 1980). Action research, on the other hand, aims at building and testing theory within the context of solving an immediate practical problem in a real setting (Azhar, Ahmad, \& Sein, 2009). Researching and developing information systems (here: BIM-based methods) can benefit from both methodologies: ethnography allows gaining a detailed understanding of the practitioners' information uses and through action research it is possible to program and customize new information systems. Hartmann et al. (2009) describe the ethnographic-action research methodology as an iterative, fourstage research cycle of (1) 'ethnographic observations', (2) 'identification of work routines', (3) 'information system development' and (4) 'information system implementation on the project'. The methodology is applied here to 'BIM uses' for deconstruction: the first two steps of the iterative cycle are more ethnographic-oriented and relate to the objective(s) of a BIM use, whereas the second two steps are more action-oriented and relate to the method of applying BIM. We consider both parts equally important for providing new scientific insights.

Ethnographic and action research techniques were, accordingly, applied to a realworld project in the Netherlands: the deconstruction of a nursing home. Since most buildings are (still) demolished instead of deconstructed, the focal project is rather unique and can be viewed as a 'best practice' because of the large numbers of building elements that were planned to be reused. The nursing home had a total gross floor area of approximately $2,400 \mathrm{~m}^{2}$ and consisted of two stories with mostly individual bedrooms and some shared bathrooms and kitchens/living rooms. It had been built by a system builder, a general contractor that specialized in modular and prefabricated buildings. Like most of the buildings the firm constructs, the nursing home served a temporary function and, consequently, has had a relatively short service life (5-6 years). At the end of the nursing home's life-cycle, the system builder planned to take back and reuse almost all elements belonging to the "skin" and "structure" building layers (Brand, 1994), like façades, floors, columns, roofs and wind bracings. These building elements can be mixed and matched well for use in another project due to their modular sizes and standardized interfaces. Here, the system builder planned to 84 | BIM uses for deconstruction practices: Three ethnographic-action insights 
reuse elements of the nursing home for the construction of a school in another part of the country. To that end, it subcontracted a demolition contractor (with which the firm has a long-term, strategic partnership) to disassemble and transport those elements.

Data collection and analysis were conducted mostly in parallel, following the iterative nature of the ethnographic-action research methodology. The system builder and demolition contractor only granted the first mentioned researcher access to the site after he passed for an official health and safety exam (VCA$\mathrm{VOL}$ ) and arranged insurance coverage for personal accidents on site. This researcher then made participant observations for a total of about 250 hours, visiting the site on a nearly daily basis. He thereby sought to identify the deconstruction workers' information requirements by observing as an "active participant" (Spradley, 1980, p. 60) or, in other words, by doing what they were doing. As such, the researcher worked amongst the deconstruction workers to participate in the regular deconstruction activities and other project routines, including: installing construction fencing, moving things around, removing ceiling panels, sorting materials, cutting cables and rigging/hoisting heavy loads. At the same time, the researcher retained an analytical position so that through reflection and analysis he could later describe the information usages during the deconstruction activities. He kept a field diary to write down important observations and took over 800 pictures and movie clips, which is in line with "recent innovative approaches to doing ethnography" (Pink et al., 2010, p. 649). $\mathrm{He}$ also collected many project documents from the system builder and demolition contractor, like the (original) construction drawings and the deconstruction schedule. Some digital building information was later used to develop the three BIM-based methods, which was mostly done off-site. The implementations of those BIM-based methods were all audio-recorded (and later transcribed verbatim) and the researcher made detailed notes about the practitioners' interactions with the systems. All data was stored in a database (with the hand-written notes being digitalized). To ensure rigor, all researchers regularly convened throughout the research process to reflect on the potentials of the BIM-based methods under development. Preliminary findings were furthermore reviewed by three managers of the demolition contractor and system builder (a director, site supervisor and project leader) during a workshop and presented at a scientific conference. The valuable feedback of these practitioners and academics subsequently helped in writing the following explanatory account about how deconstruction projects could be supported with BIM. 


\section{Results: BIM uses for deconstruction}

Deconstruction activities can be dirty, dusty and dangerous. Those activities were initially not supported with BIM (or other digital technologies) in the focal project. That changed here with the iterative improvement of three new BIM uses for deconstruction (Table 9-11): (I) 3D existing conditions analysis; (II) reusable elements labeling; and (III) 4D deconstruction simulation.

\section{BIM use I: 3D existing conditions analysis}

An early ethnographic observation was that the site supervisor marked the likely locations of wind bracings through spraying graffiti on some of the interior walls. This was done "because the walls would otherwise be cut open with too much brute force," told the man when he sprayed a large cross and two vertical lines in the demolition contractor's house style color. Unlike the gypsum boards, insulation and metal-studs of the interior walls, the wind bracings were planned to be reused. "Damage to them must be prevented." The operators of the mini excavator must hence be informed which walls require more care during the mechanical demolition. Only after they cut a wall open with the mini excavator, wind bracings (may) become visible; as one of the last steps in the project these

Table 9: Iterative improvement of "3D existing conditions analysis"

\begin{tabular}{|l|l|l|l|}
\hline Research stage & Iteration 1 & Iteration 2 & Iteration 3 \\
\hline $\begin{array}{l}\text { Ethnographic } \\
\text { observation }\end{array}$ & $\begin{array}{l}\text { Site supervisor sprays } \\
\text { graffiti on interior } \\
\text { walls to indicate } \\
\text { location wind } \\
\text { bracings }\end{array}$ & $\begin{array}{l}\text { The building is not } \\
\text { completely modular: } \\
\text { a few 'specials' }\end{array}$ & $\begin{array}{l}\text { (To be) recovered } \\
\text { elements have } \\
\text { specific destinations }\end{array}$ \\
\hline $\begin{array}{l}\text { Identification of work } \\
\text { routines }\end{array}$ & $\begin{array}{l}\text { Machine operator } \\
\text { destructs walls, must } \\
\text { be careful not to } \\
\text { damage wind } \\
\text { bracings }\end{array}$ & $\begin{array}{l}\text { End-of-life strategy } \\
\text { of 'specials' indicated } \\
\text { on 2D drawings }\end{array}$ & $\begin{array}{l}\text { Public (online) } \\
\text { sources enable } \\
\text { preparations to 'get a } \\
\text { feeling' about } \\
\text { (destination) building }\end{array}$ \\
\hline $\begin{array}{l}\text { Information system } \\
\text { development }\end{array}$ & $\begin{array}{l}\text { Upgrading formats of } \\
\text { preexisting building } \\
\text { documentation of 3D } \\
\text { discipline models }\end{array}$ & $\begin{array}{l}\text { Modeling/visualizing } \\
\text { global shapes, } \\
\text { locations and } \\
\text { connections in 3D }\end{array}$ & $\begin{array}{l}\text { Determining viewing } \\
\text { settings detailed 3D } \\
\text { (destination) model }\end{array}$ \\
\hline $\begin{array}{l}\text { Information system } \\
\text { implementation on } \\
\text { the project }\end{array}$ & $\begin{array}{l}\text { Brief demonstration } \\
\text { of discipline 3D } \\
\text { model to foreman to } \\
\text { show building details }\end{array}$ & $\begin{array}{l}\text { Discussion of specials } \\
\text { with reference to 3D } \\
\text { model (foreman and } \\
\text { site supervisor) }\end{array}$ & $\begin{array}{l}\text { Demonstration of 3D } \\
\text { destination model (to } \\
\text { prepare for } \\
\text { upcoming works) }\end{array}$ \\
\hline
\end{tabular}

86 | BIM uses for deconstruction practices: Three ethnographic-action insights 
could then be disassembled manually for reuse. Later observations also revealed that, even though the nursing home was designed and built as a deconstructable building, not all floors and façades had modular sizes but that there were some "specials" that required different deconstruction methods. The participant observations illustrate that deconstruction workers determine the appropriate deconstruction method based on information about the building.

Deconstruction workers could benefit from a BIM-based method to analyze the existing building conditions. The site supervisor used two floor plans that were provided by the system builder. Since the wind bracings were placed perpendicularly to the floors, they are not clearly visible on a floor plan. Their locations were therefore indicated with thick, red lines on these $2 \mathrm{D}$ drawings. To spray graffiti on the correct walls, the site supervisor must thus be capable of reading those drawings. These particular ones did, however, not indicate the walls in which the wind bracings were hidden. This made it more difficult to judge the actual situation and determine which walls in fact contained those elements. For a couple of walls, the site supervisor consequently sprayed an additional question mark to signal that it was not entirely clear whether those walls contained any wind bracings. Deconstruction workers considered that "a practical solution" for the lack of accurate building information, since it helps in protecting building elements with reuse value. Routines like this one suggest that deconstruction workers particularly need information about the existing building conditions to know where to shift their attention from destructing to recovering elements. The researcher consequently proposed to make such information virtually available in three dimensions.

A 3D model of the existing situation was then iteratively developed based on preexisting building information. The design of the nursing home had initially (primarily) been represented by $2 \mathrm{D}$ drawings, since the system builder had not yet fully adopted BIM when the firm designed and built the nursing home. The researcher had, however, also received two discipline models, each containing (only) parts of the foundations, floors, roofs, columns and wind braces. Since the models were created in an outdated version of popular BIM software and the demolition contractor did not have a correct license, the researcher upgraded both models to a current version. One of the models also contained a façade object library (though incomplete). The researcher decided to use that one as a basis to iteratively model and visualize the (then) existing conditions, i.e. a complete 3D model yet without interior walls, installations and infill. Particular attention was paid to modeling the correct locations, connections and outer shapes of elements that were planned to be recovered for reuse, but less to nongeometrical data attributes. The researcher also requested (and received) a detailed 3D (BIM) model of the school that was planned to be constructed with 
elements of the nursing home. Development of that "destination model" was limited to changing and updating 3D viewing settings.

The BIM-based method provided deconstruction workers insights into the existing building conditions. After a first demonstration of a discipline model with different viewing settings, the foreman and the site supervisor noted that some existing building parts, like the wind bracings, were better visible in 3D. "With $2 \mathrm{D}$ we also find our way, but in 3D it works a bit nicer," argued the foreman. That is, it allows to view the building (details) from any angle. Through viewing the global shapes, locations and connections of modeled elements, deconstruction workers appeared to understand the (de)construction sequences. "You can simply see it over there," pointed the site supervisor to the laptop screen during a later discussion about two floors connected with a staircase (Figure 2). Unlike the 2D drawings (without staircase), the 3D building model showed that the upper floor had a recess, but the lower one not. "So the staircase is just assembled on top of that one," noticed the site supervisor. They both concluded that the destination (i.e. storage or disposal) for the upper, smaller floor had to be discussed with the system builder, but that the lower one had to be disassembled for reuse in the school building. After the researcher showed a 3D model of that school, the site supervisor continued that $3 \mathrm{D}$ visualizations could help him to "get a feeling about" and "prepare better" for a certain project. Instead of searching for public (online) information about a to-be-demolished building, he hypothesized as

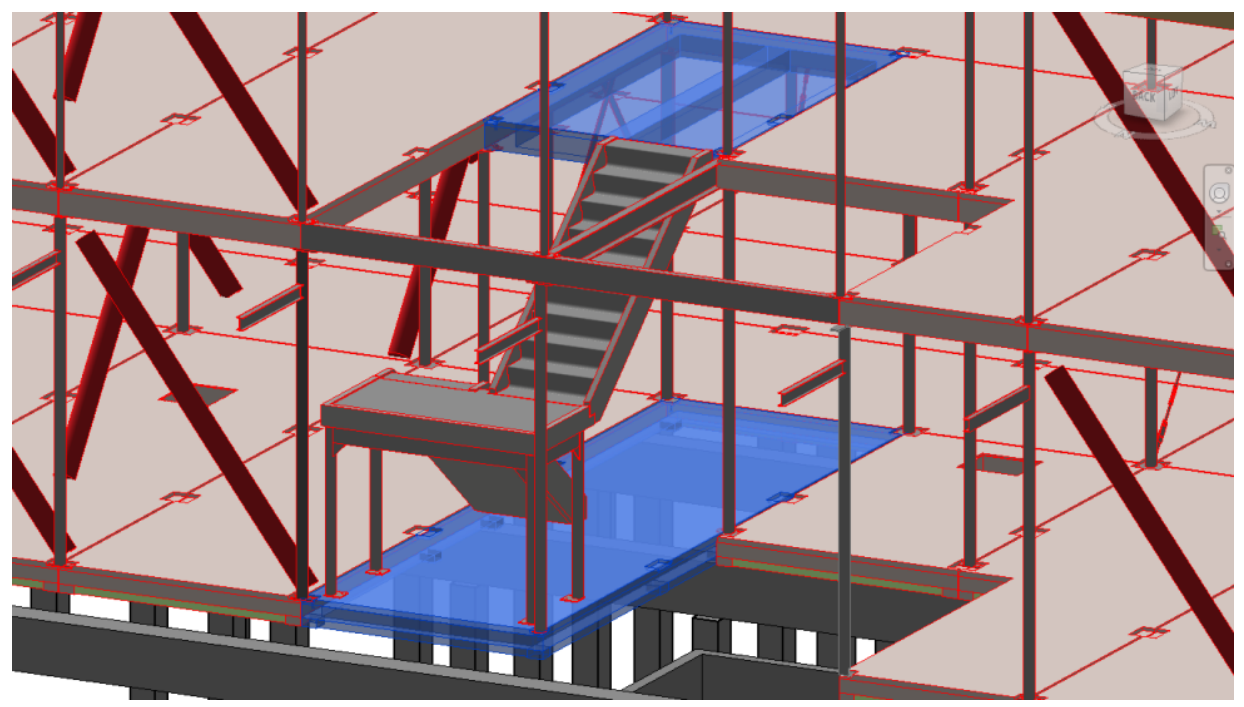

Figure 2: Screenshot of 3D model representing how a staircase is connected to two floors with different sizes

88 | BIM uses for deconstruction practices: Three ethnographic-action insights 
follows: "Then I can already check the 3D drawing to see what is practical. I can think about that [beforehand], instead of doing so when I am already there." Some other deconstruction workers found it "cool" to see a 3D model of the building they were demolishing, but others doubted its usefulness for the tasks they were assigned to. "We do not need to see a 3D model. We must just pick," explained one worker while picking cement edges from a disassembled floor. The use of 3D models nevertheless appeared to help interested workers, particularly site management, to analyze existing conditions of the building.

\section{BIM use II: reusable elements labeling}

Later ethnographic observations revealed that the intended reuse of façade elements implied they had to be labeled. "This type of projects is more strategic," said a deconstruction worker when the researcher observed how he cleaned up the ceiling. The planned reuse of almost the entire façade brought some extra complexities to the deconstruction project. The site supervisor had, for example, instructed the researcher and other new workers on the job to "perform softstripping carefully to prevent damage" to the modular façade elements. The demolition contractor also had to label these elements so that the system builder, subsequently, could plan and control where each element would be assembled in the new building. Designers and project leaders of the system

Table 10: Iterative improvement of "reusable elements labeling"

\begin{tabular}{|c|c|c|c|}
\hline Research stage & Iteration 1 & Iteration 2 & Iteration 3 \\
\hline $\begin{array}{l}\text { Ethnographic } \\
\text { observation }\end{array}$ & $\begin{array}{l}\text { All façade elements } \\
\text { need to be labeled } \\
\text { (numbered) on site }\end{array}$ & $\begin{array}{l}\text { Façade elements } \\
\text { have different } \\
\text { destinations }\end{array}$ & $\begin{array}{l}\text { Rainwater is pouring } \\
\text { into building: laptop } \\
\text { needs protection }\end{array}$ \\
\hline $\begin{array}{l}\text { Identification of work } \\
\text { routines }\end{array}$ & $\begin{array}{l}\text { 2D 'disassembly } \\
\text { drawing' is used with } \\
\text { exterior views }\end{array}$ & $\begin{array}{l}\text { Colors on (original) } \\
\text { 'disassembly drawing' } \\
\text { indicate destinations }\end{array}$ & $\begin{array}{l}\text { Procedure requires } \\
\text { multiple hands: } \\
\text { navigating and } \\
\text { labeling }\end{array}$ \\
\hline $\begin{array}{l}\text { Information system } \\
\text { development }\end{array}$ & $\begin{array}{l}\text { Codes from 2D } \\
\text { drawing are added to } \\
\text { the 3D (BIM) model } \\
\text { as 3D Model Texts }\end{array}$ & $\begin{array}{l}\text { Color of } 3 D \text { numbers } \\
\text { is updated in line } \\
\text { with drawings }\end{array}$ & $\begin{array}{l}\text { Laptop with virtual } \\
\text { environment is put } \\
\text { on crates on a } \\
\text { warehouse cart }\end{array}$ \\
\hline $\begin{array}{l}\text { Information system } \\
\text { implementation on } \\
\text { the project }\end{array}$ & $\begin{array}{l}\text { Demonstration of the } \\
\text { virtual environment } \\
\text { to foreman }\end{array}$ & $\begin{array}{l}\text { Trial on site with } \\
\text { laptop in the hand } \\
\text { deemed impractical }\end{array}$ & $\begin{array}{l}\text { Actual labeling of } \\
\text { façades with virtual } \\
\text { environment (easier } \\
\text { and better overview) }\end{array}$ \\
\hline
\end{tabular}


builder had earlier explained that they organized construction logistics in such a way that a site is supplied with building elements either directly from a to-bedeconstructed building or indirectly from a warehouse with previously deconstructed elements. In the focal project, (only) the façade elements had to be labeled on site according to a disassembly drawing that one of the system builder's designers had made.

An opportunity was identified to support this labeling project routine with a BIMbased method. The disassembly drawing displayed four exterior views of the building with hand-written codes above or below each façade element. The demolition contractor was asked to write those codes on some tape attached to the actual elements, i.e. to 'label' them. "However, we are always labeling the elements from the inside of the building," said the foreman when he discussed the routine with the researcher. The four-digit code on the far left of the drawing must then be written on the element on the far right. "We must [thus] think in mirror image," complemented the site supervisor. This could be confusing, particularly when also other building elements (like columns) need to be coded as well and one would "need to walk around with multiple drawings." During this discussion, the researcher proposed to integrate the required information with the previously developed 3D model. Though reluctant at first, both men decided to "give it a try."

A virtual environment was developed that presented the labeling information from a user's perspective. The researcher used a 3D Model Text feature of popular BIM software to add the codes from the four exterior disassembly views to the BIM model, initially using the demolition contractor's house style color. The model was exported and prepared for usage into a model viewer, the 'virtual environment.' When the foreman verified whether the model corresponded with the drawings, he asked whether it would be possible to use different colors for different codes in the model. The researcher then found out that, apart from the numbers, color coding is important to organize the logistical process: green façade elements were reserved for the construction of the school, blue ones would be stored at a warehouse of the system builder (until they could be used elsewhere) and the red ones were classified as waste. He consequently adapted the color of the 3D codes in the virtual environment. Developing this BIM-based method was nevertheless not limited to information modeling. That is, the researcher experienced that it would be impractical to simultaneously carry the laptop, navigate in the virtual environment and label the actual façade elements. In the hands-on spirit he had observed earlier among the (fellow) deconstruction workers - "there is a solution for everything" - he found a warehouse cart and a couple of crates that he used to create some sort of walkable desk. The 


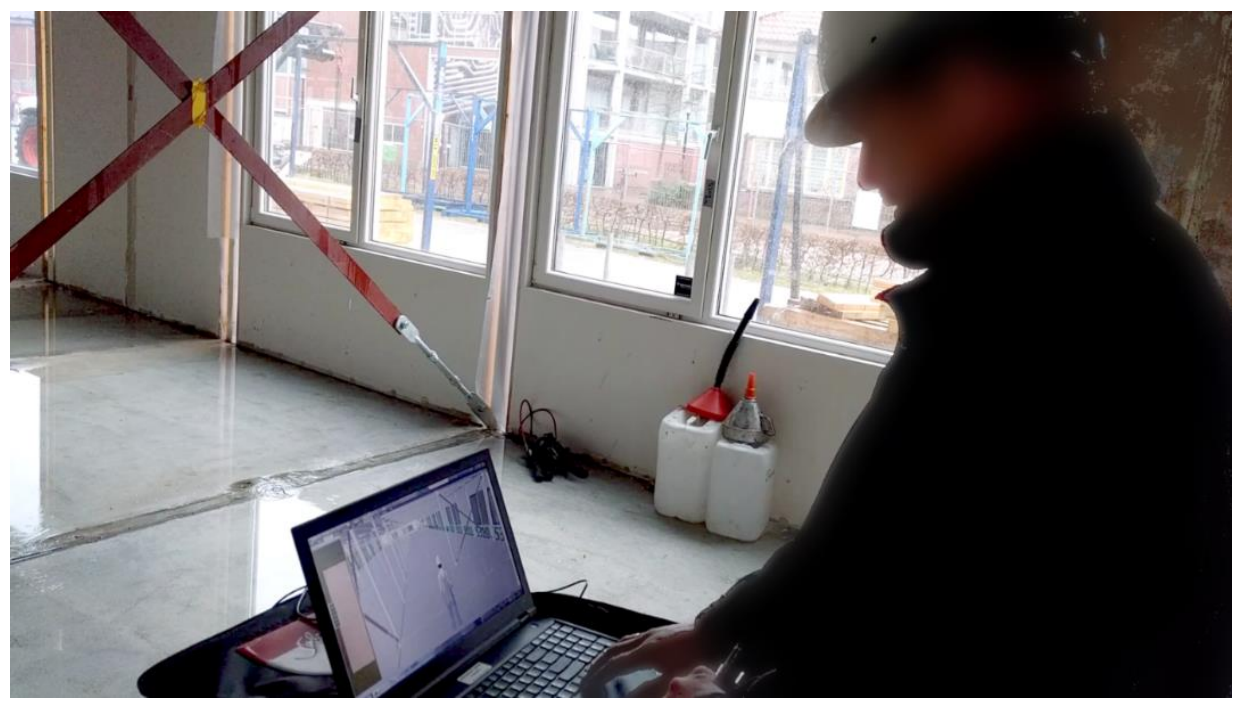

Figure 3: Overview of new routine - use of a virtual environment for labeling reusable elements

researcher put the laptop (with the virtual environment) on top of this and used a bag to protect it against the rainwater that was then pouring into the building.

This virtual environment replaced the disassembly drawing during the actual labeling of reusable elements. "Normally," the site supervisor said, "somebody holds the drawing, [another] walks around with a roll of tape and [a third person] writes down the numbers." This time, however, the site supervisor first attached some tape on each of the façade elements himself. Apparently not completely confident about how to use the system, he asked the researcher to control the avatar in the virtual environment while he would write the codes on the pieces of tape. Soon after they started labeling, the foreman came by to see how everything worked. "It is great," said the site supervisor and the foreman agreed. While joking about the places that the site supervisor could virtually visit, he tried to navigate in the virtual environment. Even though he accidentally pressed a button that reset the avatar's position, both men concluded it was very easy to use. The site supervisor then continued labeling all façade elements without the researcher's further help in navigating within the virtual environment (Figure 3). Afterwards, he reflected that this system helped him to get "a quick overview" of the building and that it worked "easier than a drawing." The different colors enabled him to see directly where the façade elements would need to be transported to. "I find it all quite nice. I had not expected this." He also requested the researcher to install the software at his own laptop and suggested that the system builder could just insert the codes into the model and send it to him. "I 
think that saves some time." The BIM-based method could be improved by adding two letters that indicate whether a façade has either a left-swinging or right-swinging window.

\section{BIM use III: $4 D$ deconstruction simulation}

Other ethnographic observations suggested that the project's deconstruction planning comprised the allocation of tasks to people and monitoring of their progress. This can be illustrated with an anecdote about the day two new deconstruction workers arrived at the site for the first time. The site supervisor welcomed them in the site office and informed them about safety regulations at the workplace. He then pointed to two large floor plans and explained how he kept track of the work's progress: "the pink parts are already finished." The ceiling still had to be cleaned up so that roof elements could be reused: this is what "the new guys" would be doing that day. "I will tell you how," said the site supervisor and he went ahead to the nursing home that was being deconstructed. "You can take this," he referred to rolling scaffolding once inside, "and use it to remove all those things on the ceiling." The introduction ended with instructions about separating different types of waste. When the deconstruction workers started

Table 11: Iterative improvement of "4D deconstruction simulation"

\begin{tabular}{|l|l|l|l}
\hline Research stage & Iteration 1 & Iteration 2 & Iteration 3 \\
\hline $\begin{array}{l}\text { Ethnographic } \\
\text { observation }\end{array}$ & $\begin{array}{l}\text { Site supervisor and } \\
\text { foreman allocate } \\
\text { demolition tasks on } \\
\text { site }\end{array}$ & $\begin{array}{l}\text { Sequence of lifting } \\
\text { façade elements is } \\
\text { determined by a } \\
\text { worker on the roof }\end{array}$ & $\begin{array}{l}\text { Perceived difference } \\
\text { between 'practice' } \\
\text { and 'theory' (office) } \\
\text { regarding planning }\end{array}$ \\
$\begin{array}{l}\text { Identification of work } \\
\text { routines }\end{array}$ & $\begin{array}{l}\text { Gantt chart and 2D } \\
\text { drawings attached to } \\
\text { the wall represent } \\
\text { plan }\end{array}$ & $\begin{array}{l}\text { Two workers on the } \\
\text { ground need to } \\
\text { detach loads and } \\
\text { group façade } \\
\text { elements }\end{array}$ & $\begin{array}{l}\text { Planning must be } \\
\text { abstract enough to } \\
\text { deal with fluctuations } \\
\text { in duration }\end{array}$ \\
\hline $\begin{array}{l}\text { Information system } \\
\text { development }\end{array}$ & $\begin{array}{l}\text { Façade elements } \\
\text { linked to distinct } \\
\text { disassembly activities } \\
\text { in a 4D simulation }\end{array}$ & $\begin{array}{l}\text { Color of façade } \\
\text { elements updated to } \\
\text { indicate destinations } \\
\text { (90\% transparent) }\end{array}$ & $\begin{array}{l}\text { 4D simulation links } \\
\text { product groups and } \\
\text { activities to align with } \\
\text { overall schedule }\end{array}$ \\
\hline $\begin{array}{l}\text { Information system } \\
\text { implementation on } \\
\text { the project }\end{array}$ & $\begin{array}{l}\text { Presentation of 4D } \\
\text { simulation (of façade) } \\
\text { during lunch break } \\
\text { with workers }\end{array}$ & $\begin{array}{l}\text { 4D simulation (of } \\
\text { façade) is shown to } \\
\text { and discussed with } \\
\text { site supervisor }\end{array}$ & $\begin{array}{l}\text { 4D simulation (of } \\
\text { entire project) is } \\
\text { shown to and } \\
\text { discussed with } \\
\text { foreman }\end{array}$ \\
\hline
\end{tabular}


with the task they were just assigned to, the site supervisor proceeded to check what other people were doing.

Allocating tasks and progress monitoring was later identified as an important project routine. The site supervisor was responsible for the overall deconstruction planning. He had pinned a graphical representation of this planning (Gantt chart) to one of the site office's walls - visible for everyone. The planning contained 23 tasks like "removing suspended ceiling", "demolishing internal walls first floor (cleaning up)" and "hoisting façade, timber frame, roofs and columns." The required number of people (1-6 workers) was written behind each of these tasks. Next to the schedule, several 2D drawings and floor plans were hanging on which the site supervisor marked parts that were completed. The information needed for planning the nursing home's deconstruction was thus dispersed over several documents. The site supervisor and/or the foreman preferred to allocate deconstruction tasks to the deconstruction workers at the site itself - "outside, in 3D!" - so they could just point to the specific building elements that had to be deconstructed and instruct how to do that.

To provide new opportunities for deconstruction planning, a 4D simulation was developed by linking schedule information to the BIM model. The model that the researcher created earlier contained foundations, floors, roofs, columns, wind braces, façades and some other elements - all modeled as distinct parametric objects. The researcher decided to connect this model to part of the schedule: hoisting of the façade elements. This was then one of the first upcoming tasks. Several deconstruction workers, including the foreman and site supervisor, estimated that the duration of that task would be two days. The researcher split the task in many sub-tasks (one for each façade element) to create a more detailed schedule. Based on the foreman's educated guess regarding the likely hoisting sequence, he linked all elements to a sub-task in order. This resulted in a $4 \mathrm{D}$ simulation that showed the sequenced deconstruction of the façade over time, which was revised after a lunchbreak presentation. The deconstruction workers first joked that they already "completed" the project when the simulation stopped and then, more serious, argued that they could not distinguish different destinations for the elements and that the hoisting sequence did not match reality. As for the latter, the foreman referred to one specific person as "the CEO of the roof. If [he] decides: we go left, then we will go to the left. And if he goes to the right, we will go in that direction." Considering these comments, the researcher first added colors indicating the different destinations for the materials and, after another trial, modeled more building parts (such as the suspended ceilings and internal walls) and linked the overall schedule to the product groups instead of individual elements. This resulted in a (simplified) 4D simulation for the entire project (Figure 4). 

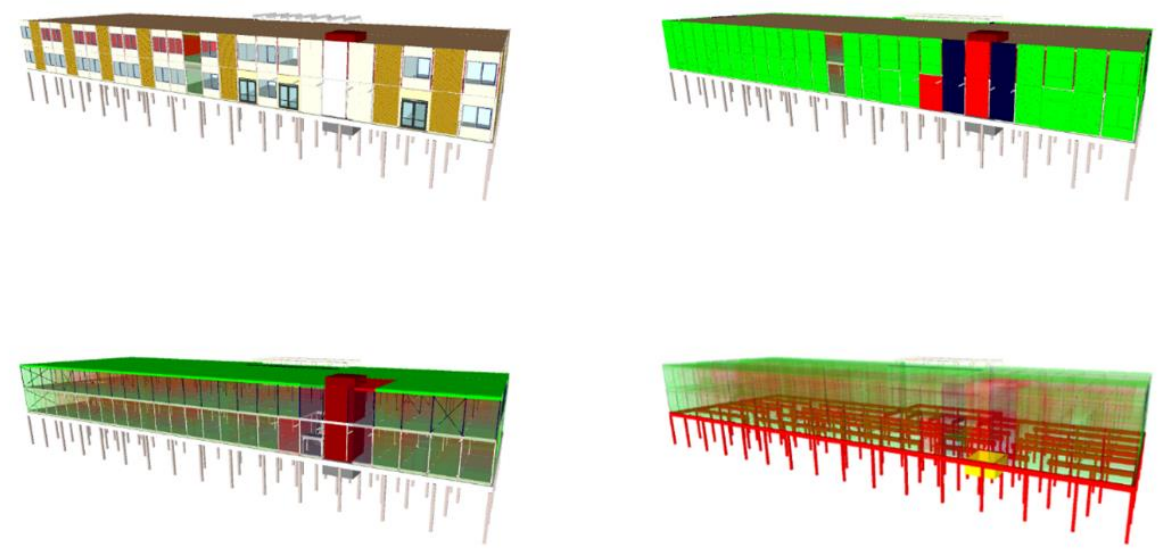

Figure 4: Snapshots of a 4D simulation that supports planning deconstruction activities

This BIM-based method was further field-tested near the end of the project. The researcher explained "theoretical" benefits of the 4D simulation during a few working sessions, like visualizing deconstruction sequences, progress monitoring or identifying space-time conflicts, but the deconstruction workers saw little practical value in it and no planning decisions were made with the method. The practitioners particularly criticized the rigidity of the information system, commenting that "it is not correct any longer if something is delayed" and that the (traditional) paper-based schedule on the wall could "be adapted easier." The site supervisor explained: "for planning purposes, it is perhaps nice to show how long it takes us [to disassemble something] ... but we [already] know that." There is no need to visualize or simulate the impact of potential delays either. "Sometimes, it can happen that a few façade elements are more difficult to disassemble because the screws ... do not want to get out. But the guys then automatically work a bit longer." Regarding allocating tasks to (new) deconstruction workers, for example those that do not speak the Dutch language, the site supervisor still speculated that it may "perhaps be nice for them to watch it." He and another senior deconstruction worker shared the view that "it is quite funny to watch how things are disassembled on the computer" but speculated that it would be "more interesting for the people working at the office [of the system builder], to see how things are going on site." The system builder's project leader later indeed showed great interest in the information system, but had little say in planning the deconstruction activities on site. 
Implementing the $4 \mathrm{D}$ simulation in the project hence provided few benefits for the deconstruction workers.

\section{Discussion}

This ethnographic-action research has explained how deconstruction activities could be supported with BIM-based methods. On one hand, we provided (ethnographic-oriented) insights about the local routines and the tacit knowledge that deconstruction workers possess and use to deal with these routines. On the other hand, we offered (action-oriented) insights about how three BIM-based methods could be developed and implemented for deconstruction activities on site. As our main contributions, we here reflect on the resulting three - heretofore unknown - BIM uses for deconstruction: 3D existing conditions analysis, reusable elements labeling and 4D deconstruction simulation. We also position these BIM uses in the wider literature and derive suggestions for future research.

\section{Contributions: three ethnographic-action insights for deconstruction}

Focused on site-based deconstruction activities, this study complements existing research with three ethnographic-action insights on how 3D models, a virtual environment and a 4D simulation can support, respectively, analyzing existing conditions, labeling reusable elements and planning deconstruction activities.

First, this study revealed that 3D models can support deconstruction workers in analyzing existing building conditions. To make sure that selected building elements can be reused after their disassembly, deconstruction workers need to adopt methods that cause minimal damage to those elements. Preexisting construction drawings were here routinely used on site to understand how the building was constructed. To contribute to that understanding, the first mentioned researcher developed a 3D model of the then existing building conditions through upgrading and integrating previously developed discipline models. Particular attention was paid to shapes, locations and connections of reusable building elements. The information system allowed the workers to view the building they were deconstructing from any angle. That appeared to be helpful in getting a global impression of the building, understanding construction details and determining deconstruction methods.

Second, this research demonstrated that virtual environments can support deconstruction workers in labeling reusable elements. Practitioners need information to efficiently plan and control the reuse of building elements after 
their disassembly. Deconstruction workers here established a routine to label façade elements on site using a 2D drawing provided by the system builder. The ethnographic-action researcher integrated the necessary information (four exterior views, numbers and color-coding) within a virtual environment that runs on a laptop. The BIM-based method helped the deconstruction workers through offering them the required information from their own perspective. The benefits included a quick overview of the building in 3D, no indoor mental translation (mirroring) of the exterior views, insight into the future destination of façade elements, easy virtual navigability and a fast workflow on site.

Third, this work showed that 4D simulations can limitedly support planning deconstruction activities. An overall project schedule and a set of 2D drawings on which the work's progress is monitored are the main artifacts practitioners used to this end. As the established project routine, deconstruction tasks were mainly allocated on the site by the site supervisor and/or foreman with reference to the (actual) building elements. The researcher created a 4D simulation by linking the drawings (combined in a BIM model) with the project schedule. This BIM-based method visualized and simulated the main deconstruction tasks over time. The 4D simulation gave the deconstruction workers an "interesting" overview of the planned deconstruction sequences and could inform new workers. However, little to no evidence was found that the method could support deconstruction workers with analyzing the impacts of delays, allocating tasks or monitoring progress.

\section{Implications and limitations of BIM uses}

These three ethnographic-action insights have several implications for research and practice. We have firstly drawn attention to the ways in which practitioners use information during deconstruction projects. While projects have previously been conceptualized as problems of organizing information (Winch, 2015), we substantiated that claim with empirical evidence for projects that deal with the deconstruction of buildings. Using in-depth data from a real-world project, we have argued that deconstruction workers use information for tasks like analyzing existing conditions, labeling reusable elements and planning deconstruction activities. Information, accordingly, appears to be an important contingency during deconstruction rather than merely before. As had been noted for sitebased construction practices (cf. Davies \& Harty, 2013), the information was mainly codified in drawings, schedules and other paper-based documents. Those artifacts were based on documents created during the design and construction phases; we empirically demonstrated that they can become relevant again during the end-of-life phase. From this, we recommend that researchers and 96 | BIM uses for deconstruction practices: Three ethnographic-action insights 
practitioners need to investigate how as-built BIM models (or other documentation) can be maintained, updated and passed on throughout a building's life-cycle efficiently so that a demolition contractor can - eventually take advantage from it as well.

We have secondly provided insights into the potentials of BIM-based methods for deconstruction activities, showing how deconstruction workers may benefit from methods that are adjusted to their needs: a 3D model, virtual environment and 4D simulation. This directly addresses the scarce implementation of BIM for existing buildings, a core finding by Volk et al. (2014). Previous studies that discussed particular benefits of BIM-based information systems also focused mostly on design and/or construction phases (cf. Bryde et al., 2013). We observed here similar benefits during the end-of-life phase, although we can ascribe fewer benefits to 4D simulations than, for example, Olde Scholtenhuis et al. (2016) particularly because coordination between different trades/sub-contractors seemed less important for planning deconstruction. We nevertheless illustrated that BIM-based methods can (partly) replace paper-based methods for some deconstruction activities and that practitioners reflected predominantly positively on those changes. This work thereby demonstrates that deconstruction workers can reap the benefits of BIM-based methods when those are customized to their local working routines.

In doing so, this study is - to the best of our knowledge - the first to apply an ethnographic-action research methodology to study deconstruction practices on site. Reflecting on the use of this methodology, we argue that the iterative improvement of information systems (here: BIM-based methods) together with industry practitioners may benefit from two extra steps. First, 'preparatory explorations' through conducting preliminary interviews or participating in (physical) labor can help to establish trust and provide the first clues for relevant project routines to observe. Since some relevant routines may only take place at selected points in time during a project (like labeling of the façade here), it is important to identify them early on; having established trust is necessary to secure the practitioners' collaboration. Second, 'collaborative learning' through systematically reflecting on the information systems together with practitioners can help in drawing lessons with scientific and practical relevance. A formal closure of the collaborative research process, for example with a workshop (like here), allows researchers to verify any preliminary results and practitioners to ask advice on scaling up successful information systems. The iterative ethnographicaction loop as proposed by Hartmann et al. (2009) may thus be extended by adding a 'preparatory explorations' step at the start and a 'collaborative learning' step at the end of the study. 
More research is needed to strengthen this study's findings and its generalizability though. The implementation of BIM-based methods here was emergent and exploratory, which is in line with the ethnographic-action research methodology, but formal generalization is therefore limited to "the force of example" (Flyvbjerg, 2006, p. 228). Literal replications and quantitative approaches to "measure" the benefits of the proposed methods are necessary next steps to formulate cause-and-effect relationships. Although Pink et al. (2010) advocated shorter "innovative" approaches to doing ethnography to accommodate project timescales and industry limitations, "classic" approaches typically also recommend longer periods of fieldwork. Since the project was finished and the building gone, the latter was not possible here. More fieldwork in other deconstruction projects could, however, result in the identification of additional project routines that could be supported with BIM-based methods. A promising direction for future research concerns, for example, site layout planning systems that account for specific deconstruction routines.

\section{Conclusions}

BIM-based methods can support deconstruction practices on site. Substantiated with empirical evidence from a 'best practice' deconstruction project, this study complements previous studies that only touched upon how deconstruction workers use information on site and ignored how they could thereby benefit from BIM. Ethnographic methods here revealed that deconstruction workers need information to (I) analyze existing conditions, (II) label reusable building elements and (III) plan deconstruction activities. Action-oriented methods subsequently provided insights into (I) how a 3D model can inform about building details and deconstruction methods in the first routine, (II) how a virtual environment can beneficially present the necessary labeling information from a user's perspective in the second routine and (III) how a 4D simulation could inform about the planned deconstruction sequence in the third routine. Taken together, these ethnographic-action insights hence revealed three new BIM uses for a building's deconstruction phase: '3D existing conditions analysis', 'reusable elements labeling' and ' $4 \mathrm{D}$ deconstruction simulation'. Through leveraging the potentials of BIM, this study thereby opens up new possibilities to support deconstruction and the reuse of building elements.

98 | BIM uses for deconstruction practices: Three ethnographic-action insights 


\section{References}

Adriaanse, A. M., Voordijk, J. T., \& Dewulf, G. P. M. R. (2010). Adoption and use of interorganizational ICT in a construction project. Journal of Construction Engineering and Management, 136(9), 1003-1014.

Akanbi, L. A., Oyedele, L. O., Akinade, O. O., Ajayi, A. O., Davila Delgado, M., Bilal, M., \& Bello, S. A. (2018). Salvaging building materials in a circular economy: A BIMbased whole-life performance estimator. Resources, Conservation and Recycling, 129, 175-186.

Akbarnezhad, A., Ong, K. C. G., \& Chandra, L. R. (2014). Economic and environmental assessment of deconstruction strategies using Building Information Modeling. Automation in Construction, 37, 131-144.

Akinade, O. O., Oyedele, L. O., Bilal, M., Ajayi, S. O., Owolabi, H. A., Alaka, H. A., \& Bello, S. A. (2015). Waste minimisation through deconstruction: A BIM based Deconstructability Assessment Score (BIM-DAS). Resources, Conservation and Recycling, 105, 167-176.

Akinade, O. O., Oyedele, L. O., Omoteso, K., Ajayi, S. O., Bilal, M., Owolabi, H. A., ... Henry Looney, J. (2017). BIM-based deconstruction tool: Towards essential functionalities. International Journal of Sustainable Built Environment, 6(1), 260 271.

Allwood, J. M., Ashby, M. F., Gutowski, T. G., \& Worrell, E. (2011). Material efficiency: A white paper. Resources, Conservation and Recycling, 55(3), 362-381.

Alsafouri, S., \& Ayer, S. K. (2018). Review of ICT implementations for facilitating information flow between virtual models and construction project sites. Automation in Construction, 86, 176-189.

Azhar, S. (2011). Building Information Modeling (BIM): Trends, Benefits, Risks, and Challenges for the AEC Industry. Leadership and Management in Engineering, 11(3), 241-252.

Azhar, S., Ahmad, I., \& Sein, M. K. (2009). Action research as a proactive research method for construction engineering and management. Journal of Construction Engineering and Management, 136(1), 87-98.

Brand, S. (1994). How buildings learn: What happens after they're built. New York: Penguin.

Bryde, D., Broquetas, M., \& Volm, J. M. (2013). The project benefits of Building Information Modelling (BIM). International Journal of Project Management, 31(7), 971-980.

Cheng, J. C. P., \& Ma, L. Y. H. (2013). A BIM-based system for demolition and renovation waste estimation and planning. Waste Management, 33(6), 1539-1551.

Cheshire, D. (2016). Building Revolutions: applying the circular economy to the built environment. Newcastle upon Tyne: RIBA Publishing.

Chini, A. R., \& Bruening, S. F. (2003). Deconstruction and materials reuse in the United States. Retrieved from

Coelho, A., \& De Brito, J. (2011). Economic analysis of conventional versus selective demolition-A case study. Resources, Conservation and Recycling, 55(3), 382392.

Coelho, A., \& De Brito, J. (2013). Conventional demolition versus deconstruction techniques in managing construction and demolition waste (CDW) Handbook of Recycled Concrete and Demolition Waste (pp. 141-185): Woodhead Publishing.

References $\mid 99$ 
Cooper, D. R., \& Gutowski, T. G. (2015). The environmental impacts of reuse: a review. Journal of Industrial Ecology.

Dantata, N., Touran, A., \& Wang, J. (2005). An analysis of cost and duration for deconstruction and demolition of residential buildings in Massachusetts. Resources, Conservation and Recycling, 44(1), 1-15.

Davies, R., \& Harty, C. (2013). Implementing 'Site BIM': A case study of ICT innovation on a large hospital project. Automation in Construction, 30, 15-24.

Diyamandoglu, V., \& Fortuna, L. M. (2015). Deconstruction of wood-framed houses: Material recovery and environmental impact. Resources, Conservation and Recycling, 100, 21-30.

Eastman, C., Teicholz, P., Sacks, R., \& Liston, K. (2011). BIM Handbook: a guide to Building Information Modeling. Hoboken: John Wiley \& Sons.

Flyvbjerg, B. (2006). Five misunderstandings about case-study research. Qualitative Inquiry, 12(2), 219-245.

Gálvez-Martos, J. L., Styles, D., Schoenberger, H., \& Zeschmar-Lahl, B. (2018). Construction and demolition waste best management practice in Europe. Resources, Conservation and Recycling, 136, 166-178.

Ge, X. J., Livesey, P., Wang, J., Huang, S. H., He, X., \& Zhang, C. (2017). Deconstruction waste management through $3 \mathrm{~d}$ reconstruction and bim: a case study. Visualization in Engineering, 5(1), 13.

Gorgolewski, M. (2008). Designing with reused building components: some challenges. Building Research \& Information, 36(2), 175-188.

Grosse, H. (2018). An insider's point of view: autoethnography in the construction industry. Construction Management and Economics, 1-18.

$\mathrm{Gu}$, N., \& London, K. (2010). Understanding and facilitating BIM adoption in the AEC industry. Automation in Construction, 19(8), 988-999.

Hartmann, T., Fischer, M., \& Haymaker, J. (2009). Implementing information systems with project teams using ethnographic-action research. Advanced Engineering Informatics, 23(1), 57-67.

Hartmann, T., Gao, J., \& Fischer, M. (2008). Areas of application for 3D and 4D models on construction projects. Journal of Construction Engineering and Management, 134(10), 776-785.

Hartmann, T., Van Meerveld, H., Vossebeld, N., \& Adriaanse, A. (2012). Aligning Building Information Model tools and construction management methods. Automation in Construction, 22, 605-613.

Hosseini, M. R., Rameezdeen, R., Chileshe, N., \& Lehmann, S. (2015). Reverse logistics in the construction industry. Waste Management \& Research, 33(6), 499-514.

Iacovidou, E., \& Purnell, P. (2016). Mining the physical infrastructure: Opportunities, barriers and interventions in promoting structural components reuse. Science of the Total Environment, 557, 791-807.

Kibert, C. J. (2016). Sustainable construction: green building design and delivery. John Wiley \& Sons.

Kourmpanis, B., Papadopoulos, A., Moustakas, K., Stylianou, M., Haralambous, K. J., \& Loizidou, M. (2008). Preliminary study for the management of construction and demolition waste. Waste Management \& Research, 26(3), 267-275. 
Koutamanis, A., Van Reijn, B., \& Van Bueren, E. (2018). Urban mining and buildings: A review of possibilities and limitations. Resources, Conservation and Recycling, 138, 32-39.

Kreider, R. G., \& Messner, J. I. (2013). The Uses of BIM: Classifying and selecting BIM Uses. Retrieved from University Park, PA, USA: http://bim.psu.edu

Lansink, A. (2017). Challenging changes: Connecting waste hierarchy and circular economy. Nijmegen: DPN Rikken.

Löwstedt, M. (2015). 'Taking off my glasses in order to see': exploring practice on a building site using self-reflexive ethnography. Construction Management and Economics, 33(5-6), 404-414.

Olde Scholtenhuis, L. L., Hartmann, T., \& Dorée, A. G. (2016). Testing the value of 4D visualizations for enhancing mindfulness in utility reconstruction works. Journal of Construction Engineering and Management, 142(7), 04016015.

Phelps, A. F., \& Horman, M. J. (2009). Ethnographic theory-building research in construction. Journal of Construction Engineering and Management, 136(1), 5865.

Pink, S., Tutt, D., Dainty, A., \& Gibb, A. (2010). Ethnographic methodologies for construction research: knowing, practice and interventions. Building Research \& Information, 38(6), 647-659.

Pomponi, F., \& Moncaster, A. (2017). Circular economy for the built environment: A research framework. Journal of Cleaner Production, 143, 710-718.

Poon, C. S., Yu, A. T. W., See, S. C., \& Cheung, E. (2004). Minimizing demolition wastes in Hong Kong public housing projects. Construction Management and Economics, 22(8), 799-805.

Pun, S. K., Liu, C., \& Langston, C. (2006). Case study of demolition costs of residential buildings. Construction Management and Economics, 24(9), 967-976.

Sacks, R., Koskela, L., Dave, B. A., \& Owen, R. (2010). Interaction of Lean and Building Information Modeling in Construction. Journal of Construction Engineering and Management, 136(9), 968-980.

Schultmann, F., \& Sunke, N. (2007). Energy-oriented deconstruction and recovery planning. Building Research \& Information, 35(6), 602-615.

Sebastian, R., \& Van Berlo, L. (2010). Tool for benchmarking BIM performance of design, engineering and construction firms in the Netherlands. Architectural Engineering and Design Management, 6(4), 254-263.

Shen, W., Zhang, X., Shen, G. Q., \& Fernando, T. (2013). The user pre-occupancy evaluation method in designer-client communication in early design stage: A case study. Automation in Construction, 32, 112-124.

Siebelink, S., Voordijk, J. T., \& Adriaanse, A. (2018). Developing and testing a tool to evaluate BIM maturity: Sectoral analysis in the Dutch construction industry. Journal of Construction Engineering and Management, 144(8), 05018007.

Spradley, J. P. (1979). The ethnographic interview. New York: Holt, Rinehart and Winston. Spradley, J. P. (1980). Participant observation. New York: Holt, Rinehart and Wineston.

Succar, B. (2009). Building information modelling framework: A research and delivery foundation for industry stakeholders. Automation in Construction, 18(3), 357375. 
Van den Berg, M., Hartmann, T., \& De Graaf, R. (2017). Supporting design reviews with pre-meeting virtual reality environments. Journal of Information Technology in Construction, 22(16), 305-321.

Volk, R., Stengel, J., \& Schultmann, F. (2014). Building Information Modeling (BIM) for existing buildings - Literature review and future needs. Automation in Construction, 38, 109-127.

Winch, G. M. (2015). Project organizing as a problem in information. Construction Management and Economics, 33(2), 106-116.

Won, J., \& Cheng, J. C. P. (2017). Identifying potential opportunities of Building Information Modeling for construction and demolition waste management and minimization. Automation in Construction, 79, 3-18.

Wong, J. K. W., \& Zhou, J. (2015). Enhancing environmental sustainability over building life cycles through green BIM: A review. Automation in Construction, 57, 156-165. 


\section{Chapter 4}

BIM uses for reversible building design: Identification, classification \& elaboration

Marc van den Berg \& Elma Durmisevic

Published

Van den Berg, M., \& Durmisevic, E. (2017). BIM uses for reversible building design: Identification, elaboration \& classification. Paper presented at the $3^{\text {rd }}$ Green Design Conference, Mostar, Bosnia-Herzegovina. 


\section{Abstract}

The construction industry urgently needs new approaches to design buildings that can be incorporated in the circular economy. Buildings are still predominantly conceived as static structures with one end-of-life option, demolition, which typically results in excessive amounts of waste. To cut waste, buildings need to be designed as reversible structures that enable transformations, disassembly and reuse of building elements. This may be complex in practice due to the significant information processing capabilities it requires, but previous research has suggested that Building Information Modeling (BIM) could be valuable in the additional gathering, interpreting and synthesizing of information needed. This paper aims to explore how BIM can support reversible building design through an in-depth case study of the reversible building design practices of a Dutch system builder. Eight BIM uses were systematically identified, classified and elaborated on according to the extent they can support reversible building design. It is concluded that three 'key' BIM uses can fully support reversible building design (design authoring, 3D coordination and drawing production), two 'viable' BIM uses partially (quantity take-off and design review) and three 'negligible' BIM uses deficiently (phase planning, code validation and engineering analyses). The insights and recommendations derived from this paper hopefully assist in selecting BIM uses to design and study tomorrow's reversible buildings.

Keywords: Building Information Modeling; BIM use, Case study; Reversible building 


\section{Introduction}

The construction industry urgently needs new approaches to design buildings that can be incorporated in the circular economy. Buildings are still predominantly conceived as static structures with one end-of-life option: demolition. On one hand, this typically results in excessive amounts of waste being generated (Cha et al., 2011). Construction and demolition (C\&D) waste contributes about $40 \%$ of all solid waste in developed countries (Cheshire, 2016; Wong \& Zhou, 2015), with the largest part of C\&D waste over the life-cycle of a building being generated during demolition (Schultmann \& Sunke, 2007). On the other hand, buildings consume large volumes of virgin resources, which are extracted with considerable environmental damage, in this linear economic system (Gorgolewski, 2008; Huuhka \& Lahdensivu, 2016). Moreover, the demand for those resources is likely to increase substantially due to ever-expanding economies and populations (Allwood et al., 2011). This increasingly critical socioenvironmental problem is forcing the construction industry to adopt design guidelines for reversible (rather than static) buildings.

A reversible building is a type of building that is specifically designed to enable transformations, disassembly and reuse of building elements. Transformations involve the change from one building form into another through eliminating, adding, relocating or substituting parts. They are the result of the need to adjust physical surroundings to human activities and may occur on the spatial, structural or material level of a building (Durmisevic, 2006, p. 84). Disassembly is the careful dismantling of a building structure to maximize the recovery of its elements for reuse. Reuse is the process during which discarded building elements are recirculated (and sometimes upgraded according to the material structure) and used for the same function without destruction (Iacovidou \& Purnell, 2016). This preserves the invested embodied energy of deconstructed building parts, extends their service life and significantly reduces the cost, energy use and carbon emissions resulting from demolition, processing for recycling and transportation to landfill and recycling facilities (Akbarnezhad et al., 2014). Through enabling transformations and reuse, the theoretical goal of reversible building design is to design-out waste. In other words, it aims to close the loop of material usage and to achieve upgrading rather than downgrading/downcycling of building materials. That is not easy to achieve in practice though due to the significant information processing capabilities it requires (Van den Berg, Voordijk, \& Adriaanse, 2017).

Building Information Modeling (BIM) has the potential to support the gathering, interpreting and synthesizing of information needed to design reversible buildings. BIM has frequently been defined as a set of interacting policies, 
processes and technologies generating a methodology to manage the essential building design and project data in digital format throughout the building's lifecycle (Succar, 2009; Succar, Sher, \& Williams, 2012). It is centered around the deployment of a digital representation of a building, the building information model (also abbreviated with BIM). A wide range of methods of applying that model (with one or more specific objectives) have been developed over the years, including quantity take-off (cost estimation), phase planning (4D simulation) and $3 \mathrm{D}$ coordination (clash detection). However, little is known about how such BIM uses may assist in dealing with the additional complexities of designing reversible buildings described in earlier studies (Gorgolewski, 2008).

This paper therefore explores how BIM can support reversible building design. The upcoming section identifies possible BIM uses and describes their potential benefits. The section thereafter discusses the case study method that was used to investigate which uses were implemented and how. The paper then continues with presenting and discussing the findings and concludes with a classification and elaboration on how BIM can be leveraged for reversible building design.

\section{Theoretical framework}

Building Information Modeling is the result of a long series of computerintegrated construction research for interactive 3D design since the 1970s. Turk (2016) argues that designers have always used information models to describe buildings, but that those models became digital with the adoption of information technology and that they have since then become increasingly well structured. Computer-aided design (CAD) evolved from $2 \mathrm{D}$ geometry via 3D geometry towards $3 \mathrm{D}$ parametric objects. Where in a geometric CAD system, the human needs to interpret, for example, a cylinder as a structural column, in BIM software this is explicitly stated in the resulting database. Specialized engineering software has been based on engineering objects rather than geometry. Current BIM software represents building parts as objects that carry computable graphic and data attributes that identify them to software applications, as well as parametric rules that allow them to be manipulated in an intelligent fashion (Eastman et al., 2011, p. 16).

In that way, BIM enables the creation, development and use of semantically rich information models. Ongoing research and software development has led to a wide variety of BIM tools and technologies. The potential uses of those tools and technologies have been documented extensively (Barlish \& Sullivan, 2012; Bryde et al., 2013; Moum, 2010). In an attempt to classify those uses, a BIM use was defined as "a method of applying Building Information Modeling during a facility's lifecycle to achieve one or more specific objectives" (Computer 106 | BIM uses for reversible building design: Identification, classification \& elaboration 
Integrated Construction Research Program, 2010). Other categorizations of BIM uses (or "functionalities") are found in the studies of Won and Cheng (2017), Sacks, Koskela, et al. (2010) and Eastman et al. (2011). Here, based on these sources, eight BIM uses that can contribute to the (reversible) design process are identified and discussed.

- Design authoring: a process in which a BIM model is developed based on previously established criteria. BIM authoring tools can make designing more productive through eliminating rework, providing consistency between different views of the same model and powerful design visualizations (Eastman et al., 2011).

- Quantity take-off (cost estimation): a process that can produce a list of quantity information of materials and building elements from a BIM model. This makes it possible to quickly generate a bill of quantities and to make cost estimates (Azhar, 2011). Precisely and accurately quantifying modeled materials can be particularly useful to measure the effects of additions and modifications to the model.

- Phase planning (4D simulation): a process in which an information model is integrated with a project schedule to visualize phased occupancy, construction sequences and space requirements on a construction site. 4D modeling can support the coordination of various construction activities (Hartmann \& Fischer, 2007; Trebbe, Hartmann, \& Dorée, 2015).

- 3D coordination (clash detection): a process to identify field conflicts by comparing 3D models of building systems and to eliminate the conflicts prior to installation. This may lead to cost savings of up to $10 \%$ of the contract value (Azhar, 2011).

- Design review: a process in which a design solution is evaluated by relevant stakeholders to detect any possible failures with respect to program, function of spaces or overall performance (Castronovo, Nikolic, Liu, \& Messner, 2013; Shiratuddin \& Thabet, 2007, 2011). The feedback may help in resolving design and constructability issues.

- Code validation: a process in which code validation software is utilized to check the parameters of a BIM model against project specific codes (Computer Integrated Construction Research Program, 2010; Eastman et al., 2011). This reduces the chance of code design errors and automation has the potential to save time on multiple checking for code compliance.

- Drawing production: a process in which drawings and drawings sets are automatically generated from a BIM model. This includes Schematic Design, Design Development, Construction and Shop Drawings (Eastman et al., 2011). The same model can be used to create all drawings, reports and analysis datasets, thereby eliminating the need to manually update each drawing for each design change. 
- Engineering analyses (structural, lighting, energy, mechanical, other): a process in which the BIM model is used to determine the most effective engineering method based on design specifications. BIM provides several advantages over traditional $2 \mathrm{D}$ or $3 \mathrm{D}$ models due to the richness of object information necessary for analyses. BIM analysis tools have been developed for structural, lighting, energy, mechanical and other engineering analyses (Eastman et al., 2011; Jalaei \& Jrade, 2014).

Other well-documented BIM uses, such as Record modeling, Asset management and Supply chain management, deal more with project phases other than the design phase - while the latter is the focus here. Designing reversible buildings explicitly considers the configuration of building elements, their functions and relationships in a way that satisfies requirements and constraints for disassembly, reuse and transformation. Durmisevic (2006) has suggested that this can be achieved by systematically considering independence and exchangeability of building systems/components in three design domains: the functional (material levels), technical (hierarchy) and physical (interfaces) domain. As such, reversible building design can be seen as an activity concerned with different relationships and interdependencies. Previous works have studied above BIM uses for (traditional, static) building design, but implementations for reversible building design have not been documented well.

\section{Research methodology}

The aim of this research is to explore how BIM can support reversible building design through identifying, classifying and elaborating on BIM use implementations. A case study was chosen as method as it enables to gain indepth insights about real-world events (Eisenhardt, 1989). This type of research is particularly useful to answer how/why questions about a contemporary set of events over which the researchers have little or no control (Yin, 2009) - like here. The unit of analysis in this case study is the design practice of a Dutch system builder. This company successfully designs, constructs (and, together with a partnering firm, often disassembles) buildings with mostly temporary or semipermanent functions. For the main structure, the firm therefore uses modular, prefabricated building elements that match with each other, such as foundation, column, façade and roof elements with standardized sizes. The use life-cycle of most of the firm's buildings is relatively short, so a unique yet key design consideration is that these can be disassembled easily and that the aforementioned elements can be reused elsewhere. For the context of this study, their designs are therefore seen as 'reversible.' 
Data about BIM uses in reversible building design practice is collected from multiple sources as to enable data triangulation. The most important data source concerns two rounds of semi-structured interviews with knowledgeable practitioners from the focal company, such as a designer, project leader and expedition/logistics manager. The first round of interviews dealt with information management practices within the firm. This round was followed by a second round in which an in-depth interview was held with one of the designers. Questions included if and how the eight BIM uses (derived from literature) were implemented in the firm's design practices. The first mentioned author conducted and recorded all (seven) interviews and transcribed them verbatim. A summary of the transcriptions was then sent to the interviewees for verification purposes. Other data that was collected includes a BIM model, 2D and 3D drawings, schedules, cost estimations, e-mail correspondence and contract documents.

Data analysis involved systematically examining, categorizing and comparing the collected data. The aforementioned BIM uses were identified a priori and guided the analysis - which is the "most preferred strategy" in case study research (Yin, 2009 , p. 130). The transcriptions were examined for BIM uses within the context of reversible building design. Relevant excerpts were marked and later categorized in a table with BIM uses. All other evidence was assessed and the interpretations were recombined with this table, thereby considering alternative interpretations of the theoretical relations that were emerging. It was then also decided to further specify the findings of the BIM use 'design authoring' in a distinct appendix, since this use turned out to be the most dominant of all uses (but those specifics were not the main focus here). Hence, comparing the evidence from practice with the identified BIM uses made it possible to classify and elaborate on each of the eight theoretical BIM uses for reversible building design.

\section{Results}

The case study's focal firm has implemented some, but not all, BIM uses in their reversible building design processes. BIM is mainly comprehended as a way to draw in three dimensions, rather than as a way to organize relevant project information in a database. Design authoring, the BIM use that is concerned with the creation of the actual model of a building, is seen as the most important use (and specified in more detail in Table 12).

- Design authoring: In their project work, the focal firm's designers use BIM to efficiently create representations of buildings. All standardized, prefabricated 
Table 12: Implementation of reversible building design guidelines with BIM in case study

\begin{tabular}{|c|c|}
\hline $\begin{array}{l}\text { Reversible building } \\
\text { design guideline }^{1}\end{array}$ & Implementation with BIM \\
\hline $\begin{array}{l}\text { 1. Functional } \\
\text { decomposition }\end{array}$ & $\begin{array}{l}\text { Different design disciplines (e.g. structural, MEP) add data to one main } \\
\text { (i.e. architectural) model. A distinction is made between structural and } \\
\text { non-structural elements. No conscious functional separation for other } \\
\text { elements. }\end{array}$ \\
\hline $\begin{array}{l}\text { 2. Systematization } \\
\text { and clustering }\end{array}$ & $\begin{array}{l}\text { Buildings are systematized to a great extent: they are all made of } \\
\text { modular, prefabricated elements from the following categories: } \\
\text { foundation, floor, column, wall, façade and roof elements. All of these } \\
\text { are available as parametric object families within the BIM software used. }\end{array}$ \\
\hline $\begin{array}{l}\text { 3. Hierarchical } \\
\text { relations between } \\
\text { elements }\end{array}$ & $\begin{array}{l}\text { The most important hierarchical distinction between building elements } \\
\text { is whether an element has a structural function (or not). Parametric } \\
\text { objects therefore have a parameter that indicates this. Similarly, walls } \\
\text { can be room bounding (or not), which is also indicated with a parameter } \\
\text { which value can be changed. }\end{array}$ \\
\hline $\begin{array}{l}\text { 4. Base element } \\
\text { specification }\end{array}$ & $\begin{array}{l}\text { Snap points are used within the BIM software to define how building } \\
\text { elements are connected with each other. These snap points are linked to } \\
\text { the regular building grid. Some parametric families have their own snap } \\
\text { points (e.g. piping needs to be connected to the sanitary system). No } \\
\text { conscious specification of base elements. }\end{array}$ \\
\hline $\begin{array}{l}\text { 5. Assembly } \\
\text { sequences }\end{array}$ & $\begin{array}{l}\text { The BIM software enables the creation of an exploded view of the } \\
\text { building design, which can be used to communicate assembly } \\
\text { sequences. An exploded view is typically accompanied with some } \\
\text { (manually inserted) texts. No design optimizations regarding } \\
\text { (dis)assembly sequences. }\end{array}$ \\
\hline $\begin{array}{l}\text { 6. Interface } \\
\text { geometry }\end{array}$ & $\begin{array}{l}\text { The geometry of interfaces is standardized to a large extent. This is a } \\
\text { core part of the building system applied in all projects. It is represented } \\
\text { in a simplified way in the BIM model. At the highest level of detail, the } \\
\text { location of bolts is modeled (yet manufacturing information is missing). }\end{array}$ \\
\hline $\begin{array}{l}\text { 7. Type of } \\
\text { connections }\end{array}$ & $\begin{array}{l}\text { Connections between elements are mostly mechanical (rather than } \\
\text { chemical), being bolts and screws. That knowledge is primarily implicit } \\
\text { and modeled limitedly to make sure the model becomes not too heavy } \\
\text { (in terms of processing power). }\end{array}$ \\
\hline $\begin{array}{l}\text { 8. Life-cycle } \\
\text { coordination }\end{array}$ & $\begin{array}{l}\text { Data about the expected life-cycle duration is not linked to the model. } \\
\text { Information about warrantees is shared with a client through other } \\
\text { project documentation (such as contracts). Within the BIM software, a } \\
\text { phasing functionality is used to define whether building elements are } \\
\text { new or reused. }\end{array}$ \\
\hline
\end{tabular}

${ }^{1}$ Guidelines are based on the design for disassembly aspects of Durmisevic (2006, p. 161)

building elements that the firm uses to (re)construct a building are available as object families in the BIM software platform used. Instances of these objects 
can be inserted in a project template and set to different levels of detail (ranging from coarse to fine), corresponding with the relevant design stage. The parametric object behavior reduces repetitive design work (and rework), since modifications to one object in one view automatically propagate to other objects and views. Product data, like available materials for façade elements, is received from sub-contractors or, mainly, suppliers and is stored in an extensive library. Rendering, the process of creating 2D images with 3D (photo)realistic effects, is not always yielding satisfying results and is therefore sometimes outsourced.

- Quantity take-off (cost estimation): Cost estimations are based on the BIM model. The parametric objects in the model contain data that makes it possible to identify and count them. Designers can use that to generate a bill of quantities (take-off), which serves as a basis for cost estimations (but not for work preparation). These cost estimations are complemented by (or replaced with) manual calculations, since the cost estimators typically find that less time-consuming and also expect the latter to be more accurate.

- Phase planning (4D simulation): No 4D simulations are conducted to inform the building design. The planning of a construction project is graphically represented with Gantt charts in which the activities are represented as horizontal bars that have certain relations with each other. Such schedules are not integrated or linked with a BIM model, even though the firm has the necessary software licenses. Planning the construction works is seen as a task for the project leaders (who also do not deploy 4D simulations) rather than an activity to inform or optimize a building's design.

- 3D coordination (clash detection): The firm performs clash detections to identify and resolve design issues. Different aspect models, representing design work from different design disciplines, subcontractors or suppliers, are therefore compared with each other in specific software. The firm pursues an 'open BIM' policy, requesting the IFC file format for importing and exchanging data models. Spatial conflicts that are being detected by the software are visually evaluated by a designer, who then makes screenshots and annotations about those conflicts that need to be resolved. Subsequently, potential solutions are discussed between the different designers in order to decide what solution is most preferable.

- Design review: BIM is used to evaluate a design proposal with a client and to receive feedback. This is typically done by designers who make cross-sections, floor plans and 3D images from the BIM model to show relevant design details; the 3D model itself is only sometimes shared with a client. During a review, it is discussed whether the designed solution complies with the intent of the client. Such review meetings are primarily conducted by a project leader rather than a designer. Project leaders do not use walkthroughs or other functionalities from 3D viewing software to demonstrate aspects of a design 
proposal. They mainly rely on the designers' visuals generated from the BIM model.

- Code validation: BIM is not (yet) used to validate whether the model complies with the building code. Designers perform a variety of checks against existing rules and regulations, for example related to the quantity of daylight available in rooms or the necessary ventilation capacity. These checks are done by hand with the help of simple spreadsheet software. However, the firm recently purchased a license for new software that also turned out to have the ability to validate a model against the building code. At the time of this research, it was decided to investigate the potential of this BIM use for the firm's design practices.

- Drawing production: All drawings are generated from a BIM model. Designers do this by determining from which perspective they want to view the model and with which settings (for example color usages and levels of details). Relevant views include elevation plans, cross-sections and 3D visualizations. One or more views are then put in a framework and complemented with a legend and relevant textual elements (like information on the assembly sequences). In producing a drawing, a designer essentially creates a PDF file or print job from a framework with BIM view(s). No other drawing software is used for making a 2D or 3D drawing from a building design.

- Engineering analyses (structural, lighting, energy, mechanical, other): The firm does not analyze building engineering aspects with BIM. Most of the engineering analyses, for example related to fire loading or energy performance, are outsourced to other consultancy or engineering firms. Those firms typically request a (simpler) geometric 2D or 3D model rather than a BIM model. Shadow analyses are conducted by the focal firm itself though, but those are only rarely requested.

The data do not reveal any other BIM use implementations for the reversible building design practices of this case study's focal firm.

\section{Discussion}

This study explored how BIM can support reversible building design. Eight potential BIM uses were first identified through a review of recent literature. An in-depth case study was then conducted to examine which of these BIM uses were implemented - and how - in the reversible building design practices of a Dutch system builder. Through contrasting the actual BIM use implementations with the theorized ones, this paper contributes with novel insights and recommendations on leveraging BIM for reversible building design. 


\section{Theoretical and practical contributions}

First, the implementation of three BIM uses can fully support reversible building design: design authoring, 3D coordination (clash detection) and drawing production. The findings demonstrate that designers use BIM to efficiently develop three-dimensional representations of a reversible building, although rendering may be tedious (design authoring). Spatial conflicts in the design proposals are identified and collaboratively resolved with clash detection software (3D coordination). Drawings of a building project are generated from a BIM model through defining perspectives and applying desired viewing settings (drawing production). The potentials of these three BIM uses are exploited in the case study's focal firm. The authors therefore classify these as 'key' BIM uses for reversible building design.

Second, the implementation of two BIM uses can partially support reversible building design: quantity take-off (cost estimation) and design review. It was found that the BIM model can be used to generate a bill of quantities (quantity take-off). However, cost estimations are still predominantly based on (additional) manual calculations of quantities of materials. The BIM model can be used to evaluate a building design with a client and to receive feedback on the design intent (design review). Designers nevertheless provide mostly static visuals to the firm's project leaders and have little or no contact with a client themselves. The potentials of these two BIM uses are only partially exploited in the design practices studied. The authors therefore classify these as 'viable' BIM uses for reversible building design.

Third, the implementation of three BIM uses can deficiently support reversible building design: phase planning (4D simulation), code validation and engineering analyses (structural, energy, mechanical, other). In the case study, no evidence was found of 4D simulations to inform the building design (phase planning). The BIM model was also not used to validate the design against the relevant building code (code validation). Simulations and calculations of engineering aspects are not based on BIM (engineering analyses). The potentials of these three BIM uses are deficiently exploited by the designers in this case study. The authors therefore classify these as 'negligible' BIM uses for reversible building design.

This study also offers practical contributions to designers who aim to design reversible buildings. It has identified eight BIM uses for reversible building design. The authors' empirically-based classifications of these uses helps designers in prioritizing and implementing BIM uses. They should start with selecting the key BIM uses (design authoring, 3D coordination and drawing production), followed by the viable BIM uses (quantity take-off and design review). The potentials of the negligible BIM uses (phase planning, code 
validation and engineering analyses) remain unclear. In implementing these uses, designers can expect similar contributions as the ones described in this study when the contexts of their design work are more proximally similar to the one here.

\section{Limitations and further research}

This study has several limitations, from which the authors suggest new directions for research. It is firstly based on a single case study. The rationale behind that is that the focal firm uncommonly designs buildings that can be disassembled and of which the elements can be reused elsewhere. In terms of Yin (2009), this offered a "unique" case. The downside of the single case is that it is unclear to what extent the findings are generalizable beyond the immediate settings of this study. Similar studies as this one, but in varying times and places, can help in answering that question. Another problem concerns the limited insights into the relative benefits of using BIM to design reversible buildings. This study elaborated on how BIM uses are implemented in the context of reversible building design, but cannot accurately answer how much better those design practices are compared to the absence of BIM. Previous work has, for example, suggested that the design process can be more effective if the firm has a higher BIM 'maturity' (Y. Chen, Dib, \& Cox, 2014). More research is therefore needed that relates perceived benefits of BIM uses with the BIM maturity levels within the context of reversible building design.

\section{Conclusion}

This paper has explored how BIM can support reversible building design through an in-depth case study. Eight BIM uses were systematically identified, classified and elaborated on - according to the extent they can support reversible building design. Based on that, three main conclusions are drawn. First, it is concluded that design authoring, 3D coordination (clash detection) and drawing production - classified as key BIM uses - can fully support reversible building design. Second, it is concluded that quantity take-off (cost estimation) and design review classified as viable BIM uses - can partially support reversible building design. Third, it is concluded that phase planning (4D simulation), code validation and engineering analyses (structural, lighting, energy, mechanical, other) - classified as negligible BIM uses - can deficiently support reversible building design. It is hoped that the insights and recommendations this paper provides can assist in selecting BIM uses to design and study tomorrow's reversible buildings. 


\section{Acknowledgements}

Funding from the Horizon 2020 research project 'Buildings as Material Banks: Integrating Materials Passports with Reversible Building Design to Optimise Circular Industrial Value Chains' is gratefully acknowledged.

\section{References}

Akbarnezhad, A., Ong, K. C. G., \& Chandra, L. R. (2014). Economic and environmental assessment of deconstruction strategies using Building Information Modeling. Automation in Construction, 37, 131-144.

Allwood, J. M., Ashby, M. F., Gutowski, T. G., \& Worrell, E. (2011). Material efficiency: A white paper. Resources, Conservation and Recycling, 55(3), 362-381.

Azhar, S. (2011). Building Information Modeling (BIM): Trends, Benefits, Risks, and Challenges for the AEC Industry. Leadership and Management in Engineering, 11(3), 241-252.

Barlish, K., \& Sullivan, K. (2012). How to measure the benefits of BIM - A case study approach. Automation in Construction, 24(0), 149-159.

Bryde, D., Broquetas, M., \& Volm, J. M. (2013). The project benefits of Building Information Modelling (BIM). International Journal of Project Management, 31(7), 971-980.

Castronovo, F., Nikolic, D., Liu, Y., \& Messner, J. (2013, 30-31 October 2013). An evaluation of immersive virtual reality systems for design reviews. Paper presented at the 13th International Conference on Construction Applications of Virtual Reality, London, UK.

Cha, H. S., Kim, K. H., \& Kim, C. K. (2011). Case study on selective demolition method for refurbishing deteriorated residential apartments. Journal of Construction Engineering and Management, 138(2), 294-303.

Chen, Y., Dib, H., \& Cox, R. F. (2014). A measurement model of Building Information Modelling maturity. Construction Innovation, 14(2), 186-209.

Cheshire, D. (2016). Building Revolutions: applying the circular economy to the built environment. Newcastle upon Tyne: RIBA Publishing.

Computer Integrated Construction Research Program. (2010). BIM Project Execution Planning Guide - version 2.0. Retrieved from University Park, PA, USA:

Durmisevic, E. (2006). Transformable building structures: Design for disassembly as a way to introduce sustainable engineering to building design \& construction. Delft University of Technology, Delft.

Eastman, C., Teicholz, P., Sacks, R., \& Liston, K. (2011). BIM Handbook: a guide to Building Information Modeling. Hoboken: John Wiley \& Sons.

Eisenhardt, K. M. (1989). Building theories from case-study research. Academy of Management Review, 14(4), 532-550.

Gorgolewski, M. (2008). Designing with reused building components: some challenges. Building Research \& Information, 36(2), 175-188.

Hartmann, T., \& Fischer, M. (2007). Supporting the constructability review with 3D/4D models. Building Research \& Information, 35(1), 70-80. 
Huuhka, S., \& Lahdensivu, J. (2016). Statistical and geographical study on demolished buildings. Building Research \& Information, 44(1), 73-96.

Iacovidou, E., \& Purnell, P. (2016). Mining the physical infrastructure: Opportunities, barriers and interventions in promoting structural components reuse. Science of the Total Environment, 557, 791-807.

Jalaei, F., \& Jrade, A. (2014). An automated BIM model to conceptually design, analyze, simulate, and assess sustainable building projects. Journal of Construction Engineering, 2014.

Moum, A. (2010). Design team stories: exploring interdisciplinary use of 3D object models in practice. Automation in Construction, 19(5), 554-569.

Sacks, R., Koskela, L., Dave, B. A., \& Owen, R. (2010). Interaction of Lean and Building Information Modeling in Construction. Journal of Construction Engineering and Management, 136(9), 968-980.

Schultmann, F., \& Sunke, N. (2007). Energy-oriented deconstruction and recovery planning. Building Research \& Information, 35(6), 602-615.

Shiratuddin, M. F., \& Thabet, W. (2007). Information rich Virtual Environment (VE) design review. Paper presented at the 24th W78 Conference \& 5th ITCEDU Workshop \& 14ht EG-ICE Workshop, Maribor, Slovenia.

Shiratuddin, M. F., \& Thabet, W. (2011). Utilizing a 3D game engine to develop a virtual design review system. Journal of Information Technology in Construction, 16, 3968.

Succar, B. (2009). Building information modelling framework: A research and delivery foundation for industry stakeholders. Automation in Construction, 18(3), 357375.

Succar, B., Sher, W., \& Williams, A. (2012). Measuring BIM performance: Five metrics. Architectural Engineering and Design Management, 8(2), 120-142.

Trebbe, M., Hartmann, T., \& Dorée, A. G. (2015). 4D CAD models to support the coordination of construction activities between contractors. Automation in Construction, 49, 83-91.

Turk, Ž. (2016). Ten questions concerning Building Information Modelling. Building and Environment, 107, 274-284.

Van den Berg, M., Voordijk, H., \& Adriaanse, A. (2017). Coordinating reverse logistics in construction: mechanisms to manage uncertainties for various disposition scenarios. Paper presented at the IPSERA 2017 Conference, BudapestBalatonfüred.

Won, J., \& Cheng, J. C. P. (2017). Identifying potential opportunities of Building Information Modeling for construction and demolition waste management and minimization. Automation in Construction, 79, 3-18.

Wong, J. K. W., \& Zhou, J. (2015). Enhancing environmental sustainability over building life cycles through green BIM: A review. Automation in Construction, 57, 156-165.

Yin, R. K. (2009). Case Study Research: Design and Methods (4 ed.). Thousand Oaks: Sage. 


\section{Chapter 5}

Supporting design reviews with pre-meeting virtual reality environments

Marc van den Berg, Timo Hartmann \& Robin de Graaf

Published

Van den Berg, M., Hartmann, T., \& De Graaf, R. (2017). Supporting design reviews with pre-meeting virtual reality environments. Journal of Information Technology in Construction, 22(16), 305-321. 


\section{Abstract}

The purpose of this paper is to explore how design reviews can be supported with pre-meeting virtual reality environments. Previous research has not systematically investigated how virtual environments can be used to communicate the design intent (to clients) and to communicate feedback (to design professionals) in advance of review meetings within real-world projects. A prototypical virtual environment that enables clients to individually navigate through and comment on a design-in-progress, aimed to be used before a review meeting, was therefore studied in two typical architectural and engineering design projects. A pattern-matching strategy was applied for the qualitative analysis of the data collected. It is concluded that theoretical expectations and pragmatic realities about the support of pre-meeting virtual reality environments for design review match (yet in varying degrees) in the areas of: exploration from a user perspective, participation in solution-finding and feedback on a design proposal. This paper thereby offers an in-depth understanding about the potential of virtual environment usages in advance of review meetings, which may help design professionals to make a more informed choice about how and why to support design reviews with pre-meeting virtual reality environments.

Keywords: Design management; Design review; Information transferability; Pattern-matching; Virtual environment 

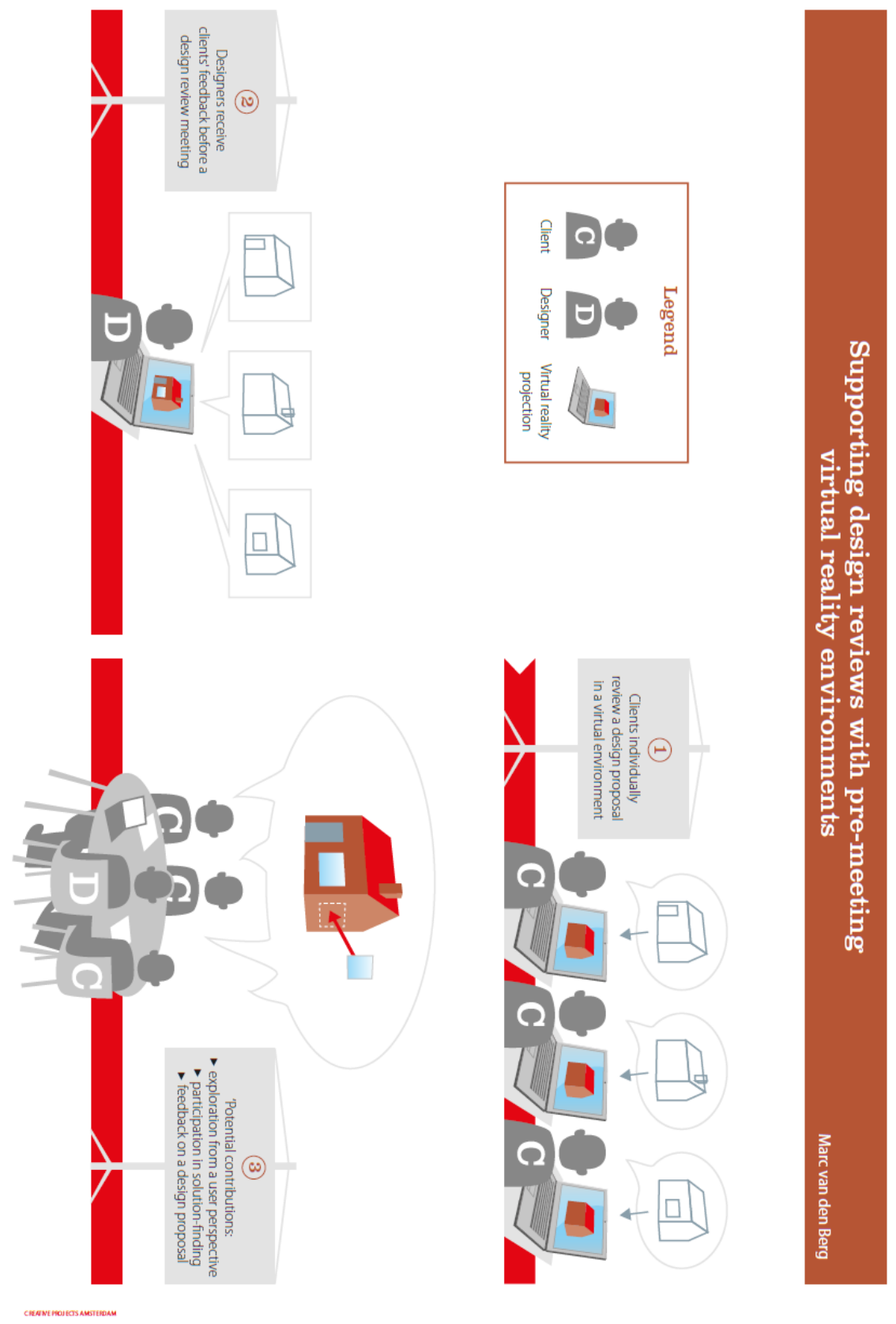


\section{Introduction}

Design review is one of the most important processes in architectural and engineering design (Cárcamo, Trefftz, Acosta, \& Botero, 2014). It is the process of evaluating a design solution to detect any possible failures with respect to program, function of spaces or overall performance (Castronovo et al., 2013). Typically, design reviews take place during regular meetings in which designers/engineers and clients (i.e. building owners and/or end-users) convene to reflect on an unfinished design and decide upon any necessary changes (Le Dantec \& Do, 2009). The design is then talked about in relation to more-or-less clearly defined client judgments, needs, desires, or preexisting conditions of other stakeholders (Oak, 2011). Visualization techniques such as sketches, architectural drawings, mockups or photomontages play an important role in these complex designer-client interactions (Rwamamara, Norberg, Olofsson, \& Lagerqvist, 2010). Design reviews are crucial for timely detecting and identifying discrepancies, errors and inconsistencies in design (Shiratuddin \& Thabet, 2007) and they allow participants to accept and commit to decisions made as a group (Garcia, Kunz, \& Fischer, 2005; Le Dantec \& Do, 2009). However, these objectives are complicated due to profound problems in exchanging and communicating building design information.

Design reviews are often supported with traditional visualizations that provide limited information transferability. It is, by nature, very difficult to convey how a design will look and feel once it is realized (Conniff, Craig, Laing, \& Galán-Díaz, 2010). Particularly inexperienced clients find it often hard to extrapolate the scale of the design to their own scale (Castronovo et al., 2013), while different types of visualizations can easily alter perceptions of a design (Bassanino et al., 2010). Traditional approaches to visualize the design intent have concentrated on static pictures or three-dimensional (3D) scale models, which face expensive design evolution, lack of communication and limited reusability (J. Wang, Wang, Shou, $\& \mathrm{Xu}, 2014)$. The dependency on these visualization approaches in a meeting setting can pose additional problems, including a lack of confidence to express comments in a group (Shen et al., 2013) and constraints in aligning participants' agendas. Altogether, the information flows in design are considered insufficient (Woksepp \& Olofsson, 2008), which can result in an incomplete understanding of proposed design solutions, a lack of involvement in the evaluation process and biased feedback on the design.

This research proposes to address these problems with virtual reality environments that are deployed before a design review meeting. Virtual reality (VR) offers an intuitive medium in which a 3D view can be manipulated in realtime and used collaboratively to explore and analyze design options and 
simulations of the construction process (Bouchlaghem, Shang, Whyte, \& Ganah, 2005). Numerous studies have highlighted the potential of virtual reality for design review (Dunston, Arns, Mcglothlin, Lasker, \& Kushner, 2011; Kumar, Hedrick, Wiacek, \& Messner, 2011; Shiratuddin \& Thabet, 2011), but have not yet explored its possibilities for communicating the design intent (to clients) and subsequent feedback (to design professionals) in advance of actual review meetings. Hence, we aim to provide insights and recommendations on supporting design reviews with pre-meeting virtual reality environments through (I) hypothesizing about their potentials, (II) organizing empirical data collected from real-world projects and (III) attempting to match these theoretical ideals and pragmatic realities.

\section{Theoretical framework}

Virtual reality simulates physical presence in an interactive, three-dimensional setting. Whyte (2002) argues that virtual reality has three defining characteristics: it is (1) interactive, enabling users to manipulate a design model, (2) spatial, with those models being represented in three spatial dimensions and (3) real-time, with feedback from actions given without noticeable pause. These characteristics make it possible to experience a model from the inside, which is substantially different from viewing a 3D (or even $2 \mathrm{D}$ ) representation on a screen. The latter gives the sensation of looking through a window into a miniature world on the other side of the screen, with all the separation that sensation implies, rather than a feeling of depth and immersion (Shiratuddin \& Thabet, 2007). 3D CAD systems assist design specialists in creating precise 3D representations of real objects with certain features (such as volume, weight, etc.), whereas virtual reality allows users to display and manipulate these objects (modeled with surfaces and spaces for realistic representation) in a virtual environment (Woksepp \& Olofsson, 2008). Those virtual environments require the $3 \mathrm{D}$ design models to be imported into virtual reality systems, which are often based on technologies from the computer games industry (Kumar et al., 2011).

Virtual reality has been an area of increasing research and development activities in construction. Scholars and practitioners initially focused primarily on immersive wall-mounted displays (Bowman, Koller, \& Hodges, 1997; Cruz-Neira et al., 1993; Roussos et al., 1999), but improvements in computing technology have later shifted the attention to non-immersive virtual environments running on desktop computers (Koutsabasis, Vosinakis, Malisova, \& Paparounas, 2012; Merrick, Gu, \& Wang, 2011) and immersive head-mounted displays (Froehlich \& Azhar, 2016). Iorio and Taylor (2014), for example, demonstrated the mediating role of boundary objects for conflict management in virtual environments used 
by globally dispersed teams. Woksepp and Olofsson (2006) argue that the use of virtual reality had a positive effect on the final project costs and quality in a largescale industry project. Other scholars have also successfully demonstrated the potential of virtual environments to support planning construction site activities (Gül, 2009; Hartmann \& Fischer, 2007; Li et al., 2008), coordination between different design disciplines (Merrick et al., 2011; Rosenman, Smith, Maher, Ding, \& Marchant, 2007), collaboration in globally dispersed teams (Dossick, 2014; Dossick, Anderson, Iorio, Neff, \& Taylor, 2012; Iorio, Taylor, \& Dossick, 2011) and teaching/training efforts (Sacks, Perlman, \& Barak, 2013; Sampaio \& Martins, 2014). Accordingly, virtual reality environments may be "meaningful, valuable and affordable" (Mobach, 2008, p. 178) for use within the construction industry.

Virtual environments have been proposed for design review accordingly, but with limited attention for asynchronous and remote information transferability in actual projects. Germani, Mengoni, and Peruzzini (2012) discuss four dimensions of design collaborations based on time (synchronous/asynchronous) and space (co-located/remote) combinations. Related works on the topic have mostly focused on virtual reality systems to support design interactions during meetings in which participants meet at the same place (i.e. synchronous and co-located) or at different sites (i.e. synchronous and remote). For example, Majumdar, Fischer, and Schwegler (2006) report on a study where key professionals and decision-makers met inside a Computer Assisted Virtual Environment (CAVE), a room with six projectors optimized for viewing 3D environments in real-time, to review the design of a courtroom. Such expensive and high-end virtual reality solutions are, however, not always available and can be difficult to use in day-today design practices. In addition to that, many studies have overlooked the possibilities of virtual environments to enable clients evaluating a design proposal and communicating feedback from their own time and place (i.e. asynchronous and remote). Indeed, Kim, Wang, Love, Li, and Kang (2013) conclude that very few studies have actually involved industry practitioners. Most studies on virtual environments for design review mainly deal with technical aspects of developing virtual design review systems and lack any empirical evaluations of those systems in use (cf. Chionna, Cirillo, Palmieri, \& Bellone, 2015; Kumar et al., 2011; Shiratuddin \& Thabet, 2007; Yan, Culp, \& Graf, 2011).

Surprisingly, previous research has not systematically investigated how virtual environments can be used to communicate the design intent (to clients) and to communicate feedback (to design professionals) in advance of review meetings within real-world projects. Those works have addressed only one or few of these (italicized) aspects - not all of them together. The extant literature nevertheless allows us to hypothesize about the potential of virtual reality environments, 
which we thematically group in three categories: exploration from a user perspective, participation in solution-finding and feedback on a design proposal.

\section{Exploration from a user perspective}

To start with, some studies indicate that exploring a design proposal from a user perspective may be beneficial for clients. Virtual environments have the capability to present spatial information in a more engaging manner, giving users a better sense of spatial (scale, distance and adjacency) and visual (appearance and view) factors (Eastman et al., 2011; Shen, Shen, \& Sun, 2012). They could thus be used to offer clients a glimpse of a possible future (Mobach, 2008), supporting them in becoming familiar with the look and feel of a realized design (Conniff et al., 2010). That enables clients to recognize how a design proposal meets a problematic situation (Paton \& Dorst, 2011) and facilitates discovering any problematic design issues (Dossick, 2014). Previous works of Shen et al. (2012) and Shen et al. (2013) have, for example, revealed that clients reported to gain a better "overall understanding" of a design when they used a specific tool for visualizing and simulating end-user activities instead of using 3D modeling software. Similarly, Castronovo et al. (2013) argue that virtual reality attributes enable a more qualitative representation of spaces from a user perspective. Based on these studies, we expect that:

- Clients will discover problematic design issues while navigating through a virtual environment, and that;

- They can imagine what the design will look like once it is realized.

\section{Participation in solution-finding}

Other studies also hint at the potential of virtual reality environments to foster client participation in solution-finding. To achieve efficient and effective design collaboration, it is essential that clients participate in the process of finding solutions for design problems (Gül, 2009). Participation nevertheless varies per individual and may also alter during the course of a design project due to the change process and the nature of human behavior (Thyssen, Emmitt, Bonke, \& Kirk-Christoffersen, 2010). Virtual environments aimed at clients may stimulate their participation in the process, since such tools increase their access to design information (Shiratuddin \& Thabet, 2011) and because the possibility to navigate in an as-yet-unbuilt environment is appealing in itself (Conniff et al., 2010). Users of the review tools of Shen et al. (2012) and Shen et al. (2013) also reported to be "more willing to work together with designers to improve a design" than 
people specifying feedback on a design with conventional paper-based methods. That willingness may manifest itself in the engagement in discussing and optimizing design issues (Jensen, 2011). Earlier work furthermore demonstrated that more introverted persons are more comfortable with the possibility to give feedback individually (Shen et al., 2012; Shen et al., 2013). In line with that, Bassanino, Fernando, and Wu (2014) conclude that the possibility to evaluate a design proposal on one's own screen provides users privacy, which may encourage clients' willingness and confidence to collaborate with designers. Based on this, we expect that:

- Clients feel empowered to contribute building the design solution further with their feedback;

- They participate actively in discussions about design issues they previously identified themselves during virtual walkthroughs, and that;

- Those clients who regard themselves as introverted feel comfortable to express feedback.

\section{Feedback on a design proposal}

Literature also suggests that virtual reality environments could be utilized to capture feedback of clients. Cross $(2008$, p. 13 ) argues that a client generally "does not know what the 'answer' [to a design problem] is, but they will recognize it when they see it." With feedback, a client indicates that the right answer is not yet found: it points to key areas for improvement (Salter \& Torbett, 2003). Useful feedback provides new insights with the potential to impact on the subsequent design process (Følstad, Hornbæk, \& Ulleberg, 2013). A previous study with an immersive virtual environment revealed that most of the feedback expressed there dealt with forward looking actions such as suggesting changes for important parts of the design (Majumdar et al., 2006). Similarly, the experiment of Shen et al. (2013) revealed that the use of a visualization and simulation tool led to significantly more suggestions for improvement of the proposed design. Designers can use such feedback to determine whether the proposed design is what the client envisioned (Shiratuddin \& Thabet, 2007) and to plan on taking action for ensuring acceptance and appreciation of the building design (Jensen, 2011). Based on this, we expect that:

- Feedback expressed in a virtual environment considers a key part of the design and is suited to contribute to a change in that design, and that;

- Designers regard the feedback expressed in a virtual environment as helpful to guide the design process. 


\section{Research methodology}

The goal of this research is to explore how design reviews can be supported with pre-meeting virtual reality environments. We developed a tool ourselves based on jMonkeyEngine 3.0, a Java-based game engine coupled with an integrated development environment. The non-immersive tool runs on a laptop with average processing power and does not require a head-mounted device. It essentially enables clients to navigate in first-person through a design-inprogress using keyboard and mouse and then to type feedback in a textbox that appears when they click on an object somewhere in the model. The feedback that is stored consists of information about the object that was clicked on, a screenshot and the text entered. While this tool is novel in itself, we were interested here in how it supports actual design reviews in terms of the aforementioned categories: exploration from a user perspective, participation in solution-finding and feedback on a design proposal. We thus implemented and studied the use of this virtual environment in two typical architectural and engineering design projects. Subsequently, we applied a pattern-matching strategy for the qualitative analysis of data collected in these two cases.

\section{Case I: draft design of a parking garage}

The first case concerns the draft design of a parking garage in Amsterdam, the Netherlands. At the time of our study, the draft design phase was finished and no decision had been taken yet to proceed to the preliminary design phase. Two (out of three) client representatives in this project were nevertheless available and willing to evaluate the draft design like they would do if the design would be elaborated into a preliminary design. We thus collected the design files (nonparametric model and 2D CAD drawings) from the designers and prepared a virtual environment: we imported these files in the game engine, set up an interactive, navigable scene and applied basic colors and textures to the 3D geometry - corresponding to the conceptual level of the draft design stage. We then organized two individual review sessions, with the clients making a virtual walkthrough and commenting on certain objects in the design. We also combined this feedback in a report and handed that over to the designers. Although no review meeting could be scheduled afterwards, the data collected yielded important insights on the use of the virtual reality tool that justify the inclusion of this case in our study. During earlier review meetings, not included in this study, the designers had nevertheless predominantly relied on 2D representations to convey the design intent. 


\section{Case II: definitive design of water production plants}

The second case concerns the definitive design of three plants for the production of drinking water: a pump, filter and softening plant located in the South of the Netherlands. While the scheduled design review dealt with these three plants, we only imported the first two in the virtual environment so that we could make some comparisons. A few days before the review meeting, we received the design files (Building Information Model (BIM) and 3D CAD drawings) and consequently prepared the virtual environment in a similar way as described above. The focus of the subsequent review meeting here was on engineering features, with colors of pipes, installations and other engineering systems indicating certain production steps, and thus little attention was paid to the rendering quality. Before the review meeting, we held individual review sessions with six persons having different roles and backgrounds in the design project most of them would eventually work in the renewed production plants. We combined all their feedback in a report for the designers. They could use that report to prepare for the review meeting. A few days later, twenty persons attended that meeting - three of them had used the virtual environment. The designers used $3 \mathrm{D}$ viewing software here to show the definitive design on a projection screen. All of the designers were familiar with the design and would each verbally introduce some parts of the design, but only one of them was in charge of manipulating (e.g. zooming in/out or rotating) the view shown on the projection screen. During the consequent design discussions, both clients and designers referred to these $3 \mathrm{D}$ views.

\section{Data collection: using multiple sources from case studies}

In an attempt to achieve data triangulation, we collected data from multiple different sources - for which these two cases provided abundant opportunities. In both cases, we visited the clients participating in our study in their own offices and observed them making a virtual walkthrough and commenting on design proposals. After these individual sessions, we asked them to reflect on their software use during semi-structured interviews. We recorded the review meeting that (in the second case) followed these sessions, thereby following video research guidelines of Derry (2007) and Jordan and Henderson (1995). As such, we applied a coding scheme based on the hypotheses to the video data; essentially splitting the review meeting in distinct parts and then coding the content (i.e. 'design discussion', 'taking stock of progress' or 'coordination activity'), noting the specific persons contributing to that meeting part (i.e. marking names) and identifying whether a review topic was previously identified with the use of the prototypical virtual environment or not (one or zero). The 126 | Supporting design reviews with pre-meeting virtual reality environments 
coding resulted in an extensive case-by-variable matrix of the video data (Bernard \& Ryan, 2010), which turned out to be an illuminating data source. Data was also collected with short, qualitative pre- and post-meeting questionnaires to capture perceptions that could not be observed or recorded directly. Finally, a few days after the review meeting, we collected the meeting's minutes and other project documentation and held eleven telephonic semi-structured interviews with (six) persons who had used the virtual environment in advance of the meeting and (five) who had not. With the permission of the respondents, all these interviews were recorded on audiotapes and transcribed verbatim thereafter for further analysis.

\section{Data analysis: applying a pattern-matching strategy}

For the analysis of the data collected, we applied a pattern-matching strategy. Pattern-matching is one of the most desirable strategies to deal with the relatively unstructured nature of qualitative data (Trochim, 1989; Yin, 2009). It is about comparing the 'theoretical ideals' with the 'pragmatic reality,' which will enhance critical understanding and learning (Cao, Clarke, \& Lehaney, 2004; De Graaf \& Dewulf, 2010). Pattern-matching involves (I) the specification of a theoretical pattern, (II) the acquisition of an empirical pattern and (III) an attempt to match those two (Figure 5) (Trochim, 1989). A theoretical pattern describes what is expected in the data (the theoretical ideal), while an empirical pattern consists of the actual data found in real-life cases (the pragmatic reality). For the

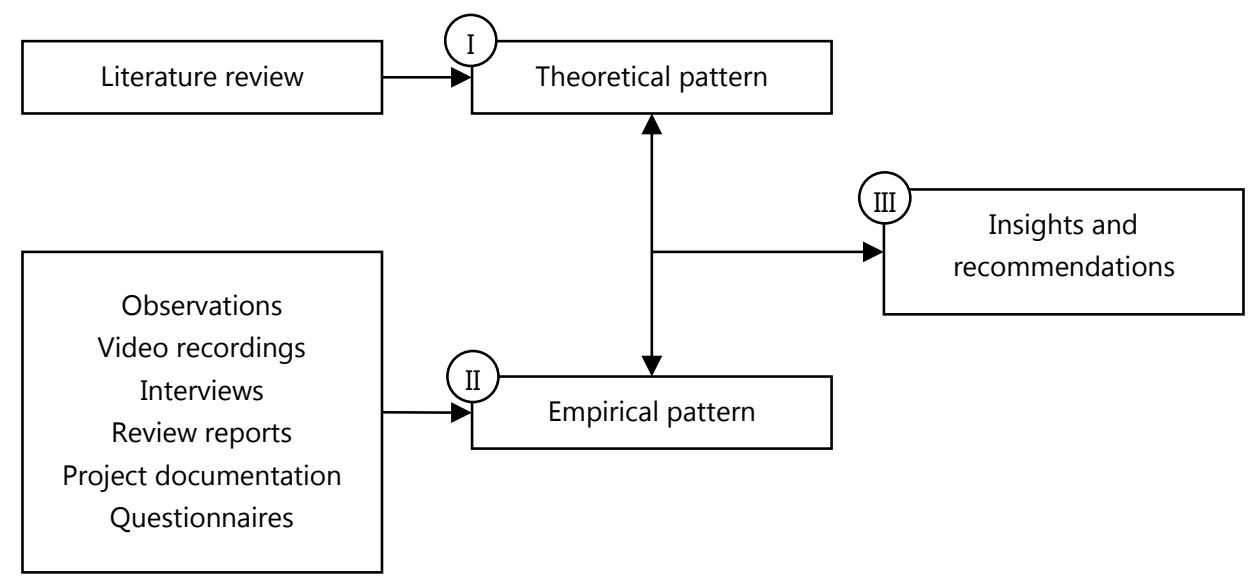

Figure 5: Research model visualizing how this study (I) specifies a theoretical pattern, (II) organizes the data in an empirical pattern and (III) compares both with each other 
latter, we examined, categorized and recombined the multiple data sources "in search for patterns in the data and for ideas that help explain why those patterns are there in the first place" (Bernard \& Ryan, 2010, p. 109). Provided that the theoretical and empirical pattern are parallel in structure, they can be compared with each other to assess whether the theories predicting the observations receive support. Both the theoretical pattern (as specified above) and the empirical pattern (as specified in the upcoming section) are therefore structured in three categories: exploration from a user perspective, participation in solutionfinding and feedback on a design proposal.

\section{Results}

This section organizes the findings from the two real-world case-studies in an empirical pattern that is parallel in structure to the theoretical pattern.

\section{Exploration from a user perspective}

The first part of the empirical pattern considers exploration from a user perspective. From observing the usages of the pre-meeting virtual reality environment, we found that clients discovered issues in the design that could potentially be problematic. In the parking garage case, for example, the technical advisor noticed "a strange corner" when making a virtual walkthrough (Figure 6, left). He was so surprised that he looked for an explanation in some drawings he brought with him, but eventually left the next comment in the virtual environment: "Strange corner, seems not socially secure! Is this a parking lot?" Similarly, the project leader found out what it will look like if cars are parked on a small slope of $7 \%$ (Figure 6, right). Although that design feature had been a major topic of discussion in previous design review meetings, the virtual walkthrough offered a user perspective, which helped him recognizing the implications of parking on a slope for the first time.

The virtual environment usages in the water production plants case resulted in similar discoveries. The project employee Service \& Maintenance, for example, found that one large pipe section was incomplete (Figure 7, left). However, from his comment in the virtual environment it appears that he realized this might not be an error at all, but a result of a change in the water production process: "there are valves missing from the basement (maybe this becomes single filtrate, then this is not necessary)." Other persons knew that removing this pipe was correct and - independent of the previous person - commented in the virtual 

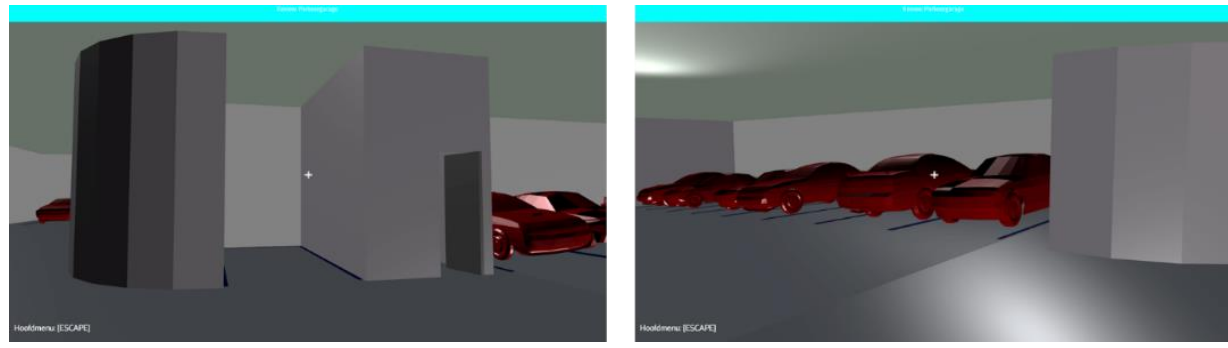

Figure 6: Discoveries in the parking garage case: a "strange corner" that is actually a parking lot (left) and parking lots on a slope (right)
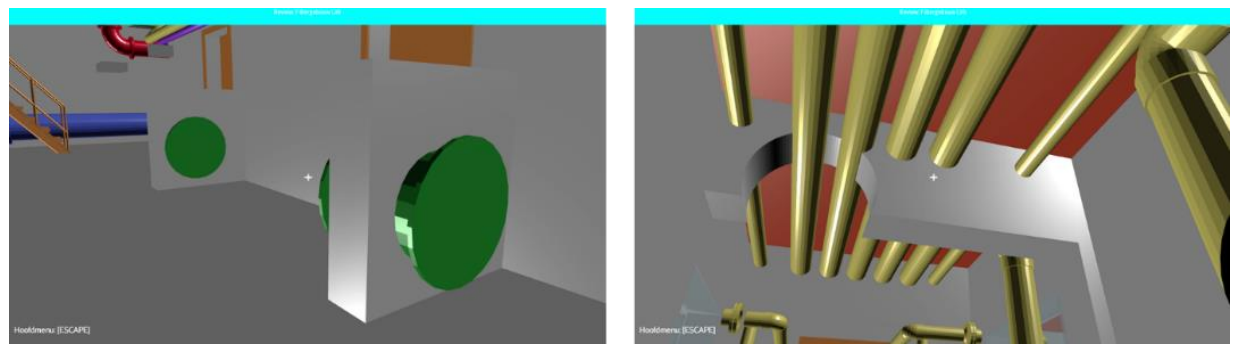

Figure 7: Discoveries in the water production plants case: an unconnected pipe section (left) and a potential error in the number of pipes (right)

environment to "take out" the remaining pipe and wall piece. Another issue discovered in the virtual environment was a potential error in the number of tubes for the air intake, being either four or five (Figure 7, right). When the process technologist noticed this, he walked back and forth and looked around in the virtual environment to count the number of tubes and to see how they ran through the corridor. During the review meeting, this person referred back to his earlier discovery and asked the designers to clarify this part of the design - which demonstrates that he had become more familiar with the design than most of the other attendees who had not used the virtual environment.

Clients using the virtual environment also reported being able to imagine what the future building would look like in reality. One client in the water production plants case said that he "gained a very good mental image [due to the virtual environment]. We could walk properly through the buildings. I could see the technical aspects [...] very well. Visually, the colors and the like, it is powerful, and also the details were visible." Another client said that he had gained a good mental picture of the buildings because he could navigate through them himself this time, "which is easier than evaluating 2D drawings." Similarly, a client in the parking garage case argued the following: 
"One can also see certain design features, like parking on a slope and the fact that there are no structural columns, at a drawing. But if you see those things in such a [virtual environment], you get a better impression of it." - Project leader

In both cases, the interview data reveal that the clients attributed their understanding of the design proposal to their individual walkthroughs in the three-dimensional space.

\section{Participation in solution-finding}

The second part of the empirical pattern deals with the participation of clients in solution-finding. Our interview data reveal that users of the pre-meeting virtual reality environment expected that designers would respond properly to their feedback on the design. These clients were all enthusiastic about making a virtual walkthrough, making comments like "it is actually fun" and "nice that you can see all of this." They were also pleased with the feedback functionality that the tool provides them; one client in the parking garage case described this as "a really surprising feature." Several clients in the water production plants case believe that the designers will handle the virtual environment feedback carefully. As such, one client in the water production plants case could not attend the review meeting, but recognized from the meeting's minutes that his virtual environment comments were nevertheless "put into work carefully." Other users of the tool also thought that their comments would be meaningful to further improve the design. As such, one client said the following:

"We are men of the work floor and we see other things. It seems to me that [the designers] will do at least something with those suggestions of us. Especially when also other people of our workplace talk about the same, I expect [they] are going to do something with it." - Project employee Service \& Maintenance

And another client in the same case formulated his expectations as follows:

"I expressed my comments [in the virtual environment]. I don't decide about those comments myself, but I assume [the designers] will do something with my comments. Not all comments will be accepted, but some will. [...] Because of that, I feel more involved with the project." - Process technologist

These clients also joined (and occasionally started) discussions about issues they had identified in the virtual environment before the meeting. The video transcription revealed that sixty-three design issues were raised during the meeting. Although three users of the virtual environment were not present at the design review meeting, the other users participated (six times) in such design discussions. As an example, one said: "I understood the shape of the rungs [of 130 | Supporting design reviews with pre-meeting virtual reality environments 
the cage ladders] is rectangular" and then started a discussion about the ease of holding such a shape. In the virtual environment he had already identified the shape of the rungs as an ergonomics issue (Figure 8 , left). As another example, one process technologist did not understand what some "barrels" in one of the buildings were meant for and subsequently formulated a question in the virtual environment (Figure 8, right). While an answer had initially not become clear during the review meeting, he brought the subject forward again and learned that these 'barrels' need to reduce the effects of 'water hammer': a pressure-wave resulting from the sudden closure of a valve. Contrasting evidence was nevertheless found as well: some earlier identified issues (e.g. on the location of lifting beams or the spatial layout of the corridor) were only implicitly addressed during the meeting and the participation of the reviewing client was there rather limited.

It nevertheless appeared that clients felt at ease with sharing their concerns during the design review meeting. Most of them said they "did not feel uncomfortable" to share their feedback on the design proposal during the meeting with the designers. Only one person explicitly confirmed feeling a barrier to talk in large groups:

"I am not someone who likes to be in the picture and takes the initiative. I always let other people have their say first. I am biding. I always think that there are other people who like to say something first [during a meeting]. Oftentimes, the points I would like to discuss are then already brought forward. In that case, I don't have to say them myself." - Project employee Service \& Maintenance

When we asked this person what could make him more comfortable in these situations, he answered that individual sessions, "like you just did," could work for him. "For me that is more efficient than working in a big group." This
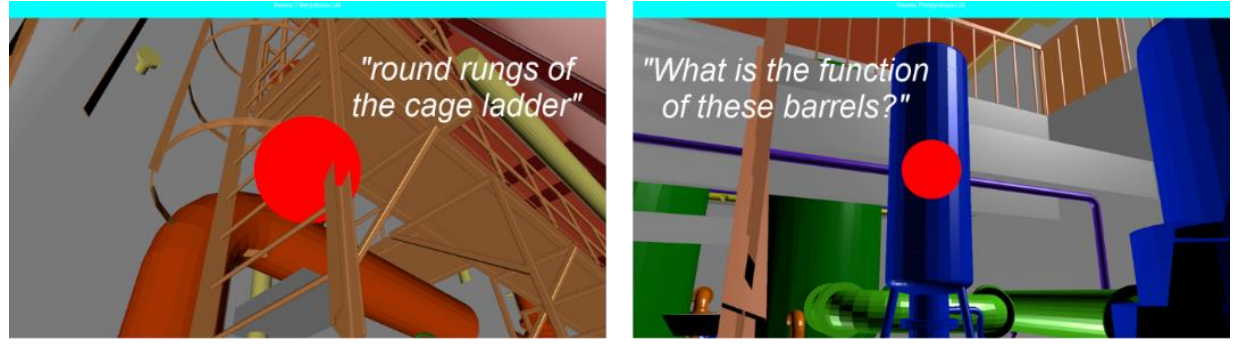

Figure 8: Examples of feedback on a design proposal (text pasted on original screenshots). Clients participate in design discussions about issues they previously identified in the virtual environment: the ergonomics of holding a specific type of rungs of a cage ladder (left) and the function of some "barrels" in the basement of the proposed design (right) 
statement was also backed up by the designers, who explicitly mentioned that this particular person "had come out of his shell" and "contributed much more" than they were used to from previous meetings (without the use of a virtual environment beforehand). Our finding is furthermore supported by the views of most other clients, who suggested "individual sessions" or "smaller groups" as a way to increase the participation of introverted people during the design reviews. Even though few clients felt a barrier to express their concerns during a review meeting, individual review sessions with a virtual environment are still seen as helpful for introverted persons to collaborate with designers for improving a design.

\section{Feedback on a design proposal}

The third part of the empirical pattern considers feedback on a design proposal. From analyzing the review reports, it seems that a large part of the feedback points to a key part of the design and may lead to a design change. The individual review sessions with the virtual environment each resulted in one to twelve comments (thirty-three in total). A large part of the feedback pointed to details that would only be addressed in a later design phase or did not build the solution further (e.g. feedback concerning the position of emergency exit signs or fire extinguishers). Other feedback given in the virtual environment was nevertheless considered as relevant and could contribute to a change in the design. One comment on the design of the filter plant, for example, suggests to "include a sliding gate so that it will be easier to lift heavy materials or equipment." As employees need to perform lifting operations quite regularly and ergonomics had been an important design concern, this comment has great potential to lead to a change in the design. Similarly, other comments in the same case raised attention to undesirable working conditions for (some of) the clients' future workplace, such as high noise levels of eight air blowers (Figure 9, left) and the lack of partitions to protect from falling down (Figure 9, right).

In the parking garage case, most of the comments also seemed relevant with the potential to impact on the design. These individual review sessions resulted in four and five comments (nine in total). As such, one of the clients noted that the ceiling is "quite high" at some point in the garage and suggested that this height could be used at ground level, for example for trees or mechanical, electrical and plumbing (MEP) systems (Figure 10, left). Since the construction site is exceptionally small in this particular project, the comment provides a new insight for dealing with an important constraint. Another comment dealt with the entrance of a stairwell that is not clearly visible according to the client. $\mathrm{He}$ 

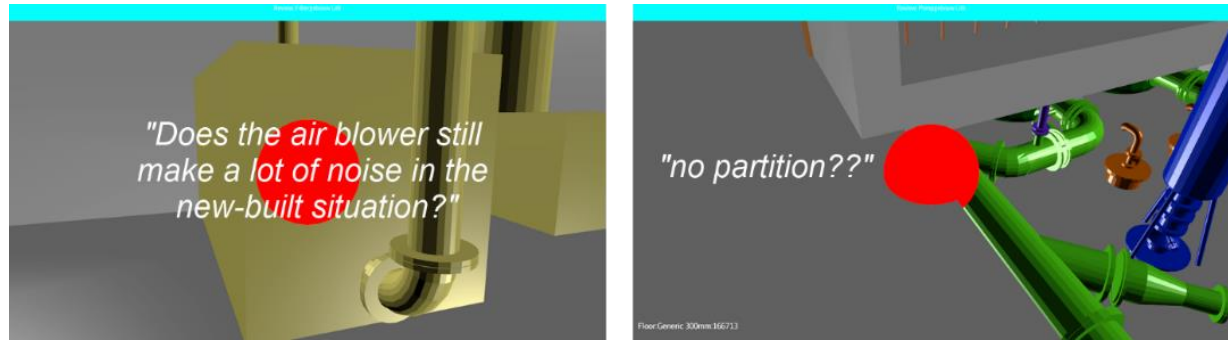

Figure 9: Examples of feedback on a design proposal in the water production plants case (text pasted on original screenshots): a comment about the noise level produced by a number of air blowers (left) and a comment about the absence of partitions to protect from falling down (right)
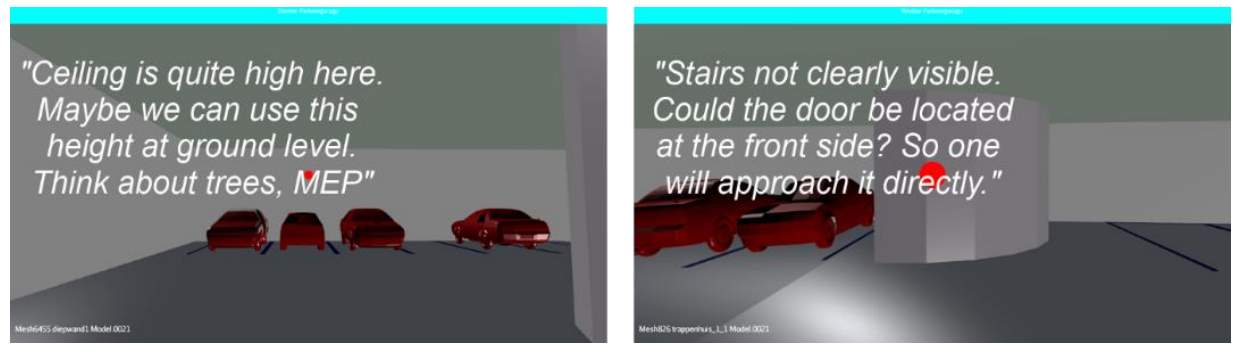

Figure 10: Examples of feedback on a design proposal in the parking garage case (text pasted on original screenshots): a suggestion to lower the ceiling of the parking garage (left) and a suggestion to relocate the door of the stairwell to the front side to make it better visible (right)

suggested relocating it "so one will approach it directly" (Figure 10, right). An important requirement is the accessibility of the parking garage for pedestrians, for which this comment makes constructive input.

In line with this, the interviews revealed that designers consider the feedback expressed in the virtual reality tool as helpful. We observed that the feedback on the design proposal for the parking garage was seen as supportive for the design process as a whole. One of the designers in the water production plants case, on the other hand, regarded most of the comments as "actually too detailed," and thus not appropriate for the related design stage, "but we will deal with those anyway." Another designer also believed that some comments dealt with "minor issues," but similarly revealed that those were still very valuable. He argued that the virtual environment feedback was "helping [him] a lot to understand the [clients] well." Because he already read the virtual environment review reports before the start of the meeting, he could "respond well, listen to them carefully and retort properly" during that meeting. Indeed, a comparison of the video transcription and the review reports revealed that designers and clients agreed 
upon a solution for twenty-four (out of sixty-three) issues that were raised during the meeting, while the other thirty-nine were noted for future consideration. Ten issues had already been identified in the virtual environment before the start of the meeting. Although the last-mentioned designer was initially a bit skeptical about the virtual environment reviews, he later admitted that resulting comments exceeded his expectations: "it could result in an unmanageable amount of bottlenecks that would need to be resolved. [...] I was a little bit afraid for that, but this appeared not to be the case. It actually had a very positive effect." It thus turns out that the designers considered feedback on the design proposals as helpful for the design process, even though they find some comments too detailed for the then current design stage.

\section{Discussion}

In this paper, we explored how design reviews can be supported with premeeting virtual reality environments. Unique to this research are the in-depth insights of actual virtual environment usages before a design review meeting that are contrasted with hypothesized usages. The novel tool that we developed and implemented in two real-world projects aimed to assist in communicating the design intent (to clients) and in communicating subsequent feedback (to design professionals) in advance of actual review meetings. As our contributions, we provide insights and recommendations here through systematically matching our findings (organized in an empirical pattern) with our previously formulated expectations (organized in a theoretical pattern). We then discuss the limitations and suggest directions for future research.

\section{Contributions: insights and recommendations from pattern-matching}

As this study's first contribution, pattern-matching is applied in terms of exploration from a user perspective (Table 13). Starting with the theoretical pattern, we expected that clients would discover problematic design issues while navigating through a virtual environment and that they would be able to imagine what the design will look like once it is realized (cf. Castronovo et al., 2013; Conniff et al., 2010; Paton \& Dorst, 2011). For the empirical pattern, we found that clients using the virtual environment discovered issues in the design that could be problematic. An example is the identification of an isolated parking lot that "seems not socially secure" (technical advisor, case I) and needs to be resolved before the design is finalized. The discovery of an incomplete pipe section was only potentially problematic since the reviewing client realized that 
Table 13: Pattern-matching: exploration from a user perspective

\begin{tabular}{|c|c|c|c|}
\hline Theoretical pattern & Empirical pattern & Exemplary evidence & Match \\
\hline $\begin{array}{l}\text { Clients discover } \\
\text { problematic design } \\
\text { issues while } \\
\text { navigating through a } \\
\text { virtual environment }\end{array}$ & $\begin{array}{l}\text { Clients using the } \\
\text { virtual environment } \\
\text { discovered issues in } \\
\text { the design that } \\
\text { could be } \\
\text { problematic }\end{array}$ & $\begin{array}{l}\text { Discovery of a strange corner that is } \\
\text { actually a parking lot (observation), } \\
\text { statement of having found a "strange } \\
\text { corner" during the virtual walkthrough } \\
\text { (interview), and a screenshot with } \\
\text { written comment "Strange corner, } \\
\text { seems not socially secure! Is this a } \\
\text { parking lot?" (review report) [technical } \\
\text { advisor | case I] } \\
\text { Discovery of a large incomplete pipe } \\
\text { section (observation), statement that } \\
\text { a possible error in the design was } \\
\text { found (interview), and a screenshot } \\
\text { with written comment "there are } \\
\text { valves missing from the basement } \\
\text { (maybe this becomes single filtrate - } \\
\text { then this is not necessary)" (review } \\
\text { report) [project employee Service \& } \\
\text { Maintenance | case II] }\end{array}$ & yes \\
\hline $\begin{array}{l}\text { Clients can imagine } \\
\text { what the design will } \\
\text { look like once it is } \\
\text { realized }\end{array}$ & $\begin{array}{l}\text { Clients were able to } \\
\text { imagine what the } \\
\text { future building } \\
\text { would look like in } \\
\text { reality }\end{array}$ & $\begin{array}{l}\text { Noting the implications of design } \\
\text { decisions such as 'parking on a slope' } \\
\text { during the review (observation), the } \\
\text { comment "One can also see certain } \\
\text { design features, like parking on a } \\
\text { slope and the fact that there are no } \\
\text { structural columns, at a drawing. But if } \\
\text { you see those things in such a [virtual } \\
\text { environment], you get a better } \\
\text { impression of it." (interview) [project } \\
\text { leader | case I] } \\
\text { Recognition how the design changes } \\
\text { the already existing building } \\
\text { (observation), comments of having } \\
\text { "gained a very good mental image" } \\
\text { and "I could see the technical aspects } \\
\text { [...] very well. Visually, the colors and } \\
\text { the like, it is powerful, and also the } \\
\text { details were visible" (interview) } \\
\text { [project leader (1) | case II] }\end{array}$ & yes \\
\hline
\end{tabular}

the water production process could "become single filtrate - then [solving the issue] is not necessary" (project employee Service \& Maintenance, case II). Next to this, our interviews and observations of clients using the virtual environment 
both suggest that clients were able to imagine what the future building would look like in reality. Through virtually experiencing the proposed building from the inside, clients recognized the implications of design decisions such as parking on a slope (case I) or production process changes (case II).

As for the second contribution, pattern-matching is applied in terms of participation in solution-finding (Table 14). The theoretical pattern outlines our expectations that clients using the virtual environment before a review meeting would feel empowered to contribute building the design solution further with their feedback, would actively participate in discussions about design issues they previously identified themselves during their virtual walkthroughs and that those who regard themselves as introverted would feel comfortable to express feedback (cf. Bassanino et al., 2014; Jensen, 2011; Shen et al., 2012; Shen et al., 2013). Organized into an empirical pattern, we found that clients welcomed the feedback functionality and expected that designers would respond properly to their feedback. The virtual environment offered individuals to comment on the design proposal from their own perspective. The individual comments were sent around with the review meeting's minutes (case II), from which it was already concluded that the designers would deal with comments properly. We also presented evidence that clients sometimes joined (and occasionally started) design discussions about issues they had already identified in the virtual environment. An example is that a client had typed feedback about a specific type of cage ladder in the virtual environment, referred to that feedback during the meeting and participated in a resulting ergonomics discussion about the issue at hand (case II). Finally, we found that clients saw individual review sessions with a virtual environment as helpful for introverted persons, even though most people did not feel uncomfortable to share concerns during a meeting with the designers. One interviewee argued that he experienced a barrier to talk and join discussions, but that preparatory sessions with a virtual environment could work for him. Observations, video-recordings and interviews with others support his contributions to the design review (case II). Accordingly, preparatory review sessions were considered beneficial to acquire client input (case I, II).

As for the third contribution, pattern-matching is applied to feedback on a design proposal (Table 15). According to the theoretical pattern, we expected that feedback expressed in the virtual environment would concern a key part of the design and be suited to contribute to a change in that design, as well as that designers would regard that feedback as helpful to guide the design process (cf. Følstad et al., 2013; Majumdar et al., 2006; Salter \& Torbett, 2003; Shiratuddin \& Thabet, 2007). Structured into an empirical pattern, we found that some feedback 
Table 14: Pattern-matching: participation in solution-finding

\begin{tabular}{|c|c|c|c|}
\hline Theoretical pattern & Empirical pattern & Exemplary evidence & Match \\
\hline $\begin{array}{l}\text { Clients feel } \\
\text { empowered to } \\
\text { contribute building } \\
\text { the design solution } \\
\text { further with their } \\
\text { feedback }\end{array}$ & $\begin{array}{l}\text { Clients welcomed the } \\
\text { feedback } \\
\text { functionality and } \\
\text { expected that } \\
\text { designers would } \\
\text { respond properly to } \\
\text { their feedback }\end{array}$ & $\begin{array}{l}\text { Expectation that individual comments } \\
\text { are meaningful: "We are men of the } \\
\text { work floor and we see other things" } \\
\text { (interview), sharing of individual } \\
\text { review reports with minutes of the } \\
\text { design review meeting (project } \\
\text { documentation) and the related } \\
\text { remark that the individual comments } \\
\text { will thus be "put into work carefully" } \\
\text { (interview) [project employee Service } \\
\& \text { Maintenance | case II] } \\
\text { Appreciative comments that making a } \\
\text { virtual walkthrough "is actually fun" } \\
\text { (observation) and the comment that } \\
\text { the feedback functionality "is a really } \\
\text { surprising feature" (interview) } \\
\text { [technical advisor | case I] }\end{array}$ & yes \\
\hline $\begin{array}{l}\text { Clients actively } \\
\text { participate in } \\
\text { discussions about } \\
\text { design issues they } \\
\text { previously identified } \\
\text { themselves during } \\
\text { their virtual } \\
\text { walkthroughs }\end{array}$ & $\begin{array}{l}\text { Clients joined (and } \\
\text { occasionally started) } \\
\text { discussions about } \\
\text { issues they had } \\
\text { previously identified } \\
\text { - yet sometimes their } \\
\text { participation was } \\
\text { limited }\end{array}$ & $\begin{array}{l}\text { Screenshot with comment "round } \\
\text { rungs of the cage ladder" (review } \\
\text { report), meeting comment "I } \\
\text { understood the shape of the rungs } \\
\text { [of the cage ladder] is rectangular" } \\
\text { (video recording) and subsequent } \\
\text { ergonomics discussion (observation, } \\
\text { video recording) [project leader (1)| } \\
\text { case II] } \\
\text { Screenshot with question "What is } \\
\text { the function of these barrels?", similar } \\
\text { question and answer during the } \\
\text { review meeting (observation, video } \\
\text { recording) [process technologist | } \\
\text { case II) }\end{array}$ & partly \\
\hline $\begin{array}{l}\text { Clients who regard } \\
\text { themselves as } \\
\text { introverted feel } \\
\text { comfortable to } \\
\text { express feedback }\end{array}$ & $\begin{array}{l}\text { Clients saw individual } \\
\text { review sessions with } \\
\text { a virtual environment } \\
\text { as helpful for } \\
\text { introverted persons, } \\
\text { even though most } \\
\text { people did not feel } \\
\text { uncomfortable to } \\
\text { share concerns } \\
\text { during a meeting } \\
\text { with the designers }\end{array}$ & $\begin{array}{l}\text { Comments of "not feeling } \\
\text { uncomfortable" or "no barrier to join } \\
\text { discussions" (interviews) [process } \\
\text { technologist, safety expert | case II] } \\
\text { Comment "I always think that there } \\
\text { are other people who like to say } \\
\text { something first [during a meeting]. } \\
\text { Oftentimes, the points I would like to } \\
\text { discuss are then already brought } \\
\text { forward. In that case, I don't have to } \\
\text { say them myself." (interview), client }\end{array}$ & yes \\
\hline
\end{tabular}


Table 14: Pattern-matching: participation in solution-finding (continued)

\begin{tabular}{|c|c|c|c|}
\hline Theoretical pattern & Empirical pattern & Exemplary evidence & Match \\
\hline & & $\begin{array}{l}\text {... participation in the meeting } \\
\text { (observation, video recording) and } \\
\text { designer comment that this person } \\
\text { "had come out of his shell" and } \\
\text { "contributed much more" (interview) } \\
\text { [project employee Service \& } \\
\text { Maintenance, project leader (2) |- } \\
\text { case II] } \\
\text { Comment that "individual sessions" } \\
\text { are most beneficial to acquire input } \\
\text { (interview) [project employee Service } \\
\text { \& Maintenance | case I] }\end{array}$ & \\
\hline
\end{tabular}

expressed in the virtual environment pointed to details that are only relevant in a later design phase. Examples are screenshots and written comments related to details such as emergency exit signs and fire extinguishers (case II). Other feedback dealt with novel insights that could lead to a change in the design though, such as the suggestion to use part of the parking garage's floor-toceiling height at ground level (case I) or the suggestion to include a sliding gate in the production plant to ease lifting of heavy equipment (case II). We also found that designers considered the feedback expressed in the virtual environment as helpful for the design process, even though some of the feedback is considered as too detailed for the relevant design stage. Designers considered the feedback as supportive for the design process as a whole (case I, II) and particularly to prepare better for the design review meeting (case II).

The three main research contributions above have important implications for practice. Through contrasting 'theoretical ideals' with 'pragmatic realities,' we provided detailed insights into how virtual reality environments can be used by designers and clients in advance of design review meetings. Design and engineering firms can benefit from those insights by making a more informed choice about how (and why) to support design reviews with pre-meeting virtual reality environments. Such firms can expect comparable information transferability potential in upcoming design reviews that are more proximally similar to the settings, places and times of this study (Trochim, 1989). When designers offer their clients to individually evaluate a design-in-progress some days before a review meeting with them, they can expect benefits related to explorations from a user perspective, participation in solution-finding and feedback on a design proposal. However, this comes at the expense of additional 
Table 15: Pattern-matching: feedback on a design proposal

\begin{tabular}{|c|c|c|c|}
\hline Theoretical pattern & Empirical pattern & Exemplary evidence & Match \\
\hline $\begin{array}{l}\text { Feedback expressed } \\
\text { in the virtual } \\
\text { environment } \\
\text { concerns a key part } \\
\text { of the design and is } \\
\text { suited to contribute } \\
\text { to a change in that } \\
\text { design }\end{array}$ & $\begin{array}{l}\text { Some feedback } \\
\text { expressed in the } \\
\text { virtual environment } \\
\text { pointed to details } \\
\text { that are only } \\
\text { relevant in a later } \\
\text { design phase, but } \\
\text { another part seemed } \\
\text { relevant and could } \\
\text { contribute to a } \\
\text { change in the design }\end{array}$ & $\begin{array}{l}\text { Contradictory screenshots and written } \\
\text { comments related to emergency exit } \\
\text { signs or fire extinguishers (review } \\
\text { report) [process technologist, safety } \\
\text { expert | case II] } \\
\text { Screenshot and written comment } \\
\text { "Ceiling is quite high here. Maybe we } \\
\text { can use this height at ground level. } \\
\text { Think about trees, MEP." (review } \\
\text { report) [technical advisor | case I] } \\
\text { Screenshot and written comment to } \\
\text { "include a sliding gate so that it will } \\
\text { be easier to lift heavy materials or } \\
\text { equipment" (review report) [process } \\
\text { technologist | case II] }\end{array}$ & partly \\
\hline $\begin{array}{l}\text { Designers regard the } \\
\text { feedback expressed } \\
\text { in the virtual } \\
\text { environment as } \\
\text { helpful to guide the } \\
\text { design process }\end{array}$ & $\begin{array}{l}\text { Even though some } \\
\text { feedback is } \\
\text { considered as too } \\
\text { detailed for the } \\
\text { relevant design } \\
\text { stage, designers } \\
\text { considered it as } \\
\text { helpful for the } \\
\text { design process }\end{array}$ & $\begin{array}{l}\text { Opposing comment that some } \\
\text { feedback is "actually too detailed" } \\
\text { (interview) [project leader (1) | case II] } \\
\text { Comment "but we will deal with those } \\
\text { [too detailed comments] anyway" } \\
\text { (interview) [project leader (1) | case II] } \\
\text { Comment that the virtual } \\
\text { environment feedback was "helping } \\
\text { [the designer] a lot to understand the } \\
\text { clients well" and "respond well, listen } \\
\text { to them carefully and retort properly" } \\
\text { (interview) and answers to issues } \\
\text { identified in the virtual environment } \\
\text { (observation) [project leader (2) | case } \\
\text { II] } \\
\text { Feedback considered as supportive to } \\
\text { the design process as a whole } \\
\text { (observation) [building information } \\
\text { manager | case I] }\end{array}$ & yes \\
\hline
\end{tabular}

time needed to import design files in a virtual environment and to organize individual design reviews. 


\section{Limitations and future research}

As far as the research limitations concerned, this study dealt with individual cases without reference to a comparison group. We did not try to control for independent variables that account for variations in the observed phenomena. Instead, we chose for in-depth explorations of multiple real-world building design reviews in an attempt to expand and generalize theories (i.e. we aimed for analytical rather than statistical generalization). That approach is most appropriate here, since we dealt with a 'how' question, had little control over the events studied and the focus was on a contemporary phenomenon within a realworld context (Yin, 2009). Flyvbjerg (2006) argues that contextually rich case descriptions (as we aimed to provide here) can be even more valuable as a source of scientific development than predictive theories and universals. An inherent drawback is, however, that we cannot generalize the findings to a wider 'population' (of building design reviews) because we cannot know whether the two cases are 'representative.' This research is thus limited to the generation of preliminary support for a number of hypotheses: additional research is needed to test, refine and extend the theory that we built here. Albeit at the expense of losing the connection with a real-world setting, more experimental research would allow to systematically control for certain variables and could thus identify cause-and-effect relationships at hand.

Deploying the novel virtual reality environment also came with its limitations. The prototypical tool only visualizes geometric design information such as shape, size and location. To take decisions on how to proceed with a design project, clients will, however, also need non-geometric information such as design specifications or maintenance data. As also observed by J. Wang et al. (2014), research (including ours) is rarely concerned with visualizing such information. An additional problem here is that it was time-consuming to organize individual review sessions. Importing the relevant design files and preparing them for use in a virtual environment turned out to be laborious, since 3D design models lack, by nature, information that can be visualized and interacted with in virtual environments (Conniff et al., 2010; Majumdar et al., 2006; Yan et al., 2011). That can be particularly challenging when time pressure is high, as in the second case that was studied. We dealt with this challenge by applying only basic colors and textures to the building objects, which saves time but unavoidably results in rather mediocre graphical quality. This was acceptable here as aesthetics were not yet (case I) and not (case II) a primary design concern, but may be problematic when they are. Future research thus needs to investigate novel approaches for quicker visualization of both geometric and non-geometric design information in virtual reality environments. 
The issue of timing of feedback is another topic worthy of future research. We found that the level of detail of some of the feedback expressed in the virtual environment was inappropriate for the then current design stage. On one hand, some comments in the second case, which dealt with the definitive design stage, seemed too detailed - even though designers considered them as 'helpful.' On the other hand, the comments from the first case seemed more appropriate for the then current draft design stage. That may be explained by the corresponding levels of realism with which these design proposals were represented in their virtual environments: the (more) rough shapes and basic colors of the draft design essentially (better) indicate that the design is not yet finished. This fits with the observation of Conniff et al. $(2010$, p. 432) that "the greater the level of realism, the more obvious [is] the absence of the final ingredients that make an environment actually real." Since realistic design representations apparently elicit more detailed comments, deploying a virtual environment offers opportunities to improve the timing of feedback. To verify whether that feedback does not lead to additional design rework, we propose a (longitudinal) study with multiple implementations of a pre-meeting virtual environment in different design stages of a single project.

Finally, it would be interesting to investigate why clients were more engaged within the review process. We provided an example of a self-identified introvert that, according to the designers, "contributed much more" during the review meeting he attended. On a broader basis it remains, however, unclear why clients would do that: is it because they have pre-identified design concerns that enable their engagement or did they have more confidence in their own knowledge arising from the use of a virtual environment? We speculate that it is a mix of both, but more research is needed to uncover the underlying mechanisms at hand.

\section{Conclusions}

This paper offers in-depth insights into (and recommendations for) supporting design reviews with pre-meeting virtual reality environments. A prototypical virtual environment was developed and implemented in two real-world design projects. Both our theoretical expectations and empirical findings about this are organized into a pattern consisting of three main categories: exploration from a user perspective, participation in solution-finding and feedback on a design proposal. Through systematically attempting to match these patterns with each other, we can draw the following conclusions.

Regarding exploration from a user perspective, we conclude that the theoretical and empirical pattern match: clients using the virtual environment discovered 
(problematic) issues in the design and were able to imagine what the future building would look like in reality.

Regarding participation in solution-finding, we firstly conclude that there is support for the proposition that clients would feel empowered to contribute building the design solution further with their feedback. Secondly, the proposition that clients would actively participate in discussions about design issues they previously identified themselves during their virtual walkthroughs is partly supported with empirical evidence. Thirdly, there is empirical evidence for the proposition that clients who regard themselves as introverted feel comfortable to express feedback.

Regarding feedback on a design proposal, we firstly conclude that the proposition that feedback expressed in the virtual environment would concern a key part of the design and is suited to contribute to a change in that design is partly supported with empirical evidence. Secondly, there is a match for the proposition that designers regard the feedback expressed in the virtual environment as helpful to guide the design process.

Overall, we conclude that theoretical expectations and pragmatic realities regarding the support of pre-meeting virtual reality environments for design review match (yet in varying degrees) in the areas of: exploration from a user perspective, participation in solution-finding and feedback on a design proposal. The insights and recommendations of this paper provide a next stepping stone for fellow scholars and practitioners to further develop and exploit virtual reality environments for architectural and engineering design reviews.

\section{Acknowledgements}

We would like to express our gratitude to the consultancy and engineering firms working on the two design projects mentioned in this study for granting us access to their projects.

\section{References}

Bassanino, M., Fernando, T., \& Wu, K. C. (2014). Can virtual workspaces enhance team communication and collaboration in design review meetings? Architectural Engineering and Design Management, 10(3-4), 200-217.

Bassanino, M., Wu, K. C., Yao, J., Khosrowshahi, F., Fernando, T., \& Skjærbæk, J. (2010). The impact of immersive virtual reality on visualisation for a design review in construction. Paper presented at the Information Visualisation (IV), 2010 14th International Conference. 
Bernard, H. R., \& Ryan, G. W. (2010). Analyzing qualitative data: Systematic approaches. Thousand Oaks, CA: SAGE publications.

Bouchlaghem, D., Shang, H., Whyte, J., \& Ganah, A. (2005). Visualisation in architecture, engineering and construction (AEC). Automation in Construction, 14(3), 287-295.

Bowman, D. A., Koller, D., \& Hodges, L. F. (1997). Travel in immersive virtual environments: An evaluation of viewpoint motion control techniques. Paper presented at the Virtual Reality Annual International Symposium, 1997., IEEE 1997.

Cao, G., Clarke, S., \& Lehaney, B. (2004). The need for a systemic approach to change management-a case study. Systemic Practice and Action Research, 17(2), 103126.

Cárcamo, J. G., Trefftz, H., Acosta, D. A., \& Botero, L. F. (2014). Collaborative design model review tool for the AEC industry. Paper presented at the 2014 Virtual Concept International Workshop, Medellin, Colombia.

Castronovo, F., Nikolic, D., Liu, Y., \& Messner, J. (2013, 30-31 October 2013). An evaluation of immersive virtual reality systems for design reviews. Paper presented at the 13th International Conference on Construction Applications of Virtual Reality, London, UK.

Chionna, F., Cirillo, P., Palmieri, V., \& Bellone, M. (2015). A proposed hardware-software architecture for Virtual Reality in industrial applications Augmented and Virtual Reality (pp. 287-300): Springer.

Conniff, A., Craig, T., Laing, R., \& Galán-Díaz, C. (2010). A comparison of active navigation and passive observation of desktop models of future built environments. Design Studies, 31(5), 419-438.

Cross, N. (2008). Engineering design methods: Strategies for product design. West Sussex, England: John Wiley \& Sons.

Cruz-Neira, C., Leigh, J., Papka, M., Barnes, C., Cohen, S. M., Das, S., ... Sandin, D. J. (1993). Scientists in wonderland: A report on visualization applications in the CAVE virtual reality environment. 59-66.

De Graaf, R. S., \& Dewulf, G. P. M. R. (2010). Applying the lessons of strategic urban planning learned in the developing world to the Netherlands: A case study of three industrial area development projects. Habitat International, 34(4), 471-477.

Derry, S. J. (2007). Guidelines for video research in education. Retrieved from Chicago: http://drdc.uchicago.edu/what/video-research-guidelines.pdf

Dossick, C. S. (2014). Messy work in virtual worlds: exploring discovery and synthesis in virtual teams Cooperative Design, Visualization, and Engineering (pp. 134-142): Springer.

Dossick, C. S., Anderson, A., Iorio, J., Neff, G., \& Taylor, J. (2012). Messy talk and mutual discovery: exploring the necessary conditions for synthesis in virtual teams. Paper presented at the Engineering Project Organizations Conference, Rheden, the Netherlands.

Dunston, P. S., Arns, L. L., Mcglothlin, J. D., Lasker, G. C., \& Kushner, A. G. (2011). An immersive virtual reality mock-up for design review of hospital patient rooms Collaborative design in virtual environments (pp. 167-176): Springer.

Eastman, C., Teicholz, P., Sacks, R., \& Liston, K. (2011). BIM Handbook: a guide to Building Information Modeling. Hoboken: John Wiley \& Sons. 
Flyvbjerg, B. (2006). Five misunderstandings about case-study research. Qualitative Inquiry, 12(2), 219-245.

Følstad, A., Hornbæk, K., \& Ulleberg, P. (2013). Social design feedback: evaluations with users in online ad-hoc groups. Human-centric Computing and Information Sciences, 3(1), 1-27.

Froehlich, M. A., \& Azhar, S. (2016). Investigating virtual reality headset applications in construction. Paper presented at the Proceedings of the 52nd ASC International Conference, Provo, UT.

Garcia, A. C. B., Kunz, J., \& Fischer, M. (2005). Voting on the agenda: the key to social efficient meetings. International Journal of Project Management, 23(1), 17-24.

Germani, M., Mengoni, M., \& Peruzzini, M. (2012). An approach to assessing virtual environments for synchronous and remote collaborative design. Advanced Engineering Informatics, 26(4), 793-813.

Gül, L. F. (2009). Evaluating design behaviour when using emerging collaboration technologies. Architectural Engineering and Design Management, 5(3), 107-123.

Hartmann, T., \& Fischer, M. (2007). Supporting the constructability review with 3D/4D models. Building Research \& Information, 35(1), 70-80.

Iorio, J., \& Taylor, J. E. (2014). Boundary object efficacy: the mediating role of boundary objects on task conflict in global virtual project networks. International Journal of Project Management, 32(1), 7-17.

Iorio, J., Taylor, J. E., \& Dossick, C. S. (2011). A bridge too far: examining the impact of facilitators on information transfer in global project networks. Proceedings Editor.

Jensen, P. A. (2011). Inclusive briefing and user involvement: Case study of a media centre in Denmark. Architectural Engineering and Design Management, 7(1), 38-49.

Jordan, B., \& Henderson, A. (1995). Interaction analysis: Foundations and practice. The journal of the learning sciences, 4(1), 39-103.

Kim, M. J., Wang, X., Love, P., Li, H., \& Kang, S. C. (2013). Virtual reality for the built environment: a critical review of recent advances. Journal of Information Technology in Construction, 18, 279-305.

Koutsabasis, P., Vosinakis, S., Malisova, K., \& Paparounas, N. (2012). On the value of Virtual Worlds for collaborative design. Design Studies, 33(4), 357-390.

Kumar, S., Hedrick, M., Wiacek, C., \& Messner, J. I. (2011). Developing an experiencedbased design review application for healthcare facilities using a 3D game engine. Journal of Information Technology in Construction, 16, 84-103.

Le Dantec, C. A., \& Do, E. Y. L. (2009). The mechanisms of value transfer in design meetings. Design Studies, 30(2), 119-137.

Li, H., Huang, T., Kong, C. W., Guo, H. L., Baldwin, A., Chan, N., \& Wong, J. (2008). Integrating design and construction through virtual prototyping. Automation in Construction, 17(8), 915-922.

Majumdar, T., Fischer, M. A., \& Schwegler, B. (2006). Conceptual design review with a virtual reality mock-up model. Paper presented at the Building on IT: joint international conference on computing and decision making in civil and building engineering. Montreal, Canada: American Society of Civil Engineers. 
Merrick, K. E., Gu, N., \& Wang, X. (2011). Case studies using multiuser virtual worlds as an innovative platform for collaborative design: ITcon.

Mobach, M. P. (2008). Do virtual worlds create better real worlds? Virtual Reality, 12(3), 163-179.

Oak, A. (2011). What can talk tell us about design?: Analyzing conversation to understand practice. Design Studies, 32(3), 211-234.

Paton, B., \& Dorst, K. (2011). Briefing and reframing: A situated practice. Design Studies, 32(6), 573-587.

Rosenman, M. A., Smith, G., Maher, M. L., Ding, L., \& Marchant, D. (2007). Multidisciplinary collaborative design in virtual environments. Automation in Construction, 16(1), 37-44.

Roussos, M., Johnson, A., Moher, T., Leigh, J., Vasilakis, C., \& Barnes, C. (1999). Learning and building together in an immersive virtual world. Presence: Teleoperators and Virtual Environments, 8(3), 247-263.

Rwamamara, R., Norberg, H., Olofsson, T., \& Lagerqvist, O. (2010). Using visualization technologies for design and planning of a healthy construction workplace. Construction Innovation, 10(3), 248-266.

Sacks, R., Perlman, A., \& Barak, R. (2013). Construction safety training using immersive virtual reality. Construction Management and Economics, 31(9), 1005-1017.

Salter, A., \& Torbett, R. (2003). Innovation and performance in engineering design. Construction Management and Economics, 21(6), 573-580.

Sampaio, A. Z., \& Martins, O. P. (2014). The application of virtual reality technology in the construction of bridge: The cantilever and incremental launching methods. Automation in Construction, 37, 58-67.

Shen, W., Shen, Q., \& Sun, Q. (2012). Building Information Modeling-based user activity simulation and evaluation method for improving designer-user communications. Automation in Construction, 21(0), 148-160.

Shen, W., Zhang, X., Shen, G. Q., \& Fernando, T. (2013). The user pre-occupancy evaluation method in designer-client communication in early design stage: A case study. Automation in Construction, 32, 112-124.

Shiratuddin, M. F., \& Thabet, W. (2007). Information rich Virtual Environment (VE) design review. Paper presented at the 24th W78 Conference \& 5th ITCEDU Workshop \& 14ht EG-ICE Workshop, Maribor, Slovenia.

Shiratuddin, M. F., \& Thabet, W. (2011). Utilizing a 3D game engine to develop a virtual design review system. Journal of Information Technology in Construction, 16, 3968.

Thyssen, M. H., Emmitt, S., Bonke, S., \& Kirk-Christoffersen, A. (2010). Facilitating client value creation in the conceptual design phase of construction projects: A workshop approach. Architectural Engineering and Design Management, 6(1), 18-30.

Trochim, W. M. K. (1989). Outcome pattern matching and program theory. Evaluation and program planning, 12(4), 355-366.

Wang, J., Wang, X., Shou, W., \& Xu, B. (2014). Integrating BIM and augmented reality for interactive architectural visualisation. Construction Innovation, 14(4), 453-476.

Whyte, J. (2002). Virtual Reality and the built environment. Oxford: Elsevier Science. 
Woksepp, S., \& Olofsson, T. (2006). Using virtual reality in a large-scale industry project. Journal of Information Technology in Construction, 11(43), 627-640.

Woksepp, S., \& Olofsson, T. (2008). Credibility and applicability of virtual reality models in design and construction. Advanced Engineering Informatics, 22(4), 520-528.

Yan, W., Culp, C., \& Graf, R. (2011). Integrating BIM and gaming for real-time interactive architectural visualization. Automation in Construction, 20(4), 446-458.

Yin, R. K. (2009). Case Study Research: Design and Methods (4 ed.). Thousand Oaks: Sage. 


\section{Chapter 6}

\section{Experiencing supply chain optimizations:}

\section{A serious gaming approach}

Marc van den Berg, Hans Voordijk, Arjen Adriaanse \& Timo Hartmann

Published

Van den Berg, M., Voordijk, H., Adriaanse, A., \& Hartmann, T. (2017). Experiencing supply chain optimizations: A serious gaming approach. Journal of Construction Engineering and Management, 143(11), 1-14. 


\begin{abstract}
To provide new opportunities for acquiring experience in coordinating construction supply chain activities, this paper describes a serious gaming approach. Serious games offer their users an experience that is designed to be meaningful. Following the Triadic Game Design approach, the authors designed a board game that challenges a player to design and construct a skyscraper called Tower of Infinity. The research aim was to explore how serious games (like this one) can contribute to the experiential acquisition of construction supply chain management knowledge. Game sessions were organized in which 64 construction management students played the board game and reflected on it in a written report. A content analysis of these reports was then conducted to assess three hypotheses. Based on that analysis, it is concluded that serious games can enable students to experientially learn how to improve the performance of a construction supply chain through: (1) coordinating design and construction tasks in a coherent manner; (2) taking constructability aspects into account when designing; and (3) continuously balancing scope, time, and cost throughout a project. Experiencing supply chain optimizations in such a playful way promotes better understanding of how and why waste occurs and may, ultimately, contribute to more efficient construction supply chain management practices.
\end{abstract}

Keywords: Project planning and design; Experiential learning; Serious game; Supply chain management; Waste 


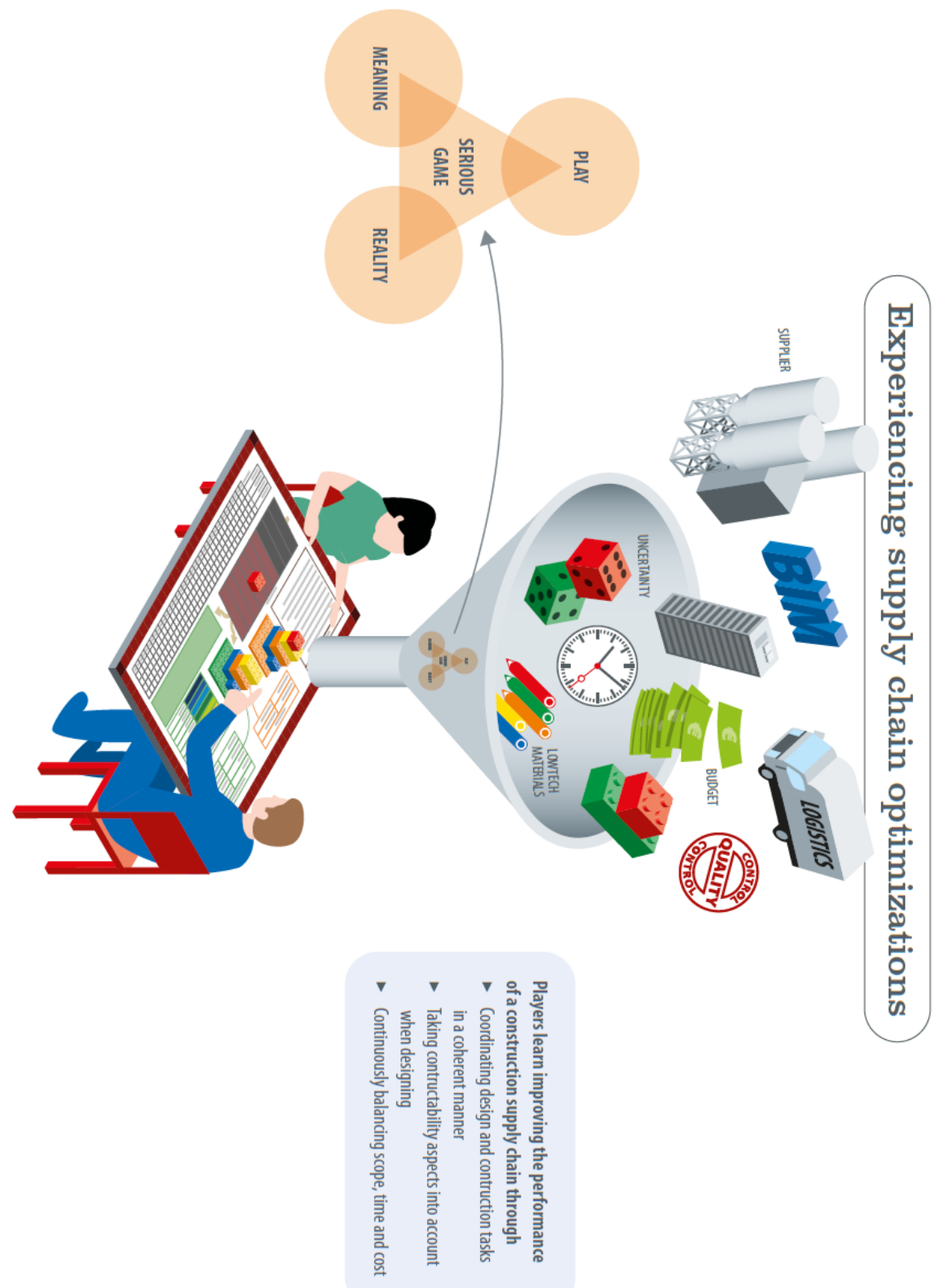

Abstract | 149 


\section{Introduction}

To provide new opportunities for acquiring an intuitive understanding how and why waste occurs in construction supply chains, this paper describes a serious gaming approach. Supply chain management in construction has been defined as "the network of facilities and activities that provide customer and economic value to the functions of design development, contract management, service and material procurement, materials manufacture and delivery, and facilities management" (Love, Irani, \& Edwards, 2004). Numerous researchers have claimed that the construction industry is lagging behind in terms of supply chain practices and efficiency (Bankvall, Bygballe, Dubois, \& Jahre, 2010; Segerstedt \& Olofsson, 2010). Even in normal situations construction supply chains have a large quantity of problems and waste (Vrijhoef \& Koskela, 2000). That waste may manifest itself in waiting time for crews, rework, unnecessary movement and handling of materials, unused inventories of workspaces and of materials, etc. (Sacks, Radosavljevic, \& Barak, 2010). Explanations are sought in the lack of coordination and communication between parties, adversarial contractual relationships, lack of customer-supplier focus, price-based selection and ineffective use of technology (Love et al., 2004). Most scholars have, however, ignored one trivial factor: it is hard for construction professionals to gain handson experience in coordinating supply chain activities.

Practically applicable knowledge about how to improve the performance of a construction supply chain is difficult to acquire. Bak and Boulocher-Passet (2013) argue that delivering supply chain education that is important and relevant for the industry is a major challenge. Besides introducing theoretical models and concepts, university educators typically rely on practical assignments and/or stories of best practices to enable students to learn. Both of these approaches are problematic. Educational assignments usually ignore many of the peculiarities found in real-world construction projects, such as uncertainty, urgency, ambiguity and uniqueness (Winch, 2010). Similarly, stories of best practices cannot provide the thick context that is necessary to understand how practitioners in the past successfully applied a certain tool or method. Peterson, Hartmann, Fruchter, and Fischer (2011) argue that these two common approaches often fall short because they neglect the complexity of the multiple intertwined factors found in practice. Rojas and Mukherjee (2005) also maintain that traditional teaching methods are not fully capable of conveying how theoretical concepts can be applied to construction practice. Likewise, studies in the area of safety and hazard recognition have illustrated that poorly designed, ineffective and unengaging methods significantly impede teaching/training efforts (Albert, Hallowell, Kleiner, Chen, \& Golparvar-Fard, 2014; Namian, Albert, Zuluaga, \& Behm, 2016). The consequence of these problems is that graduate 
students are poorly prepared for dealing with real-world supply chain management problems and need to learn on the job.

One seemingly promising way for dealing with this problem is to deploy serious games that enable learning about construction supply chain management. A game is defined as "a problem-solving activity, approached with a playful attitude" (Schell, 2008). The "serious" adjective is generally used to refer to a subset of "(digital) games that contribute to the achievement of a defined purpose other than mere entertainment" (Susi, Johannesson, \& Backlund, 2007). These types of games playfully visualize and simulate real-world events or processes in an environment that resembles realistic work situations. They can bring important theoretical topics to life, providing means to understand and practice essential educational issues (Battini, Faccio, Persona, \& Sgarbossa, 2009). Serious games therefore integrate elements like rules, goals, challenges and performance indicators in an interactive environment. Players learn from meaning-making of the experience that the game provides them, which is referred to as experiential learning (Kolb, 1984). The aim of the presented research is to explore how serious games can contribute to experiential learning about construction supply chain management.

This paper is structured as follows. The next section provides the argument that it is unclear how players may learn from experiences that serious games for construction supply chain management offer them. We then illustrate how we designed such a game ourselves. The primary focus of this study is nevertheless on exploring how that game contributes to experiential learning. To that end, it is described how data was collected and analyzed within the context of a university class. The results reveal how the game enabled graduate students to optimize construction supply chains. This is followed by a discussion how these results should be interpreted and concluded with the argument that experiencing supply chain optimizations in a playful way helps to better understand how and why waste occurs.

\section{Theoretical framework}

The theoretical foundation for serious games can be found in the experiential learning theory. This theory emphasizes the central role that experience plays in the learning process (Hussein, 2015). Experiential learning theory defines learning as "the process whereby knowledge is created through the transformation of experience" (Kolb, 1984, p. 38). Knowledge results from the combination of grasping and transforming experience. This process is commonly represented as a four-stage cycle that continues endlessly. It starts with a "concrete experience" after which learners have observations and need time to reflect on these 
("reflective observation"). By doing so, abstract concepts and generalizations are made ("abstract concepts"). These can then be used as an input for experimentation to test whether the newly formed ideas hold true ("abstractive experimentation"). That leads to a new concrete experience, with which a new cycle starts (Harteveld, 2011). The term experiential is therefore used to differentiate the theory from cognitive learning theories, which emphasize cognition over affect, and behavioral learning theories, which deny any role for subjective experience in the learning process (Kolb, Boyatzis, \& Mainemelis, 2001).

Serious games allow people to experience situations that are impractical or impossible in the real world for reasons of cost, time or safety. These types of games offer experimental environments within which learning can occur and be observed (Hussein, 2015). Serious games are "experiential" by nature: they are about doing and as such give an experience to the user. That experience is designed to be meaningful (Susi et al., 2007). Several studies have reported that serious games have positive effects on knowledge acquisition, motivation and engagement (Bellotti, Kapralos, Lee, Moreno-Ger, \& Berta, 2013; Connolly, Boyle, MacArthur, Hainey, \& Boyle, 2012). Other benefits are that they may increase the verisimilitude of the teaching material and allow students to work at their own pace (Al-Jibouri \& Mawdesley, 2001). Serious games may augment traditional teaching methods (Hegazy, Abdel-Monem, Saad, \& Rashedi, 2013) or be the only possible means of practicing real-world problems such as for military operations or surgery techniques (Bellotti et al., 2013; Connolly et al., 2012). They do this by mimicking and simplifying the real world in a risk-free environment that encourages exploration and trial-and-error actions and with the possibility of instant feedback (Mawdesley, Long, Al-jibouri, \& Scott, 2011). In that regard, a serious game differs from a simulation model, defined as just a "representation of reality [of] some known process/phenomenon," in that the latter is typically more accurate but lacks playful, motivational and/or goal-oriented activities (Deshpande \& Huang, 2009). Such closely related simulation models have been developed for (among others) interorganizational decision-making (Xue, Li, Shen, \& Wang, 2005), real-time information sharing (Min \& Bjornsson, 2008), inventory-production-transportation systems (Long \& Zhang, 2014), workforce management (Watkins, Mukherjee, Onder, \& Mattila, 2009) and the evolution of collaboration (Son \& Rojas, 2011).

Serious games have a long-standing history in supply chain management education. To introduce management participants to the concept of economic dynamics, Sterman (1989) used a participative simulation model of a beer distribution system, which later became known as the 'MIT Beer Game'. This game is particularly powerful in demonstrating the 'bullwhip effect' that causes 
high variability in order and inventory levels when several participants in the same supply chain attempt to anticipate the future demand of their immediate client. However, the game is also criticized for its limited functionalities and for being based on an unrealistic supply chain model (Deshpande \& Huang, 2009; Holweg \& Bicheno, 2002). In the aftermath of this game, many other supply chain management games have been developed. Examples include the 'Lean Leap Logistics Game' that deals with production and ordering within a steel manufacturing environment (Holweg \& Bicheno, 2002), the 'Supply Chain Management Trading Agent Competition' that revolves around a pc assembly supply chain consisting of a number of competing manufacturers, component suppliers and customers (Arunachalam \& Sadeh, 2005), the 'Distributor Game' that simulates complexities of a global supply chain with physically separated distributors (Corsi et al., 2006), the 'Poker Chip Game' that illustrates the impacts of push versus pull inventory policies (Cox III \& Walker, 2006) and the 'Supply Chain Puzzle Game' that addresses various design and behavioral issues in supply chain collaboration (Fawcett \& McCarter, 2008). Despite their educational value, none of these serious games deals with peculiarities for the construction industry, like site production, one-of-a-kind products, temporary organizations and the relation between design and production.

Numerous other serious games have been used that deal with such construction peculiarities. The 'Parade Game', for example, illustrates the impact variability has on work flow in a single-line production system (Tommelein, Riley, \& Howell, 1999) and the 'Technion Lean Apartment Construction Simulation Game' (LEAPCON) simulates the execution of interior finishing activities required for construction of a high-rise building (Sacks, Esquenazi, \& Goldin, 2007). The 'Virtual Coach' represents a multiyear project of a situational simulation environment for construction management education (Dossick, Mukherjee, Rojas, \& Tebo, 2010; Rojas \& Mukherjee, 2005). It challenges players to respond to events like material shortages, low productivity or incomplete designs by making decisions that impact the project outcome. Other games for construction management are the 'Muck' and the 'Canal game' that focus on project planning and control (Al-Jibouri \& Mawdesley, 2001; Mawdesley et al., 2011), 'Construction Contracts in a Competitive Market' $\left(\mathrm{C}^{3} \mathrm{M}\right)$ that introduces the principles of competitive bidding (Nassar, 2003), the 'C-Negotiation Game' for construction procurement and negotiation (Dzeng \& Wang, 2017) and 'The Expansive Hospital' that lets players learn the value of boundary crossing in design projects (Van Amstel, Zerjav, Hartmann, Dewulf, \& Van der Voort, 2016). Furthermore, Tsai and Chi (2015) reported on three games for conflict management. Although these serious games cover aspects that are unique to the construction industry, they do not deal with coordinating supply chains in a holistic fashion. 
There are two additional problems with the experiences that most of these serious games provide. An important assumption of serious games is that players can transfer the game experience to the real world. This raises the first question whether these experiences are designed in a systematic (using established principles, procedures and theories of designing games) and well-balanced (aiming to be valid, meaningful and entertaining at the same time) manner. Most of the aforementioned studies describe a game design as an object in detail, but they share little about game design as a process. This makes it unclear how and why certain game design choices were made. One exception is the study of Rüppel and Schatz (2011) that, based on the Triadic Game Design approach of Harteveld (2011), carefully elaborates on design considerations of a serious game for fire safety evacuation simulations. A second question is whether players indeed acquire the experience that was planned when designing that serious game. To that end, multiple literature reviews concluded that many studies lack a rigorous assessment (Bellotti et al., 2013; Chin, Dukes, \& Gamson, 2009; Mikropoulos \& Natsis, 2011). Generally, data can be used to demonstrate that stated learning goals are actually being met at either the end of the learning process (summative assessment) or throughout the process (formative assessment). The most common post-assessment method is a simple survey, which has as a disadvantage that it relies on the opinions of the player and does not depend on all the information that can be collected regarding what happened within the game (Bellotti et al., 2013). In-game assessment that examines how and why a player applied certain strategies is used scarcely, even though particularly digital games have the advantage of keeping track of every move and decision a player makes. Due to these problems, the potential of those serious games to contribute to experiential learning remains thus unclear.

In summary, previous studies on serious games have not dealt with the peculiarities of the construction industry for supply chain management, did not systematically design a game or lack rigorous reflections. It thus remains unclear how players may learn from experiences that a serious game for construction supply chain management provides them.

\section{Design of a serious game}

The authors therefore studied the use of a low-tech serious game called 'Tower of Infinity' that was systematically designed by the first-mentioned author. Tower of Infinity is a one-player board game that uses LEGO bricks to simulate an integrated (Design \& Construct) project (Figure 11). It puts players in the role of main contractor and, as such, lets them assign their available crews to modeling, ordering and assembling tasks in order to satisfy client requirements and make 
a profit. This game came about by following the Triadic Game Design (TGD) approach by Harteveld (2011). That approach provides an overall 'way of thinking' for designing a serious game. The core idea is that a good serious game balances the three interdependent 'worlds' of Reality, Meaning and Play. These three worlds shed light on a game in different ways. Each of the worlds is inhabited by different people, disciplines, aspects and criteria (which is why they are called 'worlds'). They are all equally important and thus need to be balanced to create a single whole: a game capable of achieving its serious purpose. To reach an optimum balance, the three worlds should be considered at the same time within critical parts of the game design process (concurrent design) and a repeated cycle of (1) prototyping, (2) testing and evaluating, and (3) redesigning continues until the requirements of the three worlds are met (iterative design). Notwithstanding that iterative nature, we elaborate on these three main steps of the design process here.

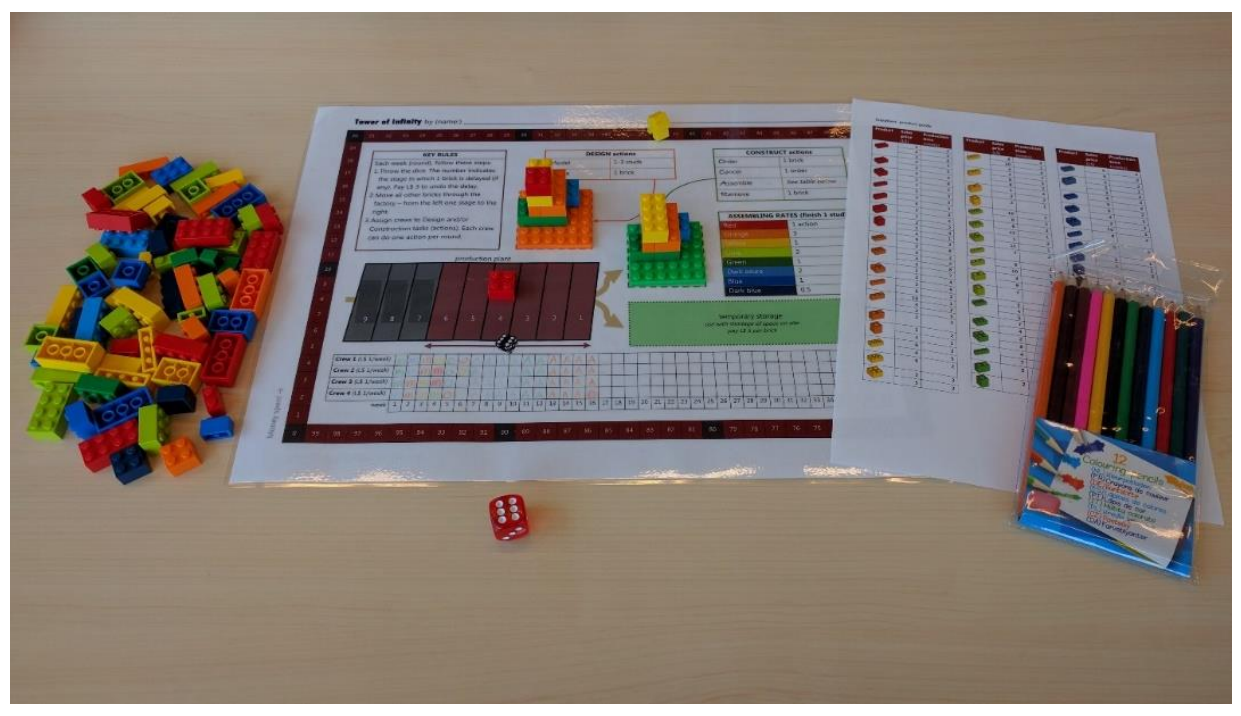

Figure 11: Overview of the serious game 'Tower of Infinity' with LEGO bricks, a play board, dice, a product guide and pencils

\section{Step 1 - Prototyping: integrating worlds of Reality, Meaning and Play}

The authors started the serious game's design process with considering the inhabitants of the three worlds of Reality, Meaning and Play and by attempting to integrate them in a fully working prototype. Figure 12 adopts the Triadic Game Design theory of Harteveld (2011) to represent the inhabitants graphically. 


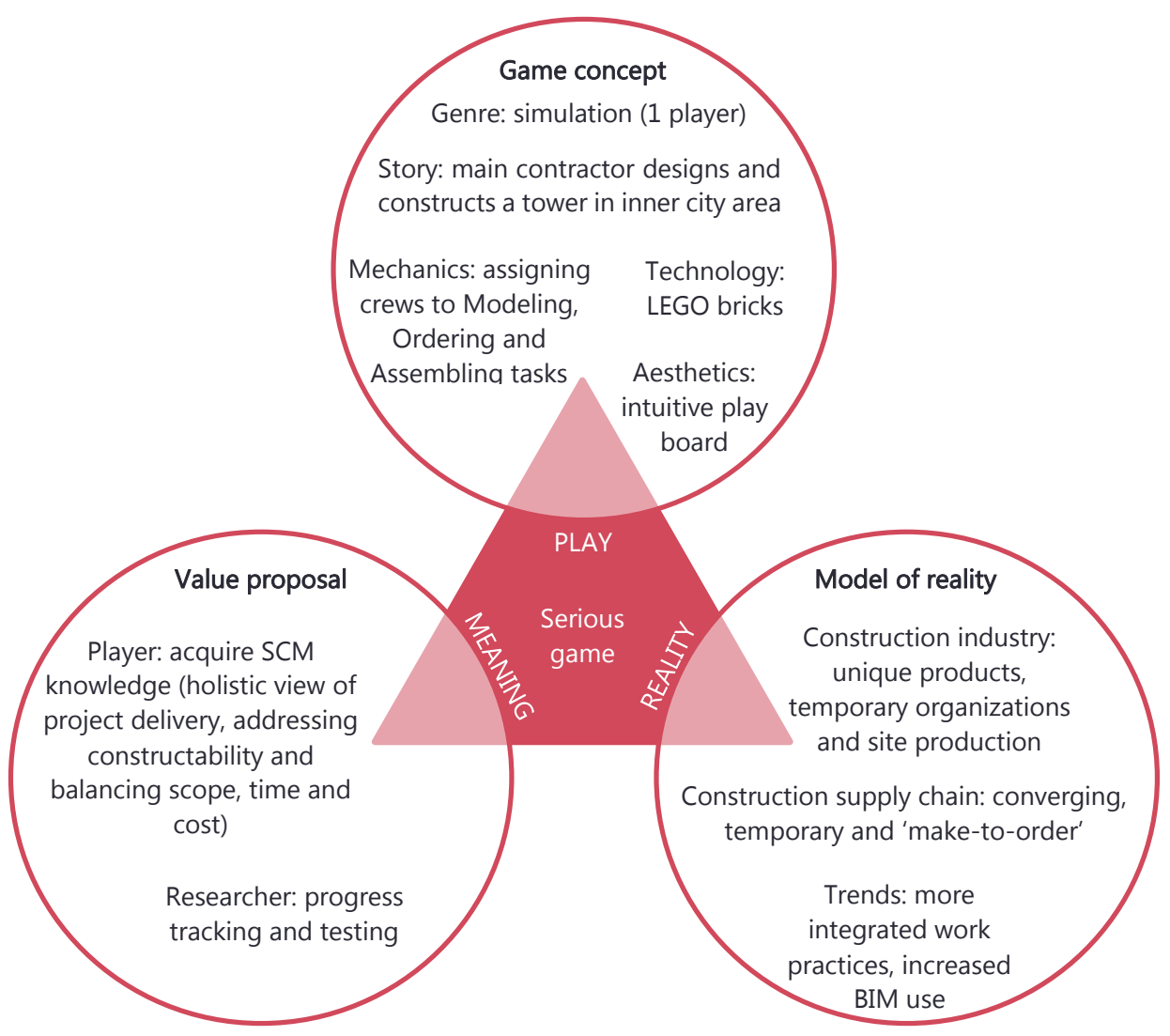

Figure 12: Design of a serious game for construction supply chain management, based on the Triadic Game Design approach of Harteveld (2011)

\section{World of Reality}

The world of Reality considers the game's connection to the physical world. It includes domain-specific knowledge to make a game experience intuitive and understandable. The type of game and its purpose determine how elaborate, realistic and valid the game represents (parts of) reality. It should thereby be noted that reality is interpreted, constructed and translated into a game model. This game model describes the content, boundaries and interrelationships of a game (Harteveld, 2011). Others may well achieve a different model due to differences in scope, information sources, design choices etc.

Construction projects constitute steps to design, manufacture and assemble a product to a customer. The principal construction company that manages a project typically relies heavily on subcontractors and suppliers of building 
materials to execute that project. The great part, about $75 \%$ of the product's value, is built with materials and services purchased from subcontractors and suppliers (Dubois \& Gadde, 2000). This is incorporated in the serious game with a setting in which the player (as main contractor) needs to purchase building materials from suppliers by performing the following steps: choosing a product from a supplier's product guide (containing options with different costs and leadtimes for the same product), picking the raw material from a market/pool of raw materials (that is shared with other players) and placing it in the relevant production stage of a supplier's plant (conform the lead-time as promised in the product guide).

Supply chain management in these project delivery settings generally consists short-lived supply chains that must be established rapidly and remain flexible to match demands that vary over the course of project execution (Tommelein, Ballard, \& Kaminsky, 2008). Supply chains feature dynamics, uncertainty and partial information sharing (Long \& Zhang, 2014). Construction supply chains differ from manufacturing supply chains in that the construction supply chain is typically converging (with materials being clustered and transported to a single construction site rather than going through a factory), temporary (producing one-off projects through duplicated reconfigurations of project organizations) and a representative of a "make-to-order" process (where production only starts after an order is received) (Vrijhoef \& Koskela, 2000). The game represents this with an empty construction site of limited size to which purchased materials are transported after their manufacturing is completed. Materials are only being manufactured after the player places an order (see above).

In recent years, several major trends in the construction industry have been reported that were represented in the serious game as well. As such, the industry has been moving towards more integrated work practices with clients shifting responsibilities to main contractors (Bemelmans, Voordijk, \& Vos, 2012). Integrated contracts like Design \& Construct, in which the main contractor is also responsible for the design (besides the construction), are getting increasingly common. Multi-skilled crews, that can perform a variety of construction-related tasks, are being recognized as a key factor to achieve stable, predictable production (Sacks \& Goldin, 2007). Construction companies are making more and more use of building information modeling (BIM) tools, which enable the creation of a virtual prototype of a complete building before it is actually being built (Eastman et al., 2011; Hartmann et al., 2012). Finally, environmental awareness is increasing, with the construction industry starting to realize that virgin resources are limited (Kourmpanis et al., 2008). The serious game addresses these aspects by putting the player in control of both the design and construction project stages and by offering four crews that can all perform 
several kinds of actions. The availability of (raw) materials used for manufacturing is limited. A three-dimensional prototype needs to be 'modeled' before any materials can be ordered, manufactured and, eventually, assembled.

\section{World of Meaning}

The world of Meaning involves the types of value to be achieved by a game. This considers the meaningful effect beyond the game experience itself. This value proposal is an extensive description how a game will impact the real world (Harteveld, 2011). The values to be achieved can be subdivided in values for the player and values for the researchers/observers.

The player should be able to acquire an intuitive understanding about optimizing project activities regardless of functional or corporate boundaries. Supply chain management theories adopt a holistic and systematic view of project delivery. Traditionally, construction supply chains have had a large quantity of waste and problems, which are mostly caused in another phase than when detected (Vrijhoef \& Koskela, 2000). Examples are errors in the design that are discovered when the actual building is being assembled at the site. In supply chain management, project processes and activities are controlled in an integrated fashion (Tommelein et al., 2008). This is embodied in the philosophy of 'lean construction', which refers to a production system that aims to minimize waste of materials, time and effort in order to generate the maximum possible amount of value (Koskela, 1992; Koskela, Howell, Ballard, \& Tommelein, 2002). Being aware of the importance of production flow, or the sequence of supply chain activities, has a great impact on the effect of variations and is suggested as one approach to reduce waste (Lindhard, 2014). Furthermore, waste can be reduced by explicitly addressing constructability: the capability of a design to be constructed. Projects where construction constraints and possibilities have specifically been addressed can achieve significant cost savings (Koskela, 1992). To achieve system-wide advantages of production it is, finally, necessary to understand how the scope, time and cost relate to each other (Peterson et al., 2011; Tommelein et al., 2008; Xue et al., 2005). Overall, we specified as learning objectives that players need to be able to understand how supply chain optimizations can be achieved through: (1) coordinating design and construction tasks coherently; (2) taking constructability aspects into account when designing and (3) continuously balancing scope, time and cost.

Other values are more valuable for the researchers/observers. Serious games can provide possibilities for assessment, data collection, exploration and theory testing (Harteveld, 2011). Assessment focuses on learning from the perspective 
of the player and aims to demonstrate that stated goals and objectives are actually being met (Chin et al., 2009). Games must therefore "provide some means of testing and progress tracking and the testing must be recognizable within the context of education or training they are attempting to impart" (Bellotti et al., 2013). When games allow for any changes in some aspects or when researchers can adjust variables, it is possible to conduct explorations or to test theories. Here, the game includes a set of pencils with different colors that players need to use for writing down all their actions in a project schedule.

\section{World of Play}

The world of Play deals with the goals and rules of a game. Games are highly interactive and engaging tools that immerse people into a fictive situation. Clear goals and rules differentiate games from simulations and other types of playful activities. To develop a game, designers need to come up with a game concept: a detailed idea of what the game is like (Harteveld, 2011). Seven genres are conceived: action, adventure, puzzle, role-playing, simulation, strategy and virtual world games.

The concept of the supply chain management game belongs to the simulation games as we were interested in modeling actual processes and situations. According to Harteveld (2011), such games are characterized by a closer connection to reality, the lack of an extensive story that evolves as the player progresses and many degrees of freedom and openness. Here, the motivation for making the game was to offer the player an idea how it would be to coordinate a construction supply chain. As a guiding principle, emphasis was thereby given to the "peculiar relation between design and production" found in the construction industry (Segerstedt \& Olofsson, 2010, p. 348). We elaborated this general game idea by defining the four basic elements that are, according to Schell (2008), part of every game: its mechanics, story, aesthetics and technology. The game simulates a Design \& Construct project in which a player takes the role of a main contractor and can perform a limited number of actions per week/round (mechanics). Actions include modeling, ordering and assembling. These are performed by crews, which are multi-skilled and thus capable of performing each of these actions. Creativity is needed to come up with a design proposal that meets the requirements and can actually be built. The game takes place after the player is awarded a contract of designing and constructing a highrise building in an inner city area (story). The player starts with a list of client requirements and is then challenged to complete the project for a fixed price and within a certain time. These requirements need to provide much freedom to enable experimenting with different problem-solving strategies. The layout of 
the serious game needs to support the player's game play through indicating important rules, variables and parameters (aesthetics). A board game that makes use of low-tech materials was considered most appropriate to support this type of play (technology). LEGO bricks were selected as the main materials in the game because their standardized interfaces allow for rapid prototyping, simulations and visualizations (Kristiansen \& Rasmussen, 2014). The game tasks and objectives were then related to these bricks, their sizes and colors.

Step 2 - Testing and evaluating: play-testing prototypical serious game in workshop

The following step in the design process of the serious game was to test and evaluate a prototypical version that attempted to integrate the worlds of Reality, Meaning and Play. That prototypical version can be described as a board game in which the player takes on the role of a main contractor responsible for designing and constructing the Tower of Infinity: a multifunctional skyscraper located in an inner city area. Each player has her/his own set of LEGO bricks meant for designing (modeling) and a group of players together shares a (larger) set of LEGO bricks meant for constructing (ordering and assembling). Players use these bricks to create two towers, one representing the building information model and one representing the actual tower. Playing cards with constructionrelated risks were, in combination with a dice, included to simulate project uncertainties (but in a later version the cards were removed). Four multi-skilled crews were available to a player that could all perform one action/task in a round/week. As conceptualized in Figure 13, these crews could be assigned to any of the next design or construction tasks:

- Model: placing a Design-brick on the plane that represents the BIM software. Bricks can only be modeled when the modeling of any underlying bricks is finished.

- Order: choosing a Construct-brick from a number of available options (displayed in a product guide) and placing it on the conveyor belt of the supplier for manufacturing. Bricks can only be ordered when that part of the design is finished.

- Assemble: placing a Construct-brick on the plane that represents the construction site. Bricks can only be assembled after they have been transported from the supplier to the construction site and after the assembling of any underlying bricks is finished (storage on site is thereby only possible if there is enough space).

To assign a crew to any of these tasks, a player writes down the action in a schedule - using pencils in different colors. For example, for modeling (part of) a 160 | Experiencing supply chain optimizations: A serious gaming approach 


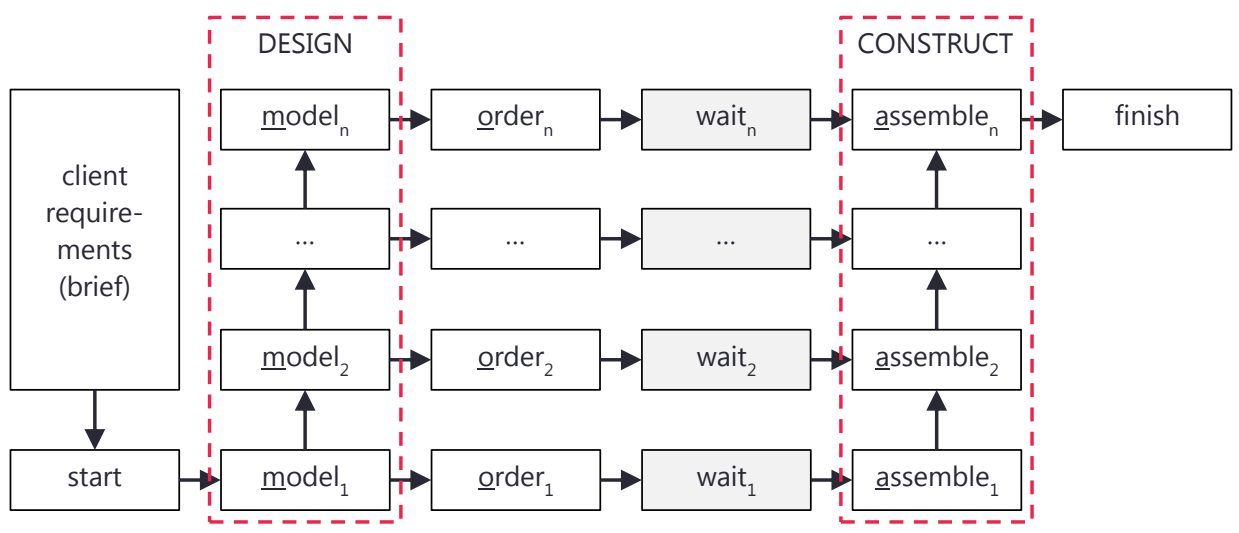

Figure 13: Conceptual model of a serious game for construction supply chain management 'Tower of Infinity' with the in-game actions and their interdependent relations

red brick, the player needs to write down a red ' $M$ ', while for assembling (part of) a yellow one, the player writes down a yellow ' $A$ '. The schedule remains empty if no actions are possible in a certain round, such as when the player needs to wait for a brick to arrive at the construction site. The schedule can thus be used to keep track of a player's actions, which is useful for the player (to decide what to do next) and for the researchers (to analyze the player's in-game strategy).

An extensive play-testing workshop was conducted to verify whether the Triadic Game Design worlds were well-balanced in this prototypical version of the game. This workshop was attended by an international group of 22 construction management educators from Egypt, Sweden, the United Kingdom and the Netherlands. After a short briefing, these educators all played the prototypical game simultaneously. They were then asked to write down their individual feedback on the game, organized by the three worlds of Reality ('what do you think of the way in which the game represents real-world construction management problems?'), Meaning ('what do you think of the value (meaningfulness) of the game for construction education?') and Play ('what do you think of the game concept (goals and rules)?'). The workshop concluded with a structured group discussion on the game design. Table 16 summarizes their feedback: the initial game concept was found interesting and valuable as it offered an understanding of coordination issues within construction supply chains. However, the playing cards with construction-related risks were considered somewhat unrealistic, as was the absence of specific, detailed client requirements. The educators also criticized the game rules as being rather hard to understand. 
Table 16: Summary of the output of a workshop with construction management educators from Egypt, Sweden, the United Kingdom and the Netherlands to assess the balance between the worlds of Reality, Meaning and Play as in a prototypical version of the serious game $(n=22)$

\begin{tabular}{|c|c|c|c|}
\hline Source & Reality & Meaning & Play \\
\hline $\begin{array}{l}\text { Group } \\
\text { discussion }\end{array}$ & $\begin{array}{l}\text { Represents practice to } \\
\text { some extent } \\
\text { All risk probabilities are } \\
\text { the same, which is } \\
\text { unrealistic } \\
\text { Client requirements are } \\
\text { not specific enough } \\
\text { Most realistic are the } \\
\text { concepts of lean } \\
\text { construction, supply } \\
\text { chains and time } \\
\text { scheduling }\end{array}$ & $\begin{array}{l}\text { Provides a proper } \\
\text { understanding of } \\
\text { coordination issues } \\
\text { Helps understanding } \\
\text { many concepts in } \\
\text { construction (supply } \\
\text { chain) management, } \\
\text { such as the importance } \\
\text { of long-term planning } \\
\text { and the allocation of } \\
\text { resources }\end{array}$ & $\begin{array}{l}\text { Good concept, serves its } \\
\text { purpose } \\
\text { Interesting and lots of } \\
\text { fun } \\
\text { Rather difficult: more } \\
\text { instructions are needed }\end{array}$ \\
\hline $\begin{array}{l}\text { Individual } \\
\text { feedback }\end{array}$ & $\begin{array}{l}\text { Simplified, but realistic } \\
\text { and applicable to } \\
\text { practice } \\
\text { Construction constraints } \\
\text { are realistic } \\
\text { The probabilities related } \\
\text { to the risk events are } \\
\text { unrealistic (all the same) } \\
\text { The game ignores some } \\
\text { other problems that are } \\
\text { difficult to implement in } \\
\text { games } \\
\text { Uncertainty (dice) is very } \\
\text { realistic } \\
\text { Making cost-time trade- } \\
\text { offs is realistic and very } \\
\text { interesting }\end{array}$ & $\begin{array}{l}\text { Great introduction to } \\
\text { dependencies between } \\
\text { design, procurement and } \\
\text { construction } \\
\text { Useful to get an } \\
\text { understanding how hard } \\
\text { coordination issues are } \\
\text { in the real world } \\
\text { Fantastic way to make } \\
\text { construction science } \\
\text { easier to imagine } \\
\text { Very useful for } \\
\text { education, particularly to } \\
\text { introduce certain topics }\end{array}$ & $\begin{array}{l}\text { Very good concept: } \\
\text { player (student) feels the } \\
\text { true process } \\
\text { complications and gets } \\
\text { the sense of how to sort } \\
\text { it out } \\
\text { The rules support } \\
\text { learning outcomes } \\
\text { The game needs some } \\
\text { time to understand: } \\
\text { more instructions are } \\
\text { needed } \\
\text { Goals should be clearer } \\
\text { (maximum time, cost, } \\
\text { etc.) } \\
\text { Holistic but not very } \\
\text { simple game }\end{array}$ \\
\hline
\end{tabular}

\section{Step 3 - Redesigning: incorporating feedback into final serious game version}

The last step in the design process of the serious game was to adapt the serious game based on the feedback on the prototypical version. To establish an optimum balance between the three worlds of Reality, Meaning and Play, the authors made a number of changes to the version that had been played by the international group of construction management educators. Figure 14 represents 


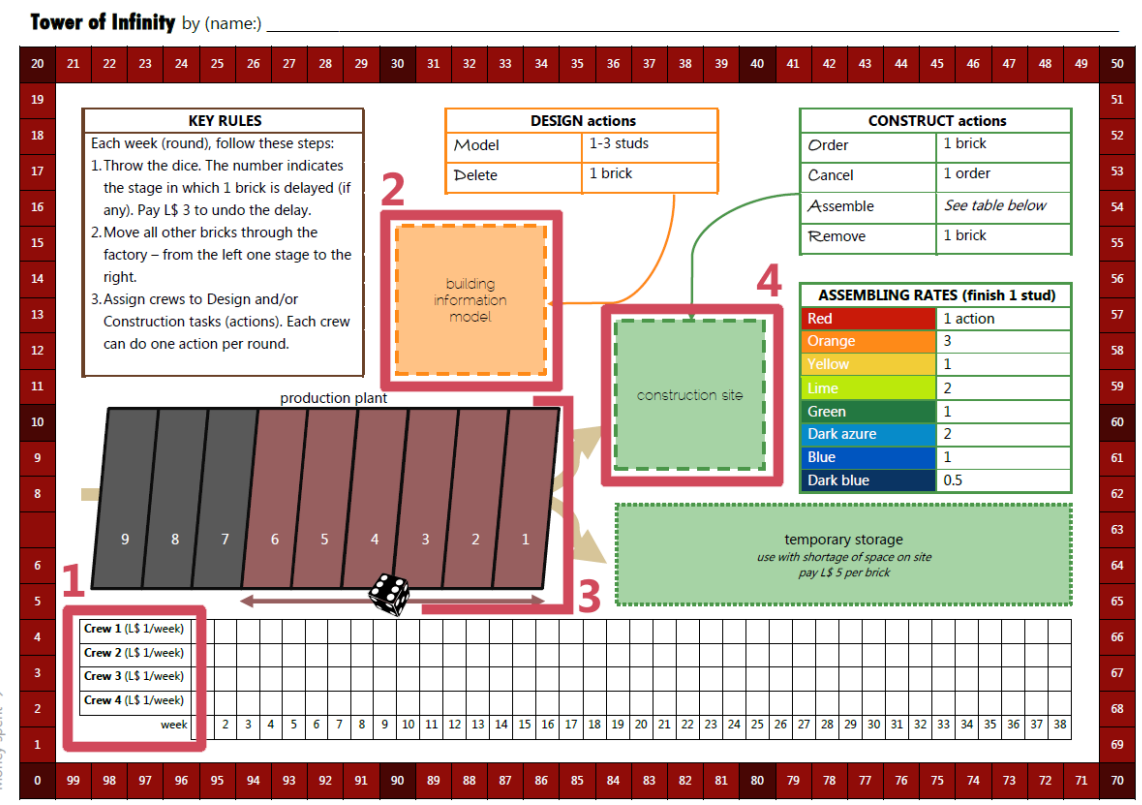

Figure 14: Layout of the board game 'Tower of Infinity': multi-skilled crews (1) can perform design actions using the Building Information Model (2), order construction materials from suppliers (3) and, based on the design, construct the actual building (4)

the final layout of the play board. These are the most important game design changes:

- Removed playing cards with risk events (to make it more realistic and to increase comparability of multiple game plays).

- Implemented a rule that would pose a risk of late deliveries to the player (to reintroduce an element of uncertainty).

- Increased the number and detail level of client requirements (to make it more realistic and to increase comparability of multiple game plays).

- Changed the layout of the play board and simplified the game instructions (to increase understandability of the rules).

- Created two variants of the same game (to enable players experimenting with different problem-solving strategies and to track their progress).

All in all, this resulted in the final version of a serious game for construction supply chain management called Tower of Infinity (see also Figure 15 and Table 17). This one-player board game challenges players in their role of main contractor to design and construct a tower with LEGO bricks. It starts with 


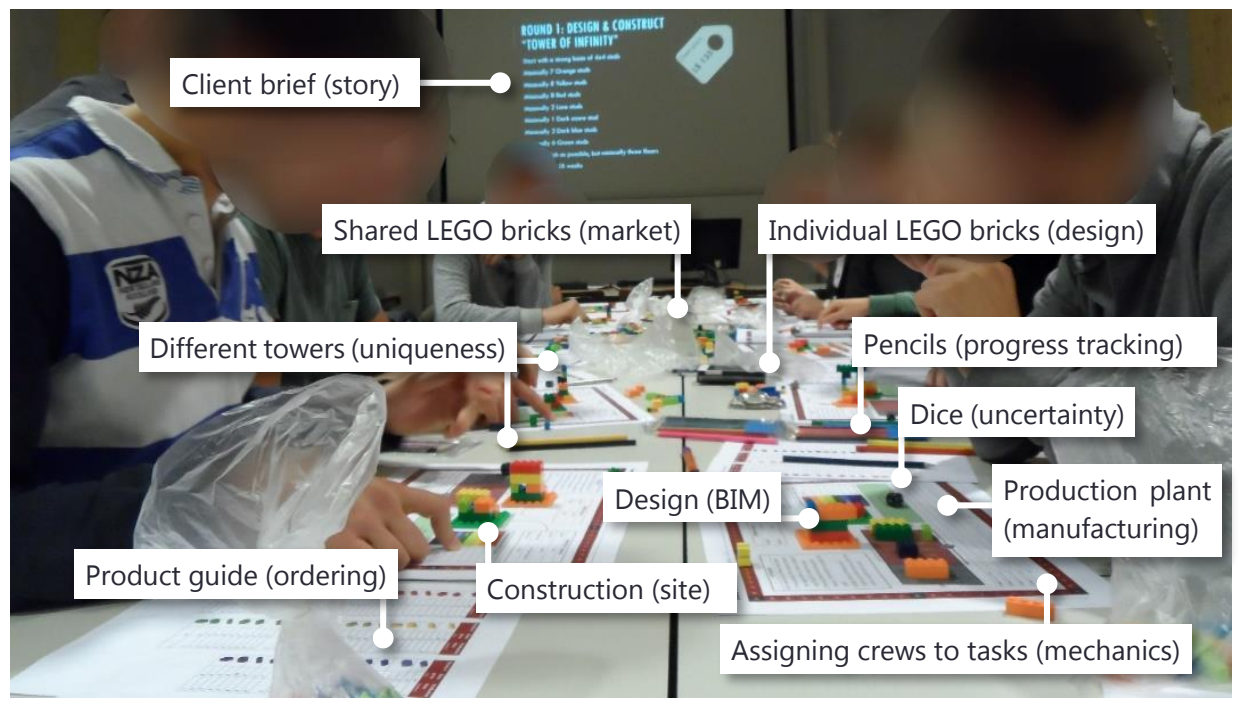

Figure 15: Illustration of main Triadic Game Design elements incorporated in 'Tower of Infinity'

displaying client requirements on a screen, such as to "build as high as possible" (hence the name of the game). Each player can then assign her/his own (four) multi-skilled crews to modeling, ordering and/or assembling actions/tasks. A crew can be assigned to a task by writing down the action in a project schedule and executing the task (e.g. for assembling: writing down an ' $\mathrm{A}$ ' and stacking a manufactured - brick on the LEGO plane representing the site). One crew can be assigned to one task in a round/week, which means that a player can conduct four actions per round. A dice is thrown at the start of each round to determine in which supplier's production stage (represented by a conveyor belt) an ordered brick is delayed with one week (unless the player decides to invest a bit and undo the delay). Bricks of which manufacturing is completed are freely stored on-site until assembling starts (but a fee needs to be paid for external, temporary storage if there is insufficient on-site space). The game is finished when the Tower of Infinity is fully designed and constructed. The objective thereby is to maximize profit through efficient supply chain management.

\section{Research methodology}

The aim of the presented research is to explore how serious games can contribute to experiential learning about construction supply chain management. This was studied within the context of a master's course, the main research subjects being construction management students: the workforce of the 
Table 17: Game rules and objectives

\begin{tabular}{|c|c|}
\hline Game rules & Client brief \\
\hline $\begin{array}{l}\text { Each week (round), follow these steps: } \\
\text { Throw the dice. The number indicates } \\
\text { the stage in which } 1 \text { brick is delayed (if } \\
\text { any). Pay L\$ } 3 \text { to undo the delay. } \\
\text { Move all other bricks through the } \\
\text { factory - from the left one stage to the } \\
\text { right. } \\
\text { Assign crews to Design and/or } \\
\text { Construction tasks (actions). Each crew } \\
\text { can do one action per round. }\end{array}$ & $\begin{array}{l}\text { Client pays L\$ } 135 \\
\text { Start with a strong basis of } 4 \times 4 \text { studs } \\
\text { No Yellow bricks } \\
\text { Minimally } 4 \text { Lime studs } \\
\text { Minimally } 7 \text { Dark azure studs } \\
\text { Minimally } 2 \text { Blue studs } \\
\text { Minimally } 4 \text { Dark blue studs } \\
\text { Minimally } 8 \text { Red studs } \\
\text { Minimally } 7 \text { Orange studs } \\
\text { Minimally } 8 \text { Green studs } \\
\text { Build as high as possible (minimally } 4 \text { floors) } \\
\text { Finish within } 23 \text { weeks }\end{array}$ \\
\hline
\end{tabular}

future. With reference to the world of Meaning, the authors hypothesized that serious games for construction supply chain management can enable students to experientially learn improving the performance of a construction supply chain through:

- Coordinating design and construction tasks in a coherent manner;

- Taking constructability aspects into account when designing;

- Continuously balancing scope, time and cost throughout a project.

To provide evidence for these hypotheses, the authors qualitatively analyzed how the board game supported experiential learning about construction supply chain management in a master's course. This case study made it possible to investigate how playing serious games supported construction supply chain management education.

\section{Collecting data: play sessions during master's course}

During two subsequent years, the authors facilitated (in total) four play sessions of the serious game Tower of Infinity as part of a master's course on construction supply chain management at a university in the Netherlands. The relevant course aims to teach students how to apply supply chain and purchasing management concepts from other industries to construction. It consists of two parts: (1) a part in which students are introduced to many scientific literatures on supply chain 
management, purchasing and the role of building information modeling in construction supply chains and, subsequently, (2) a practical assignment in which students need to do field work. The play sessions took place at the end of the first part, after the students were introduced to the aforementioned theoretical concepts.

The game was played by a total number of 64 students ( 40 in the first year and 24 in the second). Both years that the game was played, the group was split into two. The first-mentioned author started all four play sessions with explaining the rules of the game ( $15 \mathrm{~min}$ ). The students then played their first (trial) game round (30 $\mathrm{min}$ ) while the game facilitators answered any questions regarding the rules. This round was followed with a break, in which the facilitators took pictures of the final status of each game. After the break, the students started from scratch and played a second game round ( $30 \mathrm{~min}$ ). These rounds ended again with taking pictures and announcing an obligatory assignment related to the serious game (15 min). In comparison to the first year that the authors facilitated play sessions, they cleared some ambiguities in the explanation and simplified the trial game round in the second year (but kept the game set-up, rules and objectives the same). The assignment asked the students to reflect on their game play by answering the following three questions in a one-page document:

- How do you see the theoretical ideas from the course back in the game?

- To what extent did you change your strategy in the second play of the game?

- To what extent do you think that the game represents real-world supply chain management problems?

In line with experiential learning theory, these questions were meant to stimulate students to critically reflect on their game play experiences and thereby to connect theory with practice. Their reflection reports represent a tried-and-true (yet less common) post-assessment method that has the advantage of enabling players to articulate their thoughts in ways that are most meaningful to them (Chin et al., 2009) and, as such, can help to reveal how and why they applied certain strategies. Together with the pictures, these reports provided an important data source for the authors (as researchers) to test the previously formulated hypotheses.

\section{Analyzing data: content analysis of reports and pictures}

The authors performed a content analysis of the data collected. Content analysis involves the tagging of data with codes derived from prior knowledge and then analyzing the distribution of the codes - with the aim to explore explicit and covert meanings in the data (Bernard \& Ryan, 2010). The first-mentioned author 
therefore created a set of codes based on the three hypotheses. This researcher and one other independent researcher individually pretested these codes on a few randomly selected student reports and pictures, discussed differences in coding and then refined the coding scheme. They then applied the codes to the rest of the data: for each of the 64 game sessions both coders investigated whether the player was aware of specific learning goals/hypotheses (coded with a 1) or not (0). This resulted in two case-by-variable matrices. The first researcher had thereby added qualitative evidence supporting the inferences (excerpts of text, notes) to extra columns of his matrix. Intercoder reliability was assessed with Cohen's kappa ( $\mathrm{K}$ ), a statistic that measures how much better than chance the agreement between a pair of coders is with regard to the presence or absence of binary (yes/no) themes in data (Bernard \& Ryan, 2010). Adequate agreement was found between the two coders $(\kappa=0.76)$. The coders then discussed and resolved the (50) discrepancies (out of 512 items) in their coding. The authors then used the final data matrix to compare and contrast similar game sessions with each other to try to understand how and why certain game mechanisms contribute to the individual experiential learning processes.

\section{Findings}

The authors hypothesized that serious games could contribute to experientially learning about construction supply chain management. This section presents the findings (with descriptive statistics in Table 18).

\section{Hypothesis 1: supply chain improvement through coordinating design and construction tasks coherently}

First, the authors hypothesized that serious games enable students to experientially learn improving the performance of a construction supply chain through coordinating design and construction tasks in a coherent manner.

It was found that students were able to take a systems perspective of the entire supply chain. The game enables players to Order construction materials at a supplier, which are then produced (make-to-order) and transported to the site. These steps connect upstream (Modeling) and downstream (Assembling) processes with each other. Players found that these design and construction processes are interrelated and need to be viewed as a whole. One phrased, for example, "[the] different elements within the supply chain are dependent upon each other, and strategic decisions need to be made in order to have an efficient construction process" (player 22). "All processes that have to be done to get to 
Table 18: Descriptive statistics of evidence found from the content analysis of data collected during a construction supply chain management master's course. Numbers referring to the instances confirming the hypothesis $(n=64)$

\begin{tabular}{l|l|l}
\hline $\begin{array}{l}\text { Hypothesis - players } \\
\text { experientially learn improving } \\
\text { a construction supply chain } \\
\text { through: }\end{array}$ & Variable/theme & $\begin{array}{l}\text { Instances of } \\
\text { confirmation }\end{array}$ \\
\hline $\begin{array}{l}\text { (1) Coordinating design and } \\
\text { construction tasks coherently }\end{array}$ & $\begin{array}{l}\text { uses systems perspective to focus on entire } \\
\text { supply chain } \\
\text { tries to achieve a lean process and/or Just- } \\
\text { In-Time deliveries }\end{array}$ & 58 \\
\hline $\begin{array}{l}\text { (2) Taking constructability } \\
\text { aspects into account when } \\
\text { designing }\end{array}$ & $\begin{array}{l}\text { recognizes construction sequences } \\
\text { adapts strategy based on product lead-times } \\
\text { and assembling rates }\end{array}$ & 47 \\
\hline $\begin{array}{l}\text { (3) Continuously balancing } \\
\text { scope, time and cost }\end{array}$ & $\begin{array}{l}\text { bases design on availability of materials and } \\
\text { makes systematic trade-offs to fulfill client } \\
\text { requirements }\end{array}$ & 28 \\
\hline $\begin{array}{l}\text { balances time and cost when ordering } \\
\text { construction materials } \\
\text { makes trade-offs in response to } \\
\text { manufacturing delays }\end{array}$ & 53 \\
\hline
\end{tabular}

the end-product are interconnected" wrote another (player 39). Players come to similar conclusions since they observed that "decisions made during the design phase have a great impact on the assembly phase" (player 3). Particularly at the very start of the game, students regularly "overlooked, neglected or approached [the dependencies] in a wrong way" (player 16), which resulted in "problems discussed during the lecture" (player 24), like budget and schedule overruns. For example, player 44 was initially "just ordering some materials and then assembling them on the construction site" without taking into account some important aspects of the supply chain" such as product lead-times, which led to "significant losses in terms of idling construction crews." That illustrates player 28 's conclusion that there is "a need for coordination and planning" at the level of the complete supply chain. As summarized by one, the "striking theoretical concept that is represented in the game, is the concept of the systems approach" (player 9).

The game also enabled students to streamline work flows as in lean construction. Players have four crews available during the design and construction processes. 


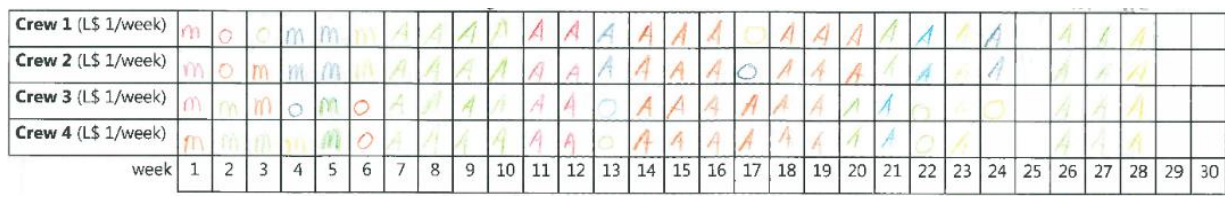

Figure 16: Project schedule with empty squares (emphasis added) indicating idle crews in week 24 and 25. This form of waste is a consequence of the late order and delivery of a green and yellow brick

These crews also need to be paid when they are idle and thus it is most efficient "to keep the crews occupied every week" (player 25). The strategy to "maximize the efficiency of the labor" (player 42) was identified by many as a lean approach of supply chain management and "the most obvious" theoretical idea of the game (player 58). Players that had many idle crews indeed conclude that their ingame process was "very inefficient and costly" (player 12) or even "an economic failure" (player 4). Player 25, for example, could not assign any tasks to some crews in week 24 and 25 since they were waiting for the delivery of a green and a yellow brick on the site (Figure 16). The empty squares in a project schedule give an indication of the waiting times. This could be significant according to player 33 , since "most waste was caused by unproductivity after the design phase."

Another indicator for waste is the fee that needs to be paid if a brick that is being delivered cannot be stored on the construction site. When manufacturing of a brick is finished, it is transported to the construction site and stored there until assembling can commence. However, a fee for temporary, external storage needs to be paid if there is not enough space available on the site. This invoked the next reaction of player 4: "by the implementation of costs for temporary storage, the application of the lean principle together with just in time delivery (JIT) became more and more understandable, as these costs do strongly increase the overall costs." Similarly, another said that a game aspect that was clearly noticeable "was the importance of Just-In-Time production to eliminate possible storage cost and ensure the full utilization of construction workers" (player 3). This person therefore concluded that "the most important theoretical lesson from the game is the importance of synchronizing the supply chain in such a way the design, [manufacturing] and [assembling] phase perfectly fit together."

In sum, the students' reflections are clear and consistent that the game enabled them to optimize the supply chain by taking a systems perspective, trying to streamline work flows and to pursue Just-In-Time deliveries. 
Hypothesis 2: supply chain improvement through taking constructability aspects into account when designing

Second, the authors hypothesized that serious games enable students to experientially learn improving the performance of a construction supply chain through taking constructability aspects into account when designing.

It was found that the game helped students to understand how desired construction sequences influence the design. The LEGO building that players make needs to be assembled from the ground floor up. The vertical, logical construction sequence that this implies fosters players to consider "the order in which the construction will be [built]" already during the design stage (player 38). A number of students identified the challenge of "vertical assembly versus horizontal production" (player $25,38 \& 43$ ). Some of them explicitly confirmed that "more attention was [paid] to [a] logical sequence of building component location" in the second round of the game (player 18). This is, for example, possible by stacking a LEGO brick on top of only one other brick that has been assembled completely (whereas building on top of multiple bricks would also require the assembly of multiple bricks to be finished). Thus "one [brick] should be stacked upon only one other [brick]. If this is not the case, you increase your chances for delay" (player 63). Another one applying this idea chose to design a brick with a long assembling time "on a place where the [brick] does not have relevance at all" and "then not build on top of that" (player 14) (Figure 17). This improved the performance of the supply chain as "every open spot in the schedule of the workers could [now] be filled with 'assembly' of that [brick].

There is also ample evidence that students base their designs on information regarding product lead-times and assembling rates. Depending on the brick size and color, some suppliers promise a fast product delivery while others have a longer lead-time - as specified in a product guide. The effort needed to finish assembling a LEGO brick differs per color. A red LEGO brick of a certain size may require 4 in-game actions (for example: 2 crews working 2 weeks, or 4 crews working 1 week), while an orange brick of that same size may require 12 assembling actions. "How much time does the production or assembling [take]?" and "Is it useful to use that brick first?" are therefore relevant questions to ask, according to player 16. Indeed, product lead times and assembling rates affected project outcomes: "In the first game, there was a problem because I had to wait two weeks because of the production of the orange brick [by the supplier] which also needed six weeks to assemble [on site]. This was a lesson for me, so in the second game I based the choice of the bricks more on the assembling rates to save time" (player 36). Another also argued to achieve an optimization in that way: "I started by [analyzing] the requirement[s], and analyzed the material cost 


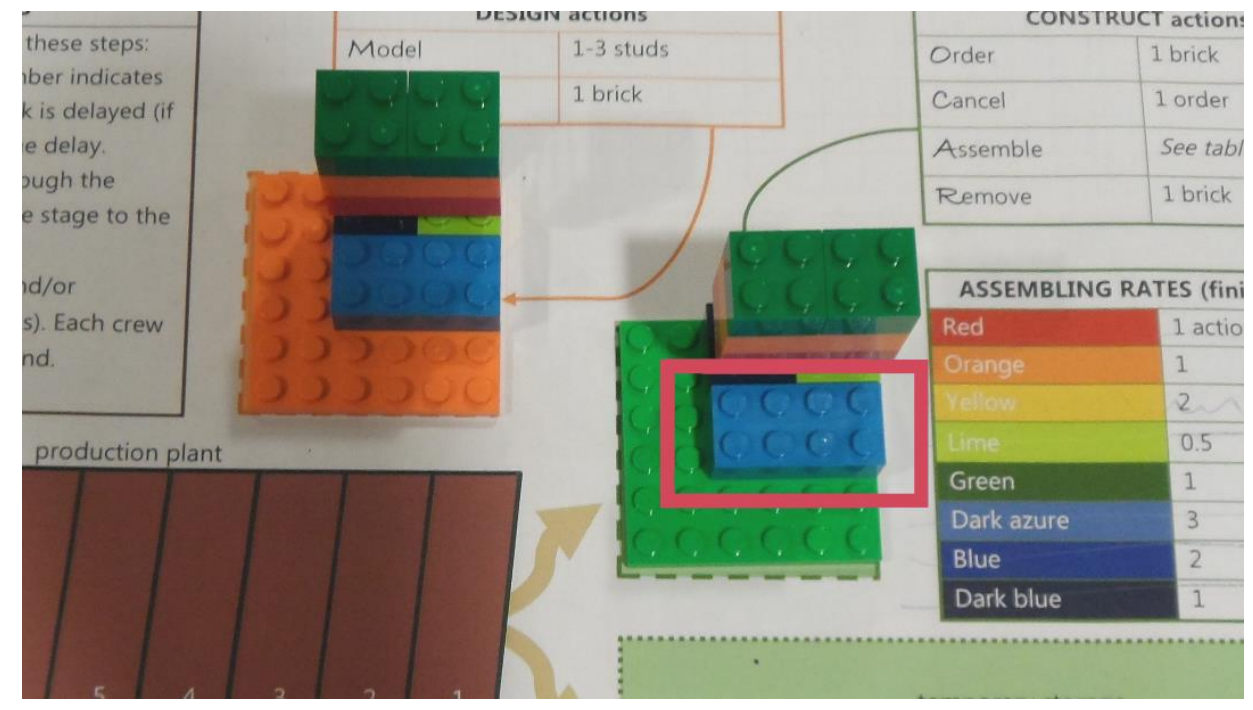

Figure 17: Informed by the assembling rates, a player decides not to design (and build) on top of the dark azure brick so that it is no longer in the critical path and assembling of this brick can be finished whenever possible (player 14)

and production time. [Then I started] modeling and [...] ordering based on the production time of the material. [...] The second round I did so much better than the first round" (player 17). Along with the authors' observations, the pictures taken support their stories: in the second game round, these players have less idle crews waiting (empty squares in the schedule) than in the first round.

There is some evidence that students adapt their designs based on the availability of construction materials and construction site characteristics. When players order a brick, they pick it from a 'market of construction materials' and then place it on a supplier's 'conveyor belt'. The number of available bricks in the market is, however, limited and this requires one to "be on time to get the materials you needed or you could choose to use only the materials with the sufficient supply stock" (player 30 ). This "perfectly simulates the dependence on the market" according to player 9 , but not all players seemed to realize this. In a few occasions, the authors even observed that some players 'bended the rules of the game' by picking two smaller green bricks when the larger one that they needed was no longer available (while they should have just ordered two smaller ones or changed the design). According to player 34, it is a "real-world problem" that a "designer makes a design, but the constructor cannot acquire the right materials and has to work with other (and more expensive) materials." These players prevented "rework and delays" (player 38) by timely considering the availability of materials. 
Finally, it was found that the designs of some students were informed by construction site characteristics. The construction site is represented in the game by a $6 \times 6$ studs LEGO plane of which the client requires that "a strong basis of $4 \times 4$ studs" is used for the tower's ground floor. There is thus little space available to store any manufactured bricks on the site. As external, temporary storage is relatively expensive and delays may occur, the game rules force players to think ahead about where they will store any fully manufactured bricks. "This means you can play the game strategic and build on the sides of the construction site" (player 32) so that space remains available for on-site storage. Indeed, one person with the strategy to "design and build in the corner of the [site]" reflected that she "did not have to pay for renting temporary storage in the second round of the game" (player 54). There are nevertheless few players that made similar reflections and also the pictures reveal that most actually did the opposite by building in the center of the site, thus leaving practically no space for storing any bricks.

Summarizing, the evidence shows that the game helped students to improve their construction supply chains by taking constructability aspects into account such as the desired construction sequence, product lead-times and assembling rates, the availability of materials at the market and construction site characteristics.

Hypothesis 3: supply chain improvement through continuously balancing scope, time and cost throughout a project

Third, the authors hypothesized that serious games enable students to experientially learn improving the performance of a construction supply chain through continuously balancing scope, time and cost throughout a project.

There is abundant evidence showing that students could recognize the need to make systematic trade-offs to fulfill the requirements. The game starts with the "translation of the requirements to your design" (player 38) and the main challenge is "matching the requirements of the client with the limited resources (time and money) available" (player 1). Most requirements define a certain minimum quality level, such as "minimally 8 red studs." This suggests that more "value to the project" (player 18) can be delivered by building higher and/or more. Since the project time and lump sum payment are fixed, "trade-offs [...] have to be made" (player 47). One of the players clearly describes how he initially experienced how scope, time and cost are interrelated and how he then used that experience to achieve some supply chain optimizations: "In the first play I did manage to fully meet the design requirements both within time and budget, 
however I continued with building till the end of the weeks given for the project. This meant that I built more than demanded, which also resulted in a budget overrun. [...] However, in the second play I only focused on the design requirements and decided to stop with building when these were met. This meant I stayed within budget this time and also within time" (player 4). This illustrates how players were able to balance the project's scope against time and cost.

The game also enabled students to balance time and cost when ordering construction materials. For each kind of material, a product guide displays one or multiple options (with variations in lead-time and cost) that the player can choose from. So, "continuously one should trade off the costs against the lead times" (player 9). Players experienced how they could make these trade-offs throughout the game. For example, one explained: "The first time I didn't [have] a real strategy. I just modeled the building and decided to spend [as] less time as possible in the production plant, consequence of this decision were higher production costs" (player 22). She changed this strategy as she found that "sometimes it isn't necessary to pay more for a faster production because you have to wait with construction [as] other parts [...] are not finished yet." Similarly, player 53 reflected on a wrong trade-off in the first game round: "the expensive/fast yellow [brick] was a mistake, because the brick was laying on the building site 5 weeks before it could be assembled." Another person wrote that "two bricks were not ordered in time [...] resulting in a budget and time overrun" (player 25). However, the authors' pictures show that he chose - at that particular moment - to pay more for these bricks so they would be delivered faster. Since a standstill in the project is more expensive, this prevented an even higher budget and time overrun. As concluded by one, choosing "the right combinations could lead to great profits in the end" (player 30).

Players also made trade-offs to deal with manufacturing delays. Within the game, players throw a dice to identify the manufacturing stage in which one brick is delayed. This "can have a big impact to the whole project especially related to time and cost" (player 17). Player 15 argued that delays "happen in every stage of the supply chain and for various reasons. The game illustrates this well because the delays can totally mess up the [assembling] process. As a result, a lot of the finished bricks will end up in the temporary storage, which costs extra money." The game rules allow players, however, to speed up the process and undo a delay by paying a certain fee. With reference to such delays, player 12 argues that "choices [...] should be made in order to stay on track and budget." Describing his two game rounds, player 27 wrote that a "difference between the first and last game [was] the penalties paid for [undoing a manufacturing] delay [...]. In the first game I accepted the delay in the second game this was not possible 
anymore because on a [certain] moment the complete design was in production leading [to] more penalties for delays and more penalties for storage [outside of] the construction site." Another decided that it was not necessary to pay for undoing a delay. "This was because there was always an opportunity for the crews to assemble another brick instead" (player 53). Players have thus been balancing one-week delays against fees to speed up manufacturing with the aim to improve the overall result.

All in all, students were able to optimize the supply chain throughout the game by balancing the project's scope with time and cost, balancing time and cost when ordering construction materials and by balancing manufacturing delays against fees to speed up those delays.

\section{Discussion}

This paper aimed to explore how serious games can contribute to experiential learning about construction supply chain management. The authors therefore methodically developed a serious game ('Tower of Infinity') that simulates an integrated (Design \& Construct) project in which a player takes on the role of a main contractor and assigns crews to modeling, ordering and assembling tasks in order to meet client requirements within certain boundaries. The authors then investigated the use of this serious game in a master's course to provide qualitative evidence for three hypotheses. By doing so, this paper has two main contributions. First (and foremost), it contributes to the field of construction supply chain management by reflecting on the use of an innovative serious game that deals with the peculiarities of supply chain management for construction. Second, the paper contributes to serious gaming literature by illustrating the serious game design process with a case for construction supply chain management.

\section{Experiencing supply chain optimizations: evidence for three hypotheses}

One reason for the great amount of waste and problems in construction is that it is hard to acquire experience in coordinating supply chain activities. Graduate students are often poorly prepared to deal with real-world supply chain management problems since educational assignments, on one hand, usually ignore many of the peculiarities found in practice and stories of best practices, on the other hand, cannot provide them with the thick context that is necessary to understand those practices. With their theoretical foundation in experiential learning theory (Kolb 1984; Kolb et al. 2001), serious games have previously been 
found powerful to give a meaningful experience to their users though. Previous studies on serious games have nevertheless not dealt with supply chain management practices specific to the construction industry, did not follow a methodical approach for designing a game and/or lack robust and transparent reflections. This study is an attempt to address those issues.

Firstly, this study shows that serious games can enable students to experientially learn how coordinating design and construction tasks in a coherent manner helps to improve the performance of the construction supply chain. The construction management students who played the proposed serious game reflected that the game helped them to get a systems perspective of the entire supply chain. Players recognized that the modeling, ordering, (manufacturing/waiting) and assembling activities that the game includes are interrelated and therefore need to be seen as a whole. Their attempts to streamline these activities and achieve Just-In-Time deliveries reduced or even prevented waiting times. This was further promoted by another game feature: a fee for temporary, external storage that needs to be paid if construction materials cannot be stored on site. The players' systems perspective and attempts to synchronize activities thus helped to minimize waste and thereby resulted in more efficient construction supply chains.

Secondly, this study shows that serious games can contribute to learning that taking constructability aspects into account during the design stage can improve the performance of the construction supply chain. The authors provided evidence that players adapted their designs to a desired construction sequence. They made strategic choices to efficiently cope with the game rule that upper bricks can only be assembled when lower bricks are finished. Similarly, players also took construction information regarding product lead-times and assembling rates into account when they worked on a design, which ultimately led to less waste (waiting times). It was also found that some players considered the availability of construction materials and construction site characteristics for their designs. So, players dealt with constructability issues during the design, such as the desired construction sequence, product lead-times and assembling rates, the market availability of construction materials and construction site characteristics.

Thirdly, the study shows that serious games can help students to learn how continuously balancing scope, time and cost throughout a project helps to improve the performance of the construction supply chain. Players recognized how systematic time and cost trade-offs helped to fulfill the client requirements. While ordering material, players had to choose between various alternatives using a product guide. The authors showed how carefully selecting the right combinations throughout the game led to greater profits in the end. A game rule 
that enabled players to undo a certain manufacturing delay finally enabled players to balance an investment fee against a delay in delivery. Thus, players achieved overall optimizations by matching the project's scope with available time and cost and by balancing time and cost when ordering construction materials and manufacturing delays against fees to speed up such delays.

It is apparent from the above discussion that serious games can contribute to experiential learning about construction supply chain management in a number of ways. Next to that, the authors found that the students were able to connect the game with theories discussed during their (earlier) lectures as well as with construction practice. That is important for the serious game to have a meaningful effect beyond the game itself. It was also observed that students seemed genuinely interested in and had fun while playing the game: they were all very focused (completely silent), particularly during the second game round, wanted to continue playing during the break and sometimes added positive comments related to the plays to their reflection reports. Educators may appreciate these insights about enriching construction supply chain management education with a serious game.

Finally, this work contributes to serious gaming literature with a case for construction supply chain management. The authors illustrated how a serious game was developed for this discipline by defining the inhabitants of the worlds of Reality, Meaning and Play (Harteveld, 2011). According to the Triadic Game Design approach, these worlds need to be balanced for an effective game. An optimum balance was found after a game play workshop with international construction management educators. Their pertinent feedback helped to assess the right balance between the three worlds. From this, the authors suggest that the three worlds of Reality, Meaning and Play can also be used as a framework to systematically criticize and redesign a serious game.

\section{Limitations and directions for future research}

As with all studies, this study has a number of limitations from which directions for further research are suggested.

This research has not assessed whether serious games for construction supply chain management are more effective than other educational means. We focused on exploring how serious games can contribute to experientially learning relevant to the domain. Although our evidence is compelling, it only tells us that serious games contribute to experiential learning. It remains unclear whether serious games are also more effective than other educational means. An experimental research design could help to answer this question. Although there 176 | Experiencing supply chain optimizations: A serious gaming approach 
is a longstanding debate in serious gaming literature about appropriate assessment methods, a pre- and post-test with a control group seems to be favored to assess the effectiveness of a serious game (Bellotti et al., 2013; Chin et al., 2009; Clark, 2007).

There are also a number of issues with the serious game itself. Most importantly, some players criticized that all buyer-supplier relationships are conceptualized as arm's-length relations. One game rule is namely that the player throws a dice at the beginning of each turn (week) and, with that, determines in which manufacturing stage an order is delayed. Since the orders at each supplier are subject to this rule, the game does not help students to experiment with different types of relationships and appropriate management styles such as described by Bensaou (1999). On the other hand, arm's-length relationships are actually still most common in construction practice. In that respect, we argue that our game has at least made people think about whether these kind of relationships are indeed most desirable to achieve more efficient supply chains. It may also be questioned whether the game sufficiently conveys day-to-day supply chain practices, since a prototypical version was play-tested by construction management educators (rather than practitioners). Some other minor game issues that came to the surface are that some game rules were initially hard to understand (particularly the assembling actions), writing all moves down was not so intuitive and errors were easily made. Future research could thus focus on dealing with these game design issues and on testing it with practitioners.

Finally, the lack of a structured debriefing has downplayed learning possibilities. A crucial part of experiential learning, apart from the (game) experience in itself, is the reflection on that experience. For methodological reasons, we chose to foster independent reflections through obligatory student assignments. We are confident that the decision not to steer student answers in a certain direction has helped to safeguard objectivity. However, not everyone is equally capable of analyzing, making sense and assimilating learning experiences on their own. Skilled facilitators can then play an important role in addressing this natural gap by guiding the reflective process in a collective debriefing (Fanning \& Gaba, 2007). The absence of a debriefing may have limited student reflections and weakened our findings accordingly.

\section{Conclusions}

This paper presented a serious gaming approach for construction supply chain management. Based on the study's findings, it is concluded that serious games can contribute to experientially learning about construction supply chain management. Serious games are viable educational tools to support experiential 
learning. They can enable students to experientially learn improving the performance of a construction supply chain through: (1) coordinating design and construction tasks in a coherent manner; (2) taking constructability aspects into account when designing; and (3) continuously balancing scope, time and cost throughout a project. Experiencing such supply chain optimizations in a playful way helps to better understand how and why waste occurs and may, ultimately, contribute to more efficient construction supply chain management practices.

\section{Acknowledgements}

The research work presented in this paper was partly funded by the European Commission (543923-TEMPUS-1-2013-1-EG-TEMPUS-JPCR). The authors would like to thank Ruth Sloot and Sander Siebelink for their assistance during game play sessions. The authors also gratefully acknowledge the anonymous reviewers for their constructive feedback.

\section{References}

Al-Jibouri, S. H., \& Mawdesley, M. J. (2001). Design and experience with a computer game for teaching construction project planning and control. Engineering, Construction and Architectural Management, 8(5-6), 418-427.

Albert, A., Hallowell, M. R., Kleiner, B., Chen, A., \& Golparvar-Fard, M. (2014). Enhancing construction hazard recognition with high-fidelity augmented virtuality. Journal of Construction Engineering and Management, 140(7), 04014024.

Arunachalam, R., \& Sadeh, N. M. (2005). The supply chain trading agent competition. Electronic Commerce Research and Applications, 4(1), 66-84.

Bak, O., \& Boulocher-Passet, V. (2013). Connecting industry and supply chain management education: exploring challenges faced in a SCM consultancy module. Supply Chain Management: An International Journal, 18(4), 468-479.

Bankvall, L., Bygballe, L. E., Dubois, A., \& Jahre, M. (2010). Interdependence in supply chains and projects in construction. Supply Chain Management: An International Journal, 15(5), 385-393.

Battini, D., Faccio, M., Persona, A., \& Sgarbossa, F. (2009). Logistic Game ${ }^{\mathrm{TM}}$ : learning by doing and knowledge-sharing. Production Planning \& Control, 20(8), 724-736.

Bellotti, F., Kapralos, B., Lee, K., Moreno-Ger, P., \& Berta, R. (2013). Assessment in and of Serious Games: An Overview. Advances in Human-Computer Interaction, 2013, $1-11$.

Bemelmans, J., Voordijk, J. T., \& Vos, B. (2012). Supplier-contractor collaboration in the construction industry. Engineering, Construction and Architectural Management, 19(4), 342-368.

Bensaou, M. (1999). Portfolios of buyer-supplier relationships. MIT Sloan Management Review, 40(4), 35.

178 | Experiencing supply chain optimizations: A serious gaming approach 
Bernard, H. R., \& Ryan, G. W. (2010). Analyzing qualitative data: Systematic approaches. Thousand Oaks, CA: SAGE publications.

Chin, J., Dukes, R., \& Gamson, W. (2009). Assessment in simulation and gaming: A review of the last 40 Years. Simulation \& Gaming, 40(4), 553-568.

Clark, R. E. (2007). Learning from serious games? Arguments, evidence, and research suggestions. Educational Technology, 47(3), 56-59.

Connolly, T. M., Boyle, E. A., MacArthur, E., Hainey, T., \& Boyle, J. M. (2012). A systematic literature review of empirical evidence on computer games and serious games. Computers \& Education, 59(2), 661-686.

Corsi, T. M., Boyson, S., Verbraeck, A., Van Houten, S., Han, C., \& Macdonald, J. R. (2006). The real-time global supply chain game: New educational tool for developing supply chain management professionals. Transportation Journal, 61-73.

Cox III, J. F., \& Walker, E. D. (2006). The poker chip game: A multi-product, multi-customer, multi-echelon, stochastic supply chain network useful for teaching the impacts of pull versus push inventory policies on link and chain performance. INFORMS Transactions on Education, 6(3), 3-19.

Deshpande, A. A., \& Huang, S. H. (2009). Simulation games in engineering education: A state-of-the-art review. Computer Applications in Engineering Education, 19(3), 399-410.

Dossick, C. S., Mukherjee, A., Rojas, E. M., \& Tebo, C. (2010). Developing Construction Management Events in Situational Simulations. Computer-Aided Civil and Infrastructure Engineering, 25(3), 205-217.

Dubois, A., \& Gadde, L. E. (2000). Supply strategy and network effects - purchasing behaviour in the construction industry. European Journal of Purchasing \& Supply Management, 6(3-4), 207-215.

Dzeng, R. J., \& Wang, P. R. (2017). C-Negotiation Game: An educational game model for construction procurement and negotiation. Automation in Construction, 75, 1021.

Eastman, C., Teicholz, P., Sacks, R., \& Liston, K. (2011). BIM Handbook: a guide to Building Information Modeling. Hoboken: John Wiley \& Sons.

Fanning, R. M., \& Gaba, D. M. (2007). The role of debriefing in simulation-based learning. Simulation in healthcare, 2(2), 115-125.

Fawcett, S. E., \& McCarter, M. W. (2008). Behavioural issues in supply chain collaboration: communicating the literature via interactive learning. International Journal of Integrated Supply Management, 4(2), 159-180.

Harteveld, C. (2011). Triadic game design: Balancing Reality, Meaning and Play. Heidelberg: Springer.

Hartmann, T., Van Meerveld, H., Vossebeld, N., \& Adriaanse, A. (2012). Aligning Building Information Model tools and construction management methods. Automation in Construction, 22, 605-613.

Hegazy, T., Abdel-Monem, M., Saad, D. A., \& Rashedi, R. (2013). Hands-On Exercise for Enhancing Students' Construction Management Skills. Journal of Construction Engineering and Management, 139(9), 1135-1143. 
Holweg, M., \& Bicheno, J. (2002). Supply chain simulation - a tool for education, enhancement and endeavour. International Journal of Production Economics, $78(2), 163-175$.

Hussein, B. (2015). A blended learning approach to teaching project management: a model for active participation and involvement: insights from Norway. Education Sciences, 5(2), 104-125.

Kolb, D. A. (1984). Experiential learning: Experience as the source of learning and development. Upper Saddle River: Prentice Hall.

Kolb, D. A., Boyatzis, R. E., \& Mainemelis, C. (2001). Experiential learning theory: Previous research and new directions. In R. J. Sternberg \& L. F. Zhang (Eds.), Perspectives on thinking, learning, and cognitive styles (Vol. 1, pp. 227-247): Routledge.

Koskela, L. (1992). Application of the new production philosophy to construction: Stanford University Stanford, CA.

Koskela, L., Howell, G., Ballard, G., \& Tommelein, I. (2002). The foundations of lean construction Design and Construction: Building in Value. Oxford, UK: Butterworth-Heinemann.

Kourmpanis, B., Papadopoulos, A., Moustakas, K., Stylianou, M., Haralambous, K. J., \& Loizidou, M. (2008). Preliminary study for the management of construction and demolition waste. Waste Management \& Research, 26(3), 267-275.

Kristiansen, P., \& Rasmussen, R. (2014). Building a better business using the LEGO SERIOUS PLAY method: John Wiley \& Sons.

Lindhard, S. (2014). Understanding the Effect of Variation in a Production System. Journal of Construction Engineering and Management, 140(11), 04014051.

Long, Q., \& Zhang, W. (2014). An integrated framework for agent based inventoryproduction-transportation modeling and distributed simulation of supply chains. Information Sciences, 277, 567-581.

Love, P. E. D., Irani, Z., \& Edwards, D. J. (2004). A seamless supply chain management model for construction. Supply Chain Management: An International Journal, 9(1), 4356.

Mawdesley, M., Long, G., Al-jibouri, S., \& Scott, D. (2011). The enhancement of simulation based learning exercises through formalised reflection, focus groups and group presentation. Computers \& Education, 56(1), 44-52.

Mikropoulos, T. A., \& Natsis, A. (2011). Educational virtual environments: A ten-year review of empirical research (1999-2009). Computers \& Education, 56(3), 769-780.

Min, J. U., \& Bjornsson, H. C. (2008). Agent-based construction supply chain simulator (CS2) for measuring the value of real-time information sharing in construction. Journal of Management in Engineering, 24(4), 245-254.

Namian, M., Albert, A., Zuluaga, C. M., \& Behm, M. (2016). Role of safety training: Impact on hazard recognition and safety risk perception. Journal of Construction Engineering and Management, 142(12), 04016073.

Nassar, K. (2003). Construction contracts in a competitive market: C3M, a simulation game. Engineering, Construction and Architectural Management, 10(3), 172-178.

Peterson, F., Hartmann, T., Fruchter, R., \& Fischer, M. (2011). Teaching construction project management with BIM support: Experience and lessons learned. Automation in Construction, 20(2), 115-125. 
Rojas, E. M., \& Mukherjee, A. (2005). General-purpose situational simulation environment for construction education. Journal of Construction Engineering and Management, 131(3), 319-329.

Rüppel, U., \& Schatz, K. (2011). Designing a BIM-based serious game for fire safety evacuation simulations. Advanced Engineering Informatics, 25(4), 600-611.

Sacks, R., Esquenazi, A., \& Goldin, M. (2007). LEAPCON: Simulation of lean construction of high-rise apartment buildings. Journal of Construction Engineering and Management, 133(7), 529-539.

Sacks, R., \& Goldin, M. (2007). Lean Management Model for Construction of High-Rise Apartment Buildings. Journal of Construction Engineering and Management, 133(5), 374-384.

Sacks, R., Radosavljevic, M., \& Barak, R. (2010). Requirements for building information modeling based lean production management systems for construction. Automation in Construction, 19(5), 641-655.

Schell, J. (2008). The Art of Game Design: A book of lenses. CRC Press.

Segerstedt, A., \& Olofsson, T. (2010). Supply chains in the construction industry. Supply Chain Management: An International Journal, 15(5), 347-353.

Son, J., \& Rojas, E. M. (2011). Evolution of collaboration in temporary project teams: An agent-based modeling and simulation approach. Journal of Construction Engineering and Management, 137(8), 619-628.

Sterman, J. D. (1989). Modeling managerial behavior: Misperceptions of feedback in a dynamic decision making experiment. Management science, 35(3), 321-339.

Susi, T., Johannesson, M., \& Backlund, P. (2007). Serious games: An overview. IKI Technical Reports.

Tommelein, I. D., Ballard, G., \& Kaminsky, P. (2008). Supply chain management for lean project delivery Handbook of Construction Supply Chain Management. Boca Ranton, FL: CRC Press.

Tommelein, I. D., Riley, D. R., \& Howell, G. A. (1999). Parade game: Impact of work flow variability on trade performance. Journal of Construction Engineering and Management, 125(5), 304-310.

Tsai, J. S., \& Chi, C. S. F. (2015). Learning for win-win collaboration. Journal of Construction Engineering and Management, 141(7).

Van Amstel, F. M. C., Zerjav, V., Hartmann, T., Dewulf, G. P. M. R., \& Van der Voort, M. C. (2016). Expensive or expansive? Learning the value of boundary crossing in design projects. Engineering Project Organization Journal, 1-15.

Vrijhoef, R., \& Koskela, L. (2000). The four roles of supply chain management in construction. European Journal of Purchasing \& Supply Management, 6(3-4), 169-178.

Watkins, M., Mukherjee, A., Onder, N., \& Mattila, K. (2009). Using agent-based modeling to study construction labor productivity as an emergent property of individual and crew interactions. Journal of Construction Engineering and Management, 135(7), 657-667.

Winch, G. M. (2010). Managing construction projects. Chisester: Blackwell Publishing Ltd.

Xue, X., Li, X., Shen, Q., \& Wang, Y. (2005). An agent-based framework for supply chain coordination in construction. Automation in Construction, 14(3), 413-430. 
182 | Experiencing supply chain optimizations: A serious gaming approach 
Discussion 


\section{Discussion}

This thesis has developed actionable knowledge of managing circular building projects. Dominant, linear construction practices favor the input of virgin resources which are readily available in an easy-to-use form and can be thrown away when no longer needed. Previous research has proposed remedies for the resulting socio-environmental problems. This research, alternatively, tried to address the root causes. Each of the previous chapters examined distinct information uses for management activities that aim to reduce, reuse and/or recycle building materials. The main contributions of these combined efforts are detailed insights into what demolition managers and design managers can do to close material loops. Below, I specify how those theoretical and practical contributions may guide in enabling circular buildings.

\section{Theoretical contributions to demolition management}

Demolition managers can use design information from both previous and later life-cycle stages to close material loops. Designers and architects produce information during a design phase to represent parts of an envisioned building, for example with sketches, floor plans, tables, (CAD) drawings or (BIM) models. It is well understood that this information is then used during the subsequent construction stage to deliver the actual building. A first key insight that this thesis adds is that the information can also be used (much) later: during demolition. Demolition managers can use previous design information, for example, to distinguish an appropriate disassembly routine - a necessary condition for choosing to recover any building object, hence enabling reuse instead of recycling (Chapter 1 ). While coordinating subsequent reuse or recycling activities, demolition managers can similarly reduce building uncertainty through the gathering, interpreting and synthesizing of design information (Chapter 2). The information can also be used to organize reverse logistics, for example to better understand existing conditions and to plan an efficient deconstruction sequence (Chapter 3). This suggests that demolition managers can use original building representations and specifications for several management activities. Another key insight is that demolition managers can use information from a later design phase, for example originating from a planned building transformation (or from an entirely different design project). Such design information can, for example, be used to assess the economic demand of any building object (Chapter 1) or, likewise, to reduce environmental uncertainty (Chapter 2). Demolition managers can also use this type of design information to label any reusable building elements and to indicate their different destinations (Chapter 3). Future design information can, accordingly, be used to anticipate reuse (or recycling) of 184 | Discussion 
building materials. There are, hence, two types of design information that demolition managers can use to close material loops, originating from previous and from later (circular) life-cycle stages. To distinguish between these two types, it is proposed to refer to these as, respectively, a priori and a posteriori design information (Figure 18). The related knowledge outputs of the first three chapters are discussed in detail below.

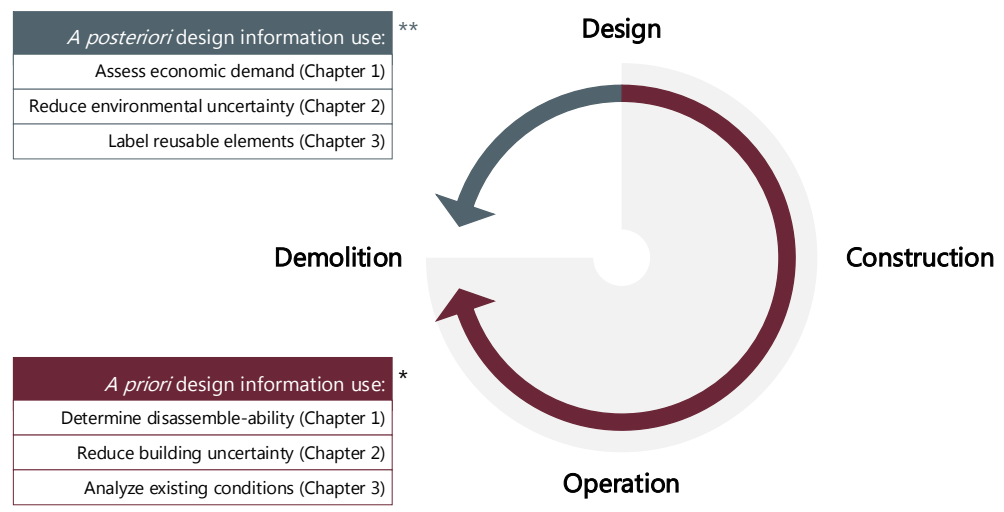

Figure 18: Demolition managers can keep building materials in the loop through leveraging a priori and a posteriori design information

* $A$ priori design information concerns any original representations and specifications of building materials

${ }^{* *}$ A posteriori design information concerns any plans to reuse (or recycle) recovered materials in the future

\section{A proposition for predicting building object recovery}

The first chapter developed a general proposition for predicting whether (or not) a demolition contractor will recover any building object. Contrary to previous studies that distinguished between, for example, components and elements, this chapter simply defined a 'building object' as any physical part of a building that can be handled separately. A review regarding reuse predictability suggested that previous studies focused on closing energy flows (rather than material flows), new objects for new buildings (rather than reusable objects from existing buildings) and generic barriers and drivers (rather than specific recovery practices from the demolition contractor's point of view). Targeting these knowledge gaps, we conducted foremost participant observations during a demolition project and used an analytic induction method to compare differences and similarities between the demolition contractor's decision to either recover or destruct building objects. 
Three necessary conditions were uncovered which together lead to the recovery of a building object for reuse. The first condition is that the demolition contractor identifies an economic demand for the object, for example through professional documents/contracts, direct on-site meetings or indirect sales channels. The second condition is that the demolition contractor distinguishes an appropriate routine to disassemble the object, which concerns the practical ability and willingness to disconnect it from other objects. The third condition is that the demolition contractor can control the performance of the object until it is reintegrated in a building, either through maintaining the physical and structural properties during storage times or through repairing any damages. Formulated as a proposition, the study poses that any object will only be recovered when all three conditions are satisfied. If one or more conditions are not satisfied, the object will be destructed.

The general proposition may be used to predict any future recovery decisions. Whether a demolition contractor is aware of it or not, it appears that such decisions are governed by a set of rules. Design (and other types of) information influence the outcome of a recovery decision. Contrary to previous research into (self-reported rather than actual) reuse practices, we did not find evidence for the popular belief that "going green" is an important motivation to recover objects. Changes to building codes, a well-documented barrier in literature (Hosseini et al., 2015; Kibert et al., 2001), were also not relevant here but may generally impact the economic demand of an object (our first condition). Since recovery decisions depend on specific situations, it is finally argued that reuse practices may be better understood in terms of conditions rather than static barriers and drivers.

The main contribution of Chapter 1 is thus that a building object will be recovered for reuse only when the demolition contractor: (1) identifies an economic demand for the object; (2) distinguishes appropriate routines to disassemble it; and (3) can control the performance until integration in a new building.

\section{Uncertainties and coordination mechanisms to explain end-of-life coordination}

The second chapter explains how demolition activities are coordinated after such recovery decisions are made. Based on a literature review, the study argued that (i) empirical studies on organizing demolition lack a sound theoretical perspective and that (ii) theoretical studies are deficient in explaining end-of-life coordination with data from real-world projects. We accordingly explored endof-life coordination through elaborating information processing theory 
(Galbraith, 1973, 1974, 1977; Tushman \& Nadler, 1978), a predominant framework which links the organizational design of a firm (providing information processing capacity) to uncertainties (causing information processing needs). A multiple-case study was presented with data from three real-world projects with different end-of-life strategies.

The study provided an explanatory account about how end-of-life activities are coordinated through processing information. Demolition contractors face building, workflow and environmental uncertainty. The specific levels of uncertainty differ per end-of-life strategy and result in different information processing needs. In the three cases studied, these firms responded with different sets of organizational measures. Demolition activities were more effectively coordinated when the information processing capacity resulting from those organizational measures matched with the information processing needs at hand. Characterizing the firms' organizational designs, the chapter explained that a 'separator' (demolition contractor) effectively coordinated material recycling in a faculty building transformation, a 'mover' did so for component reuse in a nursing home project, but a 'salesman' was ineffective to coordinate element reuse in a psychiatric hospital project.

The chapter contributes to existing studies with insights into uncertainties, organizational responses and their (mis)matches in different end-of-life strategies. As opposed to most studies adopting an information processing perspective (see e.g. Bensaou \& Venkatraman, 1995; Busse et al., 2016; Premkumar et al., 2005), the study used qualitative (rather than quantitative) data to study organizational activities. The conceptualization of a demolition contractor as an information processing system facing uncertainty provides new ways to explain coordination activities and to understand the firm's effectiveness. The perspective also helps in understanding the relevance of information during demolition activities. For buildings during the end-of-life phase, the chapter finally adds three (new) sources of uncertainty to the (classic) information processing theory: building, workflow and environmental uncertainty.

The main contribution of Chapter 2 is thus that a demolition contractor needs to take adequate organizational measures in response to specific levels of building, workflow and environmental uncertainty for the coordination of demolition/deconstruction activities to be effective.

\section{BIM uses for deconstruction practices}

The third chapter reflects on the iterative improvement of three BIM uses that support those deconstruction activities. A literature review (e.g. Kourmpanis et 
al., 2008; Koutamanis et al., 2018; Won \& Cheng, 2017) here pointed to a lack of knowledge about (i) the information that deconstruction workers use on site and (ii) how BIM-based methods could support their practices. An ethnographicaction research methodology (Hartmann et al., 2009) was therefore adopted to study and support work practices in an actual project: the systematic deconstruction of a nursing home (to enable material reuse and recycling).

Building on the insight that information is an important organizational contingency during deconstruction processes, we iteratively developed three (new) BIM uses: '3D existing conditions analysis', 'reusable elements labeling' and '4D deconstruction simulation.' Ethnographic methods firstly revealed that deconstruction workers used information to analyze existing conditions, label reusable building elements and plan deconstruction works. Action-oriented methods secondly revealed that (respectively) a 3D model can inform about building details and deconstruction methods, a virtual environment can present labeling information from a user's perspective, and a 4D simulation can show the planned deconstruction sequence.

These combined ethnographic-action perspectives add new empirical reflections on information usages and BIM-based methods to literature. The study strengthens our argument that information is not only relevant before deconstruction starts (see e.g. Akbarnezhad et al., 2014; Cheng \& Ma, 2013), but also during the site-based practices. Along the same lines, the chapter empirically showed that BIM-based methods can provide benefits to demolition contractors - in particular when those firms deal with deconstruction (rather than demolition). In doing so, the chapter identified the demolition contractor as a new potential user of BIM. This is a surprising contribution in itself given that even the most prominent and best cited BIM studies, which claim that the IT paradigm could be used during all life-cycle stages (e.g. Eastman et al., 2011; Succar, 2009), had not identified this type of firm as potential user before. We argue that with growing (circular) interest in recovering valuable materials, the interest of demolition contractors in BIM will also increase, as it offers them new digital possibilities for using information in their projects. Through reflecting on the methodology applied here, the chapter finally proposes to add a 'preparatory explorations' and a 'collaborative learning' step at the beginning and the end of the ethnographic-action research cycle, respectively.

The main contribution of Chapter 3 thus concerns three new BIM uses for deconstruction: '3D existing conditions analysis', 'reusable elements labeling' and ' $4 D$ deconstruction simulation'. 


\section{Theoretical contributions to design management}

Design managers, along the same lines as above, can use demolition information from previous and later life-cycle stages to close material loops (Figure 19). Conventional demolition methods simply turn a building into waste (Kourmpanis et al., 2008), which is recycled at best. This requires only little coordination between a demolition contractor and a waste processing firm. Demolition contractors with higher recovery and reuse ambitions, however, produce (demolition) information that can be relevant for designers. As illustrated in Chapter 2, demolition contractors may, for example, showcase any reusable building elements on an online marketplace. Previous studies discussed "some challenges" in designing with reusable building elements (Gorgolewski, 2008). This thesis has reframed such challenges as information problems to shift the focus from problems to (directions for) solutions. A resulting key insight for design management is that previous demolition information can be used to close material loops. A serious gaming approach was adopted to make the impacts of design decisions experientially available (Chapter 6) - and reinterpreted for the context of circular building projects, as discussed below. From this, it is argued here that design managers can use demolition information, like (uncertain) lead times, sales prices and availability of materials, to 'optimize' a design proposal for reuse. Chapter 2 strengthens this insight with real-world evidence about demolition contractors' production of similar demolition information. The type of information originates from any building that is (partly) being demolished before the construction of a new one and is, accordingly, referred to as a priori demolition information. Another key insight of this thesis relates to the use of (what is here called) a posteriori demolition information, which originates from a later demolition life-cycle stage. Where previous studies introduced the concept of design for disassembly (Crowther, 1999; Durmisevic, 2006), this thesis took a next step by linking it with BIM-based methods and illustrating the managerial implications with empirical evidence. Design managers can anticipate future reuse through using (ease of) demolition information in the reversible building design process (Chapter 4). A design proposal can be improved further through incorporating feedback of building owners/clients, for example about potential future transformations, which can be captured with a virtual reality-based method (Chapter 5). Although reviews may not specifically deal with demolition information, it is argued here that they are particularly relevant for circular design projects as they contribute to material reductions through optimizing a design proposal and solving any errors. The specific knowledge outputs related to the two key design management contributions are further elaborated below. 


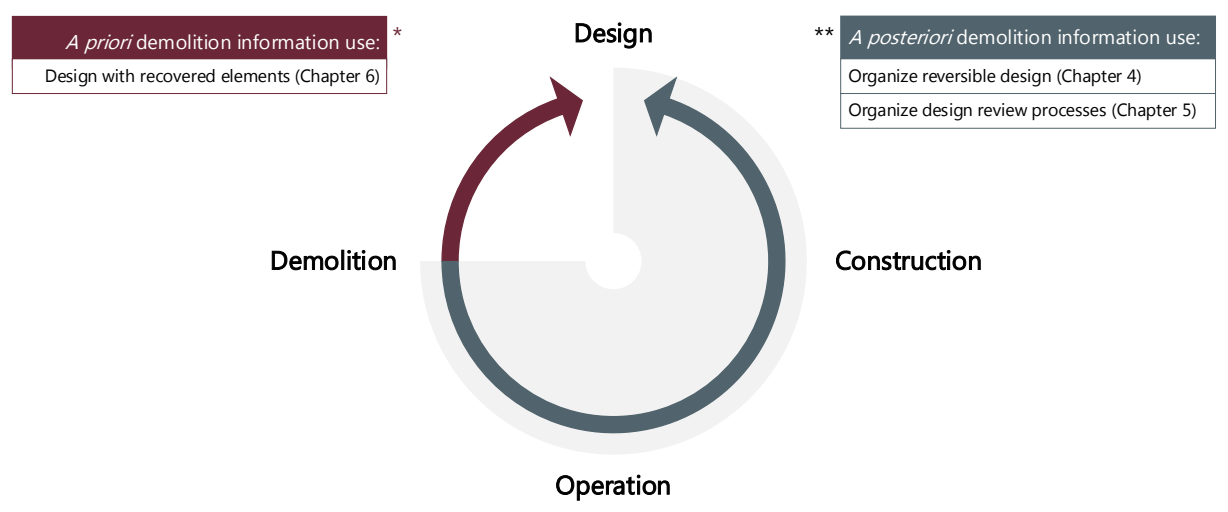

Figure 19: Design managers can keep building materials in the loop through leveraging a priori and a posteriori demolition information

* $A$ priori demolition information concerns any specifications and representations of reusable building materials

** A posteriori demolition information concerns any plans to facilitate recovery and subsequent reuse (or recycling) of materials in the future

\section{BIM uses for reversible building design}

The fourth chapter identified, classified and elaborated on BIM uses for reversible building design. Seen as a necessary (yet not sufficient) step towards a circular built environment, this study defines a reversible building as a type of building that is specifically designed to enable transformations, disassembly and reuse of elements. This implies the use of (ease of) demolition information to generate a reversible building design proposal. Previous studies (e.g. Durmisevic, 2006) have not yet explored the potentials of BIM to support design practices that specifically focus on these types of buildings. A literature review on BIM uses was therefore conducted, followed by an in-depth case study of the reversible building design practices of a system builder.

Eight BIM uses identified in recent literature were compared with actual implementations for reversible building design. The chapter provided qualitative, in-depth insights into the uses of BIM and their perceived benefits. Based on the extent to which they supported reversible design practices (fully, partially or deficiently) in the focal case, we classified the eight as either 'key', 'viable' or 'negligible' BIM uses. As such, three key BIM uses for reversible building design are: design authoring, 3D coordination (clash detection) and drawing production. Two viable BIM uses for reversible building design are: quantity take-off (cost estimation) and design review. The last three negligible BIM uses for reversible building design are: phase planning (4D simulation), code validation and engineering analyses. 
The study contributes insights on the potentials to leverage BIM for reversible buildings. Despite the inherent drawbacks of a single case study, we have argued that these insights are theoretically relevant as they deal with a "unique" (Yin, 2009) phenomenon. That is, it is (still) uncommon to design buildings in ways that allow easy transformations, disassembly and reuse of elements in the future. The study's attempts to identify, classify and elaborate on BIM uses hence particularly help in better understanding the role of BIM in reversible design practices. The main contribution here is our discussion about what works and why. Regarding design authoring, the study also zooms in on the system builder's implementation and interpretation of (earlier developed) design for disassembly guidelines in practice.

The main contribution of Chapter 4 is thus that BIM can support reversible building design, but that some uses have greater potential than others.

\section{Systematic reflection on pre-meeting virtual reality environments for design review}

The fifth chapter proposes pre-meeting virtual reality environments to communicate design intent and feedback. Where the previous study dealt with generating reversible building design solutions, this study argues that those solutions must be evaluated to manage expectations between designers and clients. A literature review (e.g. Shen et al., 2013; J. Wang et al., 2014; Woksepp $\&$ Olofsson, 2008) suggested that those design reviews are often supported with traditional visualizations with limited information transferability and that meeting dynamics may limit the involvement of individuals, which may then result in biased feedback.

As a potential solution, we examined how pre-meeting virtual environments could support design reviews. A prototypical virtual environment was developed that allowed individual clients (or their representatives) to navigate through and comment on a design proposal. This tool was used before, as a preparation of, a designer-client review meeting. A pattern-matching method (Trochim, 1989; Yin, 2009) applied to two real-world design projects revealed that 'theoretical expectations' and 'pragmatic realities' matched (yet in varying degrees) regarding three themes: explorations from a user perspective, participation in solution-finding and feedback on a design proposal.

This systematic reflection on the proposed method is the chapter's main contribution. Even though the study does not specifically target reversible or circular design proposals, it is argued here that circular design processes may particularly benefit from the study's insights: improved designer-client 
information flows can reduce material usage/waste by timely solving errors and optimizing a design proposal. Moreover, the need to generate design information that can survive until a circular building's deconstruction creates more potential for accurate representations within virtual environments. The study finally also contributes to the call of Kim et al. (2013) for more empirical reflections about virtual reality potentials.

The main contribution of Chapter 5 is thus that virtual reality environments provide benefits when used prior to designer-client review meetings in terms of: (1) exploration from a user perspective; (2) participation in solution-finding; and (3) feedback on a design proposal.

\section{A serious gaming approach for construction supply chain management}

The sixth chapter describes a serious gaming approach to experientially learn about the impacts of design decisions on later life-cycle stages. A literature review suggested that practically applicable knowledge about how to improve the performance of construction supply chains is difficult to acquire (e.g. Peterson et al., 2011). This seems particularly relevant for circular supply chains, because documented reflections about those are very scarce. We noticed that there are numerous supply chain management serious games and also construction management games, but not on the combination. We thus designed a construction supply chain management serious game using the Triadic Game Design approach (Harteveld, 2011), organized game play sessions with students and used a content analysis method to evaluate their written reflections.

The serious game enabled players to experientially learn about construction supply chain management. The one-player board game challenges players to design, purchase and construct a tower with Lego bricks. Serious games, like this one, can provide a meaningful experience about improving the performance of a supply chain by: (1) coordinating design and construction coherently; (2) taking constructability aspects into account when designing, and (3) continuously balancing scope, time and cost throughout a project. The game thereby allows to understand how designing, purchasing and constructing (as distinct managerial activities) interact with each other. Meaningful experiences (like in the developed game) help to reflect - and better understand - the impacts of design decisions.

The study contributes both to serious gaming and construction supply chain management literature. I documented how we designed, implemented and reflected on a serious game, whereas previous studies often focused on only one 192 | Discussion 
of those steps (see e.g. Rüppel \& Schatz, 2011). In hindsight, I argue that some of the game design choices, such as a scarcity of materials and uncertainties regarding timely deliveries, correspond better with situations in which a demolition contractor acts as a supplier. That would imply a game setting in which the focal company (that the player manages) uses information of reusable building materials to generate a design, purchases those materials and then builds a tower with (only) recovered materials. Such a reframing would suggest that serious games can also enable to learn about managing circular supply chains.

The main contribution of Chapter 6 is thus that serious games can contribute in experiential learning about construction supply chain management and, in particular, the impacts of (circular) design decisions on later life-cycle stages.

\section{Practical contributions}

This thesis has systematically developed a knowledge base that can guide practitioners in managing circular building projects. Practitioners need to gather, interpret and synthesize information to initiate and control closed-loop material flows. Practical consequences can be derived from the main theoretical insights for demolition and design managers aiming to reduce, reuse and recycling building materials. Demolition managers need to use a priori and a posteriori design information; design managers require a prioriand a posteriori demolition information. For both types of managers, information from previous and later life-cycle stages is relevant to effectively close material loops: they need to look backwards and forwards. Today's building projects, also pioneering 'circular' ones (see e.g. Appendix II), frequently focus on processing either one of the two types of information. For example, new buildings may be designed for disassembly (i.e. through using a posteriori demolition information), but only use new and no recovered materials (i.e. without using a priori demolition information). Or recovered building elements are online offered for sale (i.e. by using a posteriori design information), but without any quality guarantees (i.e. without a priori design information). The main practical insight that can be derived from this thesis is, accordingly, that managers of circular building projects need to deal with uncertainties from the past and anticipate developments in the future. This is further elaborated below for each chapter separately.

The first chapter's insight that demolition contractors' recovery decisions depend on three general conditions provides a strong basis to develop strategies for promoting object recovery. I argue that the supply of reusable building objects is governed by a set of rules that this research uncovered. That is, a demolition 
contractor will recover any building object when it (i) identifies an economic demand, (ii) distinguishes disassembly routines, and (iii) can control the future performance. Objects will not be recovered for reuse when one or more of those three conditions is not satisfied. Understanding how the demolition contractor makes such recovery decisions can be of great help in promoting recovery and reuse practices, for example when formulating material efficiency policies. If one wants to stimulate object recovery, then strategies must be deployed that make it more likely that the three conditions will be satisfied. The study, accordingly, provided hands-on examples for strategies that can be readily adopted by manufacturers, designers/architects, builders, building owners and (also) demolition contractors.

Our second study's conceptualization of different types of demolition projects can guide demolition contractors, and their upstream and downstream supply chain partners, in adopting coordination mechanisms. The research suggests that firms active during the end-of-life phase, in particular demolition contractors, need to deal with three major sources of uncertainty: building, workflow and environmental uncertainty. The research argues that coordination efforts are effective when there is a "match" between information processing capacity and information processing needs. In that line, I suggest that demolition contractors need to become more aware of the specific levels of uncertainty in their projects and that they then respond accordingly. The conceptualization can guide them in selecting, implementing and reflecting on those responses. To illustrate this, mechanisms were derived with which an ineffective demolition contractor could better align its information processing capacity with the experienced levels of uncertainty. I also argue that our characterization of the three demolition contractors studied as 'separator', 'mover' or 'salesman' helps in understanding differences in the organizational design of these types of firms and the specific (information processing) needs.

The ethnographic-action insights of the third chapter help in understanding how information is used during deconstruction projects and how BIM-based methods can support that. The paper is one of the first to introduce BIM during site-based deconstruction practices. The systematic reflections on three BIM uses can guide demolition contractors in the potential value of BIM for their projects. Where the IT paradigm has gained significant momentum in many other construction firms, like general contractors and design/engineering firms, BIM has not propagated throughout the life-cycle of buildings. The exploratory and emergent research hence adopted an ethnographic-action research approach to iteratively develop three (new) BIM uses: (I) 3D existing conditions analysis, (II) reusable elements labeling, and (III) 4D deconstruction simulation. This gives demolition contractors entirely new opportunities to process information during their site activities. 
Through presenting information as an important contingency for on-site deconstruction practices, the research finally informs other (types of firms) along the supply chain about the potential benefits of maintaining and updating accurate (as-built) information throughout a building's life-cycle.

The fourth chapter contributes insights about BIM uses for reversible building design. The study first provides an overview of eight different BIM uses and their theoretical benefits. This overview in itself can help practitioners to better understand the potentials of BIM for (design) project management. In the study, we bring this overview a step further by contrasting it with actual implementations of BIM for designing reversible buildings. Given that still relatively few buildings are designed as reversible structures, I argued that practitioners may also benefit from those documented examples. For each BIM use, we elaborated to what extent its implementation supported the firm's reversible building design process. A classification was subsequently made between 'key', 'viable' and 'negligible' BIM uses. Designers, who aim to create reversible buildings, can expect similar benefits as the ones we described when the contexts of their works are similar to ours. The classification and our elaborations hence suggest a relative order of potentials of implementing BIM for reversible building design. That is, practitioners are recommended first to select the key BIM uses (design authoring, 3D coordination and drawing production), followed by the viable ones (quantity take-off and design review). The potentials of the negligible BIM uses (phase planning, code validation and engineering analyses) remain unclear.

The fifth chapter's pattern-matching insights provide a deeper understanding of pre-meeting virtual reality environments for design review. Where the previous study focused on generating design proposals, this one deals with evaluating them. In the study, we propose a new method to communicate design intent and subsequent feedback between designers and clients/building owners. This method involves the individual use of a virtual environment before a designerclient review meeting. To that end, I used a game engine to program a prototypical tool that runs on a laptop with average processing power and does not (necessarily) require any head-mounted device ${ }^{1}$. It allows a client to virtually navigate through a (design) model from a first-person point of view and to leave textual feedback in the model. The feedback, screenshots and object data are stored - and can be used by designers. I demonstrated the method through importing the 3D design representations of two actual projects in the tool and inviting eight clients (or their representatives) to evaluate the designs. A pattern-

${ }^{1}$ Source code is available at: github.com/MCvdBerg/designreview 
matching strategy was used to compare the observed 'pragmatic realities' of this method with expected 'theoretical ideals' - revealing deep insights in how it works and why. The method can provide benefits related to: (i) explorations from a user perspective, (ii) participation in solution-finding and (iii) feedback on a design proposal. These benefits come at the expense of extra time needed for setting up a navigable environment and organizing individual reviews though. The insights help designers and clients to make a more informed choice about whether (or not) to support their design reviews with (pre-meeting) virtual environments.

The serious gaming approach presented in the sixth chapter provides new ways to acquire experience in coordinating (circular) construction supply chain activities. This study describes how a new serious game, called Tower of Infinity, was developed through balancing the conceptual "worlds" of Reality, Meaning and Play (Harteveld, 2011). The serious game in itself is a major outcome of this research. Of particular interest is the underlying game concept to expose the interactions between different project life-cycle phases, since those are traditionally dominated by distinct organizations that aim to optimize their own project activities rather than those of the entire supply chain. Using data from game sessions with 64 students, we showed how the focal serious game enabled their players to improve the performance of a construction supply chain. Such practically applicable knowledge is difficult to teach with alternative basic assignments or thick stories of best practices; educators may benefit from our reflection on this new teaching opportunity for construction supply chain management. The serious gaming approach, hence, assists in better understanding the impacts of one organization's decisions on other stages of the life-cycle. This is, in hindsight, a crucial step towards circular construction supply chains, since closing the gap between demolition and design can greatly benefit from people's (learning) experience in connecting otherwise separate life-cycle stages.

\section{Limitations}

This research provides relevant scientific and practical contributions for circular building management. However, there is still a long way to go in the transition to a complete regenerative and restorative built environment. This research could only investigate and provide guidance for some of the most pertinent management issues in connecting building demolition and design. Here, I acknowledge the most important overall limitations of this thesis:

- The thesis is limited to building projects. The introduction section of this thesis has outlined some significant problems caused by the construction industry; the other parts explored some directions for solutions. The findings presented 
in those parts are, however, foremost applicable to building projects and it is unclear to what extent they may be generalized to other types of construction projects (e.g. roads, dikes, bridges, viaducts, pipes or cables). For example, the reuse potential of certain materials may differ per project type, because infrastructure assets are generally demolished at the end of their technicallife, but buildings at the end of their use life-cycle.

- The research has focused on just two life-cycle phases. The thesis tried to find connections between demolition and design (management). The stages of construction and operation have, therefore, received very little attention even though I have emphasized the importance of whole life-cycle approaches. Different building layers are typically associated with different life-cycles. The implications of different rates of change bring additional complexities during construction and operation stages that this research has only partly covered.

- The thesis has paid little attention to interactions between projects. In line with the above, the strong focus on information usages and models in distinct projects has downplayed the role of information sharing and collaboration modes beyond project levels. Information platforms, such as the online marketplace discussed in Chapter 2, are necessary to organize reuse of materials on a larger scale. The relations between different projects and the needs for interorganizational information models are, however, only partly discussed.

- Two chapters were reinterpreted for the context of circular building projects. Chapter 5 and 6 represent studies that dealt with research questions without (explicit) connection to circular economy and/or sustainability literature. I reinterpreted the main insights from these studies to align them with the other chapters. Although I outlined the arguments to do so, the reinterpretations may have overlooked or simplified some details that are (only) relevant for projects that are concerned with buildings in which circularity thinking is applied.

- The research has overlooked energy flows. The chapters dealt primarily with material flows and the role of (digital) information to support those flows. This is in line with one key principle of circular economies: the idea to recirculate materials for as long as possible. However, another key characteristic is the transition towards the use of renewable energy. Apart from discussions about the embodied energy of building objects, this research has ignored energy efficiency issues. It seems that material savings indirectly contribute to energy savings (due to lower production rates), but more detailed research into the specific interactions is necessary.

- The research only dealt with projects in the Netherlands. The country seems well suited for circular economy research. Practically, it has limited natural resources and is an international frontrunner regarding recycling practices (Gálvez-Martos et al., 2018), while scientifically, it produced some highly 
influential conceptual frameworks for sustainability (see e.g. Lansink, 2017). I think that some of the studied projects can serve as powerful 'best practice' examples, but the generalizability may be limited given the absence of projects in other countries.

Other limitations belong to the respective chapters and are discussed there. Despite the limitations, the thesis brings forth a number of stepping stones for moving towards a circular built environment. 


\section{Conclusions}




\section{Conclusions}

This thesis developed actionable knowledge to manage circular building projects. In recent years, the scientific and practical needs for such a knowledge base have become increasingly clear with growing awareness about the significant waste volumes, pressures on natural resources and associated social problems caused by the construction industry. Fundamental changes to ingrained construction practices are intended with the adoption of the circular economy concept. To that end, previous chapters explored how construction managers can use information to reduce, reuse and/or recycle building materials. As elaborated below, it is concluded that there are two key strategies to achieve closed-loop material flows: leveraging information potentials during the building life-cycle stages of demolition and of design.

\section{Demolition management for closing material loops}

To close material loops, demolition activities must be managed with information from both previous and later design stages. Demolition is traditionally seen as the last phase of a building's life-cycle. Its typical management challenge is to efficiently reduce any building (parts) to waste, which is recycled at best. But in a circular economy, salvaged buildings are sources of valuable materials and the challenge during demolition is to recover those in a process sometimes also called "harvesting" or "urban mining" (Koutamanis et al., 2018) and to direct them to new sites. Demolition managers appear to decide about the fate of any object of a building based on three - implicit - rules. Using ethnographic data, Chapter 1 poses that any building object will only be recovered for reuse if the demolition contractor (1) identifies an economic demand, (2) distinguishes disassembly routines and (3) can control the future performance. If one or more of these conditions is not met, an object will be treated as waste. Projects in which many building objects are recovered thereby require different organizational design choices. Previous reports already speculated that other types of business models would be necessary (Thelen et al., 2018). Chapter 2 used a multiple-case study to explain that, depending on recovery and reuse ambitions, demolition contractors need to "process" (Galbraith, 1973, 1974) different amounts of information due to building, workflow and environmental uncertainties. The metaphors of a 'separator', 'mover' and 'salesman' were, accordingly, proposed to label and distinguish between different organizational designs. The chapter also revealed that demolition contractors, even the rather innovative 'mover' and 'salesman' firms, heavily relied on traditional, paper-based methods to coordinate demolition activities. Chapter 3 used an ethnographic-action approach to replace some of those with BIM-based methods and, as such, responded to the lack of $200 \mid$ Conclusions 
studies on BIM for existing buildings (Volk et al., 2014). Three newly developed uses of BIM appeared to have potential to support site-based practices: 3D existing conditions analysis, reusable elements labeling and 4D deconstruction simulation. Taken together, these studies provided detailed insights about the use of information for demolition management activities. A priori design information can be used to determine what objects a building constitutes of (Chapter 2), to estimate whether those can be disassembled properly or not (Chapter 1 ) and to improve the efficiency of demolition activities (Chapter 3). $A$ posteriori design information can be used to assess the economic demand for building objects (Chapter 1), to reduce environmental uncertainty (Chapter 2) and to label reusable elements according to the needs in other projects (Chapter 3). Hence, demolition managers can enable closed-loop material flows through leveraging the potentials of a priori and a posteriori design information.

\section{Design management for closing material loops}

To close material loops, design activities must also be managed with information from both previous and later demolition stages. The act of designing has often been described as a problem-solving process in which designers "inevitably and instinctively prefigure solutions to the problems they are confronted with" (Ching, 2014). This process is managed to ensure that design solutions comply with client needs and wishes - at least, those for the near future. The designs of circular buildings also allow for later building transformations, including complete (selective) demolition, that may be inherently uncertain. A circular building is foremost reversible in that building parts can be transformed, disassembled and - ultimately - reused. Previous works developed (conceptual) "design for disassembly" guidelines (Crowther, 1999, 2018; Durmisevic, 2006). Chapter 4 extends those works with (empirical) insights about the potential of BIM technologies to support reversible building design. The case study concludes that design authoring, 3D coordination (clash detection) and drawing production are the three most effective design management methods in that regard. Designing buildings as reversible structures, with (or without) these methods, makes it more likely that material loops will be closed in the future. Evaluation of a design proposal to detect any errors can, in its turn, reduce material usage. Organizing design review meetings enables communicating design intent and feedback between designers and clients. The multiple-case study of Chapter 5 demonstrated that deploying virtual reality tools before such meetings can thereby provide benefits regarding exploration from a user perspective, participation in solution-finding and feedback on a design proposal. Redesign activities after the virtual experience, as provided by the focal tool, can 
then lead to an improved design proposal and, ultimately, reduce material use. An alternative approach is proposed in Chapter 6. Starting from the point that it is difficult to acquire experience in managing construction supply chains, this chapter presented a low-tech serious game about the interactions between purchasing, design and construction activities. After reinterpreting the original in-game 'suppliers' as 'demolition contractors' (given the scarcity of materials and uncertain deliveries), it can be concluded that such serious games enable experiential learning about the impacts of (circular) design decisions. Altogether, these studies demonstrate how design management depends on both a priori and a posteriori demolition information to close material loops. As for the first, demolition information about (uncertain) lead times, sales prices and availability of materials can be used to generate a design proposal with reused elements (Chapter 6). As for the latter, design managers can ease future reuse through organizing the generation of reversible building design proposals with BIMbased methods (Chapter 4) and can reduce material usage with virtual realitybased design reviews that aim to solve any design issues in time (Chapter 5). Design managers can thus enable closed-loop material flows through leveraging the potentials of a priori and a posteriori demolition information.

\section{Outlook and recommendations}

Managing circular building projects involves organizing demolition and design information to initiate and control material reduce, reuse and/or recycle activities. The transition to a circular built environment necessitates rethinking project management practices, in particular for demolition and design. Demolition must no longer be seen as the last life-cycle stage and design not as the first. In circular building projects, alternatively, both stages are part of a continuous cycle centered around "buildings as material banks" (see e.g. Debacker \& Manshoven, 2016). This approach acknowledges that different materials have their own specific life-cycles and "all interact dynamically in space and time" (Pomponi \& Moncaster, 2017). In the same line, the 'building' must be seen as a flexible structure that keeps responding to changing user needs through structural, spatial and material transformations (Durmisevic, 2006). Changes, both the smaller and larger ones, are no longer prevented but facilitated as such buildings are allowed to "learn" (Brand, 1994). This conceptualization implies that the boundaries of a building project are likely to blur. The key (project) management challenge is nonetheless to close material loops through "a combination of reduce, reuse and recycle activities" (Kirchherr et al., 2017). To that end, the main actionable knowledge that this thesis developed is that circular building projects can be managed through leveraging 
the potentials of previous and later design information during demolition lifecycle stages (respectively demolition information during design). This provides a base for the following (research) recommendations:

- Investigate new ways to keep information in the loop. Through adopting several methodologies, this thesis has demonstrated that information is essential to close material flows. Chapter 4 discussed how BIM-based methods can be used to design reversible buildings. The information generated during that phase is also relevant - again - during demolition. Chapter 2 illustrated this with information about building connections, which demolition managers use to assess a building's disassemble-ability. The design and demolition lifecycle phases are usually dominated by separate firms with different working practices, resources and objectives: a recipe for barriers to interorganizational information sharing and collaboration (Adriaanse et al., 2010a; Adriaanse, Voordijk, \& Dewulf, 2010b). Given such barriers on one hand and the importance of information on the other, a logical next research question is then how information can be created, maintained and shared throughout the different life-cycles of a building project efficiently. As an example, the concept of material passports, described as sets of data about materials characteristics (Luscuere, 2017), may help to keep track of the material composition of building objects over different cycles of disassembly and reuse. New data structures, standardized templates and file exchange formats are required to fit (information) needs of the present and the future. Such research is essential to better organize closed-loop material flows.

- Study demolition practices in context. While this thesis discussed that reversible building design facilitates closing material loops, those loops are only actually closed during disassembly and reuse (if at all). This then requires understanding the asset and its context. "Unlike the initial phases of design and construction (which fill most of the shelves of architectural libraries)", however, the demolition life-cycle phase has received relatively little scientific attention (Thomsen et al., 2011). It is therefore suggested that more research should be devoted to understanding demolition activities in their specific contexts, like a significant part of this thesis did. This is particularly justified by the insight of Chapter 1 that salvaged buildings can be sources of valuable materials and that it is up to demolition contractors to recover those. Chapter 3 furthermore opened up completely new lines of research through suggesting that BIM-based methods can provide benefits during (rather than merely before) demolition activities. Demolition is thus another key application area that leading BIM researchers have overlooked (cf. Eastman et al., 2011; Turk, 2016). Demolition studies will become increasingly important due to (expected) policies that promote material recovery and reuse. Future studies are recommended into issues of existing conditions modeling, site 
layout and transportation planning. Similar to Chapter 3, these studies must thereby explore (new) digital possibilities offered by BIM technologies.

- Develop a measurement instrument to assess 'circularity' in building projects.

The idea of a circular economy has been popularized by policy-makers, business leaders and academics as a likely pathway to sustainable growth and development. These actors have different perspectives on the concept (and how to measure it) - as I have also noticed during several conferences and business meetings on the topic. These differences make it difficult to meaningfully compare building project alternatives. Some of the projects in this thesis, for example, have been referred to as 'best practices', implying that they are (very) 'circular', but this could not be substantiated with a numerical score. A measurement instrument is thus proposed that can indicate the extent to which a building project is actually regenerative with regard to material and energy consumption. Such an instrument must comply with BIM and not be limited to future reuse/transformation potential of new materials, but also include existing ones. The basic Circular Project Model presented in Figure I (Appendix II) could provide a base for such an instrument. Other potential starting points for (further) development are BIM tools focused on disassembly (Akinade et al., 2015; Akinade, Oyedele, Omoteso, et al., 2017) and the general Material Circularity Indicator (Ellen MacArthur Foundation \& Granta Design, 2015).

- Explore logistics opportunities for scaling up circular building efforts. A key problem in closing material loops is to connect supply and demand (Cooper \& Gutowski, 2015). With an information perspective on the interplay between these two, this thesis has reinforced the insight that this is essentially a logistics problem. Reverse logistics, which is concerned with material flows from the point of consumption to the point of origin (Rogers \& Tibben-Lembke, 1999), is a relatively settled field in manufacturing industries, but not in construction (Hosseini et al., 2014; Hosseini et al., 2015). Chapter 2, however, discussed how storage facilities and online marketplaces could be employed to organize reverse logistics processes. To scale up circular building efforts, the potential of these and other logistics opportunities must be studied in more detail. Research is therefore necessary that links project management with trading platforms and asset management.

- Design solutions to experience circular building projects. Because fundamental changes to project management practices are necessary to close material loops and documented real-world examples are still limited, new opportunities for learning must be created. Chapter 6 argued that experiential learning is a powerful way to acquire (new) knowledge. Chapter 5 similarly provided evidence of potential benefits from a virtual experience. Along the same lines, it is recommended to design experiential solutions for circular building management. These could include additions to this thesis' serious game (e.g. extra levels) - for example by adding demolition constraints, 
connecting material with energy flows or integrating urban planning issues. New serious games are also highly encouraged. To enable learning-by-doing in the real world, pilot projects and small circularity interventions are recommended. Project teams could, for example, commit themselves to deliver a 'circular' solution for only one building part - and then actively experiment with and reflect on that solution's implications for a process redesign, supply chain responsibilities and business and ownership models. Such research and development strategies provide opportunities to gain experience in circular working practices, but limit any (financial) risks.

To conclude, this paper-based thesis has provided some guidance for rethinking the way building projects are to be managed. Material reduce, reuse and recycle activities are essential steps to move towards a healthier built environment that can regenerate itself time after time. It is concluded that those activities can be managed through leveraging information potentials during demolition and design life-cycle stages. In circular building projects, this thesis posed that those stages are part of a continuous cycle. The chapters demonstrated, accordingly, that there are two key strategies to achieve closed-loop material flows. Demolition managers need to leverage information from previous and later design stages (i.e. a priori and a posteriori design information); design managers similarly need to leverage information from previous and later demolition stages (i.e. a prioriand a posteriori demolition information). These key strategies provide a hopeful and actionable response to many of the socio-environmental problems caused by the construction industry. 


\section{References}




\section{References}

Adams, K. T., Osmani, M., Thorpe, T., \& Thornback, J. (2017). Circular economy in construction: current awareness, challenges and enablers. Proceedings of the Institution of Civil Engineers - Waste and Resource Management, 170(1), 15-24.

Adriaanse, A. M., Voordijk, J. T., \& Dewulf, G. P. M. R. (2010a). Adoption and use of interorganizational ICT in a construction project. Journal of Construction Engineering and Management, 136(9), 1003-1014.

Adriaanse, A. M., Voordijk, J. T., \& Dewulf, G. P. M. R. (2010b). The use of interorganisational ICT in construction projects: A critical perspective. Construction Innovation, 10(2), 223-237.

Agrawal, S., Singh, R. K., \& Murtaza, Q. (2015). A literature review and perspectives in reverse logistics. Resources, Conservation and Recycling, 97, 76-92.

Akanbi, L. A., Oyedele, L. O., Akinade, O. O., Ajayi, A. O., Davila Delgado, M., Bilal, M., \& Bello, S. A. (2018). Salvaging building materials in a circular economy: A BIMbased whole-life performance estimator. Resources, Conservation and Recycling, 129, 175-186.

Akbarnezhad, A., Ong, K. C. G., \& Chandra, L. R. (2014). Economic and environmental assessment of deconstruction strategies using Building Information Modeling. Automation in Construction, 37, 131-144.

Akinade, O. O., Oyedele, L. O., Ajayi, S. O., Bilal, M., Alaka, H. A., Owolabi, H. A., . . Kadiri, K. O. (2017). Design for Deconstruction (DfD): Critical success factors for diverting end-of-life waste from landfills. Waste Management, 60, 3-13.

Akinade, O. O., Oyedele, L. O., Bilal, M., Ajayi, S. O., Owolabi, H. A., Alaka, H. A., \& Bello, S. A. (2015). Waste minimisation through deconstruction: A BIM based Deconstructability Assessment Score (BIM-DAS). Resources, Conservation and Recycling, 105, 167-176.

Akinade, O. O., Oyedele, L. O., Omoteso, K., Ajayi, S. O., Bilal, M., Owolabi, H. A., ... Henry Looney, J. (2017). BIM-based deconstruction tool: Towards essential functionalities. International Journal of Sustainable Built Environment, 6(1), 260 271.

Al-Jibouri, S. H., \& Mawdesley, M. J. (2001). Design and experience with a computer game for teaching construction project planning and control. Engineering, Construction and Architectural Management, 8(5-6), 418-427.

Albert, A., Hallowell, M. R., Kleiner, B., Chen, A., \& Golparvar-Fard, M. (2014). Enhancing construction hazard recognition with high-fidelity augmented virtuality. Journal of Construction Engineering and Management, 140(7), 04014024.

Allwood, J. M. (2014). Squaring the circular economy: The role of recycling within a hierarchy of material management strategies. In E. Worrell \& M. A. Reuter (Eds.), Handbook of Recycling (pp. 445-477). Boston: Elsevier.

Allwood, J. M., Ashby, M. F., Gutowski, T. G., \& Worrell, E. (2011). Material efficiency: A white paper. Resources, Conservation and Recycling, 55(3), 362-381.

Alsafouri, S., \& Ayer, S. K. (2018). Review of ICT implementations for facilitating information flow between virtual models and construction project sites. Automation in Construction, 86, 176-189. 
Andrews, D. (2015). The circular economy, design thinking and education for sustainability. Local Economy, 30(3), 305-315.

Anil, E. B., Tang, P., Akinci, B., \& Huber, D. (2013). Deviation analysis method for the assessment of the quality of the as-is Building Information Models generated from point cloud data. Automation in Construction, 35(Supplement C), 507-516.

Archer, M. S. (1995). Realist social theory: The morphogenetic approach. Cambridge: Cambridge University Press.

Arunachalam, R., \& Sadeh, N. M. (2005). The supply chain trading agent competition. Electronic Commerce Research and Applications, 4(1), 66-84.

Azhar, S. (2011). Building Information Modeling (BIM): Trends, Benefits, Risks, and Challenges for the AEC Industry. Leadership and Management in Engineering, 11(3), 241-252.

Azhar, S., Ahmad, I., \& Sein, M. K. (2009). Action research as a proactive research method for construction engineering and management. Journal of Construction Engineering and Management, 136(1), 87-98.

Bak, O., \& Boulocher-Passet, V. (2013). Connecting industry and supply chain management education: exploring challenges faced in a SCM consultancy module. Supply Chain Management: An International Journal, 18(4), 468-479.

Bankvall, L., Bygballe, L. E., Dubois, A., \& Jahre, M. (2010). Interdependence in supply chains and projects in construction. Supply Chain Management: An International Journal, 15(5), 385-393.

Barlish, K., \& Sullivan, K. (2012). How to measure the benefits of BIM - A case study approach. Automation in Construction, 24(0), 149-159.

Bassanino, M., Fernando, T., \& Wu, K. C. (2014). Can virtual workspaces enhance team communication and collaboration in design review meetings? Architectural Engineering and Design Management, 10(3-4), 200-217.

Bassanino, M., Wu, K. C., Yao, J., Khosrowshahi, F., Fernando, T., \& Skjærbæk, J. (2010). The impact of immersive virtual reality on visualisation for a design review in construction. Paper presented at the Information Visualisation (IV), 2010 14th International Conference.

Battini, D., Faccio, M., Persona, A., \& Sgarbossa, F. (2009). Logistic Game ${ }^{\mathrm{TM}}$ : learning by doing and knowledge-sharing. Production Planning \& Control, 20(8), 724-736.

Bellotti, F., Kapralos, B., Lee, K., Moreno-Ger, P., \& Berta, R. (2013). Assessment in and of Serious Games: An Overview. Advances in Human-Computer Interaction, 2013, 1-11.

Bemelmans, J., Voordijk, J. T., \& Vos, B. (2012). Supplier-contractor collaboration in the construction industry. Engineering, Construction and Architectural Management, 19(4), 342-368.

Bensaou, M. (1999). Portfolios of buyer-supplier relationships. MIT Sloan Management Review, 40(4), 35.

Bensaou, M., \& Venkatraman, N. (1995). Configurations of Interorganizational Relationships: A Comparison between U.S. and Japanese Automakers. Management science, 41(9), 1471-1492. 
Bensaou, M., \& Venkatraman, N. (1996). Inter-organizational relationships and information technology: A conceptual synthesis and a research framework. European Journal of Information Systems, 5(2), 84-91.

Benyus, J. M. (1997). Biomimicry: Innovation inspired by nature. New York, NY: HarperCollins.

Bernard, H. R., \& Ryan, G. W. (2010). Analyzing qualitative data: Systematic approaches. Thousand Oaks, CA: SAGE publications.

Bhaskar, R. (2009). Scientific Realism and Human Emancipation. London: Routledge.

Binder, T., De Michelis, G., Ehn, P., Jacucci, G., Linde, P., \& Wagner, I. (2011). Design things. MIT press.

Björgvinsson, E., Ehn, P., \& Hillgren, P. A. (2012). Design Things and design thinking: Contemporary participatory design challenges. Design Issues, 28(3), 101-116.

Boeije, H. (2009). Analysis in qualitative research. London: Sage publications.

Borren, B. (2016, October 19). 'Flexibel' schoolgebouw 4e Gymnasium alsnog gesloopt. Het Parool. Retrieved from https://www.parool.nl/amsterdam/-flexibelschoolgebouw-4e-gymnasium-alsnog-gesloopt a4398764/

Bouchlaghem, D., Shang, H., Whyte, J., \& Ganah, A. (2005). Visualisation in architecture, engineering and construction (AEC). Automation in Construction, 14(3), 287-295.

Boulding, K. E. (1966). The economics of the coming spaceship earth. New York.

Bowman, D. A., Koller, D., \& Hodges, L. F. (1997). Travel in immersive virtual environments: An evaluation of viewpoint motion control techniques. Paper presented at the Virtual Reality Annual International Symposium, 1997., IEEE 1997.

Brand, S. (1994). How buildings learn: What happens after they're built. New York: Penguin. Brundtland, G., Khalid, M., Agnelli, S., Al-Athel, S., Chidzero, B., Fadika, L., . . Okita, S. (1987). Our Common Future ('Brundtland report'): Oxford University Press, USA.

Bryde, D., Broquetas, M., \& Volm, J. M. (2013). The project benefits of Building Information Modelling (BIM). International Journal of Project Management, 31(7), 971-980.

Busse, C., Meinlschmidt, J., \& Foerstl, K. (2016). Managing information processing needs in global supply chains: A prerequisite to sustainable supply chain management. Journal of Supply Chain Management, 53(1), 87-113.

Callon, M., Lascoumes, P., \& Barthe, Y. (2009). Acting in an uncertain world: An essay on technical democracy. Cambridge, Massachusetts: The MIT Press.

Cao, G., Clarke, S., \& Lehaney, B. (2004). The need for a systemic approach to change management-a case study. Systemic Practice and Action Research, 17(2), 103126.

Cárcamo, J. G., Trefftz, H., Acosta, D. A., \& Botero, L. F. (2014). Collaborative design model review tool for the AEC industry. Paper presented at the 2014 Virtual Concept International Workshop, Medellin, Colombia.

Castronovo, F., Nikolic, D., Liu, Y., \& Messner, J. (2013, 30-31 October 2013). An evaluation of immersive virtual reality systems for design reviews. Paper presented at the 13th International Conference on Construction Applications of Virtual Reality, London, UK.

Cha, H. S., Kim, K. H., \& Kim, C. K. (2011). Case study on selective demolition method for refurbishing deteriorated residential apartments. Journal of Construction Engineering and Management, 138(2), 294-303. 
Chang, A. S. (2001). Work-time model for engineers. Journal of Construction Engineering and Management, 127(2), 163-172.

Chang, A. S., \& Tien, C. C. (2006). Quantifying uncertainty and equivocality in engineering projects. Construction Management and Economics, 24(2), 171-184.

Chen, X., \& Lu, W. (2017). Identifying factors influencing demolition waste generation in Hong Kong. Journal of Cleaner Production, 141, 799-811.

Chen, Y., Dib, H., \& Cox, R. F. (2014). A measurement model of Building Information Modelling maturity. Construction Innovation, 14(2), 186-209.

Cheng, J. C. P., \& Ma, L. Y. H. (2013). A BIM-based system for demolition and renovation waste estimation and planning. Waste Management, 33(6), 1539-1551.

Cheshire, D. (2016). Building Revolutions: applying the circular economy to the built environment. Newcastle upon Tyne: RIBA Publishing.

Chileshe, N., Rameezdeen, R., \& Hosseini, M. R. (2016). Drivers for adopting reverse logistics in the construction industry: a qualitative study. Engineering, Construction and Architectural Management, 23(2), 134-157.

Chileshe, N., Rameezdeen, R., Hosseini, M. R., Martek, I., Li, H. X., \& Panjehbashi-Aghdam, P. (2018). Factors driving the implementation of reverse logistics: A quantified model for the construction industry. Waste Management, 79, 48-57.

Chin, J., Dukes, R., \& Gamson, W. (2009). Assessment in simulation and gaming: A review of the last 40 Years. Simulation \& Gaming, 40(4), 553-568.

Chinda, T. (2016). Investigation of factors affecting a construction waste recycling decision. Civil Engineering and Environmental Systems, 33(3), 214-226.

Ching, F. D. (2014). Architecture: Form, space, and order. John Wiley \& Sons.

Chini, A. R. (2007). General issues of construction materials recycling in USA. Paper presented at the Sustainable construction, materials and practices: Challenges of the industry for the new millenium, Lisbon.

Chini, A. R., \& Bruening, S. F. (2003). Deconstruction and materials reuse in the United States. Retrieved from

Chini, A. R., \& Goyal, N. (2011). Country reports USA. Retrieved from Watford:

Chionna, F., Cirillo, P., Palmieri, V., \& Bellone, M. (2015). A proposed hardware-software architecture for Virtual Reality in industrial applications Augmented and Virtual Reality (pp. 287-300): Springer.

Clark, R. E. (2007). Learning from serious games? Arguments, evidence, and research suggestions. Educational Technology, 47(3), 56-59.

Coelho, A., \& De Brito, J. (2011). Economic analysis of conventional versus selective demolition-A case study. Resources, Conservation and Recycling, 55(3), 382392.

Coelho, A., \& De Brito, J. (2012). Influence of construction and demolition waste management on the environmental impact of buildings. Waste Management, 32(3), 532-541.

Coelho, A., \& De Brito, J. (2013a). Conventional demolition versus deconstruction techniques in managing construction and demolition waste (CDW) Handbook of Recycled Concrete and Demolition Waste (pp. 141-185): Woodhead Publishing. 
Coelho, A., \& De Brito, J. (2013b). Economic viability analysis of a construction and demolition waste recycling plant in Portugal - part I: location, materials, technology and economic analysis. Journal of Cleaner Production, 39, 338-352.

Computer Integrated Construction Research Program. (2010). BIM Project Execution Planning Guide - version 2.0. Retrieved from University Park, PA, USA:

Conejos, S., Langston, C., Chan, E. H. W., \& Chew, M. Y. L. (2016). Governance of heritage buildings: Australian regulatory barriers to adaptive reuse. Building Research \& Information, 44(5-6), 507-519.

Conniff, A., Craig, T., Laing, R., \& Galán-Díaz, C. (2010). A comparison of active navigation and passive observation of desktop models of future built environments. Design Studies, 31(5), 419-438.

Connolly, T. M., Boyle, E. A., MacArthur, E., Hainey, T., \& Boyle, J. M. (2012). A systematic literature review of empirical evidence on computer games and serious games. Computers \& Education, 59(2), 661-686.

Cooper, D. R., \& Gutowski, T. G. (2015). The environmental impacts of reuse: a review. Journal of Industrial Ecology.

Corsi, T. M., Boyson, S., Verbraeck, A., Van Houten, S., Han, C., \& Macdonald, J. R. (2006). The real-time global supply chain game: New educational tool for developing supply chain management professionals. Transportation Journal, 61-73.

Cox III, J. F., \& Walker, E. D. (2006). The poker chip game: A multi-product, multi-customer, multi-echelon, stochastic supply chain network useful for teaching the impacts of pull versus push inventory policies on link and chain performance. INFORMS Transactions on Education, 6(3), 3-19.

Crainer, S. (2013). Squaring the circle. Business Strategy Review, 24(4), 13-19.

Cross, N. (2008). Engineering design methods: Strategies for product design. West Sussex, England: John Wiley \& Sons.

Crowther, P. (1999). Design for Disassembly. BDP environment design guide.

Crowther, P. (2018). Re-valuing construction materials and components through design for disassembly Unmaking Waste in Production and Consumption: Towards the Circular Economy (pp. 309-321): Emerald Publishing Limited.

Cruz-Neira, C., Leigh, J., Papka, M., Barnes, C., Cohen, S. M., Das, S., . . Sandin, D. J. (1993). Scientists in wonderland: A report on visualization applications in the CAVE virtual reality environment. 59-66.

Daft, R. L., \& Lengel, R. H. (1986). Organizational information requirements, media richness and structural design. Management science, 32(5), 554-571.

Dainty, A. (2008). Methodological pluralism in construction management research. In A. Knight \& L. Ruddock (Eds.), Advanced research methods in the built environment (Vol. 1, pp. 1-13). West Sussex: Wiley-Blackwell.

Dantata, N., Touran, A., \& Wang, J. (2005). An analysis of cost and duration for deconstruction and demolition of residential buildings in Massachusetts. Resources, Conservation and Recycling, 44(1), 1-15.

Davies, R., \& Harty, C. (2013). Implementing 'Site BIM': A case study of ICT innovation on a large hospital project. Automation in Construction, 30, 15-24. 
De Almeida, P. R., Bühler, M., Gerbert, P., Castagnino, S., \& Rothballer, C. (2016). Shaping the future of construction: A breakthrough in mindset and technology. Retrieved from Cologny, Switzerland:

De Graaf, R. S., \& Dewulf, G. P. M. R. (2010). Applying the lessons of strategic urban planning learned in the developing world to the Netherlands: A case study of three industrial area development projects. Habitat International, 34(4), 471-477.

De Lieto Vollaro, R., Guattari, C., Evangelisti, L., Battista, G., Carnielo, E., \& Gori, P. (2015). Building energy performance analysis: A case study. Energy and Buildings, 87, 87-94.

Debacker, W., \& Manshoven, S. (2016). Synthesis of the state-of-the-art: Key barriers and opportunities for materials passports and reversible building design in the current system. Retrieved from https://www.bamb2020.eu/wpcontent/uploads/2016/03/D1_Synthesis-report-on-State-of-theart_20161129_FINAL.pdf

Del Río Merino, M., Izquierdo Gracia, P., \& Weis Azevedo, I. S. (2010). Sustainable construction: construction and demolition waste reconsidered. Waste Management \& Research, 28(2), 118-129.

Derry, S. J. (2007). Guidelines for video research in education. Retrieved from Chicago: http://drdc.uchicago.edu/what/video-research-guidelines.pdf

Deshpande, A. A., \& Huang, S. H. (2009). Simulation games in engineering education: A state-of-the-art review. Computer Applications in Engineering Education, 19(3), 399-410.

Diamond, J. M. (2011). How societies choose to fail or survive. London: Penguin.

Dijksma, S. A. M., \& Kamp, H. G. J. (2016). A circular economy in the Netherlands by 2050 : Government-wide programme for a circular economy. Retrieved from

Diyamandoglu, V., \& Fortuna, L. M. (2015). Deconstruction of wood-framed houses: Material recovery and environmental impact. Resources, Conservation and Recycling, 100, 21-30.

DoE. (1995). Making waste work: A strategy for sustainable waste management in England and Wales. Retrieved from London:

Dossick, C. S. (2014). Messy work in virtual worlds: exploring discovery and synthesis in virtual teams Cooperative Design, Visualization, and Engineering (pp. 134-142): Springer.

Dossick, C. S., Anderson, A., Iorio, J., Neff, G., \& Taylor, J. (2012). Messy talk and mutual discovery: exploring the necessary conditions for synthesis in virtual teams. Paper presented at the Engineering Project Organizations Conference, Rheden, the Netherlands.

Dossick, C. S., Mukherjee, A., Rojas, E. M., \& Tebo, C. (2010). Developing Construction Management Events in Situational Simulations. Computer-Aided Civil and Infrastructure Engineering, 25(3), 205-217.

Dubois, A., \& Gadde, L. E. (2000). Supply strategy and network effects - purchasing behaviour in the construction industry. European Journal of Purchasing \& Supply Management, 6(3-4), 207-215. 
Dunston, P. S., Arns, L. L., Mcglothlin, J. D., Lasker, G. C., \& Kushner, A. G. (2011). An immersive virtual reality mock-up for design review of hospital patient rooms Collaborative design in virtual environments (pp. 167-176): Springer.

Durmisevic, E. (2006). Transformable building structures: Design for disassembly as a way to introduce sustainable engineering to building design \& construction. Delft University of Technology, Delft.

Dzeng, R. J., \& Wang, P. R. (2017). C-Negotiation Game: An educational game model for construction procurement and negotiation. Automation in Construction, 75, 10 21.

Eastman, C., Teicholz, P., Sacks, R., \& Liston, K. (2011). BIM Handbook: a guide to Building Information Modeling. Hoboken: John Wiley \& Sons.

Edwards, P. K., O'Mahoney, J., \& Vincent, S. (2014). Studying organizations using critical realism: A practical guide. Oxford: Oxford University Press.

Egelhoff, W. G. (1991). Information-processing theory and the multinational enterprise. Journal of international business studies, 22(3), 341-368.

Ehn, P. (2008). Participation in Design Things. Paper presented at the Proceedings of the Tenth Anniversary Conference on Participatory Design 2008, Bloomington, Indiana.

Ehn, P., Brattgård, B., Davies, R. C., Dalholm, E., Hägerfors, A., Mitchell, B., \& Nilsson, J. (1996). The Envisioment Workshop-From Visions to Practice. Paper presented at the PDC.

Eisenhardt, K. M. (1989). Building theories from case-study research. Academy of Management Review, 14(4), 532-550.

Ellen MacArthur Foundation. (2013). Towards the circular economy: Economic and business rationale for an accelerated transition. Retrieved from https://www.ellenmacarthurfoundation.org/assets/downloads/publications/Elle n-MacArthur-Foundation-Towards-the-Circular-Economy-vol.1.pdf

Ellen MacArthur Foundation, \& Granta Design. (2015). Circularity Indicators: An approach to measuring circularity. Retrieved from https://www.ellenmacarthurfoundation.org/resources/apply/circularityindicators

Emilson, A. (2014). Designing conditions for the social. In P. Ehn, E. M. Nilsson, \& R. Topgaard (Eds.), Making futures: Marginal notes on innovation, design, and democracy (pp. 17-33). Cambridge, Massachusetts: The MIT Press.

Esposito, M., Tse, T., \& Soufani, K. (2017). Is the circular economy a new fast-expanding market? Thunderbird International Business Review, 59(1), 9-14.

Fanning, R. M., \& Gaba, D. M. (2007). The role of debriefing in simulation-based learning. Simulation in healthcare, 2(2), 115-125.

Fawcett, S. E., \& McCarter, M. W. (2008). Behavioural issues in supply chain collaboration: communicating the literature via interactive learning. International Journal of Integrated Supply Management, 4(2), 159-180.

Feger, A. L. R. (2014). Creating cross-functional strategic consensus in manufacturing facilities. International Journal of Operations and Production Management, 34(7), 941-970. 
Fisher, G., \& Aguinis, H. (2017). Using theory elaboration to make theoretical advancements. Organizational Research Methods, 20(3), 438-464.

Flyvbjerg, B. (2006). Five misunderstandings about case-study research. Qualitative Inquiry, 12(2), 219-245.

Følstad, A., Hornbæk, K., \& Ulleberg, P. (2013). Social design feedback: evaluations with users in online ad-hoc groups. Human-centric Computing and Information Sciences, 3(1), 1-27.

Froehlich, M. A., \& Azhar, S. (2016). Investigating virtual reality headset applications in construction. Paper presented at the Proceedings of the 52nd ASC International Conference, Provo, UT.

Frosch, R. A., \& Gallopoulos, N. E. (1989). Strategies for manufacturing. Scientific American, 261(3), 144-153.

Galbraith, J. R. (1973). Designing Complex Organizations. Addison-Wesley Longman Publishing.

Galbraith, J. R. (1974). Organization design: An information processing view. Interfaces, $4(3), 28-36$.

Galbraith, J. R. (1977). Organization design. Addison Wesley Publishing Company.

Gálvez-Martos, J. L., Styles, D., Schoenberger, H., \& Zeschmar-Lahl, B. (2018). Construction and demolition waste best management practice in Europe. Resources, Conservation and Recycling, 136, 166-178.

Garcia, A. C. B., Kunz, J., \& Fischer, M. (2005). Voting on the agenda: the key to social efficient meetings. International Journal of Project Management, 23(1), 17-24.

Ge, X. J., Livesey, P., Wang, J., Huang, S. H., He, X., \& Zhang, C. (2017). Deconstruction waste management through $3 \mathrm{~d}$ reconstruction and bim: a case study. Visualization in Engineering, 5(1), 13.

Germani, M., Mengoni, M., \& Peruzzini, M. (2012). An approach to assessing virtual environments for synchronous and remote collaborative design. Advanced Engineering Informatics, 26(4), 793-813.

Ghisellini, P., Cialani, C., \& Ulgiati, S. (2016). A review on circular economy: the expected transition to a balanced interplay of environmental and economic systems. Journal of Cleaner Production, 114, 11-32.

Gordon, R. B., Bertram, M., \& Graedel, T. E. (2006). Metal stocks and sustainability. Proceedings of the National Academy of Sciences, 103(5), 1209-1214.

Gorgolewski, M. (2008). Designing with reused building components: some challenges. Building Research \& Information, 36(2), 175-188.

Gort, R. (2015). Lean vertaald naar projecten: samen leren bouwen aan innovatievermogen. Amsterdam: Pumbo.nl.

Graedel, T. E., \& Allenby, B. R. (2010). Industrial ecology and sustainable engineering. Upper Saddle River, NJ: Prentice Hall.

Gray, D. E. (2013). Doing research in the real world. Los Angeles: Sage.

Grosse, H. (2018). An insider's point of view: autoethnography in the construction industry. Construction Management and Economics, 1-18.

$\mathrm{Gu}$, N., \& London, K. (2010). Understanding and facilitating BIM adoption in the AEC industry. Automation in Construction, 19(8), 988-999. 
Gül, L. F. (2009). Evaluating design behaviour when using emerging collaboration technologies. Architectural Engineering and Design Management, 5(3), 107-123.

Guy, B., Shell, S., \& Esherick, H. (2006). Design for deconstruction and materials reuse. Paper presented at the CIB Task Group.

Haas, W., Krausmann, F., Wiedenhofer, D., \& Heinz, M. (2015). How circular is the global economy?: An assessment of material flows, waste production, and recycling in the European Union and the world in 2005. Journal of Industrial Ecology, 19(5), 765-777.

Harteveld, C. (2011). Triadic game design: Balancing Reality, Meaning and Play. Heidelberg: Springer.

Hartmann, T., \& Fischer, M. (2007). Supporting the constructability review with 3D/4D models. Building Research \& Information, 35(1), 70-80.

Hartmann, T., Fischer, M., \& Haymaker, J. (2009). Implementing information systems with project teams using ethnographic-action research. Advanced Engineering Informatics, 23(1), 57-67.

Hartmann, T., Gao, J., \& Fischer, M. (2008). Areas of application for 3D and 4D models on construction projects. Journal of Construction Engineering and Management, 134(10), 776-785.

Hartmann, T., Van Meerveld, H., Vossebeld, N., \& Adriaanse, A. (2012). Aligning Building Information Model tools and construction management methods. Automation in Construction, 22, 605-613.

Hegazy, T., Abdel-Monem, M., Saad, D. A., \& Rashedi, R. (2013). Hands-On Exercise for Enhancing Students' Construction Management Skills. Journal of Construction Engineering and Management, 139(9), 1135-1143.

Henckens, M. L. C. M., Van Ierland, E. C., Driessen, P. P. J., \& Worrell, E. (2016). Mineral resources: Geological scarcity, market price trends, and future generations. Resources Policy, 49, 102-111.

Holweg, M., \& Bicheno, J. (2002). Supply chain simulation - a tool for education, enhancement and endeavour. International Journal of Production Economics, 78(2), 163-175.

Hong, J., Shen, G. Q., Guo, S., Xue, F., \& Zheng, W. (2016). Energy use embodied in China' $\mathrm{s}$ construction industry: A multi-regional input-output analysis. Renewable and sustainable energy reviews, 53, 1303-1312.

Hossain, M. U., \& Ng, S. T. (2018). Critical consideration of buildings' environmental impact assessment towards adoption of circular economy: An analytical review. Journal of Cleaner Production, 205, 763-780.

Hosseini, M. R., Chileshe, N., Rameezdeen, R., \& Lehmann, S. (2014). Reverse logistics for the construction industry: Lessons from the manufacturing context. International Journal of Construction Engineering and Management, 3(3), 75-90.

Hosseini, M. R., Rameezdeen, R., Chileshe, N., \& Lehmann, S. (2015). Reverse logistics in the construction industry. Waste Management \& Research, 33(6), 499-514.

Hussein, B. (2015). A blended learning approach to teaching project management: a model for active participation and involvement: insights from Norway. Education Sciences, 5(2), 104-125. 
Huuhka, S., \& Lahdensivu, J. (2016). Statistical and geographical study on demolished buildings. Building Research \& Information, 44(1), 73-96.

Iacovidou, E., \& Purnell, P. (2016). Mining the physical infrastructure: Opportunities, barriers and interventions in promoting structural components reuse. Science of the Total Environment, 557, 791-807.

Iorio, J., \& Taylor, J. E. (2014). Boundary object efficacy: the mediating role of boundary objects on task conflict in global virtual project networks. International Journal of Project Management, 32(1), 7-17.

Iorio, J., Taylor, J. E., \& Dossick, C. S. (2011). A bridge too far: examining the impact of facilitators on information transfer in global project networks. Proceedings Editor.

Jalaei, F., \& Jrade, A. (2014). An automated BIM model to conceptually design, analyze, simulate, and assess sustainable building projects. Journal of Construction Engineering, 2014.

Jensen, P. A. (2011). Inclusive briefing and user involvement: Case study of a media centre in Denmark. Architectural Engineering and Design Management, 7(1), 38-49.

Jin, R., Li, B., Zhou, T., Wanatowski, D., \& Piroozfar, P. (2017). An empirical study of perceptions towards construction and demolition waste recycling and reuse in China. Resources, Conservation and Recycling, 126, 86-98.

Jordan, B., \& Henderson, A. (1995). Interaction analysis: Foundations and practice. The journal of the learning sciences, 4(1), 39-103.

Kalmykova, Y., Sadagopan, M., \& Rosado, L. (2018). Circular economy-From review of theories and practices to development of implementation tools. Resources, Conservation and Recycling, 135, 190-201.

Kibert, C. J. (2016). Sustainable construction: green building design and delivery. John Wiley \& Sons.

Kibert, C. J., Chini, A. R., \& Languell, J. (2001). Deconstruction as an essential component of sustainable construction. Paper presented at the CIB World Building Congress, Wellington, New Zealand

Kim, M. J., Wang, X., Love, P., Li, H., \& Kang, S. C. (2013). Virtual reality for the built environment: a critical review of recent advances. Journal of Information Technology in Construction, 18, 279-305.

Kirchherr, J., Reike, D., \& Hekkert, M. (2017). Conceptualizing the circular economy: An analysis of 114 definitions. Resources, Conservation and Recycling, 127, 221-232.

Kleemann, F., Lederer, J., Aschenbrenner, P., Rechberger, H., \& Fellner, J. (2016). A method for determining buildings' material composition prior to demolition. Building Research \& Information, 44(1), 51-62.

Koenen, S., \& Kuipers, A. (2012). Droomvlucht. Amsterdam: Dutch Media Uitgevers.

Kolb, D. A. (1984). Experiential learning: Experience as the source of learning and development. Upper Saddle River: Prentice Hall.

Kolb, D. A., Boyatzis, R. E., \& Mainemelis, C. (2001). Experiential learning theory: Previous research and new directions. In R. J. Sternberg \& L. F. Zhang (Eds.), Perspectives on thinking, learning, and cognitive styles (Vol. 1, pp. 227-247): Routledge.

Korhonen, J., Honkasalo, A., \& Seppälä, J. (2018). Circular Economy: The Concept and its Limitations. Ecological Economics, 143(Supplement C), 37-46. 
Koskela, L. (1992). Application of the new production philosophy to construction: Stanford University Stanford, CA.

Koskela, L., \& Ballard, G. (2006). Should project management be based on theories of economics or production? Building Research \& Information, 34(2), 154-163.

Koskela, L., Howell, G., Ballard, G., \& Tommelein, I. (2002). The foundations of lean construction Design and Construction: Building in Value. Oxford, UK: Butterworth-Heinemann.

Kourmpanis, B., Papadopoulos, A., Moustakas, K., Stylianou, M., Haralambous, K. J., \& Loizidou, M. (2008). Preliminary study for the management of construction and demolition waste. Waste Management \& Research, 26(3), 267-275.

Koutamanis, A., Van Reijn, B., \& Van Bueren, E. (2018). Urban mining and buildings: A review of possibilities and limitations. Resources, Conservation and Recycling, 138, 32-39.

Koutsabasis, P., Vosinakis, S., Malisova, K., \& Paparounas, N. (2012). On the value of Virtual Worlds for collaborative design. Design Studies, 33(4), 357-390.

Kreider, R. G., \& Messner, J. I. (2013). The Uses of BIM: Classifying and selecting BIM Uses. Retrieved from University Park, PA, USA: http://bim.psu.edu

Kreye, M. E. (2017). Relational uncertainty in service dyads. International Journal of Operations and Production Management, 37(3), 363-381.

Kristiansen, P., \& Rasmussen, R. (2014). Building a better business using the LEGO SERIOUS PLAY method: John Wiley \& Sons.

Kumar, S., Hedrick, M., Wiacek, C., \& Messner, J. I. (2011). Developing an experiencedbased design review application for healthcare facilities using a 3D game engine. Journal of Information Technology in Construction, 16, 84-103.

Laefer, D. F., \& Manke, J. P. (2008). Building reuse assessment for sustainable urban reconstruction. Journal of Construction Engineering and Management, 134(3), 217-227.

Lansink, A. (2017). Challenging changes: Connecting waste hierarchy and circular economy. Nijmegen: DPN Rikken.

Latour, B. (2005a). From Realpolitik to Dingpolitik. In B. Latour \& P. Weibel (Eds.), Making things public: Atmospheres of democracy (pp. 14-44). London: The MIT Press.

Latour, B. (2005b). Reassembling the social: An introduction to Actor-Network-Theory. Oxford: Oxford University Press.

Latour, B. (2008). A cautious Prometheus? A few steps toward a philosophy of design (with special attention to Peter Sloterdijk). Paper presented at the Proceedings of the 2008 annual international conference of the design history society.

Latour, B., \& Yaneva, A. (2008). Give me a gun and I will make all buildings move: An ANT's view of architecture. Basel: Birkhäuser.

Le Dantec, C. A., \& Do, E. Y. L. (2009). The mechanisms of value transfer in design meetings. Design Studies, 30(2), 119-137.

Leedy, P. D., \& Ormrod, J. E. (2010). Practical research: planning and design. New Jersey: Pearson Education.

Leising, E., Quist, J., \& Bocken, N. (2018). Circular Economy in the building sector: Three cases and a collaboration tool. Journal of Cleaner Production, 176, 976-989. 
Levander, E., Engström, S., Sardén, Y., \& Stehn, L. (2011). Construction clients' ability to manage uncertainty and equivocality. Construction Management and Economics, 29(7), 753-764.

Levitt, R. E., Thomsen, J., Christiansen, T. R., Kunz, J. C., Jin, Y., \& Nass, C. (1999). Simulating project work processes and organizations: Toward a micro-contingency theory of organizational design. Management science, 45(11), 1479-1495.

Li, H., Huang, T., Kong, C. W., Guo, H. L., Baldwin, A., Chan, N., \& Wong, J. (2008). Integrating design and construction through virtual prototyping. Automation in Construction, 17(8), 915-922.

Lieder, M., \& Rashid, A. (2016). Towards circular economy implementation: a comprehensive review in context of manufacturing industry. Journal of Cleaner Production, 115, 36-51.

Lindhard, S. (2014). Understanding the Effect of Variation in a Production System. Journal of Construction Engineering and Management, 140(11), 04014051.

Llatas, C. (2011). A model for quantifying construction waste in projects according to the European waste list. Waste Management, 31(6), 1261-1276.

Long, Q., \& Zhang, W. (2014). An integrated framework for agent based inventoryproduction-transportation modeling and distributed simulation of supply chains. Information Sciences, 277, 567-581.

Love, P. E. D., Irani, Z., \& Edwards, D. J. (2004). A seamless supply chain management model for construction. Supply Chain Management: An International Journal, 9(1), 4356.

Löwstedt, M. (2015). 'Taking off my glasses in order to see': exploring practice on a building site using self-reflexive ethnography. Construction Management and Economics, 33(5-6), 404-414.

Luscuere, L. M. (2017). Materials Passports: Optimising value recovery from materials. Proceedings of the Institution of Civil Engineers - Waste and Resource Management, 170(1), 25-28.

Mahpour, A. (2018). Prioritizing barriers to adopt circular economy in construction and demolition waste management. Resources, Conservation and Recycling, 134, 216-227.

Majumdar, T., Fischer, M. A., \& Schwegler, B. (2006). Conceptual design review with a virtual reality mock-up model. Paper presented at the Building on IT: joint international conference on computing and decision making in civil and building engineering. Montreal, Canada: American Society of Civil Engineers.

Malone, T. W., \& Crowston, K. (1994). The interdisciplinary study of coordination. ACM Computing Surveys (CSUR), 26(1), 87-119.

Mawdesley, M., Long, G., Al-jibouri, S., \& Scott, D. (2011). The enhancement of simulation based learning exercises through formalised reflection, focus groups and group presentation. Computers \& Education, 56(1), 44-52.

McDonough, W., \& Braungart, M. (1998). The next industrial revolution. The atlantic monthly, 282(4).

McDonough, W., \& Braungart, M. (2002). Cradle to cradle: Remaking the way we make things. The North Point Press. 
McDonough, W., \& Braungart, M. (2010). Cradle to cradle: Remaking the way we make things. The North Point Press.

McDonough, W., Braungart, M., Anastas, P. T., \& Zimmerman, J. B. (2003). Peer reviewed: Applying the principles of green engineering to cradle-to-cradle design: ACS Publications.

McDowall, W., Geng, Y., Huang, B., Barteková, E., Bleischwitz, R., Türkeli, S., . . Doménech, T. (2017). Circular economy policies in China and Europe. Journal of Industrial Ecology, 21(3), 651-661.

Meadows, D. H., Meadows, D. L., Randers, J., \& Behrens, W. W. (1972). The Limits to Growth: A report for the Club of Rome's project on the predicament of mankind. New York: Universe Books.

Meijboom, B., Voordijk, H., \& Akkermans, H. (2007). The effect of industry clockspeed on supply chain co-ordination: Classical theory to sharpen an emerging concept. Business Process Management Journal, 13(4), 553-571.

Merli, R., Preziosi, M., \& Acampora, A. (2018). How do scholars approach the circular economy? A systematic literature review. Journal of Cleaner Production, 178, 703-722.

Merrick, K. E., Gu, N., \& Wang, X. (2011). Case studies using multiuser virtual worlds as an innovative platform for collaborative design: ITcon.

Mikropoulos, T. A., \& Natsis, A. (2011). Educational virtual environments: A ten-year review of empirical research (1999-2009). Computers \& Education, 56(3), 769-780.

Miles, M. B., \& Huberman, A. M. (1994). Qualitative data analysis: An expanded sourcebook. Thoasand Oaks, CA: Sage.

Min, J. U., \& Bjornsson, H. C. (2008). Agent-based construction supply chain simulator (CS2) for measuring the value of real-time information sharing in construction. Journal of Management in Engineering, 24(4), 245-254.

Mobach, M. P. (2008). Do virtual worlds create better real worlds? Virtual Reality, 12(3), 163-179.

Moum, A. (2010). Design team stories: exploring interdisciplinary use of 3D object models in practice. Automation in Construction, 19(5), 554-569.

Muis, R. (2016, September 28). Modulair gebouwd, toch gesloopt. Architectenweb. Retrieved from https://architectenweb.nl/nieuws/artikel.aspx?ID=39654

Murray, R., Caulier-Grice, J., \& Mulgan, G. (2010). The open book of social innovation: National endowment for science, technology and the art.

Musante, K., \& DeWalt, B. R. (2010). Participant observation: A guide for fieldworkers. Rowman Altamira.

Namian, M., Albert, A., Zuluaga, C. M., \& Behm, M. (2016). Role of safety training: Impact on hazard recognition and safety risk perception. Journal of Construction Engineering and Management, 142(12), 04016073.

Nassar, K. (2003). Construction contracts in a competitive market: C3M, a simulation game. Engineering, Construction and Architectural Management, 10(3), 172-178.

Ness, D., Swift, J., Ranasinghe, D. C., Xing, K., \& Soebarto, V. (2015). Smart steel: new paradigms for the reuse of steel enabled by digital tracking and modelling. Journal of Cleaner Production, 98, 292-303. 
Nguyen, H., Stuchtey, M., \& Zils, M. (2014). Remaking the industrial economy. McKinsey Quarterly, 1, 46-63.

Oak, A. (2011). What can talk tell us about design?: Analyzing conversation to understand practice. Design Studies, 32(3), 211-234.

Olde Scholtenhuis, L. L., Hartmann, T., \& Dorée, A. G. (2016). Testing the value of 4D visualizations for enhancing mindfulness in utility reconstruction works. Journal of Construction Engineering and Management, 142(7), 04016015.

Parto, S., Loorbach, D., Lansink, A., \& Kemp, R. (2007). Transitions and Institutional Change: The case of the Dutch waste subsystem. In S. Parto \& B. Herbert-Copley (Eds.), Industrial innovation and environmental regulation. Tokyo: United Nations University Press.

Paton, B., \& Dorst, K. (2011). Briefing and reframing: A situated practice. Design Studies, 32(6), 573-587.

Peterson, F., Hartmann, T., Fruchter, R., \& Fischer, M. (2011). Teaching construction project management with BIM support: Experience and lessons learned. Automation in Construction, 20(2), 115-125.

Phelps, A. F., \& Horman, M. J. (2009). Ethnographic theory-building research in construction. Journal of Construction Engineering and Management, 136(1), 5865 .

Pink, S., Tutt, D., Dainty, A., \& Gibb, A. (2010). Ethnographic methodologies for construction research: knowing, practice and interventions. Building Research \& Information, 38(6), 647-659.

Pomponi, F., \& Moncaster, A. (2016). Embodied carbon mitigation and reduction in the built environment - What does the evidence say? Journal of Environmental Management, 181, 687-700.

Pomponi, F., \& Moncaster, A. (2017). Circular economy for the built environment: A research framework. Journal of Cleaner Production, 143, 710-718.

Poon, C. S., Yu, A. T. W., See, S. C., \& Cheung, E. (2004). Minimizing demolition wastes in Hong Kong public housing projects. Construction Management and Economics, 22(8), 799-805.

Premkumar, G., Ramamurthy, K., \& Saunders, C. S. (2005). Information processing view of organizations: An exploratory examination of fit in the context of interorganizational relationships. Journal of Management Information Systems, 22(1), 257-294.

Pun, S. K., Liu, C., \& Langston, C. (2006). Case study of demolition costs of residential buildings. Construction Management and Economics, 24(9), 967-976.

Rau, T., \& Oberhuber, S. (2016). Material matters: Hoe wij onze relatie met de aarde kunnen veranderen. Vlaardingen: Bertram + de Leeuw Uitgevers BV.

Remøy, H., \& van der Voordt, T. (2014). Adaptive reuse of office buildings into housing: opportunities and risks. Building Research \& Information, 42(3), 381-390.

Rogers, D. S., \& Tibben-Lembke, R. S. (1999). Going backwards: reverse logistics trends and practices (Vol. 2): Reverse Logistics Executive Council Pittsburgh, PA.

Rojas, E. M., \& Mukherjee, A. (2005). General-purpose situational simulation environment for construction education. Journal of Construction Engineering and Management, 131(3), 319-329. 
Rosenman, M. A., Smith, G., Maher, M. L., Ding, L., \& Marchant, D. (2007). Multidisciplinary collaborative design in virtual environments. Automation in Construction, 16(1), 37-44.

Roussos, M., Johnson, A., Moher, T., Leigh, J., Vasilakis, C., \& Barnes, C. (1999). Learning and building together in an immersive virtual world. Presence: Teleoperators and Virtual Environments, 8(3), 247-263.

Rüppel, U., \& Schatz, K. (2011). Designing a BIM-based serious game for fire safety evacuation simulations. Advanced Engineering Informatics, 25(4), 600-611.

Rwamamara, R., Norberg, H., Olofsson, T., \& Lagerqvist, O. (2010). Using visualization technologies for design and planning of a healthy construction workplace. Construction Innovation, 10(3), 248-266.

Sacks, R., Esquenazi, A., \& Goldin, M. (2007). LEAPCON: Simulation of lean construction of high-rise apartment buildings. Journal of Construction Engineering and Management, 133(7), 529-539.

Sacks, R., \& Goldin, M. (2007). Lean Management Model for Construction of High-Rise Apartment Buildings. Journal of Construction Engineering and Management, 133(5), 374-384.

Sacks, R., Koskela, L., Dave, B. A., \& Owen, R. (2010). Interaction of Lean and Building Information Modeling in Construction. Journal of Construction Engineering and Management, 136(9), 968-980.

Sacks, R., Perlman, A., \& Barak, R. (2013). Construction safety training using immersive virtual reality. Construction Management and Economics, 31(9), 1005-1017.

Sacks, R., Radosavljevic, M., \& Barak, R. (2010). Requirements for building information modeling based lean production management systems for construction. Automation in Construction, 19(5), 641-655.

Salter, A., \& Torbett, R. (2003). Innovation and performance in engineering design. Construction Management and Economics, 21(6), 573-580.

Sampaio, A. Z., \& Martins, O. P. (2014). The application of virtual reality technology in the construction of bridge: The cantilever and incremental launching methods. Automation in Construction, 37, 58-67.

Sauvé, S., Bernard, S., \& Sloan, P. (2016). Environmental sciences, sustainable development and circular economy: Alternative concepts for trans-disciplinary research. Environmental Development, 17, 48-56.

Schell, J. (2008). The Art of Game Design: A book of lenses. CRC Press.

Schoffelen, J., Claes, S., Huybrechts, L., Martens, S., Chua, A., \& Moere, A. V. (2015). Visualising things. Perspectives on how to make things public through visualisation. CoDesign, 11(3-4), 179-192.

Schultmann, F., \& Sunke, N. (2007). Energy-oriented deconstruction and recovery planning. Building Research \& Information, 35(6), 602-615.

Sebastian, R., \& Van Berlo, L. (2010). Tool for benchmarking BIM performance of design, engineering and construction firms in the Netherlands. Architectural Engineering and Design Management, 6(4), 254-263.

Segerstedt, A., \& Olofsson, T. (2010). Supply chains in the construction industry. Supply Chain Management: An International Journal, 15(5), 347-353. 
Shen, W., Shen, Q., \& Sun, Q. (2012). Building Information Modeling-based user activity simulation and evaluation method for improving designer-user communications. Automation in Construction, 21(0), 148-160.

Shen, W., Zhang, X., Shen, G. Q., \& Fernando, T. (2013). The user pre-occupancy evaluation method in designer-client communication in early design stage: A case study. Automation in Construction, 32, 112-124.

Shiratuddin, M. F., \& Thabet, W. (2007). Information rich Virtual Environment (VE) design review. Paper presented at the 24th W78 Conference \& 5th ITCEDU Workshop \& 14ht EG-ICE Workshop, Maribor, Slovenia.

Shiratuddin, M. F., \& Thabet, W. (2011). Utilizing a 3D game engine to develop a virtual design review system. Journal of Information Technology in Construction, 16, 3968.

Siebelink, S., Voordijk, J. T., \& Adriaanse, A. (2018). Developing and testing a tool to evaluate BIM maturity: Sectoral analysis in the Dutch construction industry. Journal of Construction Engineering and Management, 144(8), 05018007.

Silva, R. V., De Brito, J., \& Dhir, R. K. (2017). Availability and processing of recycled aggregates within the construction and demolition supply chain: A review. Journal of Cleaner Production, 143, 598-614.

Smyth, H. J., \& Morris, P. W. G. (2007). An epistemological evaluation of research into projects and their management: Methodological issues. International Journal of Project Management, 25(4), 423-436.

Son, J., \& Rojas, E. M. (2011). Evolution of collaboration in temporary project teams: An agent-based modeling and simulation approach. Journal of Construction Engineering and Management, 137(8), 619-628.

Spradley, J. P. (1979). The ethnographic interview. New York: Holt, Rinehart and Winston.

Spradley, J. P. (1980). Participant observation. New York: Holt, Rinehart and Wineston.

Sterman, J. D. (1989). Modeling managerial behavior: Misperceptions of feedback in a dynamic decision making experiment. Management science, 35(3), 321-339.

Storni, C., Binder, T., Linde, P., \& Stuedahl, D. (2015). Designing things together: intersections of co-design and actor-network theory. CoDesign, 11(3-4), 149-

Succar, B. (2009). Building information modelling framework: A research and delivery foundation for industry stakeholders. Automation in Construction, 18(3), 357375.

Succar, B., Sher, W., \& Williams, A. (2012). Measuring BIM performance: Five metrics. Architectural Engineering and Design Management, 8(2), 120-142.

Susi, T., Johannesson, M., \& Backlund, P. (2007). Serious games: An overview. IKI Technical Reports.

Tam, V. W. Y., \& Tam, C. M. (2006). A review on the viable technology for construction waste recycling. Resources, Conservation and Recycling, 47(3), 209-221.

Thackara, J. (2015). How to thrive in the next economy: Designing tomorrow's world today. London: Thames \& Hudson.

Thelen, D., Van Acoleyen, M., Huurman, W., Thomaes, T., Van Brunschot, C., Brendan, E., \& Kubbinga, B. (2018). Scaling the circular built environment: Pathways for business and government. Retrieved from 
https://docs.wbcsd.org/2018/12/Scaling_the_Circular_Built_Environmentpathways_for_business_and_government.pdf

Thomas, J. B., \& Trevino, L. K. (1993). Information processing in strategic alliance building: A multiple-case approach. Journal of Management Studies, 30(5), 779-814.

Thomsen, A., Schultmann, F., \& Kohler, N. (2011). Deconstruction, demolition and destruction. Building Research \& Information, 39(4), 327-332.

Thomsen, A., \& Van der Flier, K. (2009). Replacement or renovation of dwellings: the relevance of a more sustainable approach. Building Research \& Information, 37(5-6), 649-659.

Thomsen, A., \& Van der Flier, K. (2011). Understanding obsolescence: a conceptual model for buildings. Building Research \& Information, 39(4), 352-362.

Thyssen, M. H., Emmitt, S., Bonke, S., \& Kirk-Christoffersen, A. (2010). Facilitating client value creation in the conceptual design phase of construction projects: A workshop approach. Architectural Engineering and Design Management, 6(1), 18-30.

Tommelein, I. D., Ballard, G., \& Kaminsky, P. (2008). Supply chain management for lean project delivery Handbook of Construction Supply Chain Management. Boca Ranton, FL: CRC Press.

Tommelein, I. D., Riley, D. R., \& Howell, G. A. (1999). Parade game: Impact of work flow variability on trade performance. Journal of Construction Engineering and Management, 125(5), 304-310.

Trebbe, M., Hartmann, T., \& Dorée, A. G. (2015). 4D CAD models to support the coordination of construction activities between contractors. Automation in Construction, 49, 83-91.

Trochim, W. M. K. (1989). Outcome pattern matching and program theory. Evaluation and program planning, 12(4), 355-366.

Tsai, J. S., \& Chi, C. S. F. (2015). Learning for win-win collaboration. Journal of Construction Engineering and Management, 141(7).

Turk, Ž. (2016). Ten questions concerning Building Information Modelling. Building and Environment, 107, 274-284.

Tushman, M. L., \& Nadler, D. A. (1978). Information Processing as an Integrating Concept in Organizational Design. Academy of Management Review, 3(3), 613-624.

Udawatta, N., Zuo, J., Chiveralls, K., \& Zillante, G. (2015). Improving waste management in construction projects: An Australian study. Resources, Conservation and Recycling, 101, 73-83.

Unsal, H. I., \& Taylor, J. E. (2011). An empirical investigation of opportunistic behaviour in project networks and its impact on market efficiency. The Engineering Project Organization Journal, 1(2), 95-106.

Van Amstel, F. M. C., Zerjav, V., Hartmann, T., Dewulf, G. P. M. R., \& Van der Voort, M. C. (2016). Expensive or expansive? Learning the value of boundary crossing in design projects. Engineering Project Organization Journal, 1-15.

Van den Berg, M., Hartmann, T., \& De Graaf, R. (2017). Supporting design reviews with pre-meeting virtual reality environments. Journal of Information Technology in Construction, 22(16), 305-321. 
Van den Berg, M., Voordijk, H., \& Adriaanse, A. (2017). Coordinating reverse logistics in construction: mechanisms to manage uncertainties for various disposition scenarios. Paper presented at the IPSERA 2017 Conference, BudapestBalatonfüred.

Van den Berg, M., Voordijk, H., Adriaanse, A., \& Hartmann, T. (2017). Experiencing supply chain optimizations: A serious gaming approach. Journal of Construction Engineering and Management, 143(11), 1-14.

Van Tongerloo, R. (2018, March 27). Waarom astronauten vaak klimaatactivisten worden. Retrieved from https://brandpuntplus.kro-ncrv.nl/brandpuntplus/klimaatkuipers/

Venturini, T. (2010). Diving in magma: How to explore controversies with actor-network theory. Public understanding of science, 19(3), 258-273.

Venturini, T., Ricci, D., Mauri, M., Kimbell, L., \& Meunier, A. (2015). Designing controversies and their publics. Design Issues, 31(3), 74-87.

Volk, R., Stengel, J., \& Schultmann, F. (2014). Building Information Modeling (BIM) for existing buildings - Literature review and future needs. Automation in Construction, 38, 109-127.

Voordijk, H. (2009). Construction management and economics: the epistemology of a multidisciplinary design science. Construction Management and Economics, 27(8), 713-720.

Vrijhoef, R., \& Koskela, L. (2000). The four roles of supply chain management in construction. European Journal of Purchasing \& Supply Management, 6(3-4), 169-178.

Wang, J., Wang, X., Shou, W., \& Xu, B. (2014). Integrating BIM and augmented reality for interactive architectural visualisation. Construction Innovation, 14(4), 453-476.

Wang, T., Wang, J., Wu, P., Wang, J., He, Q., \& Wang, X. (2018). Estimating the environmental costs and benefits of demolition waste using life cycle assessment and willingness-to-pay: A case study in Shenzhen. Journal of Cleaner Production, $172,14-26$.

Wassenberg, F. (2011). Demolition in the Bijlmermeer: lessons from transforming a large housing estate. Building Research \& Information, 39(4), 363-379.

Watkins, M., Mukherjee, A., Onder, N., \& Mattila, K. (2009). Using agent-based modeling to study construction labor productivity as an emergent property of individual and crew interactions. Journal of Construction Engineering and Management, 135(7), 657-667.

Weick, K. E. (1979). The social psychology of organizing. Reading, MA: Addison-Wesley. White, F. (1998). The overview effect: Space exploration and human evolution: AIAA.

Whyte, J. (2002). Virtual Reality and the built environment. Oxford: Elsevier Science.

Wiengarten, F., Ahmed, M. U., Longoni, A., Pagell, M., \& Fynes, B. (2017). Complexity and the triple bottom line: an information-processing perspective. International Journal of Operations and Production Management, 37(9), 1142-1163.

Winch, G. M. (2010). Managing construction projects. Chisester: Blackwell Publishing Ltd. Winch, G. M. (2015). Project organizing as a problem in information. Construction Management and Economics, 33(2), 106-116. 
Woksepp, S., \& Olofsson, T. (2006). Using virtual reality in a large-scale industry project. Journal of Information Technology in Construction, 11(43), 627-640.

Woksepp, S., \& Olofsson, T. (2008). Credibility and applicability of virtual reality models in design and construction. Advanced Engineering Informatics, 22(4), 520-528.

Won, J., \& Cheng, J. C. P. (2017). Identifying potential opportunities of Building Information Modeling for construction and demolition waste management and minimization. Automation in Construction, 79, 3-18.

Wong, J. K. W., \& Zhou, J. (2015). Enhancing environmental sustainability over building life cycles through green BIM: A review. Automation in Construction, 57, 156-165.

Wu, Z., Yu, A. T. W., Shen, L., \& Liu, G. (2014). Quantifying construction and demolition waste: an analytical review. Waste Management, 34(9), 1683-1692.

Xue, X., Li, X., Shen, Q., \& Wang, Y. (2005). An agent-based framework for supply chain coordination in construction. Automation in Construction, 14(3), 413-430.

Yan, W., Culp, C., \& Graf, R. (2011). Integrating BIM and gaming for real-time interactive architectural visualization. Automation in Construction, 20(4), 446-458.

Yin, R. K. (2009). Case Study Research: Design and Methods (4 ed.). Thousand Oaks: Sage.

Yin, R. K. (2013). Validity and generalization in future case study evaluations. Evaluation, 19(3), 321-332. 
Supplements 


\section{Appendix I: Publication record}

This appendix provides an overview of papers produced during the PhD research trajectory.

\section{Journal papers (peer reviewed)}

Van den Berg, M., Voordijk, H., \& Adriaanse, A. (under review). Recovering building objects for reuse (or not).

Van den Berg, M., Voordijk, H., \& Adriaanse, A. (under review). Information processing for end-of-life coordination: A multiple-case study.

Van den Berg, M., Voordijk, H. \& Adriaanse, A. (under review). BIM uses for deconstruction practices: Three ethnographic-action insights.

Van den Berg, M., Hartmann, T., \& De Graaf, R. (2017). Supporting design reviews with pre-meeting virtual reality environments. Journal of Information Technology in Construction, 22(16), 305-321.

Van den Berg, M., Voordijk, H., Adriaanse, A., \& Hartmann, T. (2017). Experiencing supply chain optimizations: A serious gaming approach. Journal of Construction Engineering and Management, 143(11), 1-14.

\section{Scientific conference papers (peer reviewed)}

Van den Berg, M., Voordijk, H., \& Adriaanse, A. (2018). Supporting deconstruction practices with information systems using ethnographic-action research. Paper presented at the $34^{\text {th }}$ ARCOM Conference, Belfast, UK.

Van den Berg, M., Vasenev, A., Voordijk, H., \& Adriaanse, A. (2018). Low-tech or high-tech? Relative learning benefits of serious games for construction supply chain management. Paper presented at the $28^{\text {th }}$ IPSERA Conference, Athens.

Van den Berg, M., \& Durmisevic, E. (2017). BIM uses for reversible building design: Identification, elaboration \& classification. Paper presented at the $3^{\text {rd }}$ Green Design Conference, Mostar, Bosnia-Herzegovina.

Van den Berg, M., Voordijk, H., \& Adriaanse, A. (2017). Coordinating reverse logistics in construction: mechanisms to manage uncertainties for various disposition scenarios. Paper presented at the $27^{\text {th }}$ IPSERA Conference, Budapest-Balatonfüred. 


\section{Appendix II: Complementary research work}

With this thesis, I set out on a journey to enable a circular built environment. I also made several trips to adjacent fields that did not contribute to this thesis' overall goal directly. This appendix discusses those trips. The complementary research works include: (I) a longitudinal study on circularity challenges and solutions in a design project, (II) an exploratory experiment to assess relative learning benefits of low-tech and high-tech serious games, (III) a multiple-case study on designing Things to explore controversies and (IV) BIM solutions for integrated project management of reversible buildings.

\section{I: Circularity challenges and solutions in a design project (ongoing)}

This (ongoing) longitudinal study reflects on the challenges that a design team faces in applying circularity thinking in a renovation project. Research activities include observations of design meetings, the development of a Circular Project Model centered around material flows and an interactive workshop with architects/designers.

As part of an emergent transition towards a circular economy, design professionals need to fundamentally rethink their design practices. The construction industry is recognized as one of the most resource intensive and polluting industries. One of the root causes of the significant amounts of construction and demolition waste associated with the industry is the designers' traditional view of their creations being permanent (Durmisevic, 2006). As a result, most buildings can poorly adapt to changing user needs. New usages do happen though and they "persistently retire or reshape buildings" (Brand, 1994). The designs then typically leave conventional demolition, in which a building is converted into mixed waste, as the only viable end-of-life option. To allow building transformations and recovery practices, researchers have proposed a "circular" model of production that is restorative or regenerative by intention (Ellen MacArthur Foundation, 2013; Pomponi \& Moncaster, 2017). Designers and architects, however, lack systematic methodologies to help them move forward and documented examples of real-world circular design practices are scarce.

This action research study aims to explore how circularity challenges can be better understood while attempting to solve them in an actual design project. Action research consists of five interrelated steps that researchers perform in collaboration with practitioners (Azhar et al., 2009): I - Diagnosing (identifying research problems); II - Action planning (developing an intervention); III - Action taking (implementing the intervention); IV - Evaluating (assessing the outcomes); and $V$ - Specifying learning (abstracting different types of knowledge). The action 
research approach was adopted within the context of an architectural and engineering design project. The project concerns the renovation of a primary school building (which houses two schools) located in the eastern part of the Netherlands. In line with the tenets of action research, data was collected during all five research steps. The first mentioned researcher observed 17 design meetings over a six-month period and received minutes of these and 6 other design meetings. He also visited the school building twice and collected relevant project data. The first two researchers developed and conducted an interactive workshop as a design project intervention. The workshop was audio-recorded and relevant discussions were transcribed verbatim. Data analysis consisted of marking, coding and organizing the meeting minutes, transcription and other project documents. All three researchers regularly convened to reflect and discuss the different types of knowledge generated during the study.

The results point to new opportunities for understanding and solving circularity challenges. Following the action research approach, it was identified that the project team had high ambitions. Translating those into actual circular design solutions nevertheless turned out to be challenging. A Circular Project Model was therefore developed by the first researcher to provide insight into (a transition to) circular construction (Figure I). The Circular Project Model was implemented during a circularity workshop at the architectural firm's office. This workshop resulted in an overview of linear and circular material flows, and the possibilities and impossibilities for change. The overview of material flows and the associated circularity challenges led to new knowledge for practice and science. Some of the knowledge was subsequently implemented during the focal design project. Ideas proposed during the workshop include: assessing reuse potentials of materials in buildings; designing with future disassembly and reuse in mind; and promoting commitment among clients and other stakeholders for circular design. Researchers can further build on these suggested opportunities by developing new circularity solutions and refining the model. Practitioners can use the presented insights to systematically rethink their common design practices. 


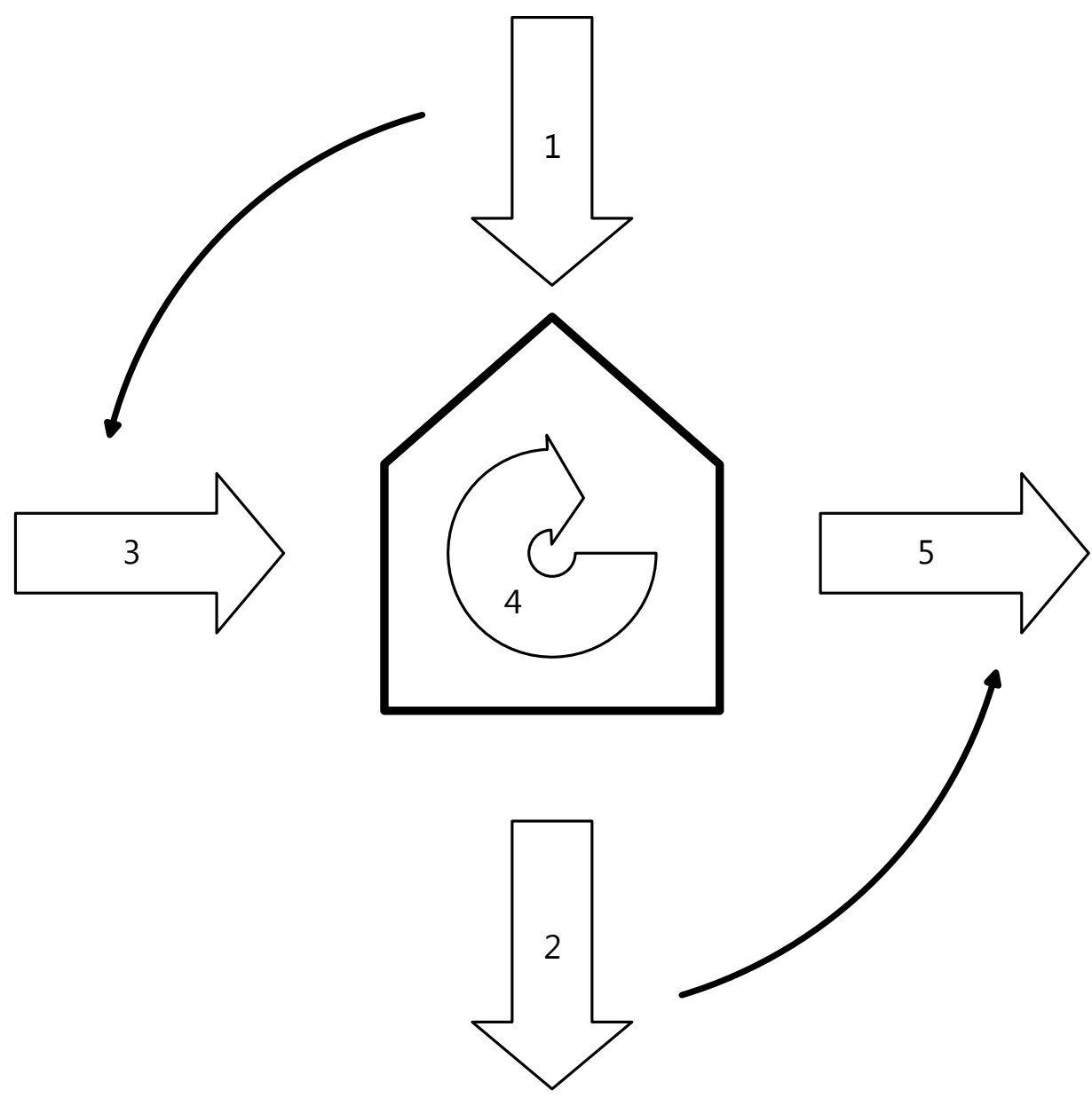

Figure I: Circular Project Model with thick arrows representing material flows: $1=$ new; $2=$ waste; $3=$ reuse (towards a focal site); $4=$ reuse (on a focal site); $5=$ reuse (from a focal site). Thin arrows represent a transition from linear to circular practices

Researchers: Marc van den Berg, Hans Voordijk \& Arjen Adriaanse

\section{II: Relative learning benefits of serious games for construction supply chain management}

This (completed) study developed a high-tech serious game variant of the construction supply chain management serious game presented in Chapter 6. An exploratory experiment with $43 \mathrm{PhD}$ candidates was thereafter conducted to assess the relative learning benefits of both low-tech and high-tech variants. The

II: Relative learning benefits of serious games for construction supply chain management | 231 
resulting paper was presented at the $27^{\text {th }}$ Annual IPSERA Conference 2018, Athens.

Serious games offer their users an experience that is planned to be meaningful yet have rarely been used for construction-related supply chain education. Depending on the technology used to design such an experience, two (main) types of serious games can be distinguished: low-tech and high-tech games. We use the term low-tech to refer to a subset of games in which the simulated environment is represented using analogue methods (e.g. board games), whereas we use the term high-tech to refer to games that use digital methods (e.g. video games). Both low-tech and high-tech serious games can represent the same environment. In order to select one of these two types, researchers, educators and game designers need to understand what the relative learning benefits of one type of game over the other are. This research sought to answer that question for the context of construction supply chain management by systematically comparing the reflections of players of both low-tech and hightech serious games for that domain.

A high-tech serious game was developed based on the low-tech serious game Tower of Infinity presented in Chapter 6 (Figure II). An exploratory experiment with both low-tech and high-tech variants was then conducted to study differences in players' perceptions. The experiment took place during a serious gaming workshop, which was a part of an Operations Research summer school for PhD candidates. During this serious gaming workshop, we collected data on learning benefits with a post-assessment survey - the most common assessment method (Bellotti et al., 2013). We assumed equivalence through randomization of the participants rather than pre-testing. This has the advantage of avoiding the threat to validity referred to as testing, since post-assessment results may be influenced by exposure to the same questions in a pre-assessment. Besides background information, the survey questions tried to assess learning benefits through a combination of recognized assessment methods: (i) game scores (a measure to evaluate whether the player was successful in the game), (ii) supply chain optimization strategies deployed (a measure based on earlier operationalizations of the learning objectives (Van den Berg, Voordijk, Adriaanse, \& Hartmann, 2017)) and (iii) personal views (a measure focused on the game's perceived effectiveness). Data analysis consisted of systematically comparing the data collected from both low-tech and high-tech groups. Assuming that the data are approximately normally distributed and have equal variances, we evaluated the learning differences between low-tech and high-tech participants with a twotailed t-test $(\alpha=0.05)$. Based on these evaluations, we drew conclusions on the learning benefits that one type of game has over the other. 
Based on the results presented in this study, we conclude that the learning benefits of low-tech and high-tech serious games for construction supply chain management are comparable. Both variants of the serious game Tower of Infinity were played by two groups of (in total) $43 \mathrm{PhD}$ candidates during a serious gaming workshop. It was found that learning benefits (only) differ for people playing a low-tech or high-tech game in 'making trade-offs in response to manufacturing delays' (favoring the high-tech game players). We also conclude that high-tech game players expect low-tech games to be more 'fun' and that low-tech game players expect high-tech games to be more 'realistic'. No other differences were found between low-tech and high-tech serious game usages, from which we suggest that the game mechanics led to similar responses rather than the game technologies deployed. More experimental research with people from different backgrounds can further strengthen these conclusions. We hope that our insights on the relative learning benefits of low-tech and high-tech serious games for construction supply chain management help other researchers, educators and game designers in selecting the most appropriate serious game technologies for their needs.

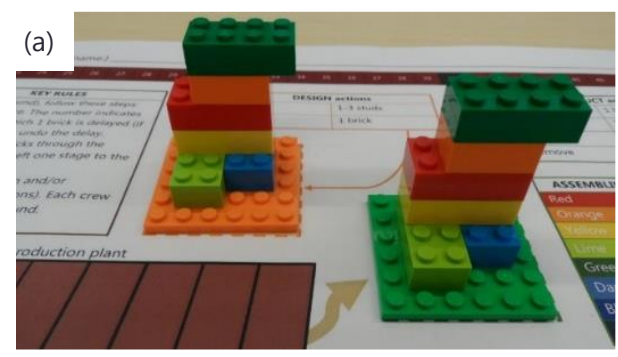

(b)

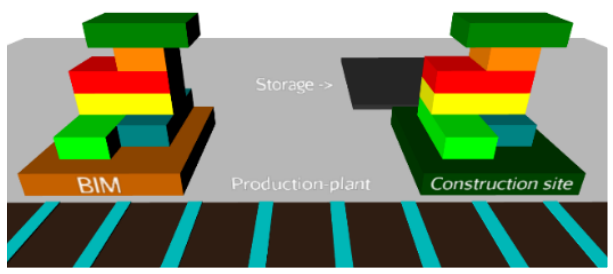

Figure II: Prototypes of the serious game Tower of Infinity for construction-related supply chain education: (a) low-tech and (b) high-tech variants

Researchers: Marc van den Berg, Alexandr Vasenev, Hans Voordijk \& Arjen Adriaanse

\section{III: Designing Things to explore controversies}

This multiple-case study (put on hold) reflected on three participatory design projects that were conducted as part of a master course. The projects explored societal controversies through designing 'Things' (conceptualized as sociomaterial assemblies) instead of 'objects'. A cross-case analysis revealed that Things can engage humans and non-humans with exploring controversies. 
Designers are increasingly interested in dealing with social issues for which 'something must be done', such as radioactive waste, high-voltage lines or air pollution (Callon, Lascoumes, \& Barthe, 2009; Schoffelen et al., 2015; Venturini, Ricci, Mauri, Kimbell, \& Meunier, 2015). These issues are inherently uncertain and dynamic, consisting of many intertwined aspects that are not easily understood or resolved. For such issues, participatory design and Actor Network Theory scholars have advocated an alternative for the rational problem-solving approach that is dominant in product development (Emilson, 2014; Murray, Caulier-Grice, \& Mulgan, 2010). Starting from the standpoint that those affected by a design should have a say in the design process, participatory design focuses on aligning both human and non-human resources to move an emerging object of design forward (Björgvinsson, Ehn, \& Hillgren, 2012; Ehn, 2008; Ehn et al., 1996). Methodologically, the approach is based on involving a plurality of actors (giving a voice to the 'weaker'), building long-term relationships and performing early prototyping to explore possibilities (Emilson, 2014, p. 19). For ANT scholars, social issues belong to their respective actors and, since each actor has her/his own perspective, social issues are framed as multi-sided controversies rather than single-sided problems (Latour, 2005b, 2008; Venturini, 2010). Instead of 'solving' those controversies, designers can assist here in 'exploring' how to deal with the controversy at hand through bringing diverging viewpoints together (Venturini et al., 2015). The design product in this controversy-exploring approach is not an object but a 'Thing', conceptualized by Latour (2005a) as a socio-material assembly: human and non-human collectives through whom controversies are addressed by initiating collective action. The conceptual links between participatory design, ANT and related social sciences have been discussed in length (Storni, Binder, Linde, \& Stuedahl, 2015), but the practical implications of designing from these perspectives remain less understood.

To provide reflective evidence on designing Things, this study adopted a multiple-case study methodology. Since design projects and social issues emerge in situations where researchers have little control, a multiple-case study method (Eisenhardt, 1989; Yin, 2009) was selected to acquire an in-depth understanding about the practice of designing Things. This study includes three cases of participatory design projects for comparison and discussion (Figure III). The first case covers the organization of an uncomfortable social event to explore cultural clashes between European and Asian students at a Dutch university. The second case dealt with the creation of a so-called 'Wall of Restitution' to explore the impacts of earthquakes caused by gas extraction in the North of the Netherlands. The third case is about an occupation to explore the (then) rather limited use of a Dutch university's research and fabrication laboratory (makerspace). Detailed insights of these three design projects were acquired 
through active participant observations, reviewing student reports and reflective group discussions among the researchers.

The study provided practical affirmation that Things can engage humans and non-humans with exploring controversies. In a context where design students are trained to solve problems, the Thing concept assisted (and provoked) these students to realize that design can be relevant to society in other ways than solving technical problems. As expected from literature (Binder et al., 2011; Björgvinsson et al., 2012), the Things continuously flickered between the materiality and the sociality as well as between 'parliamentary' and 'laboratory' practices. However, the concept turned out to be difficult to put to work: students initially approached the Thing as a 'solution' to a 'problem'. The three cases also point out that provocative Things can increase social engagement. The researchers argue that, even though students took on different roles in exploring the controversies, all student groups strived for connecting humans and nonhumans involved with the controversy. This ability to engage with non-humans as well as with humans seems to be a key aspect of the emerging designerly approach to deal with controversies.
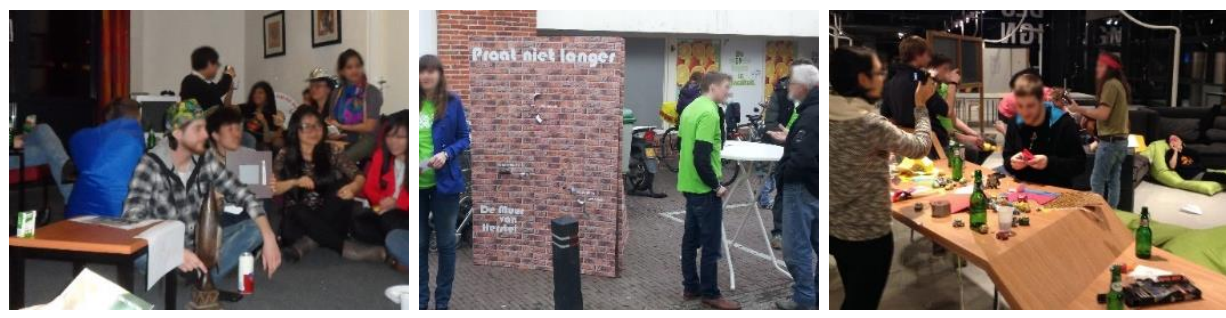

Figure III: Impression of three participatory design projects with humans and non-humans interacting with each other

Researchers: Marc van den Berg, Robert-Jan den Haan, Frederick van Amstel, Timo Hartmann \& Mascha van der Voort

\section{IV: BIM solutions for integrated project management of reversible buildings}

These four smaller (completed) studies developed technical BIM solutions for several construction management problems in circular building projects. The projects were conducted by master's students from Egypt that I co-supervised (though never officially) and/or collaborated with. They are presented in order of my involvement, starting with the one in which I was involved most.

IV: BIM solutions for integrated project management of reversible buildings | 235 
The first research project concerns the development of a software framework that evaluates the transformation capacity of a conceptual building design. The transformation capacity is a measure that indicates the ability of a building to deal with functional, technical or physical changes without generating material waste. Buildings with a higher transformation capacity can deal better with changing use patterns or technical requirements than buildings with a lower score. Previous studies (e.g. Durmisevic, 2006) described criteria that influence the transformation capacity and proposed models to assess a design proposal accordingly. This project tried to explore how designers could be informed about the transformation capacity. To that end, we conducted a semi-structured interview with a Dutch architect (and I later transcribed this) to better understand the building design process. Focused on the conceptual design stage, the student researcher then developed a prototypical framework. The prototype could be interacted with through a button in non-parametric architectural design software (SketchUp). This would assess (a few criteria of) the transformation capacity of the 3D design model and provide both textual (numerical scores) and visual (colors) feedback. For reasons of efficiency and modularity, the software architecture of the prototype distinguished between four layers: integration, preparation, manipulation and visualization. We presented a working prototype (Figure IV) during a research project meeting with 15 participants. Their feedback was collected and could be used to further develop the software (which was out of this thesis' scope).

The second project proposed to evaluate demolition processes using pullplanning and BIM. A literature review into reverse logistics in construction was firstly conducted. Based on this, the concept of selective dismantling based on customer needs was further examined as an alternative demolition method. The project explored how demolition processes could be optimized with a BIM-based pull-planning system. As such, we conducted a semi-structured interview with a project leader of a Dutch system builder to better understand assembly and disassembly processes. This interview was complemented with a visit to a largescale demolition project. The student researcher later assessed the practicality of pull-planning criteria for selective demolition and developed a framework to demonstrate how the recovery of salvaged building elements could be optimized.

The third and fourth project related reversible building design with BIM-based project management tools respectively geographic information systems (GIS). For the first of these two projects, the research student linked a parametric model of both a (real-world) timber façade frame and a metal façade frame with estimated time and cost data to create a $4 \mathrm{D}$ respectively $5 \mathrm{D}$ model. The project concluded with reflections on the potentials of existing BIM tools for reversible 236 | Appendix II: Complementary research work 
design challenges. The last research project examined how the deconstruction of a reversible building could be visualized and simulated with GIS. Instead of using GIS to model reverse logistics on an urban level, the student researcher proposed the rather innovative idea to use it for indoor movements of deconstructed building elements. Based on geometric information of modeled objects and a path-finding algorithm, the student demonstrated whether or not any objects blocked the disassembly and movement of any focal objects. This provides new ways to inform design or demolition managers about the disassemble-ability of a building.
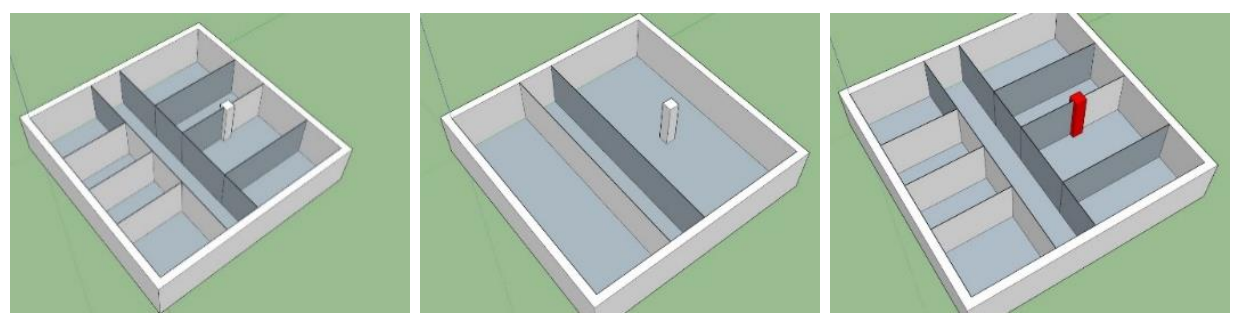

Figure IV: Screenshots of a proof-of-concept. A particular (fixed) column limits the possibilities for transformations; the software framework provides feedback through coloring it red

Research students (in order of above projects): Usama Atteya, Ahmed Elmaraghy, Ahmed Shawky \& Ahmed Rashad 


\section{Appendix III: PhD research Timeline}

This appendix provides a visual timeline of key research interests, project meetings, scientific conferences, professional courses, workshop sessions and co-supervised students that all contributed to this PhD research.

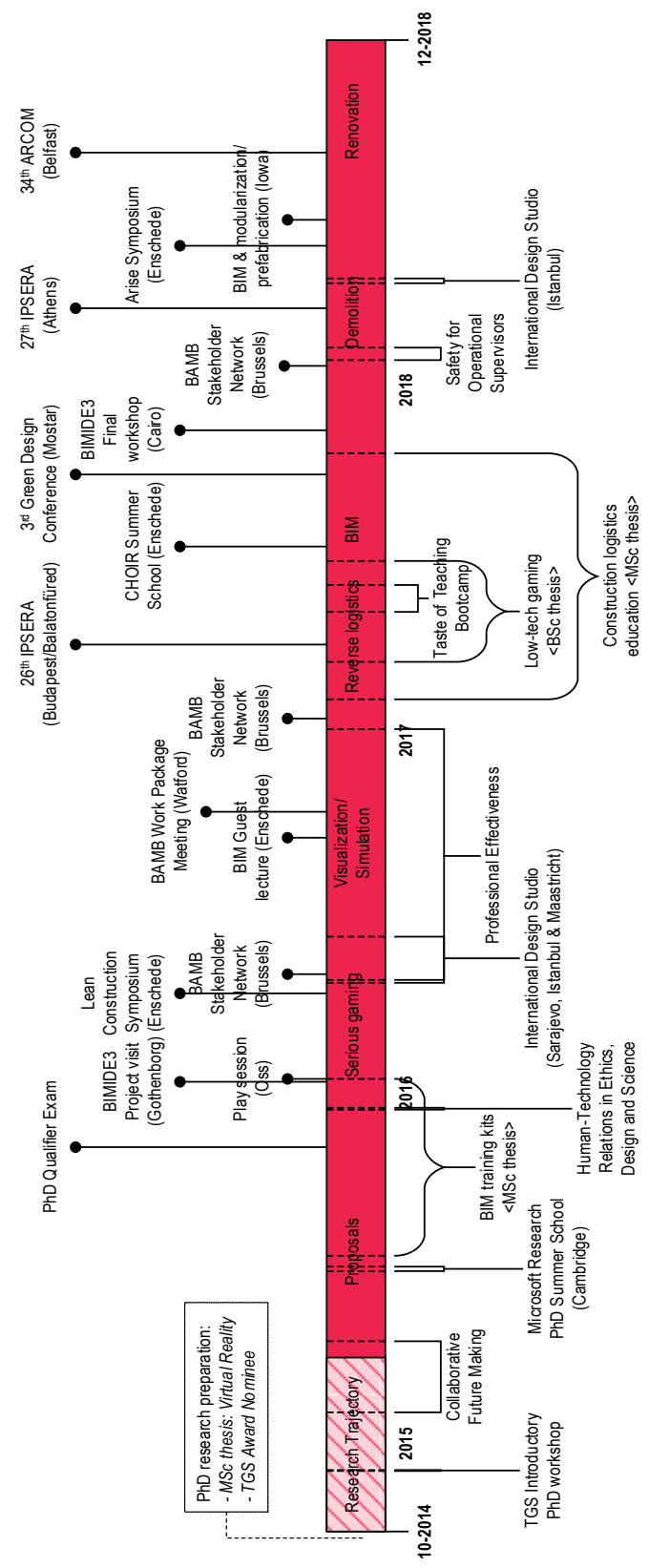




\section{Glossary}

Building Information Modeling - A methodology, accompanied with processes and techniques, that aims to represent, store and manage essential building design and project data in digital format over a building's life-cycle.

Circular economy - An industrial system that is regenerative by intention and design through decoupling resource depletion and economic growth. Proposed alternative for the linear economy.

Cradle-to-cradle - A framework to design production processes in which materials flow in closed-loop cycles.

Destruction - Process of turning material into waste, which may or may not be recycled.

Information - Data which are relevant, accurate, timely and concise.

Linear economy - An industrial system that follows a 'take-make-dispose' model of resource consumption.

Object - Any physical part of a building that can be handled separately.

Recovery - Process of collecting material with the aim to substitute virgin materials in construction. Always precedes reuse.

Recycling - Process in which material is reprocessed into raw material that can serve as inputs for new products.

Reduce - Process of decreasing the use of materials.

Reuse - Process in which material is used for a similar purpose without significantly changing the physical form of the material.

Reversible building - A type of building that is specifically designed to enable transformations, disassembly and reuse of building objects.

Waste hierarchy - An order of prevalence for different end-of-life strategies. 


\section{Acknowledgements}

When the lights go out / And you throw yourself about in the darkness where you learn to see / When the lights go out / Don't you ever doubt / The light that we can really be

U2, The Blackout

For a long time, I was unsure if I would be able to complete any PhD thesis. There was basically no suitable PhD position open when I was ready to throw myself in the darkness. I could nevertheless start a six-month research trajectory thanks to a personal bridging grant. Additional funding then gradually followed in the subsequent years. As such, I worked on three more projects, which all had their own specific deliverables, stakeholders and expectations. They offered me great opportunities to continue my PhD research journey. But also to doubt about where that journey would actually take me. Luckily, there were many wonderful people who helped me learn to see in the darkness. Some people even switched on some lights and brightened my journey. I owe them my gratitude.

I want to start with thanking dr. Elma Durmisevic. You inspired me to focus on one of the biggest challenges the construction industry faces in this century: the transition towards a circular built environment. The BAMB research project, and in particular your leading role in it, have helped me to understand the importance as well as the complexities involved in that transition. You have been advocating 'circular' design practices well before the term got popular. You are also excellent in bringing key parties together to discuss and disseminate research findings. I could benefit from that by getting to know many other inspirational people here in the Netherlands and abroad. Even though we had to change our initial plans to develop a 'virtual simulator', I am thankful for the opportunities you gave me over the past few years.

The first person with an official role in this $\mathrm{PhD}$ trajectory is my promotor prof. Arjen Adriaanse. We met quite some time ago when I kindly declined an offer for a PDEng position. I am very happy that you later dared to reallocate the funding to a research position for me and, for the first time, gave me some hope that I could actually complete a PhD. While you have a very busy agenda, you were always prepared to make time available for me - even during your holidays. You have a great eye for detail, but also helped me a lot in trying to find the common threads between the distinct papers of this thesis. Your personal touch to supervision and friendly messages with intermediate achievements furthermore made it a pleasure to work with you.

The next person whom I want to thank abundantly is my other promotor dr. Hans Voordijk. You have similarly played a key role in making my $\mathrm{PhD}$ research 
possible in the first place through combining different research budgets (and pulling some strings behind the scenes). During these years, you helped me a lot with quick and constructive feedback on all kinds of papers and reports. I really like it that you have always done this with a down-to-earth approach and a very positive mindset. This helped me to deal with inevitable disappointments along the way. It is also really impressive how you know to maneuver through bureaucracy and get things done. That almost looks like politics. It was also fun to join you on several trips to meetings and conferences abroad.

Other (former) colleagues have also really stuck their neck out for me. While he is a member of the opposition, prof. Timo Hartmann has helped me a great deal at the very start of this PhD trajectory (when I was still very much in the darkness) through encouraging me to pursue this trajectory and teaching me some essential academic skills. Dr. Robin de Graaf has helped me a lot with one of the chapters (and continues to do so in integrating the work with the Systems Engineering method). As head of the department, prof. André Doree did not only express his faith in me during several (unconventional) decisions about my academic career, but also managed to maintain a nice and pleasant working environment in the office. The dean, prof. Geert Dewulf, did so at a faculty level and helped me with preparing the proposal that got me awarded a bridging grant in the first place.

I continue with thanking the countless practitioners who shared their invaluable knowledge with me. There are many persons from several companies who agreed to have interviews with me, sent me project documentation, gave me ideas during workshops or demonstrated practices on site. Here, I can only mention a few who had an extraordinary impact. Special thanks first go to Adam Duivenvoorden of De Groot Vroomshoop: you had an absolute key contribution in this work through (always enthusiastically) explaining about your company's building system on several occasions, sharing a lot of project data when I needed it and connecting me with many other people (including your partner for demolition works). I also want to thank the people of the Hein Heun Groep who became my co-workers for a couple of months. In particular, I thank Jonnie and Sander: it has been a great experience to work with and learn from you. I had some good laughs at the site office and truly enjoyed our discussions on the differences between 'theory' and 'practice'. I am furthermore very grateful to Esther Bleumink of bct architecten, ingenieurs en adviseurs. It is great to see how you pursue sustainability and circularity in your projects. Thank you for providing me access to one of them and collaborating in exploring new ideas and methods.

I am very grateful to prof. Charles Jahren and his wife Jeane for helping me to broaden my horizon and welcoming me in Iowa. You have been tremendously 
kind to let me stay in your house, introduce me to others and organize several activities (the most memorable being our bike trip and winery visit). I also thank Larry W. Cormicle, who organized and joined me on several insightful visits to construction firms in Iowa. I learned a lot from you about (local) construction management practices and educational philosophies. Even though my trip to Iowa did not result in a follow-up study (yet), the experience meant a lot for me.

There were also many nice colleagues who indirectly contributed to this work. I thank Yolanda Bosch and Jacqueline Nijhof for helping out with all kinds of administrative matters. Many fellow PhD and PDEng candidates brought life to the 'aquarium' and shared their wisdom (or jokes) with me. Thanks to all for the nice time. Some even joined me on trips to conferences, others to local bars and restaurants. Léon, Bart and Ramon did both. It was a great pleasure to share ideas and work with Pieter Beurskens and Patrick de Laat (and to go on many wonderful trips together). I am very happy to become friends with the 'Doctors of Surprise'. They are indeed full of surprises (but the returning discussion on the meaning of life is not one of them). I thoroughly enjoyed our trips to Hamburg, Warsaw and Bruges. Frederick bamboozled like no other and made me excited to try and experiment with new design techniques. With Robert Jan, I have been working on a side (a.k.a. hobby) research project that I hope we can once finish. Camilo, Pinnie and Denis were often up for a dinner or night out together. Special thanks go to Ruth, who has always shared positive vibes, helped with proofreading, joined on many trips and kept reminding me to cross the bridge when I would get there.

Many other people supported me simply by being good friends. A shout-out to Thibats friends, especially for the many board game nights (thanks Wesley and Celestine), the excellent meals at busy times (thanks Martijn), the wonderful Denmark trips (thanks Mette and travel companions), the regular reunions (thanks 'Oude Lullen') and, of course, the trainings that I still enjoy (thanks Hans). I am also grateful for the lifelong memories I share with my study friends (thanks Team Twente), Kick-In related friends (thanks KIC11 and whiskey evening men), faraway friends (thanks Ana Patricia), high school friends (thanks TAK) and flat mate friends (thanks Bevers).

I end here with thanking my dear family. Remco and Erwin helped me sometimes to free my mind and celebrate the milestones, but, more importantly, are always there to fall back on. I am finally immensely grateful to my parents for their love, advice and support. Your life lessons and encouragements are invaluable. Thank you!

Marc van den Berg 242 | Acknowledgements 


\section{About the author}

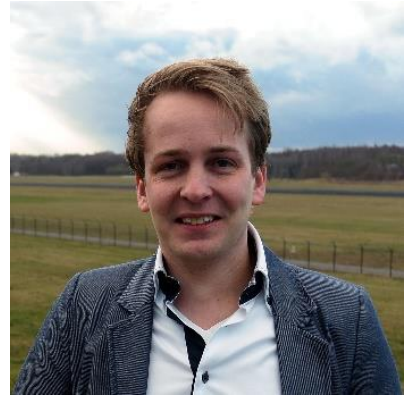

Marc van den Berg was born and raised in Zwolle, The Netherlands. In 2007, he moved to Enschede to study Civil Engineering at the University of Twente, unaware that he would stay there for over a decade (and counting). After receiving his bachelor's degree (cum laude) in 2010, he organized the university's introduction period for new students (Kick-In 2011) and joined a study tour to Singapore and Indonesia. He followed the Construction Management \& Engineering master's program and received his degree (cum laude) in 2014. Thanks to a bridging grant, he could then start a research trajectory that eventually culminated into a PhD trajectory. During that period, he was also a mentor and tutor of Civil Engineering freshmen students, conducted workshops and supervised several graduation projects. He continues his academic career at the University of Twente as assistant professor in Systems Engineering. 


Buildings are typically designed as permanent structures, but quickly demolished when no longer needed. This causes enormous socioenvironmental problems that are becoming increasingly visible. Material reduce, reuse and recycle activities are thus becoming both an obvious and imperative objective. This $\mathrm{PhD}$ thesis examines the management of such activities as information challenges. It integrates six demolition and design management studies that, altogether, result into two key strategies for closing material loops and moving towards a circular built environment. 